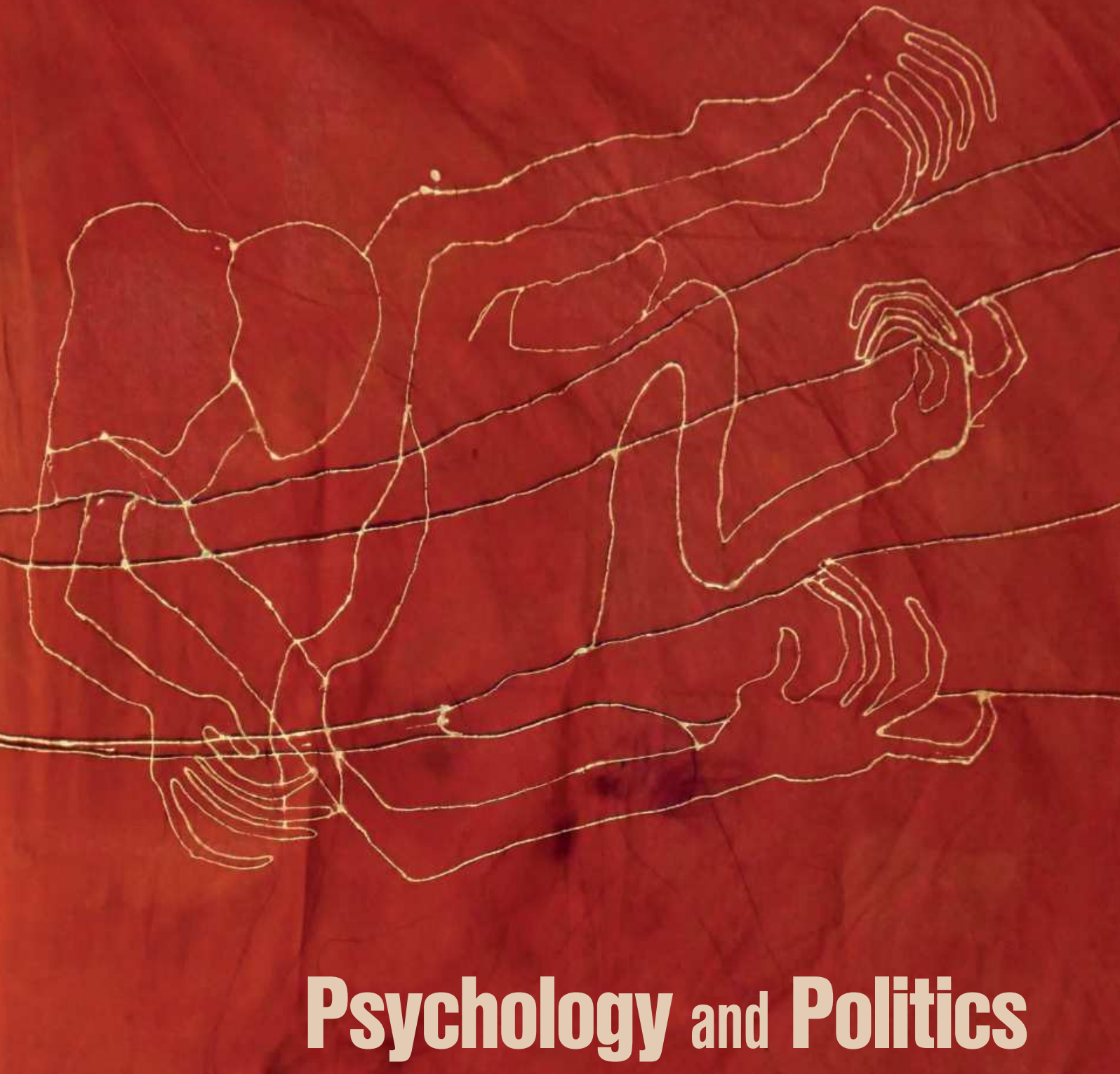

Intersections of Science and Ideology in the History of Psy-Sciences

Edited by Anna Borgos, Ferenc Erős, and Júlia Gyimesi 


\section{PSYCHOLOGY AND POLITICS}





\title{
Psychology and Politics
}

Intersections of Science and Ideology in the History of Psy-Sciences

\author{
Edited by \\ Anna Borgos \\ FERENC ERŐS \\ and \\ Júlia Gyimesi
}

"'CEU PRESS

Central European University Press

Budapest-New York 
Copyright (C) the editors and contributors 2019

\author{
Published in 2019 by \\ Central European University Press \\ Nádor utca 11, H-1051 Budapest, Hungary \\ Tel: +36-1-327-3138 or 327-3000 \\ E-mail: ceupress@press.ceu.edu \\ Website: www.ceupress.com
}

\begin{abstract}
All rights reserved. No part of this publication may be reproduced, stored in a retrieval system, or transmitted, in any form or by any means, without the permission of the Publisher.

The book was supported by the National Research, Development and Innovation Office of Hungary (project nr. K-124192).
\end{abstract}

ISBN 9789633863121

Library of Congress Control Number: 2018945713

Names: Borgos, Anna, editor. | Erős, Ferenc, editor. | Gyimesi, Júlia, editor.

Title: Psychology and politics : intersections of science and ideology in the history of psysciences / edited by Anna Borgos, Ferenc Erős, and Júlia Gyimesi.

Description: Budapest ; New York : Central European University Press, 2019. | Includes bibliographical references and index. | "The present volume is based on the papers presented originally at the conference held in Budapest in October 2015 under the title Psycho-Politics: The Cross-Sections of Science and Ideology in the History of Psy-Sciences"-Introduction.

Identifiers: LCCN 2018057538 | ISBN 9789633863121 (hardcover)

Subjects: LCSH: Political psychology-Europe, Eastern-Congresses.

Classification: LCC JA74.5 .P78 2019| DDC 320.01/9-dc23 LC record available at https://lccn.loc.gov/2018057538 


\section{Table of Contents}

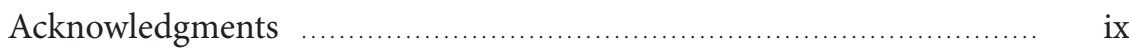

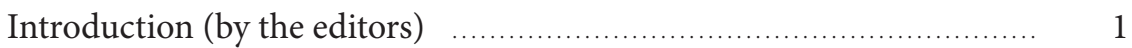

I. CULTURAL REPRESENTATIONS OF PSYCHOANALYSIS IN PERSONAL AND SOCIAL HISTORY

"A Museum of Human Excrement"

Michael Molnar

Anomalies of Demarcation in Light of the Nineteenth-Century Occult Revival

Júlia Gyimesi

Psychoanalysis in Representative Organs of the Hungarian Press between 1913 and 1939

Melinda Friedrich

Alice Bálint at the Intersection of the Personal, the Professional, and the Political Anna Borgos

\section{FERENCZI AND RÓHEIM REVISITED}

Violence, Trauma, and Hypocrisy

Ferenc Erös 
Sándor Ferenczi's Epistemologies and Their Politics: On Utraquism and the Analogical Method

Raluca Soreanu

“Tell Them That We Are Not Like Wild Kangaroos": Géza Róheim and the (Fully) Human Primitive

Shaul Bar-Haim

Géza Róheim: Alienness as a Source of Political Attitude

György Péter Hárs

III. PSYCHOANALYSIS AND PSY-KNOWLEDGE IN SOFT AND HARD DICTATORSHIPS

Psychoanalysis in Troubled Times: Conformism or Resistance?

Stephen Frosh

Psychoanalysis and Taking Sides: Two Moments in the History of the Psychoanalytic Movement

Julia Borossa

How Ideology Shaped Psychology in Times of Wars and after Wars

Gordana Jovanović

The Social Roles and Positions of the Hungarian Psychologist-

Intelligentsia between 1945 and the 1970s: A Case Study of Hungarian Child Psychology

Melinda Kovai

Remembering the Reinstatement of Hungarian Psychology in the

Kádár Era: Reconstructing Psychology through Interviews

Dóra Máriási

IV. THE POLITICS OF PSYCHIATRY—BODIES, ILLNESSES, AND MENTAL HEALTH

The Hygiene of Everyday Life and the Politics of Turn-of-the-Century Psychiatric Expertise in Hungary

Emese Lafferton

Who Is Mentally Ill? Psychiatry and the Individual in Interwar Germany Zsuzsanna Agora and Virág Rab 
Russian Psychiatry beyond Foucault: Violence, Humanism, and Psychiatric Power in the Russian Empire at the End of the Nineteenth and Early Twentieth Century

Ruslan Mitrofanov

Patients and Observers: Specific Data Collection Methods in an Interwar Transylvanian Hospital

Zsuzsa Bokor

Contemporary Criticism and Defenses of Psychiatry's Moral-Medical Kinds in Light of Foucault's Lectures on the Abnormal

Balázs Berkovits

\section{CRITICAL PSYCHOLOGY AND THE EPISTEMOLOGY OF PSY-KNOWLEDGE}

Neoliberal Governmentality, Austerity, and Psycho-Politics

Philip Thomas

Psycho-Politics and Illness Constructions in the Background of the Trauma-Concept of the DSM-5

Márta Csabai and Orsolya Papp-Zipernovszky

Is Integration Possible for Psychoanalysis?

Aleksandar Dimitrijević

Parallels, Intersections, and Clashes: Journeys through the Fringes

Dennis Fox

About the Authors

Index of Names 



\section{Introduction}

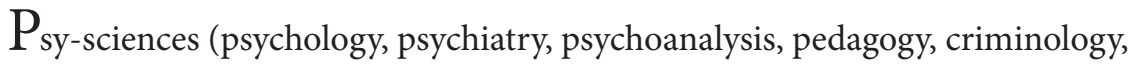
special education, etc.) have been connected to politics in diverse ways during the twentieth and twenty-first centuries. This relationship manifests itself either through direct political pressure or through more general and subtle interactions between cultural and social processes and scientific currents and practices. The book collects ideas and findings on the history and politics of psy-sciences including scientific and theoretical discourses, institutions, and professionals. This volume will allow us to compare the development of the psy-sciences and the institutions in which they are practiced in Eastern European with developments in other regions.

Concerning the history of these disciplines, demarcations and shifts instigated by power relations can be found within scientific movements and schools in the field of psychology, psychiatry, and psychoanalysis. But when closely investigated, politics can also be grasped in the epistemology of psysciences and in the governmental practices based on them. Human relations, emotions, everyday ethical principles, etc. have become conceivable in psychological terms, thus giving way to practices of normalization, as well as their utilization and manipulation by political decision-makers and diverse institutions. What is the form and dissemination of certain regimes of truth as they are reformed and as they become the center of old and new ideological struggles? What are the historical-political processes that influence the fields of psy-knowledge, inducing transformations of professional perceptions of the 
subject and normality, while, at the same time, determining the very position of scientific trends and professionals?

The present volume is based on the papers originally presented at a conference held in Budapest in October 2015 under the title "Psycho-Politics: The Cross-Sections of Science and Ideology in the History of Psy-Sciences." The aim of the conference was to bring together scholars and researchers interested in the social, cultural, and political history, and the present status of "psy" disciplines, the sciences of the subject (Rose 1996, 1999), from a critical point of view and especially in the lesser-known Central and Eastern European context. The idea of the conference arose from the work of our research group, ${ }^{1}$ which focuses on the history and politics of the psy-sciences in Hungary.

Besides exploring the abovementioned questions, the volume makes a significant contribution to the history of psychology in general and psychoanalysis in particular. Most of the essays focus on specific historical issues, revealing not only as yet unknown aspects of the history of psy-sciences, but also analyzing and re-interpreting the evolution of certain domains of psychological theory and practice. Due to this analytical-historical attitude, on the one hand, the authors of the volume call attention to several previously neglected or ignored cultural, social, political, and scientific influences that have shaped contemporary psychological knowledge. On the other hand, the volume provides rich materials based on primary research in and beyond psychology; recently unearthed archival materials, letters, public papers, lectures, and interviews are examined here. When conjoined with the attitudes of critical psychology, the essays contribute to research on the history of psychological knowledge in a thought-provoking way.

Sections one and two of our book deal primarily with psychoanalysis as one of the historically most influential disciplines within psy-sciences.

1 The research team was formed within the Social and Cultural Psychology Group of the Institute of Cognitive Neuroscience and Psychology of the Hungarian Academy of Sciences. The team was headed by Anna Borgos and its members included Balázs Berkovits, Ferenc Erős, Melinda Friedrich, Júlia Gyimesi, Melinda Kovai, and Dóra Máriási. The research was funded by the Hungarian National Scientific Research Fund (OTKA) between 2013 and 2017. The history of our research group goes back to the late 2000s, when the editors of the present volume, in collaboration with other colleagues, began their systematic explorations into the history of Hungarian psychoanalysis, as well as delved into the methodological and epistemological questions, gender issues, and cultural and political aspects related to it. (See Erős, Lénárd, and Bókay 2008; Borgos 2017; Erős 2012, 2017; Gyimesi 2015; Kovai 2016.) 
Although psychoanalysis in the recent decades seems to have lost its onetime distinguished role within the therapeutic field, nowadays we observe a growing scholarly interest in the examination of its cultural and social history as well as its specific methodological and epistemological questions. Recent publications (e.g., Makari 2008; Frosh 1999; Zaretsky 2005; 2017; Roudinesco 2014; Herzog 2017; Whitebook 2017; Ryan 2017) broadly discuss the origins and the history of the philosophical, ideological, and political controversies over Freud's legacy. Psychoanalysis as critical social theory, the legacy of the Frankfurt School thinkers (Fromm, Adorno, Horkheimer, Marcuse) and Wilhelm Reich's contributions, has also received growing attention. Part and parcel of these developments, recent reinterpretations of Sándor Ferenczi's and Michael Bálint's concepts of trauma, Winnicottian object relation theory, and Lacanian psychoanalysis offer new understanding of present socio-political processes and problems such as repression, inequality, violence, hatred, prejudice, and social exclusion (Auestad 2012).

Our book provides an exploration of the changing representations of psychoanalysis in artistic, literary, and scientific discourses as well as its potential for understanding unconscious social and political processes. The essays in sections one and two illuminate some epistemological and historical questions related to the works of Sándor Ferenczi, Géza Róheim, Alice Bálint, and other representatives of the Budapest school of psychoanalysis, while also addressing numerous as yet unknown primary sources. By exploring several previously neglected aspects of psychoanalytic theory, the authors provide innovative and even provocative interpretations of the past and present-day significance of psychoanalytic thinking. The essay of Michael Molnar on the "museum of human excrement" illuminates thought-provoking conceptual problems in relation to the inner and public representations of psychoanalysis. Júlia Gyimesi’s essay points out the process of demarcation, that is, how psychoanalysts differentiated themselves from certain threatening spiritualistic, pseudo-scientific theories and practices, thus preserving the quasi-natural scientific framework of psychoanalysis. The work of Melinda Friedrich also contributes to research on the changing social representations of psychoanalysis by examining the process in significant organs of the Hungarian print media between 1913 and 1939. Anna Borgos's study, which interprets the recently discovered diaries of Alice Bálint, provides valuable insight into how personal and political changes affected her as a woman, a Jew, and a future analyst. Cultural embeddedness, boundary-work, general and scientific politics, intergroup relations play a central role in the work of the abovementioned authors. 
Ferenc Erős's essay, "Violence, Trauma, and Hypocrisy," approaches the relationship between politics and psychoanalysis more directly. He highlights Ferenczi's ideas on the potential parallel between psychoanalysis and liberal socialism. Raluca Soreanu explores Ferenczi's thoughts on his lesser-known concept of utraquism, calling attention to the theoretical significance of the concept and also pointing out its foundational role in establishing a hidden political vocabulary. The essays of Shaul Bar-Haim and György Péter Hárs highlight previously unknown aspects of the life and work of Géza Róheim, whose aim, citing Bar-Haim, was never to "humanize" the "primitive," "but to allow 'primitiveness' as a legitimate manifestation of the 'human.' Besides offering valuable insights into relatively unknown perspectives on and details of the history of psychoanalysis, these historical contributions also call attention to the manifold political connections of psychoanalytic theory and practice. Furthermore, these essays show why (and how) psychoanalysis, despite serious critiques, was able to survive and influence twentieth-century psychological thinking. As a theory deviating from the so-called academic mainstream, psychoanalysis was able to preserve a critical and open-minded attitude, which made some of its representatives unconventional, pioneering, and even rebellious. Thus, it is not surprising that the spirit of freedom fighters and revolutionists was not so far removed from representatives of psychoanalysis such as Ferenczi or Róheim. It was psychoanalysis itself that they could use as a tool of deviation. Moreover, interestingly, the epistemological and theoretical foundations of psychoanalysis made their deviation possible not only from so-called mainstream psychology/psychiatry, but also from classical forms of psychoanalytic thinking. Facing the many successful innovations in psychoanalysis, it seems that psychoanalysis as a theory is no longer as rigid and closed a system as its early representatives attempted to define it.

The essays in section three broaden the perspective by exploring the history of "psy" disciplines, including psychoanalysis, mainstream academic psychology, child psychology, etc., in various dictatorships and authoritarian regimes such as Nazi Germany, East European communist regimes, a LatinAmerican military dictatorship, and the South African apartheid regime. Together the papers show the role of ideology in shaping psychology's relationship to the existing social order and its role in legitimating and "normalizing" dictatorships. They also show how, after the failure of these regimes, processes of denial took shape in different periods.

Stephen Frosh explores two examples of the history of psychoanalysis in politically troubled times-during the National Socialist period in Germany 
and the 1970s military dictatorship in Brazil-to ask questions about psychoanalytic ethics, and the "psy"-professions' contribution to the legitimation of these regimes. Julia Borossa also raises the dilemma of the analyst's neutral stance versus his/her social responsibility as demonstrated during two historical moments-South Africa in the 1930s, Brazil in the 1970s-when the analyst might be pressured to take sides, even in a therapeutic setting. Gordana Jovanovićs study points out the ideological implications of the cognitive revolution for cultural psychology within the framework of social and cultural shifts in the second half of the century. Melinda Kovai, through the reconstruction of the destiny of Hungarian child psychology during the period of state socialism, shows how the historical and political situation of the country influenced the content of psychological knowledge. She also demonstrates how psychologists' professional identities changed because of a particular policy, which led to decisions that failed to take the links between individual and social problems into consideration. Relying on in-depth interviews with academic researchers and university professors of psychology during state socialism, specifically the Kádár era, Dóra Máriási explores the contestation over the relationship of psychology to power relations in the overpoliticized scientific field.

Section four focuses on the history of psychiatry, from a perspective largely influenced by Foucauldian concepts and analyses. The novelty of the essays in this section is that they collectively illuminate the "grey zone" of Eastern Europe's history of psychiatry. This topic has only recently become the subject of systematic studies (Marks and Savelli 2015). They also explain the ideological and political foundations of ideas concerning mental health and illness and the relationship between the body and mind in Russia, Hungary, post-war Transylvania, and Germany.

Emese Lafferton's study explains the involvement of turn-of-the-century psychiatry in solving social problems like alcoholism, prostitution, pauperism, and syphilis by highlighting the significance of (mental) health and prophylactics and by connecting these to both public discourses and social movements concerning these issues. Zsuzsanna Agora and Virág Rab explore German psychiatry in the early twentieth century, revealing the violent elements of an oppressive system through narrative accounts of Hungarian politician Loránt Hegedüs, who had been a patient in a Berlin sanatorium in the 1920s. Ruslan Mitrofanov reveals the progressive psychiatric treatments of the Kazan District Hospital in Russia around the turn of the twentieth century, critically reflecting on the generalizability of Foucault's approach. Zsuzsa 
Bokor's chapter investigates the work of Hungarian psychologist and physician Zoltán Bálint in the women's hospital located in the Transylvanian city of Cluj/Kolozsvár in the 1920s. Bálint collected extensive data on those of his patients who were prostitutes, which demonstrates both the special doctorpatient relationship and medicine's relationship to the female body through illness and sexuality. Balázs Berkovits explores contemporary ideas of the moral components of diagnoses and treatments, re-examining the forensic psychiatric cases provided by Foucault in his 1974-75 lectures on the abnormal (Foucault 2004).

The main topics of section five are related to critical psychology and the epistemology of "psy"-knowledge. Critical psychology is not a separate discipline or a field within the "psy" sciences, and it is not the opposite of what is called "positive psychology." Rather, it is a self-reflective activity (Parker 1995; Fox and Prilleltensky 1997), which stretches over the boundaries of mainstream academic psychology and produces a critical perspective on the social and historical context of psychological practice and theoretical concepts. Critical psychology tries to understand how academic, therapeutic, and everyday psychological knowledge is produced within the power relations of modern capitalist (market or state capitalist) societies. It has developed in connection to the most diverse "psy" disciplines, such as social psychology (Wexler 1983; Armistead 1974), experimental psychology (Holzkamp 1971), psychoanalysis (Jacoby 1975), psychotherapy (Parker 2015), and psychiatry (Ingleby 1981; Sedgwick 2015). The studies in section five present a broad and fresh overview of the current status of critical psychology and psychopolitics and provide a critical analysis of diagnostic practices.

Philip Thomas examines the relevance of Peter Sedgwick's and Foucault's work for resisting neoliberal austerity and introduces the work of the group "Recovery in the Bin," demonstrating how "psychocompulsion" ignores the roles that social and economic circumstances play in the ability to recover from mental health problems. The study by Márta Csabai and Orsolya PappZipernovszky investigates how the trauma concept behind the new diagnostic categories and symptoms described in the DSM-5 represents important social tendencies such as changes in the relationships between the body, gender roles, sexuality, and self-expression. Aleksandar Dimitrijević discusses the factors that have led to the current marginalization of psychoanalysis in relation to the prevalence of biological approaches and also contributed to its own inner disintegration. He simultaneously emphasizes the irreplaceable features of psychoanalysis and calls for its survival. Lastly, Dennis Fox explores approaches 
to communication and connection that have emerged from radical therapies including the human potential movement, Buddhist philosophy, and New Age consciousness, and their potential contribution to system-level criticism.

The broad scope of the essays produces a colorful portrait of the intersection of psy-sciences and politics and reflects on the past and the present of psychological and psychoanalytic thinking and on the questions of abnormality and deviance through the lens of power relations. By examining both Western and Eastern European developments, the reader can gain further insight into the specific interrelationship between science, politics, and the politics of science.

We would like to thank the following institutions and people for their help in realizing this volume: the National Research, Development, and Innovation Office, Central European University, the Institute of Cognitive Neurosciences and Psychology of the Research Center of Natural Sciences of the Hungarian Academy of Sciences, the Doctoral program in theoretical psychoanalysis at the University of Pécs, and professors Csaba Pléh, Samir Gandesha, and Antal Bókay.

The Editors

\section{REFERENCES}

Armistead, Nigel, ed. 1974. Reconstructing Social Psychology. Harmondsworth: Penguin Books.

Auestad, Lene, ed. 2012. Psychoanalysis and Politics: Exclusion and the Politics of Representation. London: Karnac.

Borgos, Anna. 2017. "Women in the History of Hungarian Psychoanalysis." European Yearbook of the History of Psychology 3: 155-80.

Erös, Ferenc. 2012. "Psychoanalysis behind Iron Curtains." In Psychoanalysis and Politics: Exclusion and the Politics of Representation, edited by Lene Auestad, 203-22. London: Karnac.

- 2017. "Ferenc Mérei and the Politics of Psychoanalysis in Hungary." In Traces of Violence and Freedom of Thought, edited by Lene Auestad and Amal Treacher Kabesh, 199-210. London: Palgrave Macmillan.

Foucault, Michel. 2004. Abnormal: Lectures at the College de France, 1974-1975. New York: Picador.

Fox, Dennis, and Isaac Prilleltensky, eds. 1997. Critical Psychology: An Introduction. London: Sage.

Frosh, Stephen. 1999. The Politics of Psychoanalysis: An Introduction to Freudian and Post-Freudian Psychology. London: Palgrave.

Gyimesi, Júlia. 2015. "Why 'Spiritism'?” International Journal of Psychoanalysis vol. 97, no. 2 : $357-83$. 
Herzog, Dagmar. 2017. Cold War Freud: Psychoanalysis in an Age of Catastrophes. Cambridge: Cambridge University Press.

Holzkamp, Klaus. 1971. Kritische Psychologie. Frankfurt: Fischer.

Ingleby, David, ed. 1981. Critical Psychiatry: The Politics of Mental Health. Harmondsworth: Penguin Books.

Jacoby, Russell. 1975. Social Amnesia: A Critique of Conformist Psychology from Adler to Laing. Boston: Beacon Press.

Kovai, Melinda. 2016. Lélektan és politika. Pszichotudományok a magyarországi államszocializmusban 1945-1970 [Psychology and politics: Psy-sciences in state socialist Hungary]. Budapest: L'Harmattan.

Lénárd, Kata, Ferenc Erős, and Antal Bókay, eds. 2008. Typus Budapestiensis. Tanulmányok a pszichoanalizis budapesti iskolájának történetéröl és hatásáról [Studies on the history and impact of the Budapest school of psychoanalysis]. Budapest: Thalassa.

Makari, George. 2008. Revolution in Mind: The Creation of Psychoanalysis. London: Duckworth.

Marks, Sarah, and Mat Savelli, eds. 2015. Psychiatry in Communist Europe. London: Palgrave.

Parker, Ian, ed. 2015. Handbook of Critical Psychology. London: Taylor and Francis.

Rose, Nikolas. 1996. Inventing Our Selves: Psychology, Power and Personhood. Cambridge, UK: Cambridge University Press.

- 1999. Governing the Soul: The Shaping of the Private Self. Second edition. London: Free Association Books.

Roudinesco, Élisabeth. 2016. Freud: In His Time and Ours. Boston, MA: Harvard University Press.

Ryan, Joanna. 2017. Class and Psychoanalysis. London: Routledge.

Sedgwick, Peter. 2015. Psycho Politics-Laing, Foucault, Goffman, Szasz and the Future of Mass Psychiatry. London: Unkant.

Wexler, Philip. 1983. Critical Social Psychology: Landscapes of Inequality. London: Routledge.

Whitebook, Joel. 2017. Freud: An Intellectual Biography. Cambridge, UK: Cambridge University Press.

Zaretsky, Eli. 2005. Secrets of the Soul: A Social and Cultural History of Psychoanalysis. New York: Vintage.

—. 2017. Political Freud: A History. New York: Columbia University Press. 
PART ONE

Cultural Representations of Psychoanalysis in Personal and Social History 



\title{
"A Museum of Human Excrement"
}

\author{
Michael Molnar
}

$\mathrm{O}_{\mathrm{n}}$ a table in the hall of the Freud Museum London stood a bell jar. It displayed, as I remember, some plants and twigs, the type of artificial habitat favored by Victorian taxidermists. But instead of the anticipated stuffed bird or animal, in the center on a bed of moss lay a small heap of excrement.

In 1988-89, Rachel Withers was artist-in-residence at the museum. Her assignment was to plan an exhibition based on Freud's life and work. In 1989 it was put on display, and it included that bell jar in the hall. Visitors invited to the exhibition were asked for their comments. Only one of them stuck in my memory and that was only because of the speaker's name-Dr. Couch. His comment was: "Miss Freud would not have allowed this in her house."

Dr. Couch was a psychoanalyst who worked at the Anna Freud Centre, across the road from the Freud Museum; he had been analyzed by Anna Freud herself, and the shadow of transference falls across his words. As well as expressing his own disapproval of the exhibition, his comment conjures up the previous occupants of the house (Anna Freud and, by implication and association, her father) as the phantom arbiters of the museum.

In fact I never met Dr. Couch, nor heard his remark (it was reported to me), and so I cannot tell whether it was serious or jocular, or even whether he was speaking of the bell jar alone or the entire exhibition. That is unimportant here. His sentence resounds like an oracle, and its echoes reflect something of the situation of the museum (its psychopolitical situation) and of my own experience there as an employee during the early years of its existence. 
People say funny things, and it is often hard to know why. Did Couch object on principle to allowing any artist into the museum to represent her view or version of psychoanalysis, or did he simply object to that one exhibit; that is, was it the excrement or art itself that he saw as scandalous? This specific uncertainty reflects our general uncertainty as employees of the museum responsible for representing Freud and his ideas to the public. We were still in the dark as to whether that responsibility could—or should—be delegated to artists.

While writing this chapter, I found myself questioning my own memory of Withers's exhibition. It took place twenty-six years ago, and perhaps I had misremembered that particular exhibit? I contacted her and, to my relief, she confirmed that what I had written about the bell jar was more or less accurate. But she corrected one detail. I had recalled the centerpiece as a pile of excrement. It was indeed, she replied, albeit a counterfeit made of polyfilla. But what I had forgotten was that this artistic heap of excrement was prettily gilded with gold paint.

It seemed that my memory had done exactly what I suspected Dr. Couch might have done: mentally substituted the thing itself for its representation. We were both literalists of the image, we had both denied the cultural transformation. By gilding the excrement Rachel was not just illustrating the traditional gold/shit equivalence; she was also, in effect, imitating the alchemy of the dream work as Freud interprets it, transforming the affect inspired by some possibly revolting object into its opposite, thus turning disgust into delight.

Withers' strategy - and the artist's task - was neatly formulated by Baudelaire: "You gave me your filth and I turned it into gold."

The museum that Couch visited that day was, evidently, no longer Miss Freud's house. However, visitors and media often assumed that some shadowy Freudian establishment (appointed perhaps by the International Psychoanalytical Association?) must be in charge. Confusion was understandable: the management structure baffled insiders almost as much as outsiders. The Sigmund Freud Archives Inc. in New York, a group of American psychoanalysts who controlled the Freud archives in the Library of Congress, were the designated trustees of the museum. But they lacked any financial resources, which actually came from a U.S. charitable organization, the New-Land Foundation.

\footnotetext{
1 “Tu m’as donné ta boue et j’en ai fait de l'or" (Charles Baudelaire, from "Projet d'épilogue pour la seconde édition des Fleurs du Mal.").
} 
Meanwhile the property itself was held by an English charitable trust. NewLand and Archives together set up a joint committee that met in New York, which in turn designated an Advisory Committee that met in London, to supervise the new museum.

This clunky chain of command allowed Richard Wells, the director at the time of the exhibition, a certain freedom. What permissions he sought (if any) or which of the committees (if any) he consulted remains unclear; what is clear is that he was cautious, for Rachel's exhibition was only opened to invited visitors on days when the museum was closed to the general public.

He had good reason for such caution. Nowadays museum artists-inresidence are common, but at the time this was a pioneering venture. Apart from that, the museum had been tainted with scandal from the outset, and it remained a potential target of media outrage. When it opened, the so-called "Freud Wars" were raging. These were polemics disputing the status of psychoanalysis, and the battleground was as much Freud's character as his theories. The museum itself was implicated in these wars. The Projects Director for Archives Inc., Jeffrey Masson, who was originally supposed to take charge of the future museum, had written articles questioning Freud's scientific and personal integrity. In 1984, he published a book entitled The Assault on Truth: Freud's Suppression of the Seduction Theory. Archives Inc. duly dismissed him three years before the museum opened.

Masson was a trained psychoanalyst: he was replaced by a professional curator, David Newlands. The fact that neither Newlands nor his successor Richard Wells (nor, for that matter, any of their staff) were psychoanalysts was one of the criticisms commonly leveled against the museum. This implied that only trained psychoanalysts are competent (or entitled?) to represent Freudian theory. This insidious idea caused a great deal of anxiety in the museum. Before the opening, Newlands was careful to submit his staff's exhibition drafts for vetting by a group of practicing analysts.

Was it a sort of corporate superego in the guise of the Freuds themselves that loomed over the directors and their staff? Couch's remark indicates that, in his eyes, it ought to have been so. And as Anna Freud's analysand, he might well have been confusing her person with the process of psychoanalytic training. If that were the case, the gist of his comment might be translated (and in this form be nearer the truth): it was not the phantasied Freuds but phantasms of the institutions of psychoanalysis that haunted the museum.

Whether actual members of the Institute of Psycho-Analysis perceived the museum as an infringement of a supposed monopoly on Freud is not the 
question. It is the perception of events from inside the museum that concerns me here, and for us the nexus of controversy and antagonism seemed to be visual representations of psychoanalytical theory. Accordingly, Couch's comment could well be interpreted as a criticism of attempts to transform those ideas into the alien idiom of art.

This hypothesis might seem devious. Surely it makes sense to attribute his reaction to a simple reflex of disgust at the bell jar's contents? After all, off-duty or on, a psychoanalyst is subject to cultural norms just like anyone else. But, at the same time, I assume he would have been capable of contextualizing a reference to anality. Everything depends on how the object is framed. I am led to assume that his objection was to such a graphic transformation of theory.

During her residency Withers was encouraged to discuss her exhibition project with the staff, and at some point Ivan Ward, who was in charge of the Education Programme, had suggested she should not overlook Freud's concept of the role of anality in human development. The hallucinatory construct under the bell jar and under discussion here was her response to that challenge. It could have been viewed as a botanical joke, or an aesthetic game, or a conceptual clash of registers. But in the House of Freud, or in the mind of a psychoanalyst (or in our perception of the analyst's attitude), it was seen as out of place, an irruption, an act of polymorphous mockery.

Psychopolitics hinges on perceptions, and perceptions of perceptions. We confront our own projections or introjections. Those phantasms seem to be our sense of attitudes emanating from institutions. But, however phantasmic, they emerge from a power relationship that produced real consequences.

There were, as I said, never any guidelines concerning how the museum should represent Freud and his work. The trustees, who could hire and fire, did not dictate its activities. The unease we felt about exhibitions can be attributed, on one level, to the inherent difficulty of the project, and on another, to bad weather in the psychoanalytic culture of the time (the Freud Wars, a siege mentality among analysts, evidence that the profession was in decline, financial uncertainties, etc.). All of this played a part. Couch seems only to have been voicing his own disgust. But his words hinted at a transferential identification, and that was the product of his psychoanalytic training. Whatever malaise afflicted us and the museum, it was historical and had its roots in the very origins of institutional psychoanalysis.

The botanical bell jar referred to those historical roots: a dream Freud dreamt in the summer of 1898 is diffracted through its lens. Writing it up in The Interpretation of Dreams, Freud prefaced his account with the words: "It 
is a short dream, which will fill every reader with disgust." The reason for that soon becomes evident-this is the "dream of the open-air closet." The account of the dream is brief enough to quote in full:

\begin{abstract}
A hill, on which there was something like an open-air closet: a very long seat with a large hole at the end of it. Its back edge was thickly covered with small heaps of faeces of all sizes and degrees of freshness. There were bushes behind the seat. I micturated on the seat; a long stream of urine washed everything clean; the lumps of faeces came away easily and fell into the opening. It was as though at the end there was still some left. (Freud [1898] 1953, 468-69)
\end{abstract}

But does it really fill every reader with disgust? In fact, the dream reader himself tells us he felt no disgust at all. On the contrary, the dream associations led him to delight, for the clotted closet turns out to be a replica of his couch and the gift of a grateful patient; hence a constant reminder for him of how much his patients honored him. He comments: "Indeed, even the museum of human excrement could be given an interpretation to rejoice my heart" (Freud [1898] 1953, 469).

At that time, psychoanalysis was hardly more than a name and a claim: it was propagated almost exclusively through the university lectures that Freud, as Privat Dozent, was entitled to deliver. Through the day's residues that its associations brought up, we find out that the dream deals with the aftermath of one of these university lectures.

The previous evening (in the lecture theater of Professor Krafft-Ebing, author of Psychopathia sexualis), Freud spoke about the connection between hysteria and perversions. This lecture, he states, "displeased him intensely." Furthermore, it being summer, he wished he was in the country with his family at Aussee, and he wrote: "I longed to be away from all this grubbing about in human dirt." Afterwards, a member of his audience told him that his theory of the neuroses had cleaned the Augean Stables of nineteenth-century psychology, and that he was, in effect, "a very great man." This praise only inspired a feeling of disgust in Freud, and as soon as he could, he escaped, went home, leafed through a couple of books (Rabelais and C.F. Meyer) and went to sleep.

The dream emerges as an expression of self-contempt overcome by selfconfidence. A gargantuan exuberance sweeps aside both distaste for patients and their pathology ("human dirt") and shame at a pupil's excessive praise. 
The dream allows the dreamer to find secret gratification in that praise and antipathy towards the pathological object of his professional activities.

The relationship between the therapist and his patient and that of the master with his pupil are both fraught and sensitive. Later in life, Freud would look back with a sort of nostalgia at these last years of the nineteenth century as his period of "splendid isolation," before the responsibilities of followers or the politics of organization took over. In fact, the student in the 1898 dream associations might stand in for his very first pupil, Felix Gattel (see Hermanns and Schröter 1990, 6). Gattel was a disappointment, and in late 1897, after only six months of Gattel's tutelage and around eight months before this dream, Freud admitted, "I feel toward him as I would toward a wayward son. I wish him the best and must accept his disgrace as mine." In due course, the shared disgrace would become public. The following year, Gattel published "On the Sexual Origins of Neurasthenia and Anxiety Neurosis," and around the time of the dream (June 1898), a certain P. Karplus, an assistant of Krafft-Ebing, published a review of it, which, in effect, lambasted Freud for his pupil's faults. To have followers is to be doubly exposed and vulnerable.

In the early days of the museum's tutelage, its relationship to organized psychoanalysis was ill defined. Though the common perception was that its exhibitions and public program were subject to the dictates of the Freudian analysts on the board, there were, in fact, few on the London committee, and the American joint committee was far away. Richard Wells felt himself under no obligation to confer with them more than was necessary. Standard business practice has it that the basic function of a board should be to either support or fire the CEO. In line with that last clause, and a year or so after Withers's exhibition, Richard Wells was fired.

In the two-step that ideology dances with finance, which of them calls the tune? While Withers had been working on her exhibition, the museum was engaged in its most ambitious and costly project to date: an international conference entitled Speculations, which was held in late 1990. In its wake, the museum's finances were found to be registering a massive six-figure deficit. After Wells's consequent termination, the museum was put on a short leash; the New-Land Foundation now took over doling out its vital annual financial contribution in monthly installments.

2 Sigmund Freud to Wilhelm Fliess, October 31, 1897, in Masson 1985. 
It most probably had nothing to do with Withers. Despite Dr. Couch's misgivings, most reactions to her work had been positive, and from that time onwards, under the directorship of Wells's successor Erica Davies, art exhibitions would become a regular feature of the museum's program. Over the next decade Davies organized regular group and individual exhibitions. In 2002, conceptual artist Stuart Brisley installed an exhibition in the museum. It was called The Collection of Ordure and its concept was an inquiry into the logic of selection, collection, and display. It included an installation in Freud's study featuring (besides glass cases full of unclassifiable detritus) chairs smeared and daubed with extremely verisimilar faeces. This time there was no gilding.

Transmuting visceral disgust into intellectual delight (or, at least, appreciation) requires a greater degree of detachment, or a wider art-historical perspective, than most visitors could perhaps muster. It had been more than ten years since the financial crisis that caused Richard Wells's dismissal. Since that time, the London Management Committee and the Joint Committee in New York had shown their support for the director primarily by insistently urging her to raise funds. But the deficit remained chronic, fund-raising appeals failed to realize the goal of financial independence, and in the summer of 2003, Davies too was fired.

Committees make such decisions in closed sessions, and their discussions are not generally recorded. The part that the art exhibitions played in that decision remains a matter of speculation. My impression was that there were purists on the committee who felt that art was not part of the museum's mission, or that the exhibitions were too frequent, or that they were insufficiently integrated into a psychoanalytic context. Other committee members were, I guess, more pragmatic, and mainly concerned that these exhibitions were failing either to increase overall visitor numbers or to attract significant funding. My guess is that if finances had been in order or if any of the various fundraising drives had been more successful, or if, say, Brisley's Ordure had, like Piero Manzoni's Merda d'artista, sold well (and, of course, on the museum's behalf) at Sotheby's, then Davies might have been vindicated and kept her job. ${ }^{3}$

In any case, trustees might still have voiced ideological objections to art exhibitions in order to reinforce their financial case against the director. And

3 In the 1960s, Manzoni produced a number of sealed tins entitled Merda d'artista. In the year 2000, one of these tins was sold at Sotheby’s for $£ 22,350$. By 2007, the price had risen to $£ 81,000$. 
if they did, I would conjecture a range of arguments, from those of the hardliners, who saw no place at all for art in the museum, to those of the moderates, who conceded that some artists could be trusted to respect psychoanalytic theory, while others could not.

Irresistibly the oneiric image of Freud urinating on the couch comes to mind. In the open-air closet dream, the solid, disgusting matter draws attention away from the action itself, which is urination. This is a lighter, more mercurial theme. In the 1914 and later editions of The Interpretation of Dreams, another significant urinary dream known as "The French nurse's dream," was added to the book. It gained prominence not only for being the only artwork in it, but also because it was not an actual dream but an artist's invention. Eight comic strip illustrations show a sleeping nurse ignoring a child's insistent cries, while a series of images attempts to persuade her that she is already attending to the child's need to urinate. In the images, the child's initial trickle swells into a canal, then into a river, then into an ocean, at which point the necessity of waking finally overcomes the nurse's desire to continue sleeping (Freud [1914] 1953, 368).

The drawings came from the Hungarian comic paper Fidibusz. When Ferenczi sent them to Freud in 1911, Freud wrote back that the artist understood the theory of dreams better than Bleuler, Morton Prince, or Havelock Ellis. ${ }^{4}$ (This eminent trio resisted a wholehearted acceptance of psychoanalysis.) The comment and the inclusion of the images into the book register Freud's endorsement of the artist's role in representing psychoanalytic theory.

Those illustrations are clearly a long way from conceptual art or installations. Though the cartoons may demolish the hardliners' case against artists, the moderates can obviously continue arguing on the grounds that there is art and "art," the latter of which merits exclusion from the museum. This distinction begs the vexed question of how one defines art.

In late 1898, some months after his closet dream, and as if in compensation for Karplus's attack, Freud received an essay by Havelock Ellis that was not only appreciative of his work, but even cited the work of his pupil Gattel (Ellis 1898, 260-99). As Ellis had been among the first foreigners to recognize his work, Freud was, for a long time, predisposed in his favor. Over the years, a certain irritation at Ellis's misunderstanding or resistance to his theory would sour his goodwill, as indicated by the comment to Ferenczi in 1911.

${ }^{4}$ Sigmund Freud to Sándor Ferenczi, May 5, 1911, in Freud and Ferenczi 1993. 
After World War I, Freud saw a paper Ellis had published: "Psychoanalysis in Relation to Sex" (Ellis 1917). Ellis asserted that Freud was an artist, not a scientist. Freud termed this, "the most interesting example of highly sublimated resistance." ${ }^{5}$

Though Freud considered it resistance to call psychoanalysis an art, not a science, this does not mean that his definition of science excludes artistry. He complained to Fliess that he failed to achieve the style he was striving for in The Interpretation of Dreams, ${ }^{6}$ and the technique of dream reading itself is termed an interpretative art: Deutungskunst. What underlies his objection to Ellis's critique is not that Ellis sees art in his work, but that he sees Freud as an artist. The conflict is not between science and art as fields of activity, but between the character of the scientist and the character of the artist.

Perhaps Ellis's remark rankled because it was already too familiarmaybe it even dimly recalled Krafft-Ebing's comment that Freud's aetiology of hysteria was "a scientific fairy tale." Artists gild their dreams to make them socially acceptable, but the gilding is the give-away. Freud's warning that his open-air closet dream "will fill every reader with disgust" carries the implicit message: "this is not art."

Though psychologist and artist alike observe human behavior, their respective communities have different modes of demonstration and validation. While Brisley questioned classification systems and the construction of order through his "collection of ordure," nothing was proved. But was Brisley so different from Ellis, with his respective collection of deviant data, classified without any evident overall system? In the 1930s, discussing the sexologist with the poet H. D., Freud would finally get to turn the tables on Ellis for that aspersion of being an artist: "He [Ellis] records so many funny things that people do but never seems to want to know why they do them" (H.D. 1985, 148).

Case histories may read like novellas and yet be scientific if their core and context are "why." As for the funny things people did or said about art in the museum, it seems to me that many of them might be attributed to this (ultimately sterile) art/science debate. The corroboration offered here-decisions emerging from closeted discussions or a dubious comment-only becomes evidence if placed in the context of years of impressions and experi-

5 "Das interessanteste Beispiel von hoch sublimiertem Widerstand." See Sigmund Freud to Max Eitingon, February 15, 1920, in Schröter 2004.

6 See Sigmund Freud to Wilhelm Fliess, September 11, 1899, and September 21, 1899, in Masson 1985. 
ences building up to a climate of opinion, the bad weather prevailing around the museum at the time.

Attitudes have since changed. Control of the Museum has since passed from Archives Inc. and the Joint Committee to the London Committee alone, and the art exhibitions continue. The latest one includes the installation "Gavin Turk's Desk," cluttered with objects in imitation of Freud's. Object 49 is a cracked tin can entitled "Ordure": the artist's label states that it is "a musing on Piero Manzoni's Merda d'artista" and that it is "imagined that the artist's shit had escaped."

Dr. Couch, being dead, is not available for comment. As always in art history, scandals are assimilated into tradition and orthodoxy. Reality continues to evade capture.

In Freud's open-air closet dream, the stream of urine supposedly "washed everything clean." Yet the final sentence of the dream account adds: "It was as though at the end there was still some left." This apparent afterthought is left uninterpreted. How could this residue be read?

I make no exclusive claims for the following conjectures.

The problem about case histories sounding like novellas is, as Freud stated, that they thereby "lack the serious stamp of science." (This is the Standard Edition translation: the original word, Wissenschaftlichkeit, denotes scientificity or a scientific approach, rather than science in the abstract.) His indignation at the comments made by Krafft-Ebing or Havelock Ellis was aroused by their aspersions against a style or approach that does not accord with their notions of science. It is a sore point, because, unlike his friend Fliess, Freud did not have recourse to mathematics. His own innate sense of style was outraged by the devious phraseology and forced circumlocutions he found himself using. It is probable that something like this dissatisfaction, in this instance deriving from the lecture he has just given, infects the dream and its associations.

Alternatively (or additionally), the dissatisfaction expressed in the dream associations relates to the practice of therapy. In either instance, the residue remains as an enduring trace of the analyst's own self-disgust. This is dirt that cannot be washed away. And perhaps it should not, because it represents the analyst's self-critical faculty, so necessary for the successful practice of the profession and the antidote to the delusions of grandeur that pervade the dream. The delight was transitory: the residue of disgust remains as a link to reality. It is the sting in the tail, a reminder that, awake, the dreamer will no longer be a mythic giant. 
Taking the interpretation one step further, it acquires a philosophical twist. Excrement is a problem for conceptual as well as physical hygiene. It is produced as a consequence of appetite and pleasure. It is inside us and then it is expelled; it involves attraction and repulsion, inside and outside worlds. In short, it confuses categories.

Ambivalence and ambiguity are discomforting. There is something like an atavistic proto-scientific longing for conceptual purity and well-defined ideas. In this realm of moral philosophy, Freud's dream might be presented as a warning to himself against such temptations. The delight of having washed away the impurity of human dirt was premature. The scientist is human after all, still hopelessly involved in the stuff of observed reality. No need for further comment, the evidence is there in the punchline: "there was still some left."

\section{REFERENCES}

Ellis, Havelock. 1898. "Auto-Erotism: A Psychological Study." The Alienist and Neurologist 19: 260-99.

_. 1917. "Psychoanalysis in Relation to Sex." Journal of Mental Science 63 (October): $537-55$.

Freud, Sigmund. 1953. The Standard Edition of the Complete Psychological Works of Sigmund Freud. Vol. 5. Edited by James Strachey. London: Hogarth.

Freud, Sigmund, and Sándor Ferenczi. 1993. The Correspondence of Sigmund Freud and Sándor Ferenczi. Vol. 1, 1908-1914, edited by Eva Brabant, Ernst Falzeder, and Patrizia Giampieri-Deutsch. Cambridge, MA: Harvard University Press.

H. D. 1985. Tribute to Freud. Manchester: Carcanet.

Hermanns, Ludger M., and Michael Schröter. 1990. "Felix Gattel (1870-1904): Der erste Freudschüler." Luzifer-Amor 6: 42-75.

Masson, Jeffrey M., ed. 1985. The Complete Letters of Sigmund Freud to Wilhelm Fliess 1887-1904. Translated by Jeffrey M. Masson. Cambridge, MA and London: The Belknap Press of Harvard University Press.

Schröter, Michael, ed. 2004. Briefwechsel 1906-1939. Sigmund Freud und Max Eitingon. Tübingen: edition diskord. 



\title{
Anomalies of Demarcation in Light of the Nineteenth-Century Occult Revival
}

\author{
Júlia Gyimesi
}

Recently, special attention has been paid to the problems of boundary work in the nineteenth- and twentieth-century history of psychology (Lachapelle 2011; Plas 2000; Sommer 2012; Wolffram 2009). As it has been revealed, the differentiation between science and pseudoscience was a particularly urgent need in academic psychology (Keeley 2001; Gyimesi 2016a). Actually, from a certain point of view, differentiation, exclusion, and inclusion were some of the basic tasks of early experimental psychologists, psychoanalysts, psychotherapists, etc. They were pioneers of their time, and they not only sought to develop new concepts, accumulate evidence, and designate new fields of research in their work, but also sought to distance themselves from other fields of research or popular practices. It is not surprising that even Sigmund Freud himself introduced his essay on the history of the psychoanalytic movement with the following words:

If in what follows I bring any contribution to the history of the psychoanalytic movement nobody must be surprised at the subjective nature of this paper, nor at the role, which falls to me therein. For psychoanalysis is my creation; for ten years I was the only one occupied with it, and all the annoyance which this new subject caused among my contemporaries has been hurled upon my head in the form of criticism. Even today, when I am no longer the only psychoanalyst, I feel myself justified in assuming that none can know better than myself what psy- 
choanalysis is, wherein it differs from other methods of investigating the psychic life, what its name should cover, or what might better be designated as something else. (Freud 1914, 7)

The differentiation between psychoanalysis and other fields of psychology had always been a sensitive question for Freud. His break with Jung was primarily due the efforts of Jung to broaden the scope of psychoanalysis and desexualize the Freudian concept of libido (Gyimesi 2009). According to Freud, Jung aimed at introducing the "black tide of mud" (Jung 1961, 173), namely occultism, into the psychoanalytic edifice, and in so doing, he would have definitively altered the foundations of psychoanalysis. Freud was not alone in his fear of the so-called occult. Modern occult practices were rather widespread in nineteenth and early twentieth-century Western culture. Several of their suppositions-such as the non-materialistic, disembodied nature of the human psyche-proved acceptable for laymen and psychological thinkers alike. In the eyes of the representatives of materialistic, mechanistic science, the growing number of "occultists" seemed threatening (Monroe 2008; Oppenheim 1988; Owen 2004; Treitel 2004).

It is not surprising that, in the past decades, the cultural and scientific significance of modern occult practices such as spiritism, spiritualism, and related movements, became an important field of research for several historians of psychology (e.g., Ellenberger 1970; Owen 2004; Treitel 2004; Plas 2000; Rabeyron and Evrard 2012). As it has been revealed, modern spiritualism influenced the evolution of psychology significantly, despite the concerns of Freud and others. The systematic observation of spiritualist mediums, the experiments on spiritualistic phenomena proved to be a promising field of research for numerous early psychologists. Their results called attention to the as yet unknown characteristics of the human psyche, even though most of the psychologically oriented researchers in this field were fairly skeptical regarding the genuineness of spiritualistic phenomena (Gyimesi 2012, 2014, 2016a; Rabeyron and Evrard 2012; Sommer 2012; Wollfram 2009).

It is remarkable that besides William James $(1886,1890$ a, 1902), Théodore Flournoy (1896, 1900, 1911), Carl Gustav Jung (1896, 1897, 1902, 1948, 2009) and many others, Freud himself was also interested in the so-called occult, although in a rather ambivalent way. Actually, he was so interested in the possibility of thought-transference that he tried to understand it by supposing as yet unknown physical forces in the background (Devereux 1953; Freud 1914, 1921, 1922, 1933). However, he was very much aware of the risks 
of openly supporting the experiments on thought-transference. Therefore, he did not publish his ideas on thought-transference until 1921, and he also tried to prevent his disciples, such as Sándor Ferenczi, from publishing their results on the subject:

I see destiny approaching inexorably, and I note that it has designated you to bring to light mysticism and the like, and that it would be just as futile as it is hard-hearted to keep you from it. Still, I think we ought to venture to slow it down. I would like to request that you continue to research in secrecy for two full years and don't come out until 1913; then, certainly, in the Jahrbuch, openly and aboveboard. You know my practical reasons against it and my secret painful sensitivities. ${ }^{1}$

Ferenczi was obedient to his master and did not publish his results. ${ }^{2}$ However, he was deeply involved in spiritualism throughout his entire life. He was obviously not a spiritualist, but he recognized the rich field of research offered by spiritualistic practices and compelled systematic investigation of spiritualistic and related occurrences. His main interest, similar to Freud, remained thought-transference. However, in his view, it gained a rather comprehensive psychoanalytical significance (see Ferenczi 1919a; 1919b; 1928; 1932; Gyimesi 2016a).

The case of Ferenczi tells us a great deal about the difficulties regarding the designation of the borders of psychology in general and psychoanalysis in particular. The aim of this chapter is to show that the process of demarcation in psychology and psychoanalysis was influenced by multiple meta-theories that may have originated in the basic trends of contemporary science, but also in personal ambitions, fears, and anxieties. Furthermore, personal preferences were never independent from the broader psychosocial context, not even from political trends. Thus, my aim is to illuminate the complex origins of the process of demarcation in psychology by using the following examples from the history of the intersection of psychology and spiritualism.

${ }^{1}$ Letter from Sigmund Freud to Sándor Ferenczi, December 3, 1910, in Freud and Ferenczi 1993, 239-40.

2 In fact, he has never published his results. 


\section{Spiritualism on the Threshold of Psychology}

It is well known today that spiritualism had widespread cultural influence in the late nineteenth and early twentieth centuries (Plas 2000; Lachapelle 2002; Luckhurst 2002). It emerged in connection with the growing power of scientific materialism signifying a revolt against the materialistic, naturalistic interpretation of existence. But it was also a consequence of the crisis of traditional western religions in that spiritualists were disappointed in western religions, but they did not give up their need for religious experience (Thurschwell 2001; Owen 2004; Treitel 2004). Thus, spiritualism reflected the basic need for spirituality in the age of disenchantment (Doyle 1926; Podmore 1902).

It is less known that several spiritualists forced systematic investigations into the field of spiritualistic phenomena. Their primary aim was to convince skeptics of the genuineness of spiritualistic occurrences. For this purpose, a great number of spiritualists were ready to introduce very strict scientific methods into the séance room. Furthermore, numerous spiritualists identified themselves as distinct researchers practicing a new discipline on the border of faith and science. As a result, the scientific efforts of spiritualists generated growing attention in and beyond academic circles. Spiritualists developed new techniques of exploration, while skeptics extended the well-known methods of natural science to spiritualistic occurrences. Due to these efforts, new branches of science were born, first of all psychical research, ${ }^{3}$ which significantly influenced the development of modern psychology (e.g., Flournoy 1896; Myers 1903; Podmore 1902; Richet 1923).

Those investigators of spiritualism who were skeptical regarding the spiritualistic interpretation of spirit intervention but accepted the genuineness of some spiritualistic occurrences tried to understand spiritualistic phenomena as a result of an as yet unknown function of the human psyche. They put questions of telepathy or premonitions into a rational, scientifically based framework in which these debatable phenomena gained psychological significance. Hereby psychological theories were born which reflected on mainstream psychological questions such as the subconscious layers of the personality, automatisms, dissociation, and altered states of consciousness. The

3 The Society for Psychical Research was founded in London in 1882. The representatives of the Society encouraged systematic and objective investigation into the fields of hypnotism, mesmerism, spiritualistic, and related phenomena. 
important theories of Frederic Myers (1903), Théodore Flournoy (1896, 1900, 1911), and Charles Richet $(1905,1923)$ were all created in the fertile context of spiritualism. Furthermore, spiritualism offered a new ideology with strong psychological content. As a new discipline that focused on spiritual, ethical, and developmental tasks, it also proved stimulating for several early psychologists such as Carl Gustav Jung $(1896,1897,1902)$ and Sándor Ferenczi (1899).

Similar to other countries in Europe, by 1853 spiritualism spread to Hungary. The first Hungarian authors dealing with spiritualism were Count Ferenc Szapáry (e.g., 1854a, 1854b) and Baron Lázár Hellenbach (e.g., 1878). The latter played a leading role in the history of Hungarian spiritualism, since he conducted mediumistic experiments with Baroness Adelma Vay, who later became the founder of Hungarian institutionalized spiritualism. Several members of the noble Vay family practiced spiritualism, but among them only the Baroness and her husband Baron Ödön Vay influenced Hungarian spiritualism significantly (Tordai 2008).

It was a physician, János Gárdos, who introduced Baroness Vay to the field of spiritualism. At the time, Gárdos was a well-known expert who used animal magnetism in his therapeutic practice. In 1865, he met the Baroness, who was suffering from severe migraines and seizures. According to Gárdos's diagnosis, Baroness Vay was a seer for whom the only effective cure was "magnetic writing." After some resistance against the diagnosis, the Baroness accepted the cure and began practicing as a writing medium (Grünhut 1932). She published a number of books; her most important work was Spirit, Power, Matter (1869), which she wrote at the age of twenty-six through automatic writing.

Several spiritualist circles were born in Hungary for the purpose of investigating mediumistic and related phenomena. Among these were the Budapest Association of Spiritual Investigators (Szellemi Búvárok Pesti Egylete), founded by the physician Adolf Grünhut and the medium Baroness Adelma Vay in 187. It became a prominent forum of Hungarian spiritualism and spiritism, ${ }^{4}$ publishing books and journals (see Égi Világosság [Heavenly Light]). Grünhut, who previously also practiced animal magnetism, met Adelma Vay in 1870 . He was deeply impressed by the somnambulistic, me-

${ }^{4}$ In Hungary, the system of Allen Kardec became very popular in the late nineteenth century. Therefore his term "spiritism" was used in mediumistic practices. Later spiritists deviated from the ideas of Kardec. However the term "spiritism" survived and referred to spiritualism in general in Hungary. 
diumistic capacities of the woman, and their cooperation proved to be extremely fruitful (Gürnhut 1932).

It must be added that the systematic and objective research of mediumistic and connected phenomena was rather rare among the representatives of the Budapest Association of Spiritual Investigators, since religious commitments in their circle were very strong. Their main theoretical basis was the system of Allen Kardec, which they expanded with their own views. Christian content was fundamental to their ideology; their primary aim was to work in a unified Christian faith and spread the so-called "evangelistic spiritism" all over the world (Pataki 2003; Tarjányi 2002; Tordai 2008). Unfortunately, in the 1940s anti-Semitism, nationalism, and Christianity were strongly interconnected in spiritualist groups, which had far-reaching consequences for the development of scientifically oriented spiritualism and early parapsychology in Hungary. The accentuation of the religious, namely Christian elements of evangelistic spiritism became a tool used to exclude Jews and "alien" ideologies; but this became a serious obstacle to objective, well-controlled experimentation of spiritualistic phenomena. The strong religious content of evangelistic spiritism foreclosed the possibility of questioning, measuring, or doubting. Therefore, the tradition of evangelistic spiritism not only narrowed the scope of research on the paranormal, but easily served the political tendencies of the 1940s (Gyimesi 2016).

\section{Inclusion and Exclusion-Spiritualism and Contemporary Science in Hungary}

As elsewhere in Europe, spiritualism had a diverse and complex influence on contemporary science in Hungary (Gyimesi 2014, 2016a, 2016b). Spiritualistic and related phenomena, such as somnambulism or animal magnetism proved to be a stimulating field of research already in the late nineteenth century. The trance states of the magnetized mediums called attention to the psychological questions of suggestion and hypnosis. Therefore, the investigation of animal magnetism gained central significance for the early theoreticians of hypnosis as well. It was Pál Ranschburg and Károly Décsi who first published a book on the critical experimental analysis of animal magnetism (1900). According to their conclusion, magnets have no influence on human organisms. The mysterious recoveries of patients are due to the effects of hypnosis and suggestion. 
Pál Ranschburg, the founding father of Hungarian experimental psychology, had extraordinary influence on the development of Hungarian academic psychology. It is worth noting that his book, entitled Psychotherapies: On Magnetism, Its Influence on the Human Organism and Its Possible Inner and Outer Therapeutic Effects, which he co-authored with Décsi, was the first recipient of the Gárdos Award. The cures of the well-known magnetizer, János Gárdos, were considered to be extremely successful in the nineteenth century. When Gárdos's widow, Júlia Andrássy, died in 1894, she bequeathed a large amount of money to the Medical Professorial Syndicate for the purpose of creating an award named after her husband. According to the widow's will, the aim of the award was to support research on the influence and therapeutic effects of magnetism using the notes and the library of her deceased husband. Although Ranschburg's and Décsi's conclusion was, in fact, a comprehensive criticism and denial of the work of Gárdos and magnetism, the Medical Professorial Syndicate still decided to give them the award (Gyimesi 2014). It is rather obvious that the aim of Ranschburg was to demarcate the theory of hypnosis from the mysterious, seemingly occultish content of animal magnetism and somnambulism. In achieving this objective, he opened the way for the rationalistic, scientific interpretation of hypnosis, which proved to be essential in the further development of hypnotherapies in Hungary. The decision of the Medical Professorial Syndicate supported Ranschburg, and likewise the demarcation of the theory of hypnosis from animal magnetism.

While Ranschburg and his colleagues clearly rejected the spiritualistic, "occult" content of animal magnetism, there were others who were less rigorous in evaluating the debatable theories that originated in animal magnetism and spiritualism. As it was mentioned before, Sándor Ferenczi, for instance, forced systematic research in the field of spiritualistic phenomena:

Therefore the antagonists of spiritism should not use denial before or without investigation in their crusade. They should devote themselves to the investigation of the claimed facts with the same objectivity that characterizes science in other fields. They should not shrink from sitting down at the moving table or from visiting spiritist gatherings of lay people. After all, from the sociological point of view alone, the subject is important enough to attract the attention of the best minds. Let them take with themselves the arsenal of science, let them organize experimental séances, observe, rule out intentional deception and decide how much is delusion and how much is truth. (Ferenczi 1899, 143) 
In fact, Ferenczi searched for the "truth" in spiritualistic phenomena all of his life. His aim was not to prove the existence of afterlife or spirit intervention, but to discover the psychological rules that manifest themselves in the séance room. After the publication of his famous paper "On Spiritism" in 1899, Ferenczi wrote a review on the book of the spiritualist and psychical researcher Lajos Wajdits (Essays on the Field of Spiritualism) in 1900, in which he criticized Wajdits's efforts to bring spiritualism and science closer. He advocated for psychological experiments in the Budapest Association of Spiritual Investigators and welcomed Wajdits's initiative to use scientific exploration in the practice of spiritualism (Ferenczi 1900a).

In the same year, Ferenczi published a further review on the book of Leopold Löwenfeld entitled "Somnambulismus und Spiritismus" (1900b). Similar to his earlier review, Ferenczi pointed at the lack of true scientific investigations in the field of spiritualistic phenomena and somnambulism. Ferenczi also translated Sante de Sanctis's essay entitled "Miraculous Element in Dreaming," in which the author discussed the current position of psychical researchers. In one of his footnotes, Ferenczi expressed his agreement concerning the importance of scientific exploration in the realm of the so-called supernatural (De Sanctis 1902, 358) and he seemed to be very rigorous in this question (De Sanctis, 1902, 365). It is rather easy to already see the openminded, innovative thinking that led him to the border zones of medicine in his early years. In fact, Ferenczi was a psychical researcher in a society that ignored the true scientific exploration of the "supernormal" (Rickman 1933).

Although several leading figures of Hungarian spiritualism were very close to science, critical attitudes were rarely present in their investigations. The physician Adolf Grünhut became a genuine spiritualist after 1871. The former disciple of the occultist Carl du Prel, János Mikos's efforts to found a scientific school of spiritualism in Hungary failed (Mikos 1897). Physicians generally remained aloof from the question of spiritualism (e.g., Szörényi 1894). However, Ferenczi insisted on the psychological significance of spiritualistic phenomena. Although he did not publish his observations, he developed many different theories on the functioning of thought-transference (see Ferenczi 1932; Gyimesi 2011, 2012, 2016a). According to him, thought-transference was based on the interconnectedness of different psyches, or more precisely, on the interconnectedness of different unconsciousness. In this way, in Ferenczi's view, it was possible to communicate on an unconscious, primitive, and nonverbal level. He also connected the phenomena of telepathy to increased sensitivity, which he found to be fundamental in certain psychopa- 
thologies such as paranoia or hysteria. He observed this increased sensitivity in children and in suffering patients, too, who somehow - normally based on a traumatic experience-developed telepathic capacities (Ferenczi 1932).

It must be added that Ferenczi's famous patient and disciple, Elizabeth Severn (referred to as "R. N." in his diary), could have played a determining role in the development of Ferenczi's theories on telepathy. Severn was a patient of his in the last eight years of his life, and during this period, a strong professional and personal relationship evolved between them. Today, it is very likely that Severn influenced Ferenczi not only emotionally but theoretically also (Fortune 1993, 1996; Rachman 2015; Rudnytsky 2015). Severn combined psychoanalytical knowledge with spiritual ideas and experiences (e.g., Severn 1933); during his relationship with Severn, Ferenczi reactivated his early ideas on telepathy. As a result, contradictory but far-reaching theories were born:

Cases of thought transference during the analysis of suffering people are extraordinarily frequent. One sometimes has the impression that the reality of such processes encounters strong emotional resistance in us materialists; any insights we gain into them have the tendency to come undone, like Penelope's weaving or the tissue of our dreams.

It is possible that here we are facing a fourth "narcissistic wound," namely that even the intelligence of which we are so proud, though analysts, is not our property but must be replaced or regenerated through the rhythmic outpouring of the ego into the universe, which alone is all knowing and therefore intelligent. But more of this another time. (Ferenczi 1932, 33)

While Ferenczi was ready to use his observations on telepathy in his theoretical argument, he was conscious of the differentiation between the materialistic and the spiritualistic point of views (see Ferenczi 1932; Gyimesi 2011, $2012,2016 a)$. In this sense, he was aware of the dangers generated by the disguised, pseudoscientific dimensions of psychology. Spiritualism could not threaten the objectivity of psychology until spiritualistic, occult contents were clearly differentiated from scientific psychological theories.

Of course, there were many others who were much less cautious in demarcating science and pseudoscience. A good example of this is the oeuvre of Ferenc Völgyesi, who developed remarkable theories on the functioning of hypnosis in the twentieth century. He achieved fame primarily due to his experiments on animal hypnosis, which proved to be a popular complementary 
field of hypnosis research. As Völgyesi summarized, his ideas originated in the neurophysiologic results of Ivan Pavlov; he identified the roots of hypnosis in neurological mechanisms. He published several works on animal and human hypnosis, providing a comprehensive theory on the possible mechanisms of hypnosis (e.g., Völgyesi 1930, 1932, 1933, 1936, 1962).

According to the accounts of Völgyesi, starting when he was a medical student and later on, after he founded his medical practice, he focused on the problems of hypnosis and psychological suggestion. However, in the beginning of his career, Völgyesi was deeply involved in the investigation of the performances of spiritualist mediums. As he asserted later, his primary aim was to understand the functioning of suggestion and hypnosis in the framework of the natural sciences. Therefore, he started to conduct experiments with stage hypnotists, clairvoyants, and spiritualist mediums. He also investigated the well-known Hungarian medium László László. As it has been revealed, László László was a fraud medium and allegedly a criminal. The debunking of the medium (which was not the result of Völgyesi's experiments) damaged the fame of Hungarian parapsychology significantly, but this also diverted Völgyesi from the experimental study of mediums. Before the László László incident, Völgyesi played an important role in several scientifically oriented branches of spiritualism in Hungary. In these circles Völgyesi was presented as an expert on the border of science and spiritualism (Tordai 1923a, 1923b; Rátai 2000). However, after he exposed László László, Völgyesi gave up on the support of early parapsychological research. It was the Pavlovian theory that separated him from spiritualism, thus creating a boundary between scientific psychology and "occultism" (Völgyesi 1940).

In fact, the materialistic (Pavlovian) and experimental foundations of the ideas of Völgyesi on animal hypnosis were deeply questionable and unelaborated. However, Pavlovian theory offered an up-to-date and biologically based background for his theoretical innovations. By using the psycho-physiological framework of Pavlov, which was extremely popular and had enormous influence on Hungarian academic psychology, Völgyesi legitimated his truly pseudoscientific suppositions on animal hypnosis.

\section{Conclusions}

It is well-known today that the evolution of science is never independent from cultural, political, or financial interests. Furthermore, it is also obvious that personal histories, ambitions, or anxieties can significantly influence the de- 
velopment of professional attitudes. In this sense, objectivity is often questionable. However, it is crucial to be aware of the true nature of pseudoscientific reasoning.

Spiritualism and related movements obviously influenced the professional development of Freud, Ferenczi, Ranschburg, and Völgyesi. However, their attitudes regarding spiritualism were rather diverse. Although Ferenczi was strongly committed to the research of spiritualistic phenomena, he made a clear distinction between spiritualistic and materialistic approaches. Others, such as Freud and Ranschburg, primarily focused on the separation of "occultism" and "science." Although their aims were well established, the radical split forced by them could have led to dangerous uncertainties in their fields. Maybe it is not accidental that besides Ferenczi, Freud's other disciples such as Jung and Stekel (1913) were also involved in research on the so-called supernatural. Maybe it is not accidental that after Ranschburg's demarcation of animal magnetism from hypnosis, Völgyesi's unscientific theory could emerge and flourish for decades. It is very likely that unelaborated demarcation processes could have left several uncertainties behind that later came back in disguised forms. As a result, true pseudoscientific reasoning, which preserved the once detached, non-scientific content using mainstream theoretical frameworks, could emerge. In this sense, spiritualism has never posed a threat to scientific psychology. The real threat lies in unelaborated demarcation processes that preserve non-scientific content in latent and hidden conceptual frameworks and theories. What is more, these contents are probably still living with us in several fields of contemporary psychology.

\section{REFERENCES}

De Sanctis, Sante. 1902. "A csodás elem az álomlátásokban" [The miraculous element in dreaming]. In Ferenczi Sándor: A pszichoanalízis felé [Towards psychoanalysis], edited by Judit Mészáros, 357-65. Budapest: Osiris.

Décsi, Károly, and Pál Ranschburg. 1900. Lelki gyógymódok (Psychoterapia). A magnetizmusról, annak az emberi szervezetre való hatásáról és lehetö külső és belső gyógyalkalmazásáról [Psychotherapies: On magnetism, its influence on the human organism, and its possible inner and outer therapeutic effects]. Budapest: Franklin.

Devereux, Georges. 1953. Psychoanalysis and the Occult. London: International University Press.

Doyle, Arthur Conan. 1926. The History of Spiritualism. London, New York, Toronto, and Melbourne: Cassel and Company. 
Ellenberger, Henri Frédéric. 1970. The Discovery of the Unconscious: The History and the Evolution of Dynamic Psychiatry. London: The Penguin Press.

Ferenczi, Sándor. (1899) 1963. “Spiritism.” Psychoanalytic Review 50A: 139-44.

— 1900a. "Somnambulismus und Spiritismus (Leopold Löwenfeld könyvének ismertetése)" [Somnambulism and spiritism: A review of the book by Leopold Löwenfeld]. Gyógyászat 40, no. 46: 730.

— 1900b. “Tanulmányok a szellemtan köréből (spiritizmus) (Wajdits Lajos könyvének ismertetése)" [Essays on the field of spiritualism (a review of the book of Lajos Wajdits)]. Gyógyászat 40, no. 27: 426.

_ . (1919a) 1926. “The Phenomena of Hysterical Materialization.” In Further Contributions to the Theory and Technique of Psycho-Analysis, edited by John Rickman, 89-104. London: Karnac Books.

_ . (1919b) 1926. "An Attempted Explanation of Some Hysterical Stigmata." In Further Contributions to the Theory and Technique of Psycho-Analysis, edited by John Rickman, 110-18. London: Karnac Books.

- (1928) 2002. “The Elasticity of Psychoanalytic Technique." In Final Contributions to the Problems and Method of Psycho-Analysis, edited by Michael Balint, 87-102. London: Karnac Books.

— . (1932) 1995. The Clinical Diary of Sándor Ferenczi. Cambridge, MA: Harvard University Press.

Freud, Sigmund, and Sándor Ferenczi. 1993. The Correspondence of Sigmund Freud and Sándor Ferenczi. Vol. 1, 1908-1914, edited by Eva Brabant, Ernst Falzeder, and Patrizia Giampieri-Deutsch. Cambridge, MA: Harvard University Press.

Flournoy, Théodore. 1896. Notice sur le laboratoire de Psychologie de l'Université de Genève. Genève: Librairie Ch. Eggimann \& Cie.

- 1900. Des Indes à la Planète Mars. Étude sur un cas de somnambulisme avec glossolalie. Paris/Genève: F. Alcan/Ch. Eggimann.

— 1911. Spiritism and Psychology. New York: Harper \& Brothers.

Fortune, Christopher. 1993. “The Case of 'RN': Sándor Ferenczi's Radical Experiment in Psychoanalysis." In The Legacy of Sándor Ferenczi, edited by Lewis Aron and Adrienne Harris, 100-21. London: The Analytic Press.

_. 1996. "Mutual Analysis: A Logical Outcome of Sándor Ferenczi’s Experiments in Psychoanalysis." In Ferenczi's Turn in Psychoanalysis, edited by Peter Rudnytsky, Antal Bókay, and Patrizia Giampieri-Deutsch, 170-89. New York and London: New York University Press.

Freud, Sigmund. 1899. “A Premonitory Dream Fulfilled.” SE 5: 623-25.

— 1914. "On the History of the Psycho-Analytic Movement." SE 14: 7-65.

_ . 1921. "Psychoanalysis and Telepathy." SE 18: 175-93.

_ 1922. "Dreams and Telepathy." SE 18: 197-220.

_. 1933. "Dreams and Occultism." SE 22: 31-56.

Grünhut, Adolf. 1932. Tanulmányok a spiritizmus köréből: magnetizmus, szomnambulizmus, mediumizmus [Essays in the field of spiritualism: Magnetism, somnambulism, mediumism]. Budapest: Szellemi Búvárok Pesti Egylete.

Gyimesi, Júlia. 2009. "The Problem of Demarcation: Psychoanalysis and the Occult.” American Imago 66, no. 4: 457-70. 
2011. Pszichoanalízis és spiritizmus [Psychoanalysis and spiritualism]. Budapest: Typotex.

. 2012. "Sándor Ferenczi and the Problem of Telepathy." History of the Human Sciences 25: 131-48.

_ . 2014. "Between Religion and Science: Spiritualism, Science, and Early Psychology in Hungary." International Psychology, Practice and Research 5: 1-20.

_ 2016a. "Why 'Spiritism'?" The International Journal of Psychoanalysis 97: 357-83.

- 2016b. "The Institutionalization of Psychical Research and Parapsychology in Hungary in the Twentieth Century." In Okkulte Moderne, edited by Anna Lux and Sylvia Paletschek, 201-24. Berlin: De Gruyter.

Hellenbach, Lazar. 1878. Mr. Slade's Aufenthalt in Wien. Wien: Fischer.

James, William. (1890a) 1986. "A Record of Observation of Certain Phenomena of Trance." Essays in Psychical Research, edited by Frederick H. Buckhart, Fredson Bowers, and Ignas K. Skrupskelis, 79-89. Cambridge, MA and London: Harvard University Press.

_ . (1890b) 1986. "Report of the Committe on Mediumistic Phenomena." In Essays in Psychical Research, edited by Frederick H. Buckhart, Fredson Bowers, and Ignas K. Skrupskelis, 14-19. Cambridge, MA and London: Harvard University Press.

- 1902. The Varieties of the Religious Experience. New York: Penguin Books.

Jung, Carl Gustav. (1896) 1983. “The Border Zones of Exact Science.” In The Collected Works of C. G. Jung. Supplementary Volume A, 5-19. London: Routledge and Kegan Paul.

—_ (1897) 1983. "Some Thoughts on Psychology." In The Collected Works of C. G. Jung. Supplementary Volume A, 23-47. London: Routledge and Kegan Paul.

- 1902. "On the Psychology and Pathology of So-Called Occult Phenomena." In Collected Papers on Analytical Psychology, 1-93. New York: Moffat Yard and Company.

— 1948. "Psychologie und Spiritismus." Neue Schweizer Rundschau 16, no. 7: 430-35.

. (1961) 1993. Memories, Dreams, Reflections. Edited by Aniela Jaffé. London: Fontana.

_. 2009. The Red Book: Liber Novus. New York and London: W. W. Norton.

Keeley, James P. 2001. "Subliminal Promptings: Psychoanalytic Theory and the Society for Psychical Research.” American Imago 58, no. 4: 767-91.

Lachapelle, Sophie. 2011. Investigating the Supernatural: From Spiritism and Occultism to Psychical Research and Metapsychics in France, 1853-1931. Baltimore: Johns Hopkins University Press.

Luckhurst, Roger. 2002. The Invention of Telepathy, 1870-1901. Oxford: Oxford University Press.

Mikos, János. 1897. “A szerkesztő előszava” [Foreword by the Editor]. Rejtelmes Világ (August): 3-4.

Monroe, John Warne. 2008. Laboratories of Faith: Mesmerism, Spiritism, and Occultism in Modern France. Ithaca and London: Cornell University Press.

Myers, Frederic William Henry. 1903. Human Personality and Its Survival of Bodily Death. London: Longmans, Green and Co. 
Oppenheim, Janet. 1988. The Other World: Spiritualism and Psychical Research in England, 1850-1914. Cambridge: Cambridge University Press.

Owen, Alex. 2004. The Place of Enchantement: British Occultism and the Culture of the Modern. Chicago and London: University of Chicago Press.

Pataky, Árpád. 2003. Bevezetés a spiritológiába [Introduction to spiritology]. Budapest: Magánkiadás.

Plas, Regine. 2000. Naissance d'une science humaine: la psychologie. Les psychologues et le "merveilleux psychique." Paris: Presses Universitaires de Rennes.

Podmore, Frank. 1902. Modern Spiritualism: A History and a Criticism. London: Methuen and Co.

Rabeyron, Thomas, and R. Evrard. 2012. "Historical and Contemporary Perspectives on Occultism in the Freud-Ferenczi Correspondence." Recherches en psychanalyse 13: 98-111.

Rachman, Arnold. 2015. "Elizabeth Severn: Sándor Ferenczi’s Analysand and Collaborator in the Study and Treatment of Trauma." In The Legacy of Sándor Ferenczi: From Ghost to Ancestor, edited by Adrienne Harris and Steven Kuchuck, 111-126. London and New York: Routledge.

Rátay, János. 2000. Spiritizmus, parapszichológia. A szellem kalandjai életen innen és túl [Spiritism, parapsychology: The adventures of the spirit in and beyond life]. Budapest: Elipszilon.

Richet, Charles. 1905. "La métapsychique." Proceedings of the Society for Psychical Research 19: 2-49.

- 1923. Thirty Years of Psychical Research: Being a Treatise on Metapsychics. London: W. Collins Sons.

Rickman, John. 1933. “Obituary: Sandor Ferenczi.” In Proceedings of the Society for Psychical Research 33: 124-5.

Rudnytsky, Peter. 2015. "The Other Side of the Story: Sebern on Ferenczi and Mutual Analysis." In The Legacy of Sándor Ferenczi: From Ghost to Ancestor, edited by Adrienne Harris and Steven Kuchuck, 134-49. London and New York: Routledge.

Severn, Elizabeth. 1933. The Discovery of the Self: A Study in Psychological Cure. Philadelphia: David McKay Company.

Stekel, Wilhelm. 1913. “Telepathische Träume.” Psychische Studien 40, no. 3: 156-165.

Sommer, Andreas. 2011. "Psychical Research and the Origins of American Psychology: Hugo Münsterberg, William James, and Eusapia Palladino.” History of the Human Sciences 25: 23-44.

Szapáry, Ferenc. 1854a. Table-Moving. Somnabulisch-Magnetische Traumdeutung. Paris: Bonaventure und Ducessois.

—. 1854b. Magnétisme et Magnétothérapie. Paris: Dentu.

Szörényi, Tivadar. 1894. "Spiritismus. Somnambulismus. Kettős öntudat (vigilambulismus)" [Spiritism; Somnambulism; Dual self-consciousness]. Gyógyászat (July 1): 311-314.

Tarjányi, Eszter. 2002. A szellem örvényében: a magyarországi mesmerizmus, szellemidézés, teozófia története és müvészeti kapcsolatai [In the whirlwind of spirit: The history of mesmerism, spiritualism, theosophy and their relationship with art in Hungary]. Budapest: Universitas. 
Tordai, Vilmos. 1923a. Bevezetö a metapszihikába. A kecskeméti és a karcagi dobálások mint metapszihikai jelenségek [Introduction to metapsychics: The phenomena in Kecskemét and Karcag as metapsychical phenomena]. Budapest: Kókai.

- 1923b. Okkult elemek a magyarság életében [Occult elements in the life of the Hungarians]. Budapest: Kultura.

Treitel, Corinna. 2004. A Science for the Soul: Occultism and the Genesis of the German Modern. Baltimore and London: Johns Hopkins University Press.

Vay, Adelma. (1869) 1923. Szellem, erő, anyag [Spirit, power, matter]. Budapest: Szellemi Búvárok Pesti Egylete.

Völgyesi, Ferenc. 1930. Kényszerneurosis és hypnosis-gyógymód [Obsessional neurosis and hypnosis-therapy]. Budapest: Novák.

. 1932. Üzenet az ideges embereknek [Message to the neurotic humanity]. Budapest: Bibliotéka.

. 1933. Mesmer és a "gyógydelejezés" [Mesmer and "animal magnetism"]. Budapest: Novák.

- 1936. Ember-és állat-hypnosis (tekintettel az agy phylo-és ontogenesisére) [Human and animal hypnosis (concerning the phylo- and ontogenesis of the brain)]. Budapest: Novák.

_ 1940. Minden a lélek: orvosok és orvostanhallgatók részére [The soul is everything: For doctors and medical students]. Budapest: Dante.

. 1962. Az orvosi hipnózis: I. P. Pavlov és a hipnózis: a pszichés befolyásolhatóság technikája [Medical hypnosis: I. P. Pavlov and hypnosis; The technique of psychological suggestion]. Budapest: Medicina.

Wolffram, Heather. 2009. The Stepchildren of Science: Parapsychology and Psychical Research in Germany, c. 1870-1939. Amsterdam and New York: Rodopi. 



\title{
Psychoanalysis in Representative Organs of the Hungarian Press between 1913 and 1939
}

\author{
Melinda Friedrich
}

Freud never wanted psychoanalysis to play any political role. However, politics has never been neutral to psychoanalysis. This becomes obvious if we look at the relationship of Hungarian newspapers to psychoanalysis from the latter's beginnings to its full institutionalization between 1913 and 1939. Supposedly, any newspaper from Berlin, Vienna, or Prague would be suitable for this purpose, as continental European journalism was known for its subjective style. Facts and events, social and cultural phenomena were not simply reported. They were commented and reflected on. Judgments were often formed according to the political philosophy of the given newspaper, even if censors restricted possibilities for the open expression of any organs' political aims. This suggests, furthermore, that the relation of newspapers to psychoanalysis can reveal how different segments of society related to psychoanalysis.

I have chosen a few Budapest newspapers: Pesti Hírlap, Pesti Napló, Népszava, and Budapesti Hírlap, and one journal, Színházi Élet, to investigate the presence of psychoanalysis in them. I hope to gain a picture of the position psychoanalysis occupied in pre-World War II Hungary by discussing the following questions:

(1) Which cases and which "extraordinary events" needed the opinion of a psychoanalytic expert?

(2) Which examples illustrate the distinct approaches of the different newspapers to the same case? 
(3) Who is a psychoanalyst in the different journals in Budapest before World War II? An expert? A charlatan? A doctor for everyone and every case? Or all these?

According to estimated circulation figures, one of the most read daily papers (besides Az Est [The Evening]) in the 1910s and in the 1920s was Pesti Hirlap (Pest Newspaper), which can be regarded as a moderately conservative organ. The second largest paper by circulation among the examined papers was Pesti Napló (Pest Daily), an old and influential daily paper, which was transformed into a left and literary journal by Lajos Hatvany in $1917 .{ }^{1}$ According to circulation data, Pesti Napló is followed by the conservative Budapesti Hírlap (Budapest Newspaper) and the social-democratic daily paper Népszava (People's Voice), which was the official organ of the Social Democratic Party of Hungary. Szinházi Élet (Theater Life) was a major weekly journal of the arts and theater (1912-1938) and a politically neutral, illustrated journal.

Psychoanalysis was present in all of these press organs, though most actively in Pesti Napló, which had both political and private reasons for its inclusion. The significantly higher number of mentions of psychoanalysis in Pesti Napló and Népszava also contributes to the fact that these papers were used by psychoanalytic circles as primary forums where information related to psychoanalysis was shared (e.g., psychoanalytic events and lectures were announced and discussed, and the consultation hours and addresses of psychoanalysts were publicized). It is obvious that certain newspapers had a more significant role in keeping psychoanalysis alive than others.

\section{Psychoanalysts on "Extraordinary Events"}

\section{PESTI NAPLÓ}

In 1924, Ferenczi reported to the presidents of the branch societies of the I.P.A. about the growing influence of the psychoanalytic movement and the public's rising interest in psychoanalysis in Hungary: "The interest in psychoanalysis among the educated classes is on the rise.... In extraordinary

${ }^{1}$ On Pesti Napló in the possession of Lajos Hatvany, see Lengyel 2006. 
events, e.g., criminal cases, the public (and the newspapers) are interested in the opinion of psychoanalysts" (Freud and Ferenczi 2000, 198). ${ }^{2}$

It was, in most cases, Pesti Napló which turned to psychoanalysts for expert advice on various matters. In a letter to Freud written on January 5 , 1930, Ferenczi referred to Pesti Napló as "one of the better Hungarian daily newspapers" and spoke of its editor as someone "who is not inimically disposed toward psychoanalysis and has already been of some service to us" (Freud and Ferenczi 2000, 379). Relatively regular contact between Ferenczi and the editor of Pesti Napló ${ }^{3}$ can be assumed, as Ferenczi also mentions a phone call by the editor in regard to the publication of Freud's new book.

Zsófia Dénes once described the different natures of Freud and Ferenczi as follows: "Freud is a serious, strict character, always a bit rigid and distant. Sándor Ferenczi is full of affability, a warm heart, and a wonderfully preserved, puerile spirit" (Dénes 1979, 52). This difference in their character becomes apparent in their respective relationship to the press: while Freud's attitude toward the press can be characterized by rejection and distance, Ferenczi was, unlike Freud, part of public life; he was present in the daily press and gave interviews to daily papers. ${ }^{4}$ Pesti Napló repeatedly invited him to give his expert opinion on questions concerning psychoanalysis: e.g., the charge of quackery in 1926 (R[áskay]. L. 1926, 4); the present and future of psychoanalysis (Csánk 1928, 38); Freud’s Goethe Prize in 1930 ("A legnagyobb német irodalmi díjat," 6); and on various social, cultural, and psychic phenomena from a psychoanalytic angle such as: "the new man of the world turned upside down after the war" (“A háború után” 1922, 6); the nervousness of Budapest

2 Psychoanalysts have always shown an interest in articles about psychoanalysis. Whatever was written about psychoanalysis was important, and they often sent each other newspaper clippings. One of the many examples for this we can find is in a letter from Ferenczi to Jones: "Here in Budapest, a nonsensical, confused, and malicious article, against Freud and for Adler, appeared in Pester Lloyd. . . It would be nice, and maybe effective, if you were to write a few lines to your friend J Vészi, editor-in-chief of $\mathrm{P}$ [ester] $\mathrm{Ll}$ [oyd], in connection with this [and kindly ask him not to just print any old nonsense sent to him about ps[ycho]an[alysis]" (Ferenczi and Jones 2013, 17).

3 Sándor Mester (1875-1958) was the chief editor of Pesti Napló at the time.

${ }^{4}$ It is worth mentioning here that Ferenczi had several journalists/writers among his friends (e.g., Sándor Bródy, Ignotus, Frigyes Karinthy, Dezső Kosztolányi, Gyula Krúdy) and one among his relatives (the niece of Ferenczi's wife, Zsófia Dénes, who worked for the radical Világ [World], and for a short period of time, Pesti Napló). 
("Nem is olyan ideges" 1923, 6); the soul of Americans ("A dollárláz" 1926, 9); girl suicides ("Leányöngyilkosságok" 1927, 4); and on certain criminal cases. ${ }^{5}$ The most popular psychoanalyst to be interviewed was Ferenczi. In case he was not available, Pesti Napló turned to his opponent, the Stekelian Sándor Feldmann. Feldmann was often interviewed about criminal cases, e.g., on the Düsseldorf monster 6 together with another active analyst, Imre Décsi ("A düsseldorfi rém" 1929, 6) or on the case of the female poisoners of Tiszazug, who were all examined by Feldmann in their cells ("A méregkeverőnők lelke" 1930, 5). Psychoanalysts who were guests in Budapest, like Georg Groddeck ("A lélek árnyékában" 1925, 4), August Aichhorn ("Léleknevelés - gyermeknevelés” 1925, 13), and Rudolf von Urbantschitsch (R[áskay]. L. 1925, 6) were also interviewed by Pesti Napló.

For Pesti Napló, psychoanalysts often gave their views on political topics. For example, Pesti Napló asked Ferenczi about the causes of the European depression and the influence of the political and financial situation on mental life, the indirect cause of which Ferenczi saw in the exaggerated idealism of the German volk ("Veszélyes ideálok" 1925, 9). During his stay in Budapest in 1934, Wilhelm Stekel was asked about the psychological background of dictatorships (“Az egyéni apa helyébe" 1934, 8).

The above articles show the variety of topics that required the opinion of a psychoanalytic expert and outline the domains psychoanalysis was able to cover at that time.

\section{NÉPSZAVA}

As for Népszava, it did not publish as many articles dealing with psychoanalysis as Pesti Napló. The work of Michael Bálint on the development of psychoanalysis (Bálint 1937, 39-40) is worth mentioning. Népszava interviewed Ferenczi in one case, when he expressed his views on clever horses ("A tudomány világából” 1912, 9). Visits, lectures, birthdays, and deaths of psychoanalysts were also covered by Népszava.

\footnotetext{
5 Ferenczi was sceptical about the use of psychoanalysis in this field, saying that "[p]sycho-analytic criminology has not evolved at all." According to him, "a real psychoanalyst does not speak about assumptions" (Szirmai 1930, 13). He obviously saw the limits of psychoanalysis.

6 The German serial killer Peter Kürten, charged with and tried for nine murders, was known as the Düsseldorf monster or the "Düsseldorf Vampire."
} 


\section{BUDAPESTI HÍRLAP}

Budapesti Hírlap asked for a psychoanalyst's expert opinion in one single case, when Ferenczi gave his views on sleeping and insomnia, a relatively neutral topic (Büky 1930, 10). The presentation of psychoanalysis as a form of charlatanism, a fashionable, invasive movement, a widespread humbug in Budapesti Hirlap shows the dominance of a negative attitude towards psychoanalysis (e.g., "Interju alvó emberekkel" 1934, 19). However, articles that acknowledged the merits of psychoanalysis can also be found (e.g., Sebestyén 1931; Kellner 1933).

\section{PESTI HÍRLAP}

The presentation of psychoanalysis by Pesti Hirlap provides, on the whole, a balanced picture. One can read articles representing different opinions on psychoanalysis, and the titles speak for themselves: "Budapest-the Psychoanalytic Capital of Europe" from 1923 (6) and "Dangerous Psychoanalysis" from 1926 ("Veszedelmes lélekelemzés" 1926, 8). In the latter article, psychoanalysis was attacked, described as "a typical product of the twentieth century," and accused of (and associated with) immorality. The article denied the scientific status of psychoanalysis, claiming that "[p]sychoanalysis is-a kind of scientific expressionism. And as for the so-called artistic movement, human beauty is not sacred, so for this 'scientific' movement, the human soul is no longer sacred and inaccessible" ("Veszedelmes lélekelemzés" 1926, 8). The paper did not publish any interviews with psychoanalysts with the exception of a short conversation with Ferenczi. In it, he spoke with a journalist from Pesti Hirlap in the hall of Hotel Hungaria about the goals of the visit of Marie Bonaparte, who spent a few days in Budapest in October 1927 ("Napóleon dédunokája" 1927, 4).

\section{SZÍNHÁZI ÉLET}

Psychoanalysts were present in Szinházi Élet not as experts per se, but rather as advisors in everyday matters. They were, in most cases, representatives of the Hungarian Stekelian group. Sándor Feldmann, the founder and leader of the Association of Independent Medical Analysts, gave his opinion on the truth-telling machine (“Orvosok, írók, színészek" 1933, 27) and examined furniture and colors for the home from a psychoanalytic perspective ("Színek, lakások, emberek" 1932, 203). Famous literary figures of the time like Thomas 
Mann, Gerhart Hauptmann, Vicki Baum, Sinclair Lewis, and Stefan Zweig, were analyzed by Stekel (Szinetár 1933, 18-19). Among other prominent people of the age, the daily routine of Sándor Ferenczi was described ("Nagy emberek" 1929, 22). At the end of 1932, Szinházi Élet launched a "Psychoanalytic school," which became very popular among the readers of the magazine ("Pszichoanalitikus iskola" 1932, 137). A remarkable member of the Stekelian group, Ernő Szinetár, led the school. He was an expert readers could turn to with any private problem. Additionally, there are many other psychoanalysis-related articles published in Szinházi Élet: the writings "Freudism on the Stage" (Szász 1919, 1-2); "What Is in the Depth of the Female Soul?" by writer Zoltán Szász (1920, 6-7); “Send Your Dream to Színházi Élet-Krúdy Gyula Is Going to Interpret It” ("Látogatás az Álomfejtőnél” 1921, 13-14); "Miss Margaret Severn, ${ }^{7}$ a Famous Dancer from New York is Looking for a Partner in Budapest" (1926, 28-29); and "Fantastic Drawings on Manuscripts of Famous Writers: Hollós ${ }^{8}$ on the Psychology of Manuscripts" (1927, 36-37), just to mention a few. The titles suggest the presentation of psychoanalysis in a more popular format.

\section{Concrete Examples}

\section{THE ROLE OF PSYCHOANALYSIS IN REPORTS ON THE KORNIS CASE}

In 1927, the criminal case of a pseudo-psychoanalyst named Ignác Kornis was eagerly discussed in Hungarian newspapers. He was called the "Kolumbus Street Blackmailer." He lured a rich merchant to an abandoned villa on Kolumbus Street, where he tied him up and demanded his money. As the merchant was not able to meet his demand, the doctor drove him to a bank. In the car, the doctor threatened the merchant with a revolver. At the entrance of the bank, he finally let the scared man go.

A few months later, the doctor turned up in the editorial office of Die Rote Fahne in Vienna, where he introduced himself and came forward with

\footnotetext{
7 Margaret Severn was the daughter of Ferenczi's patient, and later a psychoanalyst in her own right, Elizabeth Severn.

8 István Hollós, psychiatrist and psychoanalyst, was a founding member of the Hungarian Psychoanalytic Association.
} 
the proposal to organize rebellions in Hungary and-if he got some assistance-to blow up the Weisz Manfréd factory in Budapest. He aroused the suspicion of the Viennese police and was immediately identified and caught by the Hungarian police. After a ten-minute medical examination he was declared mentally ill and was taken to the Angyalföld mental hospital and later to the Lipótmezö facility. The doctor said he had been conducting a psychological experiment on himself and wanted to examine people on psychoanalytic grounds. The events of the Kornis case were reported in detail by all Hungarian newspapers. Below is a representative sample of the role of psychoanalysis in reports on the Kornis case:

"Quackery or psychoanalysis? Ignác Kornis, the fantastic quack, fake communist, blackmailer, criminal shrink, Kolumbus street blackmailer, and neurologist made a confession" ("Szélhámosság vagy pszichoanalízis" 1927, 9).

"The psychoanalytic field trip of Kornis" ("Összeomlott az óriási kommunista összeesküvés" 1927, 4).

"Blackmailing on the basis of Freud's theory" ("Nagyszabásu kommunista szervezkedést” 1927, 12).

"As a follower of Freud's theory, he wanted to investigate the excitement evoked in his soul by such a crime" ("Megvizsgálják a Kolumbusz-utcai" 1927, 10).

"The ambulance left for the mental hospital in Angyalföld with Ignás Kornis, who seems to have got off lightly for psychoanalytic blackmailing” (“Elmegyógyintézetbe vitték" 1927, 9).

"The Kolumbus street 'psychoanalytic' blackmailer"; "the psychoanalyst under arrest" ("Dr. Kornis Ignácot” 1927, 6).

"The psychoanalytic offender of the Kolumbus street outrage" "Kalandorregény vagy epilepszia” 1929, 11).

It is striking how often Freud's name and the words "psychoanalysis" and "psychoanalyst" were used in connection with the case of Kornis, primarily 
by Pesti Hirlap and Budapesti Hírlap. Dr. Kornis himself had repeatedly been defined as a psychoanalyst. Only the readers of Pesti Napló had the possibility of learning about the professional identity of Dr. Kornis by an authentic psychoanalyst. It was the Stekelian Sándor Feldmann, formerly expelled from the Freudian society, ${ }^{9}$ who clarified the role of psychoanalysis in the case and called attention to the importance of maintaining a united organization of highly trained psychoanalysts: "It is impossible and annoying that today each and everyone calls himself a psychoanalyst. A huge camp of wild analysts, pirate-analysts, and quack analysts has started to overrun the sick society, thus discrediting honorable, trained medical and lay analysts, who formed themselves into moral organizations" ("Mit mondanak az idegorvosok" 1927, 12). Feldmann pointed out that there were two associations which provided a kind of legitimation of the work of a psychoanalyst: the International Psycho-Analytical Association under Freud's leadership and the Association of Independent Medical Analysts helmed by Stekel. These were morally responsible for the activity of their members. Feldmann concluded that "Dr. Kornis belonged to none of these associations, his case is, therefore, only the case of the police, not that of psychoanalysis" ("Mit mondanak az idegorvosok" 1927, 12).

The question "Quackery or Psychoanalysis?" raised by Pesti Napló, did not arise in Pesti Hirlap and Budapesti Hirlap at all. But by their identification of Kornis as a psychoanalyst, and through their overemphasis on the role of analysis in the case, the unfriendly attitude of conservative organs towards psychoanalysis became visible.

"Fool, Agent Provocateur, or Psychoanalyst?" was the title of a report on Kornis in an Austrian paper ("Narr, Lockspitzel" 1927, 1). I suspect the same conclusions can be drawn if we take a look at the presentation of the Kornis case by newspapers in another European capital, Vienna, where the case also created a sensation. Kornis was declared "a 'psychoanalytic' specialist of the communists" by Reichspost ("Kommunistenrazzia in Ungarn" 1927, 1); "an agent provocateur of Horthy" by Rote Fahne ("Der Horthy-Agent" 1927, 3); and "a communist plotter" by Das kleine Blatt, which published its report on the Kornis case with the title "Psychoanalysis" ("Psychoanalyse" 1927, 4). The role of psychoanalysis in the case was cleared up by some (but not all) of the papers. In the end, the Social Democratic Arbeiter-Zeitung's headline,

9 On Feldmann's exclusion from the Freudian Society and the relation of Ferenczi to him see Hárs 2007. 
"Only Swindler, without Psychoanalysis" sums up the case ("Nur Schwindler" 1927, 3). Unlike the Hungarian press, no psychoanalyst was asked by Austrian newspapers to clarify the professional identity of Kornis.

All the above examples suggest that the political direction of the reporting newspaper was a determining factor in the presentation of this case.

\section{PSYCHOANALYSIS AT THE CONGRESS \\ OF HUNGARIAN PSYCHIATRISTS}

The contrast between the different perspectives of newspapers can also be observed in three different reports on the same event, the 1926 Congress of Hungarian Psychiatrists.

The report of Budapesti Hirlap put emphasis on the facts of the debate: in the subheading we can read: "Dispute about the Acknowledgement of Psychoanalysis" (“Az elmeorvosok értekezeletének záróülése” 1926, 7). Pesti Hirlap commented on the event more favorably in its article "The Congress of Hungarian Psychiatrists Finished," underlining the significance of "the first appearance of psychoanalysts at the podium of the psychiatrists' congress" ("Befejezték" 1926, 7). Support of psychoanalysis was evident already in the title of the Pesti Napló article: "Psychoanalysis Made Its Debut at the Congress of Hungarian Psychiatrists." The event was celebrated by Pesti Napló as the passage of psychoanalysis into the ranks of official medicine ("Nagy viharok között" 1926, 7).

\section{"IN BERLIN YOU CAN BE ANALYZED FOR ONE MARK"}

The image of psychoanalysis in Berlin can also serve as an example of the contrast between the perspectives of the liberal and the conservative press.

Pesti Napló reported the success of the Berlin Psychoanalytic Institute, which moved to a large building at 10 Wichmanstrasse in the autumn of 1928. Eitingon was asked about the relocated Poliklinik, and the flourishing of psychoanalysis in Berlin was described: "Every German citizen, whether he/she has money or not, can make use of the help of the institute on Wichmannstrasse, and the figures serve as a proof that there are more and more people who hope to be healed with this help" ("Megnyílt Berlinben” 1928, 8). The article, "Berlin, the Mecca for Charlatans and Fortune-Tellers" in Budapesti Hirlap from 1932 suggested that a psychoanalyst was something like an astrologist or a fortune-teller on the street. With the statement " $t$ the psycho- 
analyst took up the role of Shaman of primitive peoples" ("Berlin" 1930, 7), readers were warned against psychoanalysis, which was presented as a form of charlatanism, and as an illegitimate and dangerous form of therapy.

\section{The Image of the Psychoanalyst in the Various Press Organs}

In Pesti Napló and Népszava, the emphasis was placed on the professional attributes of the psychoanalyst: he/she appears in these newspapers as an expert (mostly a scientist or a doctor) and a competent person whose judgment matters and whose professional opinion is trustworthy.

In the conservative press (primarily Budapesti Hirlap), the psychoanalyst was generally presented as an unreliable charlatan apart from a few exceptions. Articles mentioning psychoanalysis often included warnings against its theory and practice.

In Szinházi Élet, we see psychoanalysis in its popular form, dominated by representatives of the Hungarian Stekelian group. Any reader of the journal must have been interested in the psychoanalysis of famous writers by Stekel and could potentially turn to Ernő Szinetár’s Psychoanalytic School. Színházi Élet made psychoanalysis easily accessible to everyone.

Pesti Napló, Népszava, and Szinházi Élet provided psychoanalysis with moderate support, while Pesti Hírlap showed reservations about the Freudian science, and Budapesti Hirlap was openly malicious towards it in several cases. However, this hostile attitude toward psychoanalysis was not as harmful as silence might have been. In his work on the social representations of psychoanalysis in France, Moscovici underlined the importance of any presence of psychoanalysis in the press: "[Psychoanalysis] fills space, attracts attention and offers a new terminology, but this does not mean that it is discussed seriously or on its own terms. Psychoanalysis, like 'blood on the front page,' 'horoscopes' and 'gossip', is something that sells newspapers. Whether it is discussed in sympathetic or unsympathetic terms does not matter: all that matters is getting people to talk about it" (Moscovici 2008, 241).

The heterogeneous portrait of psychoanalysis that we encounter in various press organs may help us imagine what psychoanalysis was and what being a psychoanalyst meant in pre-World War II Budapest. After all, Ferenczi was right when he wrote to Freud in 1914: "They are talking about us a lot... in Hungary” (Freud and Ferenczi 1993, 541). 


\section{REFERENCES}

"A dollárláz: az amerikai lélek menekülése a belső konfliktusok elől. Dr. Ferenczi Sándor Amerika lelkéről és a pszichoanalízis új eredményeiről" [The dollar-fever: The escape of the American soul from inner conflicts; Dr. Sándor Ferenczi on the soul of America and the recent results of psychoanalysis]. 1926. Pesti Napló 262 (November 18): 9.

"A düsseldorfi rém. Idegorvosok a tömeggyilkos lelkéről" [The monster of Düsseldorf: Psychiatrists about the soul of mass-murderers]. 1929. Pesti Napló 262 (November 17): 6.

"A háború után felfordult világ új embere társadalomtudományi, rendőri, lélekelemzési és asszonyi megvilágításban" [The new man of the world turned upside down after the war from the perspective of social sciences, policemen, psychoanalysis, and women]. 1922. Pesti Napló 88 (April 19): 6.

"A legnagyobb német irodalmi díjat kapta meg Freud. Dr. Ferenczi Sándor a 75 éves Freudról" [Freud was given the greatest literary prize: Dr. Sándor Ferenczi on the 75-year-old Freud]. 1930. Pesti Napló 176 (August 5): 6.

"A lélek árnyékában..." [In the shadow of the soul...]. 1925. Pesti Napló 261 (November 18): 4.

"A méregkeverőnők lelke" [The soul of female poisoners]. 1929. Pesti Napló 281 (December 10): 5 .

"A tudomány világából. Az okos lovak" [From the world of science: Clever horses]. 1912. Népszava 278 (November 23): 8-9.

“'Az egyéni apa helyébe a kollektív vezér lép—mert a szülő elvesztette tekintélyét.' Beszélgetés a Budapestre érkezett Stekellel, a híres bécsi idegorvossal a diktatúrák lelki alapjairól" ["The collective leader takes the place of the individual father": Conversation with Stekel, the famous psychiatrist from Vienna who arrived to Budapest, about the psychological background of dictatorships]. 1934. Pesti Napló 23 (January 30): 8.

"Az elmeorvosok értekezletének záróülése" [The closing session of the congress of psychiatrists]. 1926. Budapesti Hírlap 255 (November 10): 7.

Bálint, Mihály. 1937. "A lélektudomány fejlődése" [On the development of psychoanalysis]. Népszava 293 (December 25): 39-40.

"Befejezték a magyar elmeorvosok országos kongresszusát" [The nationwide congress of Hungarian psychiatrists concludes]. 1926. Pesti Hírlap (November 10): 7.

"Berlin, a jósok és kuruzslók Mekkája” [Berlin, the Mecca for charlatans and fortunetellers]. 1932. Budapesti Hírlap 71 (March 30): 7.

"Budapest-Európa lélekelemző fövárosa" [Budapest-the psychoanalytic capital of Europe]. 1923. Pesti Hírlap 205 (September 13): 6.

Büky, György. 1930. “Tanuljunk meg aludni-Mit mond az orvostudomány az alvásról?" [Let us learn to sleep: What does medicine say about sleeping?]. Budapesti Hírlap 191 (August 24): 10.

Csánk, Endre. 1928. “Ha majd eltüntetjük az emberi jellem hibáit... Beszélgetés Ferenczi Sándorral a pszichoanalízis jelenéről és jövőjéről s a lélek térképének 'fehér foltjairól,' amelyek nem fehér foltok többé" ["If we once remove the faults of 
human character. . .": A conversation with Sándor Ferenczi about the present and future of psychoanalysis and about "blank areas" on the soul's map, which were not blank areas any more]. Pesti Napló 153 (July 5): 38.

Dénes, Zsófia. 1979. Szivárvány Pesttől Párizsig [Rainbow from Budapest to Paris]. Budapest: Gondolat.

"Der Horthy-Agent Dr. Kornis ist auch ein Erpresser. Da er aber ein agent provokateur ist, lässt ihn die Budapester Polizei laufen.” 1927. Die Rote Fahne (August 16): 3.

"Dr. Kornis Ignácot elmeorvosok fogják megvizsgálni” [Dr. Ignác Kornis will be examined by psychiatrists]. 1927. Pesti Hírlap 201 (September 6): 6.

"Elmegyógyintézetbe vitték a Kolumbusz-utcai zsarolót" [The Columbus street blackmailer was taken to mental hospital]. 1927. Budapesti Hírlap 202 (September 7): 9.

"Fantasztikus rajzok, híres írók kézirat-papirosán. Hollós főorvos nyilatkozik a kézirat lélektanáról" [Fantastic drawings on manuscripts of famous writers: Hollós on the psychology of manuscipts]. 1927. Színházi Élet 26: 36-37.

Ferenczi, Sándor, and Ernest Jones. 2013. Letters 1911-1933. Edited by Ferenc Erős, Judit Székács-Weisz, and Ken Robinson. London: Karnac Books.

Freud, Sigmund, and Sándor Ferenczi. 1993. The Correspondence of Sigmund Freud and Sándor Ferenczi. Vol. 1, 1908-1914, edited by Eva Brabant, Ernst Falzeder, and Patrizia Giampieri-Deutsch. Cambridge, MA: Harvard University Press.

Hárs, György Péter. 2007. “A bécsi és a budapesti Stekel arcai a Freud-Ferenczi levelezésben" [The faces of the Viennese and Budapestian Stekel in the correspondence between Freud and Ferenczi]. Thalassa 2-3: 97-120.

"Interju alvó emberekkel. A freudizmus áldozatai" [Interviews with sleeping men: Victims of Freudism]. 1934. Budapesti Hírlap 41 (February 21): 19.

"Kalandorregény vagy epilepszia. Hajós professzor a düsseldorfi esetről” [Adventure novel or epilepsy: Professor Hajós about the Dusseldorf case]. 1929. Budapesti Hírlap 268 (November 4): 11.

Kellner, Dániel. 1933. "Pszichoanalízis a rendelőkben és a szalonokban” [Psychoanalysis in consulting rooms and saloons]. Budapesti Hírlap 177 (August 6): 7.

"Kommunistenrazzia in Ungarn. Massenverhaftengen. Eine 'psychoanalytische' Spezialität der Kommunisten.” 1927. Reichspost 241 (September 4): 1.

“Leányöngyilkosságok” [Girl suicides]. 1927. Pesti Napló 236 (October 18): 4.

"Léleknevelés - gyermeknevelés. Beszélgetés August Aichhornnal, a pszichoanalízis első pedagógusával" [Soul education-child rearing: A conversation with August Aichhorn]. 1925. Pesti Napló 293 (December 29): 13.

Lengyel, András. 2006. "Hatvany Lajos Pesti Naplója (1917-1919)" [The Pesti Napló of Hatvany Lajos]. I. Magyar Könyvszemle 4, no. 122: 444-63.

“Megnyílt Berlinben a pszichoanalízis új főiskolája. Dr. Eittington [sic] igazgató a freudisták világszervezetéröl" [In Berlin the new college of psychoanalysis opened: Director Dr. Eittington on the world organisation of Freudians]. 1928. Pesti Napló 249 (November 3): 8.

"Megvizsgálják a Kolumbusz-utcai zsaroló elmeállapotát" [The state of mind of the Columbus street blackmailer is examined]. 1927. Budapesti Hírlap 201 (September 6): 10.

“Miss Margaret Severn, egy híres newyorki táncosnő Budapesten keres partnert magának" [Miss Margaret Severn, a famous dancer from New York is looking for a partner in Budapest]. 1926. Színházi Élet 31: 28-29. 
“Mit mondanak az idegorvosok dr. Kornis “tudományos” kísérletéről?” [What do psychiatrists say about the "scientific" experiment of Dr. Kornis?]. 1927. Pesti Napló 200 (September 4): 12.

Moscovici, Serge. 2008. Psychoanalysis: Its Image and Its Public. Cambridge: Polity Press.

"Nagy emberek 24 órája” [24 hours of great people]. 1929. Színházi Élet 12: 22.

"Nagyszabásu kommunista szervezkedést leplezett le a rendőrség és közben elfogta a Kolumbus uccai zsarolót. Zsarolás a Freud-elmélet alapján” [The police uncovered a broad-scale communist movement and caught the Columbus street blackmailer: Blackmailing on the basis of Freud's theory]. 1927. Budapesti Hírlap 200 (September 4): 12.

"Nagy viharok között vonult be a pszichoanalízis a hivatalos magyar orvostudományba" [The stormy marching in of psychoanalysis into official medicine]. 1926. Pesti Napló 255 (November 10): 7.

"Napóleon dédunokája, a pszichoanalízis tudósa" [Napoleon’s great-granddaughter, scientist of psychoanalysis]. 1927. Pesti Hírlap 235 (October 6): 4.

"Narr, Lockspitzel oder Psychoanalytiker? Eine seltsame Verhaftung in Budapest." 1927. Reichspost 241 (September 5): 1.

"Nem is olyan ideges ez a Pest" [Pest is not so nervous]. 1923. Pesti Napló (February 18): 3 .

"Nur Schwindler-ohne Psychoanalyse." 1927. Arbeiter-Zeitung 243 (September 6): 3.

"Orvosok, írók, színészek, az egész felháborodott társadalom tiltakozik az igazmondó gép ellen" [Doctors, writers, actors/actresses, the whole outraged society protests against the truth-telling machine]. 1933. Színházi Élet 36: 26-28.

“Összeomlott az 'óriási kommunista összeesküvés' meséje. Kornis Ignácnak semmi köze a kommunistákhoz" [The tale of the "great communist plotting" collapsed; Ignác Kornis has nothing to do with communists]. 1927. Népszava (September 6): 4.

“Psychoanalyse.' Das Attentat in der Kolumbusgasse." 1927. Tagblatt 203 (September 6): 4.

"Pszichoanalitikus iskola" [Psychoanalytic school]. 1932. Színházi Élet 52: 137-40.

R[áskay], László. 1925. "Beszélgetés Urbanschich [!] Rudolffal, a pszichoanalitikai nevelésröl” [A conversation with Rudolf Urbanschich (sic) about psychoanalytic child rearing]. Pesti Napló 68 (March 24): 6.

— 1926. "Kuruzslás-e a pszichoanalízis, ha nem orvos alkalmazza?” [Is psychoanalysis quackery if applied by a non-doctor?]. Pesti Napló 157 (July 15): 4.

Sebestyén, Károly. 1931. "Freudizmus és politika" [Freudism and politics]. Budapesti Hírlap 190 (August 23): 9.

Szász, Zoltán. 1919. "Freudizmus a színpadon” [Freudism on the stage]. Színházi Élet 49: $1-2$.

— 1920. "Mi van a női lélek mélyén?" [What is in the depth of the female soul?]. Színházi Élet 46: 6-7.

"Szélhámosság vagy pszichoanalízis? Kornis Ignác, a fantasztikus szélhámos, mü-kommunista, bünügyi lélekbúvár, Kolumbus-uccai zsaroló és idegorvos beismerő vallomást tesz" [Quackery or psychoanalysis? Ignác Kornis, the fantastic quack, fake-communist, blackmailer, criminal shrink, Columbus street black- 
mailer and neurologist made a confession]. 1927. Pesti Napló 200 (September 4): 9-10.

“Színek, lakások, emberek” [Colors, flats, humans]. 1932. Színházi Élet 52: 203-204.

Szinetár, György. 1933. "Jön az 'abszolut' Molnár-darab!-jelenti Wilhelm Stekel, a világhírű pszichoanalitikus orvostanár" [“The 'absolute’ Molnár-play is coming!"” reports Stekel, the world-famous psychoanalytic doctor and teacher]. Színházi Élet 11: 18-19.

Szirmai, Rezső. 1930. "Mademoiselle X, a kriminológia, az orvostudomány és a pszichoanalízis fantasztikus rejtélye" [Mademoiselle X: The fantastic mystery of criminology, medicine, and psychoanalysis]. Pesti Napló 95 (April 27): 13.

"Veszedelmes lélekelemzés" [Dangerous psychoanalysis]. 1926. Pesti Hírlap 11 (January 15): 8.

"Veszélyes ideálok. Dr. Ferenczi Sándor a mai Európa lelki csődjéről” [Dangerous ideals: Sándor Ferenczi on the psychic bankruptcy of today's Europe]. 1925. Pesti Napló 116 (May 24): 9. 


\title{
Alice Bálint at the Intersection of the Personal, the Professional, and the Political
}

\author{
Anna Borgos
}

\section{Introduction: Women in Psychoanalysis}

Psychoanalysis seemed to be a relatively accessible path for women in the early twentieth century. The proportion of women in the profession at the time was, on an international level, higher than in any other field of science (Appignanesi 2000; Thompson 1987; Zaretsky 2005). In the 1930s in Europe, 30 percent of psychoanalysts were women while they composed only 5 percent of medical practitioners (Freidenreich 2002; Borgos 2017 and 2018). In Vienna between the 1910 and 1937, women's participation had increased from 2 percent to 45 percent (Mühlleitner 2000). This tendency is reflected in the membership of the Hungarian Psychoanalytic Association as well; fifteen percent of its members were female in the 1920s, rising to more than 30 percent in the 1930s, and reaching nearly 48 percent by 1937 (see Giefer 2007). ${ }^{1}$

1 In detail:

- 1913: 5 men, 0 women (0\%)

- 1921: 16 men, 2 women (Kata Lévy, Erzsébet Révész-Radó) (11\%)

- 1929: 12 men, 5(-1) women (+Alice Bálint, Margit Dubovitz, Vilma Kovács, -Erzsébet Révész-Radó) (25\%)

- 1937: 13 men, 12 women (+Edit Gyömrői, Lilly Hajdu, Fanny Hann-Kende, Klára Lázár-Gerő, Lucy Liebermann, Lillián Rotter, Lilla Wagner) (48\%)

It makes the calculation difficult that, especially in the few years following its establishment, not all members of the society were trained analysts. Among its members we can find philosophers, literary critics, poets, lawyers, an economist, and a brewer too; some of them were trained, while others were just supporters or "fans" of psychoanalysis. 
Although psychoanalytic institutions were mainly led by men, from the 1920s on, more and more women filled leading positions in the movement as training analysts, editors, and professors. Many of these women achieved status in the profession or enhanced their academic reputations in the 1930s, as a result of their emigration to Britain or the United States (Roith 1988; Roudinesco 2000).

If one tries to find the roots of the relatively strong presence of women in psychoanalysis, one may consider a set of factors: on the one hand, the expansion of the analytic profession happened at a time when women's social opportunities were broadening in general in the fields of education and work. On the other hand, marginalized groups in society usually have more opportunities to enter emerging professions, as they set less rigid professional and gender hierarchies. The need to abandon traditional paths is a common feature of the history of both intellectual women and psychoanalysis. Furthermore, psychoanalysis involves values such as empathy, intimacy, and emotionality, which are traditionally associated with femininity, thus it is capable of incorporating both traditional and modern women's roles.

Early women psychoanalysts were in a special situation since they were both dependent and privileged. This also influenced their institutional positions: they generally served as therapists, trainers, translators, organizers, or mediators and were less visible as theoretical or organizational leaders, with the exception of a few significant "token women" like Helene Deutsch, Anna Freud, and Melanie Klein. Hungarian women analysts had important masterdisciple relationships with Ferenczi, which seems to have been somewhat more equal as compared to the scientific hierarchy in Viennese psychoanalytic circles. $^{2}$ A loose female circle developed around the child psychology seminars held by Alice Bálint, Lillián Rotter, and Edit Gyömrői for pedagogues and mothers, and the analyst-analysand relations indicate a "matrilinear" tendency around Vilma Kovács, who trained Lilly Hajdu, Alice Hermann, and Erzsébet Kardos.

One important question is whether there were any special characteristics of women analysts' life and work within the broader history of psychoanalysis in terms of their social background and opportunities, positions, ex-

2 Ferenczi's progressive views on women's issues and sexuality are represented, for instance, in Ferenczi 1906 and Ferenczi 1908. 
periences, professional fields and perspectives, their therapeutic attitudes, or reception.

There were some common features of the socio-cultural background of Hungarian women analysts. They came from educated, mostly converted Jewish middle-class families, and their parents/fathers were intellectuals or traders. In the case of assimilated, middle-class Jews, there was, apparently, greater openness towards modern women's roles and also greater social mobility (Karady 2004). Emancipation in religion and gender roles was equally influential. From another angle, Jewishness, womanliness, and psychoanalysis all involved simultaneous assimilation and marginalization.

The majority of Hungarian women analysts received university degrees in medicine or the humanities, but some were so-called "lay" analysts without a diploma, and a few of them also joined or were influenced by the progressive social and intellectual movements of their age. As for their family lives, they lived in apparently equal, companionate relationships, often sharing their professional interests with their partners. "On average," these analysts had one or two children, that is, less than the average of the age.

Even if they themselves were usually apolitical, their lives, similarly to their male colleagues, were heavily influenced by politics, including two major waves of emigration (Mészáros 2014). In 1919, after the collapse of the shortlived Soviet Republic, many of them escaped from the retributory political climate, but also had the intention to continue their studies, mostly in Vienna or Berlin. The Berlin Psychoanalytic Institute was a major center for emigrant analysts between 1920 and 1933 (Danto 2005). After 1938, emigration was clearly a flight from the persecution of Jews who were facing an existential threat, and many went into exile in England, the United States, or Australia. Displacement did not only mean geographical migration for them, but also involved shifts in scientific views, social circumstances, languages, professions, or family situations.

If we explore the professional specializations of early Hungarian female analysts, gender seems to be a significant factor. Their activities were mostly related to theories of femininity, child-analysis, or the early mother-child relationship, such as the work of Alice Bálint, Lillián Rotter, and Margaret Mahler. This tendency represents women's position in the division of social roles well. Yet as one of the most central and constitutive subjects in psychoanalysis, we cannot call it an especially "feminine" interest, or rather, we must extend it to the entire realm of psychoanalysis (Moi 1996; Gilman 1991; 
Felski 1995). ${ }^{3}$ Freud's primary texts on femininity were soon followed up with comments from his colleagues and disciples. From the 1910s on, femininity became a significant sub-discourse within psychoanalytic theory. On the other hand, the scope of Hungarian women's scholarly activity included several other fields, like the study of schizophrenia (Lilly Hajdu), ethno-psychology (Alice Bálint), and the development of the system of training analysis (Vilma Kovács). These analysts most typically held the position of therapist, organizer, mediator, trainer, or psychoanalytical promoter. After World War II, a few of them took up leading institutional positions, though not in the field of psychoanalysis.

Nancy Chodorow's interviews with early women analysts in the 1990s suggest that their gender was not as influential as their professional or, later on, (due to external labeling) their Jewish identity (1989). However, women's memoirs and correspondence (like those of Edit Gyömröi, Alice Bálint, Lilly Hajdu, Margaret Mahler, and Helene Deutsch) seem to contradict or at least nuance this picture. Questions of gender, family, and motherhood are repeatedly articulated in these texts. In the case of Anna Freud, Helene Deutsch, and Therese Benedek, it is remarkable to confront their conservative psychoanalytic views on gender roles in light of their own career trajectories. Nevertheless, gender cannot be considered an absolute and ahistoric category, but as a factor embedded in actual social conditions. The "reception" of womanliness, Jewishness, and psychoanalysis was equally burdened with tension in the twentieth century. At the same time, all of these categories also involved the benefits of emancipation and creativity. The respective careers of these early female analysts are thus situated at the complex intersection of racial, gender, social, and professional identities.

In the next part of this chapter, through the example of the early Hungarian female analyst Alice Bálint, I explore the relationship between the psy-

3 In psychoanalysis or in the attitudes towards it, one can recognize certain motifs of "femininity." This is the language of the "other," a taxonomically unclassifiable entity. According to the positivist concept of science, it is considered unscientific and peripheral, to be excluded and "discriminated" against; at the same time, it has been constructed through this exclusion-a reminder of the position of femininity. On the other hand, (Freudian) psychoanalysis is prone to consider itself the depository of "masculine" scholarship. Quoting Toril Moi $(1990,196)$, "psychoanalysis is born in the encounter of the hysteric woman and the positivist man of science." On similar parallels between Jews and women, see, e.g., Gilman 1991. On the "female" nature of modernity, see Felski 1995. 
choanalytic profession, gender, and historical context, through material from in her recently discovered notebooks. ${ }^{4}$

\section{Alice Bálint: A Biographical Overview}

Alice Bálint (born Székely-Kovács) (Dupont 1992, 2002a, 2002b, 2012, 2015; Harmat 1994) was the daughter of Vilma Kovács, one of the very first female analysts and the creator of the Hungarian system of training analysis (Kovács 1936). During her short life (she died when she was forty-one), she had a very robust theoretical, therapeutic, and educational life. Using a contemporary term, she can be characterized by her interdisciplinarity; in addition to psychoanalysis, she was engaged in the equally new science of ethnology and cultural anthropology, which she could successfully integrate into her analytic thought. Similarly influential were her (reform) pedagogic connections in child psychology, that is in the viable and effective pedagogic application of psychoanalysis. With the new approach of the mother-child relationship, which she considered an active love relationship or a "primary object-love" from its beginning, she became one of the forerunners of the object relation theory.

Alice Bálint was born in Budapest in 1898. She was a high school classmate of Emmi Bergsmann (the sister of Mihály Bálint) and Margit Schönberger (known as Margaret Mahler). She studied mathematics at the Faculty of Philosophy (1916-1919), but she already had an interest in anthropology, economics, and psychoanalysis. However, as her future husband mentioned in his interview, for some reason she did not attend Ferenczi's 1919 university lectures. In 1920, she completed two semesters at the Faculty of Law (in the political science department) of the University of Vienna.

4 In 1984, Michael Bálint's widow, Enid Bálint, left the biographical and professional documents of Michael, Alice, and Enid Bálint to psychoanalyst André Haynal. These were available in the Geneva Medical University by 2014. André Haynal (1988) largely relies on these materials. In 2014, the documents were transported to London and deposited in the Archives of the British Psychoanalytical Society. The thirteen notebooks from 1917-1929 (including a recipe booklet) are part of the materials from or about Alice Bálint. I would like to thank sociologist Ágnes Földházi for access to the archive in Geneva. 
She and Mihály Bálint already knew each other from high school, but they got into closer contact in 1918, and this proved to be a life-long, mutually influential relationship both emotionally and intellectually. Mihály Bálint recalled the time and significance of their encounter:

Then, in 1918-that is very important-I fell in love with my wife. We were both students. She studied mathematics. Both of us were interested in analysis also, although she didn't come to Ferenczi's lectures. I really do not know why not. She gave me, lent me Totem and Taboo.... Her real field was anthropology, and Totem and Taboo was one of the fundamental books in it. . . She was this kind of human being, like me, interested in everything, she studied mathematics as well. (Swerdloff 1965, 386-87)

After their marriage in 1921, they moved to Berlin (Vogelsänger 2010). Professional training as well as flight from the anti-Semitic atmosphere in Hungary motivated their travel. ${ }^{5}$ Alice Bálint went to the political sciences department of Friedrich-Wilhelm University (1921-1923), studied ethnology, and worked at the Museum für Volkerkunde (anthropological museum). She became an extraordinary member of the Berlin Psychoanalytic Association and gave lectures at the society. Mihály Bálint graduated in chemistry and worked at the Berlin Psychoanalytic Institute.

In 1922, the couple began analysis with Hanns Sachs, but they were unsatisfied with his overly theoretical sessions. Alice Bálint gave a few lectures at the Berlin Psychoanalytic Association on female psychosexual development, Mexican war hieroglyphs (Bálint 1923), and South-Californian and Indian myths. ${ }^{6}$

It was not an easy period in her life. Alice's diary demonstrates the psychic difficulties of the inner travel and displacement she had gone through. It is remarkable how her worry about Mihály's future is formulated; it sounds as

\footnotetext{
5 This direct threat is indicated by Imre Hermann's recollections of the times after the fall of the Soviet Republic: "Bálint was forced to seek refuge at the university apartment of one of the professors" from the atrocities of the Awakening Hungarians' commandos (Hermann 1974, 45-47).

6 The list of lectures can be found in a detailed Alice Bálint bibliography (possibly compiled by Michael Bálint). BPS Archives, London.
} 
if psychoanalysis was only his business. She also felt anger towards her husband for his lack of (personal? professional?) maturity.

I'm sitting now in Berlin; it's cold and raining. I'm walking this tightrope on and on. I've finished my analysis, it was a great lesson for me, but has not ceased to puzzle me. On the contrary, it has unveiled my pseudo-security and sentenced me to seek and struggle again.... And there is the trouble, the biggest trouble of all, with Misi and his future: analysis. And there is an anger here too for he has not waited for me as a ready and complete person, but he is giving himself to me again as an immature child. (June 21, 1923)

In 1924, the couple returned to Budapest and finished their analysis with Ferenczi. In 1925, Alice enrolled at Ferencz József University in Szeged, and she studied geography for one semester. In 1925, their son János was born, and she reports on his development in her notebooks with photographs between 1925 and 1936, and probably built these observations into her theory on the early mother-infant relationship. She became an active member of the Hungarian association in 1926, she was elected to the training committee and worked in the Polyclinic, the public and free ambulant psychotherapeutic clinic for adults and children (opened in 1931, headed by Ferenczi and after his death by Mihály Bálint), and she also maintained a private practice. She held courses in psychoanalytic child-psychology for pedagogues and parents, presented at seminars and congresses, and published regularly. ${ }^{7}$ She focused mainly on issues related to child psychology. She, like her husband, saw the mother-child relationship as a primary object relationship in which the infant also actively takes part. She pointed out the relationship between infants' bodily development and their emotional environment (Bálint 1931). ${ }^{8}$ Her anthropological readings also persuaded her that there is no universal

${ }^{7}$ Her papers were published in Internationale Zeitschrift für Psychoanalyse, Imago, Zeitschrift für Psychoanalytische Pädagogik as well as in Hungarian pedagogical journals such as Gyermeknevelés [Child Rearing] and A Jövő Útjain [On the Paths of the Future].

8 Alice Bálint published these ideas in her 1931 book A gyermekszoba pszichológiája [The Psychoanalysis of the Nursery]. The book was translated into four languages (German, French, Spanish, and English) by Michael Bálint who also wrote the introduction, and the American edition included a foreword by Anna Freud. 
or "natural" form of child rearing (Danto 2005, 276). ${ }^{9}$ At the same time, she did not consider repression an unnatural and necessarily painful process, provided that parents support it by preparing the child for reality not through their authority but rather through authenticity and sincerity. Alice Bálint's educational and consultative activity was also remarkable; in her answers to parents' questions, she also wrote about various taboo issues such as onanism, sex education, etc. ${ }^{10}$

The leftist and Jewish majority of analysts and psychoanalysis itself were equally "suspicious" and dangerous in the eyes of the political authorities during the 1920s and 1930s. As Michael Bálint recalled:

We were very squeezed in the University, under the Horthy regime and all the anti-Semitism, and analysis was considered a very left thing. We had all sorts of troubles. The other members of the Society all tried to accept things: "This is what it is and we have to live with it." I said: "Nonsense. Times are changing, we have to do something." So, first I got through the revision of our statutes-because of a government action at that time - then I got all sorts of things moving. I got some money, and gained permission-it had to be a special permission by the government to open a clinic. That was in 1930. We came back from Berlin in 1924, and in 1930 we had a clinic. (Swerdloff 1965, 390-91)

From the late 1930s, the political situation became more and more worrisome in Europe, and its influence directly affected the life of the Hungarian association too.

But then something happened. The Nazis occupied Germany, then Austria, and things became very, very sticky. For instance, every meeting of the Society and every seminar for the candidates had to be announced to the police, and they sent a plainclothes detective who sat in on all our meetings. ... "We know that a number of Communists come to this clinic." . . . I said: "Of course. They are neurotic people and they need

9 Otto Fenichel, reacting in a 1935 "Rundbrief" on a manuscript sent by Michael Bálint, criticizes him and the neo-Freudian analysts over 15 pages for placing culture beyond the instincts. He also reprehends Alice Bálint for her "one-sided culturalism."

${ }^{10}$ Collected posthumously in Bálint 1941. A complete compilation of her writings appeared in the French journal Le Coq-Héron in 1997 and 1998. 
treatment. And may I add something? As long as they come here you needn't be afraid of them." . . That happened in 1938, then came the occupation of Vienna, and I thought that it was time to go. I did not want to be caught up in it. I tried to make all sorts of contacts; I mobilized Jones and John Rickman, my two contact men. ... Eventually we got permission to come to England. (Swerdloff 1965, 393-94)

A 1938 letter from Alice in Budapest to her sister in Paris radiates an unrealistic optimism: "I always think that it would be better if at least you and Jutka ${ }^{11}$ came home. We tend to think that we won't be sucked into the vortex here. Think about it! Of course we are also hopeful in the meantime; it's hard to believe that we go with such open eyes towards such a horror. We are fantasizing that if this terrible situation would still be resolved, the whole population of Europe should be put on a ship and taken somewhere on holiday." ${ }^{\prime 2}$ (The image of the ship appears in her fantasy as a vehicle carrying people on holiday vs. the reality of transporting refugees.)

In 1939, the political situation forced the couple to emigrate from Hungary. They managed to find refuge in Manchester in January with the help of Ernest Jones, John Rickman, and probably Michael Polányi, who had already fled there from Berlin in 1933 (Mészáros 2005). The letters of Alice to her brother-in-law (László Dormándi) in Paris suggest that they started to settle down in their new circumstances, although they struggled with financial difficulties and war preparations infiltrated their everyday life.

The country is very much preparing here.... People have been told to always have food enough for one week and stuff like that. In the meantime, under the influence of the climate of English optimism, of course sometimes we completely forget about it all and settle for eternal peace. We are still satisfied with the English. We have a little money now, but it's not yet possible to live on that, just to rub along. Now we are committing ourselves to hospitality in the first place. Emmi [Mihály Bálint's sister] will be the first, then, I hope, Olgi, Juci, and my parents. ${ }^{13}$

11 Jutka was the nickname of Judit Dormándi (now Judith Dupont), a psychoanalyst living in Paris and the daughter of Olga Székely-Kovács.

12 Freud Museum Archives, London, Ferenczi bequest. (Emphasis in the original.)

13 Letter of Alice Bálint to László Dormándi, July 19, 1939. Freud Museum Archives, London, Ferenczi bequest. (Emphasis in the original.) 
Another letter also reported on their financial situation and the number of their analytical hours. She still hoped to be able to bring her mother to England. The last sentences indicate their common experiences regarding the loneliness and foreignness of emigrants.

The lack of money, in less romantic forms, is prevalent here too. Nevertheless it seems that we can get away without major loans or perhaps with no loans at all, which we find satisfactory. Unfortunately I have only one hour daily, Misi has four; from those, three pay. ... Currently I'm terribly excited about the visa for Mama.... I'm hounded by the nightmare that the outrage will break out before they can leave. What you write about your loneliness I can understand well. Although M. [Manchester] is not so big and strangers have a bigger respect than in Paris. ${ }^{14}$

Manchester became a sight of loss for the Bálints. On August 29, 1939, only a few months after their immigration and three days before the outbreak of World War II (and twenty-five days before Freud's death), Alice Bálint died from a ruptured aneurysm at the age of forty-one. The following year, her mother, Vilma Kovács, died in Budapest, and after the Nazi occupation of Hungary in 1944, Mihály Bálint's parents committed suicide. In 1945, Mihály Bálint moved to London where he joined the Tavistock Clinic in 1948. Alice had been elected to the British Society just before her death in July 1939.

Official obituaries highlighted Alice Bálint's ability to create and organize, her professional networking activities, and her charismatic personality among Central European (children's) analysts. "She was especially well-known and appreciated in the countries of Central Europe. The close contact of the Budapest group with those in Prague and Vienna would scarcely have been conceivable without her initiative and activity. She was one of the organizers of children's analysts between Vienna and Budapest" (Hoffer 1940, 102-103). "Her colleagues in the country of her adoption had begun to learn something of the charm and liveliness of her personality and had looked forward to a future in which she would make many valuable contributions to their common work" (Bálint 1940, 116).

14 Letter of Alice Bálint to László Dormándi, Aug. 11, 1939. Freud Museum Archives, London, Ferenczi bequest. 


\section{THE NOTEBOOKS}

Anna Freud proposed me to entrust her with the letters of Prof. [Freud] to the Doctor [Ferenczi] - under seal-in order to put them in a safe place in case of bombing. I thought of joining also the diaries of Alice, and those written in her maidenhood ... I took them out, fell into reading them and it was done of me. How much love, intelligence, kindness, desire to live, freshness, and I don't know what else there is in them. The whole world went down again, I relived the Tatras, the October Revolution, the Hungarian Commune, Alice's stay in Szeged, all the adventures of our love. How rich I was that all this belonged to me, she was entirely mine, she loved me with all her heart. After that I became very calm. ... I decided not to part with Alice's writings, there will certainly be difficult times when I will need their help. ${ }^{15}$

Alice Bálint's notebooks ${ }^{16}$ cover the years between 1917 and 1929; the ones from 1922, 1924, and 1928 are missing; she either did not keep a diary then or these were not maintained. These are especially rich and interesting documents in many respects, revealing her thoughts on herself and the events around her with remarkable maturity and sincerity, touching upon politics, love, femininity, the profession, and her future plans. The diary, for the most part, is rather abstract, in a way inductive, at least in the sense that it rarely reports on her daily activities for their own sake (sometimes evoking a sense of absence in the researcher and reader). It mostly deals with general questions regarding her personality; different philosophical, social, or political issues; occasionally issues with or about her family, especially her mother, Vilma Kovács, and later (in 1923) with Sándor Ferenczi. ${ }^{17}$ After the fall of 1918, she extensively recorded the evolution of her love for and relationship with Michael Bálint more through her reflections, comments, dilemmas, passion, and doubts than through "events" themselves.

There is the question of who the "implied reader" of this diary was. It is clear that she regularly showed it to Michael Bálint who also had a "checked"

${ }^{15}$ Letter of Michael Bálint to László Dormándi, June 5, 1940, in Dupont 2002a, 363.

16 The notebooks are held at the British Psychoanalytical Society Archives in London in the Bálint bequest.

17 For the reflections on her analysis with Ferenczi in the diary, see Borgos 2019. 
(booklet) that Alice could read ("check") in return. "I would like to write about a lot of other things, but it annoys me to know that you will read it. I decide in vain not to show you, I know I can't manage it; and still there are things I'm not sure if it's right, necessary, or nice to tell" (Jan 20, 1921). Being aware of this, one can presume a certain selection, idealization, control, and construction in the writing. At the same time, a certain level of a selection of this kind is inevitable even without showing it to anyone, by the very (reconstructive) process of narrating or remembering.

The most turbulent part of the diary is the period of 1918-1921, which is obviously connected to the current political events (the proclamation of the Hungarian Republic, then the short-lived Hungarian Soviet Republic, and the subsequent counterrevolution and "white terror"), which the author followed and commented on with a remarkable maturity. These years involved intense personal, social, and political changes and movements that concerned her as a young adult faced with emotional and career choices, a woman, a Jew, as well as a member of an upper middle-class family with socialist tendencies. The external events intertwined with her ideas and dilemmas regarding women's roles, her scientific interests, and her attachments to her most significant "object relation" at the time: her (future) husband, Mihály Bálint. I have selected some of the topics that dominated her discussions. In the following pages, I am going to present this period of the diary through an exploration of these prominent subjects.

\section{MEN AND WOMEN}

She returns to the issue of women 's and men's roles again and again, expressing somewhat contradictory ideas and desires. The age itself is contradictory and transitional in this sense, with diverse cultural representations of women and their roles. She continuously confronts these images through her own personality and in the new opportunities she gains during this pivotal period.

Her relationship to marriage, for example, is quite transparently expressed in a dream at the age of nineteen. "Tonight's dream: Olga and I married, I have a child too. ... I have dreamt of myself as a mother many times, and I have always detested the thought of having a husband. ... I would prefer a kid without a husband; I would raise him/her fine" (Nov. 24, 1917).

She very clearly expresses the belief that, for women, it is love that has long been assigned as the scope of all their desires, drawing them away from the public sphere and activities. "Women have not been citizens so far; all 
their desires and will have been stuck in one thing: love. ... These girls who go to university now can only go forward and never back" (Dec. 26, 1917).

At the same time, she vindicates a symbolically traditional role and value for women, attributing to them a down-to-earth, materialist, and generous approach to life, an innate "otherness," which was a typical viewpoint of the age as well. Yet she also connects "feminine" with "revolutionary," but primarily in an essentialist way, refraining from positioning the question into any kind of a feminist framework.

Minority rights, referendum, peace without annexation, this is a woman's voice.... I think of neither the feminist association, nor the peace league. . . . Women's partially respected, but often repressed feeling, which has always been considered as counter-political, has now been given a voice: the respect of sweet life and the respect for happiness. Our path cannot be immortality, but the ability and wish to live and love, in spite of our mortality. Mitten hindurch führt unser Weg (Ibsen). (Dec. 26, 1917)

I have come then to the old things: that woman always simultaneously represents the species and thus plurality is there in her basic being already. ${ }^{18}$. . The woman is sacrificing herself, the man is sacrificing everything for himself." (Apr. 15, 1919, post entry)

This image and sense of mission may have helped Alice Bálint reconcile the ultimate resistance against being a woman that she could not eliminate. "I didn't want this; I wanted to dress in pants while declaring that it is the greatest misery to be born a woman. I just trembled waiting for when my moustache would grow at last" (Dec. 28, 1917).

She evidently identifies science and culture as male domains; she finds a woman's value in her ability to inspire and motivate the man who, through his work, will struggle for her. "This is the nature of women, because if women were not precious, today there would be no science, art, literature, culture, all the wonderful male creations whose ancient roots are in the fact that men had to work for and please someone to achieve his goal" (Dec. 30,

18 These thoughts might remind us of women's images of plurality as represented by French postsructuralistst feminist psychoanalysts of the 1970s, especially Luce Irigaray. 
1918). This view, apparently due to her experiences and ambitions, later disappears from her notes.

\section{SOCIAL BACKGROUND AND IDENTITIES}

Alice Bálint had a complex web of inherited and chosen identities, and she related very consciously to her background and social circumstances. She strove to transgress the class boundaries determined by her family, partly out of political conviction and partly in order to challenge her own personal limits.

"It causes me a real pleasure to twit these bourgeois misses..." (Oct. 18, 1918). "And I will leave my piano, room, taste, beauty, and my nicely pleated velvet dress" (Jan. 13, 1919). "I have to try and see what I'm worth on my own ... and see whether it is true, what I thought of myself and the world here on Naphegy" (Mar. 1, 1919).

This attitude also appears in the context of her relationship, when she was planning for life after her marriage to Michael Bálint. "I want you to study; I don't need any luxuries, let's travel, dwell, and eat third class; I have a dowry, and perhaps you can earn some income so we can afford a simple student's life. True, everyone shakes their head at home and says I am too used to wealth. But I can settle for less" (Aug. 25, 1919).

Breaking away from her given, "ready-made" background and identities required a sense of strangeness and the displacement and relativization of all her commitments, although she also had a strong need for belonging too. The image of the "wandering Jew" that reappears in the entries represents this difficult state. ${ }^{19}$ "I am the paragon of the wandering Jew: as a Jew I'm Catholic; as a member of the bourgeoisie I'm a socialist; while I keep drifting towards politics, I'm a theoretician; and as a cosmopolitan, I long for a "homeland"' (Oct. 18, 1918).

After the fall of the Soviet Republic, the tensions between "Hungarian/ Jew" and "home/strangeness" were especially acute, and in this situation her status as a converted Jew posed a new dilemma. Both her Jewish and Hungarian identities were shifting constructions whose subjective meaning also took shape in this specific political context. "I have found that, especially in today's world, the most impossible thing is to be a converted Jew. Jews and

19 Alice Bálint converted to Roman Catholicism in 1916, at the beginning of her university studies. Mihály Bálint converted to Unitarianism in 1931. 
Christians are open enemies now, and by overcoming these things they are friends. But where is the place for chameleons like us? The only excuse I can make is that I longed to take roots somewhere else and now it turns out that I've lost even the shade of belonging" (Szeged, Mar. 3, 1920). She could not celebrate freely or laud the national army, independent Hungary, and Horthy. "If they knew me, they would silence the Jewish girl mockingly. I can't assimilate. I, who has never hesitated to consider myself Hungarian, now became homeless" (Szeged, Nov. 13, 1919).

Her social sensitivity and solidarity were also expressed during the Soviet Republic. "Here are we, for example, who consider ourselves rather admirable people who, in our large apartment, quietly tolerated poor students who came to Pest after 3-4 years of war to continue their studies, and had to discontinue their university training since there was no hole for them in which to huddle. And as long as there is no (proletarian) dictatorship, none of the lamented homeless will get an apartment" (Mar. 24, 1919).

\section{SCHOLARLY INTERESTS}

Alice Bálint contemplated on and made notes, typically on new scholarly fields like economics (which she considered as a potential occupation for a while), psychoanalysis, ethnology, and sociology. She mentioned a couple of authorsboth scholars and writers of fiction-in her entries about her reading list, displaying an impressively wide scope of interest. Socrates, Pascal, Schopenhauer, Simmel, Marx, Sombart, Fraser, Voltaire, Rousseau, Goncourt, Goethe, Stendhal, Ibsen, Shaw, Sand, Dostoyevsky, Dickens, Rilke, Novalis, Verlaine, Keats, Swinburne, Shelley, Flaubert, Anatole France, and the legend of Till Eulenspiegel (and the wandering Jew), among many others were mentioned.

According to a 1917 entry, psychoanalysis was already "passé" at that time, which suggests that she was somewhat familiar with it by then. "I declare to myself that I am back to my old form; no soul-searching, garbage dump, inner troubles, Jewishness, psychoanalysis, all have passed. Economics is my good friend, and I'm quite happy in its company. Slowly I have learned to read newspapers and I come to know what I want" (Nov. 2, 1917).

According to an entry two years later, she already understood what thrilled her about economics: "whether it exists at all" and "what is the relationship between economic phenomena and other social factors" (June 12, 1919). She disagreed with the mathematical school within economics "that seeks economic laws in the individual," but she liked the method itself. She 
mentioned the names of Gévous, Oppenheimer, and Simmel as necessary reading in this regard. She applied similes from the natural sciences for explaining political phenomena. "Conservatism in politics is like friction in nature. It makes progressive forces controllable" (Nov. 21, 1919).

The desire to become "someone" and to find a meaningful vocation is definitely an important thread throughout the diaries, though it does not follow one particular path for a while. Psychoanalysis, which became a growing field of interest for Alice Bálint from the 1920s on, represented a terrain where she could channel her personal needs and her intellectual ambitions (her "libido") in the most ideal way possible at that time; it was also a terrain to which she was clearly exposed through direct family influence. However, she maintained and used her interdisciplinary interests and erudition in her later work. The roots of this receptivity stemmed from the spiritual milieu of her childhood in the family home, the villa of her stepfather, architect Frigyes Kovács. Judith Dupont recalled, "The house of the Kovács was a kind of cultural centre. On Sundays, one could meet there the painter Róbert Berény, the music composer Leó Weiner, Grete Varró who directed a well known music school, some of her pupils, like Louis Kentner, as well as Sándor and Gizella Ferenczi and their family" (Dupont 2012, 70).

\section{PSYCHOANALYSIS, CHILDHOOD, AND FAMILY}

Starting in 1921, psychoanalysis appeared both as a subject of interest and a way of approaching and understanding herself and those around her in Bálint's entries. She was involved in serious self-analysis of her childhood and her relationship with her parents and siblings. It was no accident as this was the time when her mother began her psychoanalytic cure with Ferenczi, so "it's in the air," as she put it. She tried out Freudian premises and clearly became familiar with some of Freud's works.

You keep begging me to talk about myself, so now I will talk. Everything I do now will taste a bit like psychoanalysis, as it's always in the air since Mama has been in analytic treatment. This is why speaking is so difficult for me, because I see a lot of things now that I haven't seen before. ... Where is goodness e.g., if it turns out that it's nothing else than controlled jealousy? ... I find it extremely interesting how the whole psychic world of man is built from the most primitive elements. (Feb. 17, 1921) 
It was in front of her husband where she could rethink her own history, and her childhood hurt; in this relationship (and also in the written recording) she could rewrite herself. The roots of the traumas, the lack of love, self-confidence, and spontaneity, and the difficulty of revealing her emotions supposedly went back partly to times of separation and neglect during her childhood after her mother's divorce. At the same time, she expanded this feeling of being unloved and lonely to the later, warm family milieu as well. This sense of being "out of place" might also relate to her embarrassment in her new, more upscale bourgeois environment, which marked the otherwise positive turn of moving into the Kovács-villa. "I'm going to tell you my childhood as I see it now: since I can remember, I have always felt completely alone and unloved, which is all the more peculiar because I was definitely the favorite of the family" (Feb. 17, 1921).

The image of my life is becoming completely clear now; I began to see what has made me what I am, what has made me envious, weak, what takes my self-confidence away and what causes me to keep walking as a sinner in the world. . . All my childhood was spent feeling out of place where I fit, and my feeling towards men was composed of pride and envy. The external reason has long ceased, but ... the effect of the psychic fetters is still felt everywhere; if I loved, I could not say it; if I was happy, I could not show it; I could not cry; I could not dance; I could not please anyone. It was only in high school that I wrote a sentence down of my actual thoughts. What a feeling it was, I was drunk from that. (Mar. 25, 1921)

The missing (biological) father has a significant role in her childhood fantasies. "The actual content of my life was a tale, whose two protagonists were me and my imaginary father" (Feb. 17, 1921). The object of the following entry is probably also her biological father, Zsigmond Székely, who abandoned her and never sought contact with his children.

The other day I thought about my father again.... He's had nothing to do with anyone ever; when he is nice, he is posing, when he talks, he is sentimental, vain, pretentious, and lazy, absolutely phlegmatic, speaks little, never cheerful. He's smart, plays music, draws, but there is no energy in it, neither warmness nor fantasy-a petty bourgeois. A selfish, rigid, and vain man, ultimately. ... We don't understand him. I would 
like to meet him ... to ask what this strange, lonely, and actually sad man is like. (Aug. 12, 1919)

She observed people close to her (her step-father, mother) with a sharp eye, but also in a way that revealed her emotions.

Fricke [Frigyes Kovács] - I know him very well too. I watched him very carefully and I found much strangeness in him. He has a rare quality; he is a good man. My mother is the dearest woman. Smart, good, and understanding, she has a great capacity for love; she is very charming and very energetic. I know her very well too, and I see the traces that life has left on her.... I respect and love her; she is mine. Misi-I have already begun to understand him. But for me, his main feature is still the fact that I'm in love with him. (Aug. 12, 1919)

Her relationship with her mother was a powerful model and also a source of ambivalence, which was expressed with captivating openness. "I come to see the image of my life clearly, to see what took my self-confidence away and why I enter the world a sinner. I often feel that I somehow look at my mother from below, cowardly, very longingly, and also with hostility, and then I'd like to cry and I can't imagine that no one notices those things" (Mar. 25, 1921).

She also describes a complete and perfect analysis of a "mis-action" she made.

I was falling down the stairs; as I was lying on the ground I knew already that this is one of those accidents that are not accidents. Initially I tried to deny it, but when I told it to Mum and she asked why I fell, I suddenly got scared of the question, and thus it became evident that my guess was right. The issue was this: Mama is translating a book ${ }^{20}$ and it secretly hurt me that she showed it to Olga and Fricke and not to me.... While she was away, I read it and went up a floor for a pencil so that I could transcribe my potential notes, and this was when I fell down. I think I was punished for my resolution to find mistakes in the translation. (Mar. 25, 1921)

20 She must be referring to Freud's Jenseit des Lustprinzips (1920). It was translated by Vilma Kovács as A halálösztön és az életösztönök and published in 1923. 


\section{LOVE AND RELATIONSHIP}

Parallel to the "big revolution," the layers of her emotions and the history of her relationship with Michael Bálint are discussed throughout. They had a very open emotional life that seems to have been facilitated largely by Alice. Michael appears as more reserved, which often made her anxious. She apparently invested more in the relationship, at least in the initial period (although unfortunately we do not know which are Michael Bálint's notes). Feelings of doubt and anxieties alternate with euphoric and confessional notes. The desire for closeness was present together with the fear of losing herself or becoming too vulnerable and dependent.

Revolution and love at times get pressed together and intertwined. "The big revolution and my separate little revolution (both of which I identify with) made such a mess of me that I just feel dizzy about it" (Mar. 22, 1919). Eight months later she wrote: "Everything I see around me, the betrayed enthusiasm, the frightened hesitation, apathetic hopelessness, pointless efforts, the feeble will to act, inner and outer trouble and misery, I find in you, I find near you" (Szeged, Nov. 21, 1919).

The conflict between women's expected roles and her urge to actively shape the relationship and reveal her feelings led to frustrations involving two contradictory objectives and actions: "I want to be a woman by all means; on the other hand, I hate that you are the boy and I am the girl and I have to wait and ask.... On the one hand, I'm running from you as a girl from a boy, but on the other, I'm always trying to face you on the path although you started off so hard" (Jun. 7, 1921).

The most important feature of their relationship was its foundation of honest partnership and "companionship," with equal importance given to belonging and autonomy.

"I know well why I feel he is my mate. He is also a private-proud and a freedom-schmock, so we won't torture each other. ... Don't give up this pallove for anything; this is just what I need. (Jul. 5, 1919)."

Mutual support and normal life continues without the least formal bounds-these (very modern) values of partnership proved to be a stable base for the future.

We love each other, but the real question is: do we have to be spouses for that? My answer is yes, as long as it does not prevent you from learning and splashing. ... Formality is for the world; we should stay 
free with each other and be linked only by the things that can connect us according to genuine human needs: love and friendship. (Aug. 25, 1919)

She perceived, with a very modern and sharp eye, how the personal and the political are connected through the control and regulation of sexuality. These sentences also evoke the Freudian idea of the repression of instincts; but the recognition that this system of norms also includes politics that relate to the given society and gender is all her own, and it foreshadowed Foucault's view. "In love, especially in today's social circumstances, a little bit of politics definitely plays a role, since one has to keep demanding and violent desires under control. These are the politics about which I'm completely uncertain" (Jan. $1,1921)$.

After their marriage (in the summer of 1921), bodily intimacy became a more frequent issue in the diary. This was Alice Bálint's first relationship; she had not even kissed anyone. She had difficulties reconciling free sexuality and the role of a spouse. She wrote that it would have been easier if she was the mistress of an indifferent husband. She felt the culturally embedded resistance in her husband, which considered sensuality something shameful, especially in "decent" women. Apparently, however, they attempted to resolve these conflicts over social and gender expectations together with a rare openness.

"I'm afraid of you because I feel that you're afraid of me. Because I feel that deep in your heart you feel the degradation of love. You keep proving to yourself that love is not shame but happiness...." But in fact, they want the same (supposedly reinforced by their psychoanalytical readings and experiences too): "life, strong impulses, full experiences, love in its completeness emerging in our bodies without any sense of guilt and contemplation." (Jun. 7, 1921)

\section{POLITICS}

By the end of 1918, the entries follow and report on the current political events with remarkably mature comments and objectivity. The revolution, the period of the Soviet Republic and its fall, and the subsequent reprisals must have been a regular topic of conversation and concern in her family and circle of friends.

The declaration of the republic filled her with confidence and admiration for the meeting of idealism and reality. "Hungarian Republic. Wonderfully 
disciplined and intelligent laborers and a great, honest, and idealistic government that apparently completely breaks with the past. All the dreamers, admirers of utopias have now become serious people" (Nov. 2, 1918).

The proclamation of the Soviet Republic was an even greater promise and thrill. "Now, now, now the world is changing; so many new prospects open for suffering and confusion, but also for development and progress that it's a daze even to conceive. It is terrible and wonderful when new worlds are born" (Mar. 21, 1919). She tried to stay unbiased during the abuses and aggression too. "I can't get moved by the hatred of dictatorship when I saw a lamblike resignation about war. ... This is still not as bloody as the war, it's just more dangerous for us" (Jul. 11, 1919). And she accepted the fall of the republic with a similarly sober disillusion: "So the Soviet Republic has fallen. I can't cry with the communists and can't be happy with the capitalists... There will be confusion and all kinds of mess here for a long time. And my trust in people has been shaken a lot during these four months" (Aug. 2, 1919).

Her notes report on more and more aggressive impulses, open anti-Semitism, and physical attacks.

There was a pogrom in Budapest. It started at the university ... then it went on in the street. .. [W] hen they saw a suspicious-nosed person, they beat them up and finally turned them over to the Romanians as a communist. ... In public education too, the old officials started by beating up the new ones, i.e., the communists; so poor Sándor Radó too, then they rushed to Kármán, ${ }^{21}$ who said calmly: "Well, sir, please, I am Jewish too." So they were ashamed. . . Communist persecution is not very dangerous among the civilian population, although there are many refugees and persons hiding. (Aug. 11, 1919)

In an upsetting and expressive scene she captured the essence of the current state.

It happened last month. A group was standing under a placard that asked with big, red letters: "What to do with the Jews?" A Jewish man is coming, pale, weary, upper-class-looking; he stops by the placard and asks back very sadly, in a Jewish way: "What does it mean, what to do

${ }^{21}$ Tódor (Theodor von) Kármán (1881-1963) was a physicist and mathematician. During the Soviet Republic, he worked as a deputy people's commissar for public education. 
with the Jews? What to do with the Christians, what to do with people?" His voice was very desperate; no one said a single word. (Szeged, Nov. $13,1919)$

The political situation directly influenced her own life too, but her reflections touched upon general questions about the position of her culture and the toleration of "strangeness," that is to say "critical intellectuals" in society.

A pogrom is going on at the university. You fire many good people now, but you will regret it later. My heart hurts very much. I liked and wanted to be there. I wanted to work there, to make the Hungarian republic. ... And now I still have to leave. . . . Pest culture was rootless anyway. ... It's not professors that are needed here but overproduction. There is no need for us. We are needed where culmination is going on already, there they can bear strangers as they don't have to worry about the basic tone anymore. (Aug. 19, 1919)

Her friends provided life-long, stable refuge even in the most difficult circumstances. "Whatever good may happen to me, this circle of friends will always be one of the most beautiful things I received from life. What happens out there though, it's so terrible that I can only think of it with despair. . . People are overtaken by a denunciation fit" (Szeged, Jan. 2, 1920).

The numerus clausus law, which came into force in September 1920, was not mentioned in the diary, although its influence could be felt somewhat later (and Mihály Bálint had finished medical university by that time). Likewise, the specific motives and antecedents for their departure to Berlin in 1921 were not detailed in the diary, but apart from professional training and the adventure of itself, there were strong political motives as well. It seems that they did not travel together; her husband left first, and Alice followed him after some time. Her diaries report on this intermediate period, expressing ambivalence to travel primarily from a private and emotional perspective, with an emphasis on and magnification of their temporary separation. "For some time I've been thrilled by the thought that you are off to Berolina soon. I'm glad and I'm frightened. . . . I'd like to shorten this transitional period somehow. I have imagined how I will travel to you many times, and this will be the longest and the shortest travel of my life" (Feb. 15, 1921). 


\section{Conclusions}

Can we find any traces of Alice Bálint's later mode of thinking or her theoretical attachments in the diary entries? Very indirectly. Her social sensitivity, sense of reality and criticism, autonomy, and attachment are traits on which she unquestionably relied all along. Her collaboration with Michael Bálint was rooted in and founded on an emotionally rich relationship, and they consciously maintained a strong partnership, sharing their thoughts on themselves and the world. This is confirmed by the words of Michael Bálint in the introduction of his book entitled Primary Love and Psychoanalytic Technique, in which he emphasized that all of his scholarship before 1939 had emerged from their joint work.

Starting with our shared enthusiasm for Totem and Taboo till her death in 1939, Alice and I read, studied, lived, and worked together. All our ideas ... were enjoyed and then tested, probed, and criticized in our endless discussions. Quite often it was just chance that decided which of us should publish a particular idea. Apart from psychoanalysis, Alice's main interests were anthropology and education, mine biology and medicine, and usually this factor decided who should write about the idea. We published only one paper jointly, although almost all of them could have been printed under our joint names. (Bálint 1952)

Alice Bálint's notebooks may serve as a rich primary resource for reconstructing her personal and professional development and tracing the history of her most significant relationships. More generally, they provide valuable insight into the social and political worlds of early twentieth-century Hungary and the opportunities and limits for a middle-class, Jewish woman with intellectual ambitions.

\section{REFERENCES}

Appignanesi, Lisa, and John Forrester. 2000. Freud's Women. London: Penguin Books. Bálint, Alice. 1931. A gyermekszoba pszichológiája [The psychoanalysis of the nursery]. Budapest: Pantheon. 
1941. Anya és gyermek [Mother and child]. Budapest: Pantheon.

Bálint, Michael. 1940. "Alice Bálint." The International Journal of Psycho-Analysis 21: 116. — 1952. Primary Love and Psychoanalytic Technique. London: Hogarth Press.

Borgos, Anna. 2017. "Women in the History of Hungarian Psychoanalysis." European Yearbook of the History of Psychology 3: 155-80.

_. 2019. "Alice Bálint and her diaries: '... This little fixation seems to remain..." Psychoanalysis and History 21, no. 1: 23-52.

— 2018. Holnaplányok. Nök a pszichoanalízis budapesti iskolájában [Girls of tomorrow: Women in the Budapest School of psychoanalysis]. Budapest: Noran Libro.

Chodorow, Nancy. 1989. "Seventies Questions for Thirties Women: Gender and Generation in a Study of Early Women Psychoanalysts." In Feminism and Psychoanalytic Theory, 199-218. New Haven: Yale University Press.

Danto, Elizabeth A. 2005. Freud's Free Clinics: Psychoanalysis and Social Justice, 19181938. New York: Columbia University Press.

Dupont, Judith. 1993. "A Kovács-Bálint dinasztia” [The Kovács-Bálint dynasty]. In Fortunatus öröksége [The heritage of Fortunatus], 7-12. Budapest: Párbeszéd Könyvek.

- 2002a. "Excerpts of the Correspondence of Michael and Alice Balint with Olga, Ladislas, and Judith Dormandi." The American Journal of Psychoanalysis 62, no. 4: 359-381.

_. 2002b. "L’exil avant l'exil. Michael et Alice Bálint." Topique 80, no. 3: 95-101.

_ . 2012. "Alice Bálint, a Short but Productive Life." In Ferenczi for Our Time, edited by Judit Szekacs-Weisz and Tom Keve, 69-75. London: Karnac.

—. 2015. Au fil du temps... Un itinéraire analytique. Paris: Campagne/Première.

Felski, Rita. 1995. The Gender of Modernity. Cambridge, MA: Harvard University Press.

Ferenczi, Sándor. 1906. "Szexuális átmeneti fokozatokról" [On transitional stages of sexuality]. Gyógyászat 46, no. 19 (1906): 310-14.

_ 1908. "Az ejaculatio praecox jelentőségéről" [On the significance of ejaculatio praecox]. Budapesti Orvosi Újság, 4. Freidenreich, Harriet P. 2002. Female, Jewish, and Educated: The Lives of Central European University Women. Bloomington: Indiana University Press.

Gilman, Sander. 1991. The Jew's Body. London and New York: Routledge.

Harmat, Pál. 1994. Freud, Ferenczi és a magyarországi pszichoanalízis [Freud, Ferenczi, and the Hungarian psychoanalysis]. Budapest: Bethlen Gábor Könyvkiadó.

Haynal, André. 1988. The Technique at Issue: Controversies in Psychoanalysis from Freud and Ferenczi to Michael Balint. London: Karnac.

Hermann, Imre. 1982. “Souvenirs de Michael Balint (1896-1971)." Le Coq-Héron 85: 45-49.

Hoffer, Willi. 1940. “Alice Bálint.” Internationale Zeitschrift für Psychoanalyse und Imago 25, no. 1: 102-103.

Karady, Victor. 2004. The Jews of Europe in the Modern Era: A Socio-historical Outline. Budapest and New York: CEU Press.

Kovács, Vilma. 1936. “Training and Control-analysis." International Journal of Psychoanalysis $17: 346-54$.

Mészáros, Judit. 2008. “Az Önök Bizottsága.” Ferenczi Sándor, a budapesti iskola és a pszichoanalitikus emigráció ["Your Committee": Sándor Ferenczi, the Budapest School, and psychoanalytic emigration]. Budapest: Akadémiai Kiadó. 
- 2014. Ferenczi and Beyond: Exile of the Budapest School and Solidarity in the Psychoanalytic Movement During the Nazi Years. London: Karnac.

Moi, Toril. 1990. "Patriarchal Thought and the Drive for Knowledge." In Between Feminism and Psychoanalysis, edited by Theresa Brennan, 189-205. London and New York: Routledge.

Mühlleitner, Elke. 2000. "Frauen in der Psychoanalytischen Bewegung." Psyche 54, no. 7: 642-58.

Roith, Esther. 1988. "Freud's Women Disciples." In The Riddle of Freud: Jewish Influences on His Theory of Female Sexuality, 27-46. London and New York: Routledge.

Roudinesco, Élisabeth. 2000. "Les premières femmes psychanalystes." Topique 71: 45-56.

Swerdloff, Bluma. 2002. "An Interview with Michael Balint [1965]." The American Journal of Psychoanalysis 62, no. 4: 383-413.

Thompson, Nelly L. 1987. "Early Women Psychoanalysts." International Review of Psycho-Analysis 14: 391-406.

Vogelsänger, Peter. 2010. “Alice und Michael Bálint in Berlin (1921-1924).” LuziferAmor 23, no. 45: 169-78.

Zaretsky, Eli. 2005. Secrets of the Soul: A Social and Cultural History of Psychoanalysis. New York: Vintage Books. 

PART TWO

Ferenczi and Róheim Revisited 



\section{Violence, Trauma, and Hypocrisy}

Ferenc Erös

Violence is one of the central themes in Ferenczi's work. Violence can be interpersonal, familial, therapeutic, and social-Ferenczi treats these different aspects simultaneously since he considers them as inseparable from each other, with regard to their structure as well as their traumatogenetic function. Violence is not a single act but a series of events, which includes its antecedents as well as its consequences. One consequence of a violent act may be the complete annulment or concealment of the act itself. As Ferenczi describes this process in his emblematic article "Confusion of Tongues between the Adults and the Child":

When the child recovers from such an attack [the trauma], he feels enormously confused, in fact, split-innocent and culpable at the same time-and his confidence in the testimony in his own senses is broken. Moreover, the harsh behaviour of the adult partner tormented and made angry by his remorse renders the child still more conscious of his own guilt and still more ashamed. Almost always the perpetrator behaves as though nothing had happened, and consoles himself with the thought: "Oh it is only a child, he does not know anything, he will

A shorter version of this paper was published under the title "Against Violence: Ferenczi and Liberal Socialism" (Erös 2018). 
forget it all." Not infrequently after such events, the seducer becomes over-moralistic or religious, and endeavours to save the soul of he child by severity. (Ferenczi [1933] 1999, 299)

In the same article Ferenczi also speaks about a "hypocrisy hitherto regarded as impossible," that is, professional hypocrisy (Ferenczi [1933] 1999, 295). Professional hypocrisy is a main concern for Ferenczi in the Clinical Diary, too. For example, he writes, "Patients feel the hypocritical element in the analyst's behaviour" (Ferenczi [1932] 1988, 200), or "Hatred of patients is behind the hypocritical friendliness of the doctor toward the patients" (201). He recognizes a similar hypocrisy, an endeavor "to save the soul of the child by severity," on the part of the educators, teachers, and parents as well, who are "pregnant with rage that is disguised in benevolent behaviour" (167). In the Diary, Ferenczi regards benevolence, or "excessive goodness," as a manifestation of the overcompensated sadism of obsessional neurotics.

The negativity of "goodness," "fairness," or "benevolence," which are masks concealing a trauma, was also a topic for Erich Fromm, who, in his essay on "The Social Determinants of Psychoanalytic Therapy" speaks about the apparent tolerance of the therapist, which is, in fact, the concealment of "doctors' hidden sadism" (Fromm [1935] 2000, 160-61). As Lacan put it even more provocatively in his essay on "the mirror stage": "we can find no promise in altruistic feeling, we who lay bare the aggressiveness that underlies the activity of the philanthropist, the idealist, the pedagogue, and even the reformer" (Lacan 2006, 80-81). Concerning "goodness" as an ethicophilosophical category, I am referencing György Lukács, who, in his 1911 dialogical essay "On Poverty of Spirit," points to Prince Mishkin, the hero of Dostoyevsky's Idiot whose "goodness" is unproductive, confusing, and unintentionally sows tragedy (Lukács 1911).

But let us go back to Ferenczi. On a more general level, for him, society as a whole "under the prevalent regime" is hypocritical. The benevolent surface or skin barely conceals what he calls in the Clinical Diary, "the terrorism of suffering," of which we are all victims because of repressive and authoritarian child rearing practices and "the passionate behaviour of adults" (Ferenczi [1932] 1988, 200). The consequence of these is mysticism, religiosity, defense against sexual impulses, authoritarianism, as Fromm and Wilhelm Reich demonstrated in the very same epoch in which Ferenczi lived.

It is tempting to simply use Ferenczi's growing alienation from and his traumatic breach with Freud in the late twenties as the explanation for his 
passionate rage against hypocrisy. However, the critique of social and educational hypocrisy was one of his main concerns from the very beginning of his psychoanalytic career in 1908. Hypocrisy, in Hungarian, "képmutatás," literally "showing an image," may have been an everyday experience for the citizens of the Austro-Hungarian Monarchy. The hypocrisy of the life-world of the Monarchy was perhaps best characterized by the Austrian writer Robert Musil in his most significant novel The Man without Qualities:

[This country] by its constitution ... was liberal, but its system of government was clerical. The system of government was clerical, but the general attitude to life was liberal. Before the law all citizens were equal, but not everyone, of course, was a citizen. There was a parliament, which made such vigorous use of its liberty that it was usually kept shut; but there was an emergency powers act by means it was possible to manage without parliament. (Musil [1930] 1979, 33)

Ferenczi focused on the human side of this hypocriticalness. As he wrote in his first psychoanalytical contribution, the paper he gave at the First International Congress of Psychoanalysis in Salzburg entitled "Psychoanalysis and Education": "Only when the hypocritical mysteriousness in sexual matters has ceased to exist, when everyone will know of the processes of his own body and mind-i.e., only with conscious cathexis-will sexual emotions be truly mastered and sublimated" (Ferenczi [1908] 1994, 285-86). In his letter to Freud on February 5, 1910, he affirmed: "Once society has gone beyond the infantile, then hitherto completely unimagined possibilities for social and political life are opened up. Just think what it would mean if one can tell everyone the truth, one's father, teacher, neighbour, and even the king. All fabricated, imposed authority will go to the devil" (Freud and Ferenczi 1908-1914, 130).

The key concepts of these earlier works are the notions of "unnecessary compulsion" and "excessive repression." Repression in contemporary society, Ferenczi argues, demands not only a minimum of instinctual renunciation that the already sufficiently demanding external circumstances requires, but also the subjugation of its members, the deprivation of their freedom, human dignity, and autonomy. "Excessive repression," speculates Ferenczi, sets free those instinctual forces that lead to religious superstition, the cult of authority, and a rigid adherence to obsolete social forms. In "Psychoanalysis and Education" he argues: 
Liberation from unnecessary inner compulsion would be the first revolution to bring real relief to mankind, for political revolutions have achieved only that the external powers, that is, the means of coercion, have changed hands, or that the number of the oppressed has risen or fallen. Only people liberated in this real sense will be able to bring about a radical change in education and prevent permanently the return of similar undesirable circumstances. (Ferenczi [1908] 1994, 283)

Ferenczi as a social critic maintained a strong link to progressivist and intellectual movements of his age like the Galileo Circle and other groupings of young scholars and students in Budapest during the fin-de-siècle and pre-war periods; these were groups whose members were devoted to the most various innovative, exciting ideas, reforms, and revolutionary dreams. ${ }^{1}$ Ferenczi as a "reform-utopian" envisioned a future society in which natural urges and desires would be treated not with negation and repression, but with a "sound government" that would replace hypocrisy and the blind adoration of dogma and authority (Ferenczi 1911). In an article on "Psychoanalysis and Its Judicial and Sociological Relevance," he affirms that "between anarchy and communism . . ., between unrestrained individual license and social asceticism, there must be somewhere a reasonable individual-socialistic just milieu that cares also for individual welfare as well as for the interests of society, that cultivates the sublimation instead of the repression of instincts, thereby preparing a quiet path for progress assured from revolutions and reactions" (Ferenczi [1913a] 1994, 433).

Ferenczi's focus was, however, not only on society as such, but on the process of its reproduction, the child, the infantile on both the onto- and phylogenetic levels. His fundamental essay "Stages in the Development of the Sense of Reality" ([1913b] 1999) describes the structural trauma of the individual and the collective, the trauma of birth, the "same cruel game repeated with every new stage of development" (80), the violent renunciation of omnipotence, the splitting of the ego through projection and introjection. In this work, Ferenczi already linked "the great step in our individual repression, the latency period" with "the last and greatest that befell our ancestors . . . with the misery of the ice age, which we still faithfully recapitulate in our indi-

1 See also Erős (2012b). 
vidual life" (80). This very Lamarckian idea was further elaborated on during World War I (as his correspondence with Freud shows) and then in his work Catastrophes in the History of Sexuality, also known as Thalassa, published in 1924 (Ferenczi [1924] 2005). It was the Great War that first initiated Ferenczi into the reality of massive social and collective violence, where each participant has their own history of personal trauma. In an article published in 1915 under the title "The Ice-Age of Catastrophes" he wrote:

The worst and most upsetting events could appear as unbridled experiences of experimental psychology, a kind of "Naturexperiment" that the scientist cannot realize in his study, but at most, within the laboratory of his mind. War is one of those laboratory experiments taken to a cosmic level. In peacetime, only through the complex examination of dreams, of neurotic symptoms, of artistic creations, of diverse religions can one demonstrate ... that the human psyche presents multiple layers, the culture is but a prettily decorated shop-window whilst at the back of the store the more primitive merchandise is piled up. War had brutally wrested of this mask and has shown us man in his deepest, truest nature at the heart of man, the child, the savage, the primitive.... It is in this way that the catastrophes of the ice-age have forged longago in the first familial and religious society, the basis of all subsequent evolution. War has simply thrown us back into the ice-age, or rather, it has unveiled the deep imprints that is had left in the psychic universe of humanity. (Ferenczi [1915] 1999, 125)

The personal impact of the "ice age of catastrophes" arrived on Ferenczi's doorstep shortly after the outbreak of the war, in October 1914, when he was ordered to join as a "volunteer" physician for the 7th Royal Hussar Regiment stationed in Pápa, a small garrison town in Western Hungary. In early 1916 he was ordered to return to Budapest, where he was in charge of a section for nervous diseases in "Mária Valéria" barrack hospital. As we know from his letters, he had been writing to Freud at the same time he started working with cases of traumatic neuroses. These cases might be one of the sources for what he wrote about later in Clinical Diary: "What is traumatic, is the unforeseen, the unfathomable, the incalculable. If I kill myself, I know what will happen. Suicide is less traumatic (not unforeseen)" (Ferenczi [1932] 1988, 171).

In his article "Two Types of War Neuroses" ([1916] 1999), Ferenczi discusses his psychoanalytic conception of the genesis of traumatic neuroses, 
based upon Freud's concept of hysteria, for the first time in detail. According to him, the shell-shocked patients' symptoms (tremors of the feet or full body musculature, gait disorders, spastic paresis, cramps, hyperaesthesia, etc.) had all been caused by psychic trauma and not by central lesions of the nervous system as was widely believed by many contemporary neurologists. Observing patients suffering from astasia (inability to stand) and abasia (inability to walk), Ferenczi thought that these patients:

... had repressed into their unconscious the affective reaction to certain psychic traumata, for the most part experiences that were adapted to diminish their self-confidence, repressed in the unconscious from where they continued to influence their activities, and any threat of repetition of the pathogenic experience led to a development of anxiety. The patient then learns to escape anxiety states by avoiding any activity that would in any way lead to the repetition of the pathogenic situation. (hysterical anxiety). (Ferenczi [1916] 1999, 137-38)

Coordination disturbances like tremors "[become] a defence formation that will protect the patient from re-experiencing the alarm" (Ferenczi [1916] 1999, 141). In other cases, like hyperaesthesia (hypersensitivity of all the senses), "the psyche does not wait for an external stimulus in order to react it exaggeratedly, but creates for itself the image at which it can then become alarmed. The unpleasant symptom too, therefore, is in the service of the effort of self-healing. (Traumatophilia)" (Ferenczi [1916] 1999, 143).

According to Ferenczi, the psychoanalytic observation of shell-shocked patients proves Freud's original hypothesis about the predominantly sexual aetiology of hysteria, inasmuch as many patients behave as if they are victims of childhood sexual assault. The result of psychic shocks, argues Ferenczi, may be a neurotic regression, that is, "a return to a stage of development long outgrown both onto- and phylogenetically" (Ferenczi [1916] 1999, 40). At the end of his article, Ferenczi refers to "the result achieved by many neurologists from treating war neuroses by painful electric stimuli" that may be due "to the fact these painful sensations satisfy the patient's latent traumatophilia" (Ferenczi [1916] 1999, 144).

Space does not allow for me to go into details about treatment with electric stimuli. It is enough to say that electroshock therapy was in fact a disguised form of bodily torture in order to elicit obedience and to discipline and punish (in a Foucauldian sense) soldiers who protested against the horrors 
of war by producing psychic symptoms. Electroshock therapy was called also the "surprise cure," assuming that the great and sudden pain caused by the shock would make the patient "forget" his symptoms forever. War neurotics had been stigmatized with malingering, feminine and infantile features, moral inferiority, cowardice, lack of will and patriotism. It was supposed and feared that this kind of "male hysteria" may also infect "healthy" soldiers, destroying their will, determination, patriotism, and heroism. Therefore, hysterics should be healed using the harshest methods, and isolating incurable degenerates, schizophrenics, and mentally handicapped persons from the rest of their compatriots. The famous German psychiatrist Emil Kraepelin (who described first the symptoms of schizophrenia as "dementia praecox") declared that the defeat of Germany was caused not primarily by the armies of the enemy, but by "psychopathic revolutionaries" who spread mass hysteria and pacifism among the population. Psychiatry and psychopathology had become an important part of the war propaganda machine, too, stigmatizing the inner and outer enemies with pathological character traits (femininity, aggression, etc.). For example, some German psychiatrists used the strange diagnostic term "psychopathia gallica" to signify the alleged "femininity" of the national character of the French enemy. ${ }^{2}$

In Hungary, a military physician named Dr. Viktor Gonda was one of the most well known practitioners of electrotherapy. His methods and activities were noticed by the military-medical authorities throughout the Monarchy and also by the wider public. Ferenczi, as we know from his correspondence with Freud, had become acquainted with him in 1917 at a military psychiatric ward in Budapest. On October 10, 1917, he reported to Freud: "[Dr. Gonda] is spreading himself around more and more here, is having column-length articles written about his miracle cures (in daily newspapers), and all the naive folk, from archduke to university professor on down, are coming to our hospital to observe the miracle together" (Freud and Ferenczi 1996, 243). In another letter to Freud on December 13 he called Gonda a "half-crazy half-swindler." He went on, "No matter how skillfully he carries out his suggestion cures, his ignorance and his megalomania were becoming well-nigh unbearable to me" (ibid.) I do not know if Gonda was really a swindler or if he truly believed that electrotherapy could genuinely alleviate the symptoms of shell shock, not so much with the physical impact of the

${ }^{2}$ On the treatment of war neurotics during World War I, see Erős 2010, 2017. 
shocks, but with his own suggestive power. But it was, in any case, hypocrisy, or "showing an image." In fact, images of treatment appear to be a theatrical performance that may bring to mind Charcot's "theatre of hysteria."

But the séance continued. Immediately before the end of the war, on September 28-29, 1918, the Fifth International Congress of Psychoanalysis took place in Budapest. The congress, dominated by the discussion of war neurosis, was only nominally "international" since most participants came from Austria-Hungary and Germany, that is, powers on the brink of their final defeat. Paradoxically, however, the congress was a grand victory for Ferenczi, who succeeded in persuading military health authorities to represent themselves at the congress. Far beyond its professional significance, the Budapest congress became a celebrated public event mainly due to $\mathrm{Fe}$ renczi's determined efforts and his strong connections to the Budapest intellectual elite; it was a "performance" for the capital and the opening session boasted several notable attendees. The congress seemed to reconfirm Freud's earlier vision of Budapest as "the headquarters of our movement" (Freud and Abraham 2002, 382). Moreover, in an order issued a few days after the congress by the Austro-Hungarian Ministry of War, military health authorities accepted, in principle, the idea that psychoanalysis may be attempted as a final treatment method in such cases of traumatic neuroses where patients had already shown resistance to other methods. ${ }^{3}$ It was, of course, a Pyrrhic victory, since the war was not only lost but the Dual Monarchy disintegrated within a few weeks. In October, revolutions broke out in both Vienna and Budapest.

In the turbulent autumn of 1918, hundreds of medical students petitioned the new democratic government by Count Mihály Károlyi to invite Ferenczi to teach psychoanalysis at the University of Budapest. The university, however, resisted, and Ferenczi's university assignment only became a reality months later, by the government of the Hungarian Soviet Republic, led by Béla Kun, which came to power on April 1, 1919. Ferenczi accepted a professorship as compensation for the earlier neglect of the communist regime, which he was far from enthusiastically supporting. Although he somewhat sympathized with the plans of the government regarding the reform of public health and medical education, he felt threatened by the plans of the regime

\footnotetext{
${ }^{3}$ For more on the history of the congress and its aftermath, see Erös and Giampieri 1987; Erös 2010 and 2012a.
} 
to nationalize the whole health system and to deprive doctors of their private praxis as the basis of their (including Ferenczi's) existence. ${ }^{4}$

After the defeat of the first Hungarian communist regime on August 1, 1919, Ferenczi was among those professors who were immediately dismissed from their positions. A year later he was also barred from the Budapest Royal Medical Association. The whole situation is best characterized in his letter to Freud on August 28, 1919:

After the unbearable "Red terror," which lay heavily on one's spirit like a nightmare, we now have the White one. For a short time it seemed as if they would succeed in moderating the parties toward a just compromise, but in the end the ruthless clerical-anti-Semitic spirit seems to have eked out a victory. If everything does not deceive, we Hungarian Jews are now facing a period of brutal persecution of Jews. They will, I think, have cured us in a very short time of the illusion with which we were brought up, namely, that we are "Hungarians of Jewish faith." I picture Hungarian anti-Semitism-commensurate with the national character-to be more brutal than the petty-hateful type of the Austrians. It will very soon become evident how one can live and work here. It is naturally the best thing for Ya. To continue working in complete withdrawal and without a sound. Personally, one will have to take this trauma as an occasion to abandon certain prejudices brought along from the nursery and to come to terms with the bitter truth of being, as a Jew, really without a country. (Freud and Ferenczi 1996, 365)

After the traumata of the failure of both revolutions and in the atmosphere of severe repressions, Ferenczi felt himself in a vacuum both politically and professionally. In these circumstances, he became acquainted with a young man, Aurél Kolnai (1900-1973), who later became known primarily as a political scientist and a conservative moral and philosopher in the West. Kolnai studied social sciences in Budapest and Vienna, was a member of the Galileo Circle, and was, for a short time, intellectually committed to psychoanalysis, although he became an ardent critic a few years later. ${ }^{5}$ In early 1920, he joined the Hungarian Psychoanalytic Society and gave there a lecture under the title "Psy-

${ }^{4}$ See more details in Erős 2012a, 2019 and Erős and Giampieri 1987.
${ }^{5}$ See also Kolnai's autobiography (1999). 
choanalysis and Sociology." It was also the title of the book Kolnai published the same year in Vienna at the International Psychoanalytic Publishing House (Kolnai [1920] 2013). This work was basically a pamphlet against Russian Bolshevism, written in connection with the failed revolutionary movements in Central Europe. Kolnai saw revolution as a mass psychological phenomenon, the manifestation of an oedipal revolt of the tribal brothers against the domination of the father that only leads to the even more repressive domination of tyrannical leaders or "substitute fathers." Kolnai's arguments could have provided inspiration for Sigmund Freud, whose major work on mass psychology was published a year later (Freud 1921). Kolnai's book also played an important role in Marxist debates on psychoanalysis in the twenties, since it became a scapegoat, "an ideological phantom," a favorite example of how Freudianism was a particularly dangerous branch of bourgeois ideology.

Kolnai was particularly critical of what he called "anarcho-communism," and he advocated "liberal socialism" as an antidote for anarchistic degenerations. There are two brief, recently published manuscripts of Ferenczi entitled "Parallels between Marxism, Communism, and Anarchism" and "Parallels between Psychoanalysis and Liberal Socialism." Both manuscripts belong to the Ferenczi estate, which was donated to the London Freud Museum by Dr. Judith Dupont a few years ago. These texts reflect Kolnai's views. ${ }^{6}$

In Manuscript I, Ferenczi raises the issue of parallels between psychoanalysis and the Marxist concept of history. He comes to the conclusion that this parallel is unsatisfactory since the goals of the two schools are basically different. He associates Marxism with "rigid dialectics" and rejects its alleged economic determinism as well as the concept of "class struggle," instead arguing that for psychoanalysis, the homo infans rather than the homo oeconomicus is the basic structure. He contrasts the Darwinian "selectionism" attributed to Marxism with Lamarckian evolutionism. In fact, Ferenczi's critique is directed not only against Marxism, but also against a so-called "psychoanalytic mentality" that "is almost equivalent with an anarcho-communist mentality," which dreams of the elimination of all repressions, the satisfaction of all desires, and envisages a "fatherless society" as the ultimate goal of psychoanalysis. Ferenczi contrasts this kind of "wild" mentality with "the healthy stock" of psychoanalysis, the aim of which is not the "liberation of instincts," but rather "an instrument for the self-liberation of personality." Finally, Fe-

\footnotetext{
${ }^{6}$ See more details and the full text of the manuscripts in Erös 2014.
} 
renczi acknowledges that "a certain historical innovative role, an experiment for a new, more deeply penetrating, more scientific approach to things" is common in both movements. However, "psychoanalysis rather joins Durkheim and not the Marxist sociology and politics, and, in concrete and actual questions joins liberal socialism."

In Manuscript II, Ferenczi further elaborates his ideas on a possible parallel between psychoanalysis and liberal socialism. He argues that while the parallel with Marxism failed, "psychoanalysis and liberal socialism share the same worldview, the same ethical sense, and the same task in the service of the welfare of men." Psychoanalysis, as he argues, cannot bring "salvation," but only works "on the self-salvation of the individual." Discussing some basic themes of liberal socialism, Ferenczi points out the discovery of the significance of land, attributing the main responsibility for all social diseases to two conditions. The first is an "antirational, rigid fixation to the land, which resists industrialism," and the second is "the treatment of land as a simple commodity." As for the fixation on land, Ferenczi finds a psychoanalytic parallel for it in "land eroticism," and in "an incestuous fixation to the mother, which inhibits free consciousness and support the primary despotism of the father." On the other hand, argues Ferenczi, "the treatment of land as a simple commodity would be equivalent with a helpless repression, which is incapable of higher developments."

The idea of liberal or individual socialism reappeared in an article entitled "Psychoanalysis and Social Politics" (Ferenczi [1922] 1999). In this article, he expresses his hopes that "time will allow for the development of an 'individual-socialist' orientation which would take into account the natural differences between individuals, of their aspiration to independence and happiness, whilst acknowledging the need for communal life, and the restrictions, at times difficult to bear, which it imposes" (Ferenczi [1922] 1999, 211). In the article he also explains his motives for accepting a professorial position during the communist government in 1919, affirming "psychoanalysis has refused to perceive any political party, be it individualistic or collectivistic, as the representative of true human nature" (212).

In the 1920s, Ferenczi seemed to sink into the "thalassic regression," that is the prehistoric catastrophes preceding the ice age of phylogenetic and ontogenetic traumata. There is no space here to unpack my idea that Ferenczi's Thalassa can be re-interpreted as a political philosophy of catastrophes. I can only refer here to the book of the French philosopher Catherine Malabou's Ontology of the Accident, where she claims, "the history of being itself con- 
sists perhaps of nothing but a series of accidents which, in every era and without hope of return, dangerously disfigure the meaning of essence" (Malabou 2009, 91).

Shortly before his death, Ferenczi returned to his earlier ideas on "individual collectivism" in the Clinical Diary. Even if there is no salvation for the individual faced with trauma, terror, and death, Ferenczi foresees improvements and progress for humanity based on a "successful interaction of egoistic and universal tendencies" (Ferenczi [1932] 1998, 18). In another place in the Diary he writes:

If one were not ashamed to indulge in prophecies, then one would expect from the future neither the triumph of one-sided ruthless capitalism nor that of fanciful egalitarianism, but rather a full recognition of the existence of purely selfish drives, which remain under control but must be partly satisfied in reality; the elimination of a great deal of neurotic, still passionate, one might even say violently excessive goodness (eat-bird-or-die policy), and, finally, perhaps the gradual unfolding of a naïve good-heartedness. (Ferenczi [1932] 1998, 152)

This was, of course, a naïve and utopian idea that appeared in the shadow of Stalinism and the menacing victory of Nazism in Germany in 1933, the year of Ferenczi's death. ${ }^{7}$ It might also be regarded as the anticipation of the social policy of the modern welfare state, which attempts to balance "ruthless capitalism" and "fanciful egalitarianism."

\section{REFERENCES}

Berman, Emanuel. 2003. "Ferenczi, Rescue and Utopia." American Imago 60, no. 4: 429-44.

Erős, Ferenc. 2010. "Gender, Hysteria and War Neurosis." In Gender and Modernity in Central Europe: The Austro-Hungarian Legacy, edited by Agatha Schwartz, 185201. Ottawa: University of Ottawa Press.

7 On Ferenczi's utopianism, see Berman 2003. 
2012a. "Psychoanalysis behind Iron Curtains." In Psychoanalysis and Politics: Exclusion and the Politics of Representation, edited by Lene Auested, 203-22. London: Karnac.

_ 2012b. "Some Social and Political Issues Related to Ferenczi and the Hungarian School." In Ferenczi and His World: Rekindling the Spirit of the Budapest School, edited by Judith Szekacs-Weisz and Tom Keve, 39-54. London: Karnac.

- 2014. "Freedom and Authority in the Clinical Diary" The American Journal of Psychoanalysis 74, 4: 367-80.

. 2017. "From war neurosis to Holocaust trauma. An intellectual and cultural history." In: S. I.M.O.N. Shoah: Intervention. Methods. Documentation 17(1): 41-58. Available at: https://simon-previous-issues.vwi.ac.at/images/Documents/ Issues/2017-1_SIMON/SIMON_2017-01.pdf [Accessed 4 December 2018].

_ 2018. "Against Violence: Ferenczi and Liberal Socialism." In Ferenczi's Influence on Contemporary Psychoanalytic Traditions, edited by Aleksandar Dimitriević, Gabriele Cassullo, and Jay Frankel, 248-54. London: Routledge.

— 2019. "Sándor Ferenczi, Géza Róheim, and the University of Budapest, 1918-19." Psychoanalysis and History 21, no. 1:5-22.

Erös, Ferenc, and Patrizia Giampieri. 1987. "The Beginnings of the Reception of Psychoanalysis in Hungary, 1900-1920." Sigmund Freud House Bulletin 11, no. 2: 13-28.

Ferenczi, Sándor. (1908) 1994. “Psychoanalysis and Education.” In Final Contributions to the Problems and Methods of Psycho-Analysis by Sándor Ferenczi, edited by Michael Balint, 280-90. London: Karnac.

_ 1911. "Az öntudatlan megismerése" [The discovery of the unconscious]. Szabadgondolat 1, no. 2: 75-78.

_. (1913a) 1994. "On Psychoanalysis and Its Judicial and Sociological Relevance." In Further Contributions to the Technique of Psychoanalysis by Sándor Ferenczi, edited by John Rickman, 424-35. London: Karnac.

_ (1913b) 1999. "Stages in the Development of the Sense of Reality." In Sándor Ferenczi: Selected Writings, edited by Julia Borossa, 67-81. London: Penguin.

—_. (1915) 1999. “The Ice-Age of Catastrophes.” In Sándor Ferenczi: Selected Writings, edited by Julia Borossa, 125-26. London: Penguin.

__ (1916) 1999. “Two Types of War Neuroses.” In Sándor Ferenczi: Selected Writings, edited by Julia Borossa, 129-44. London: Penguin.

_ـ (1922) 1999. "Psychoanalysis and Social Policy." In Sándor Ferenczi: Selected Writings, edited by Julia Borossa, 210-33. London: Penguin.

—_. (1924) 2005. Thalassa: A Theory of Genitality. London: Karnac, 2005.

— . (1932) 1988. The Clinical Diary, edited by Judith Dupont. Cambridge, MA: Harvard University Press.

__ (1933) 1999. “Confusion of Tongue between the Adults and the Child." In Sándor Ferenczi: Selected Writings, edited by Julia Borossa, 293-303. London: Penguin.

Freud, Sigmund. 1921. "Group Psychology and the Analysis of Ego." SE 18: 67-143. London: Hogarth.

Freud, Sigmund, and Karl Abraham. 2002. The Complete Correspondence of Sigmund Freud and Karl Abraham, edited by Ernst Falzeder. London: Karnac. 
Freud, Sigmund, and Sándor Ferenczi. 1993. The Correspondence of Sigmund Freud and Sándor Ferenczi. Vol. 1, 1908-1914, edited by Eva Brabant, Ernst Falzeder, and Patrizia Giampieri-Deutsch. Cambridge, MA: Harvard University Press.

— . 1996. The Correspondence of Sigmund Freud and Sándor Ferenczi. Vol. 2, 1914-1919, edited by Ernst Falzeder, Eva Brabant, and Patrizia GiampieriDeutsch. Cambridge, MA: Harvard University Press.

Fromm, Erich. (1935) 2000. “The Social Determinants of Psychoanalytic Therapy." International Forum of Psychoanalysis 9: 149-65.

Kolnai, Aurel. (1920) 2013. Psychoanalyse und Soziologie. Wien: Internationaler Psychoanalytischer Verlag.

- 1999. Political Memoirs. Lanham, Maryland, and Oxford: Lexington Books.

Lacan, Jacques. 2006. "The Mirror Stage as Formative of the Function of the $I$ as Revealed in Psychoanalytic Experience." In Écrits, translated by Bruce Fink, 75-81. New York: Norton.

Lukács, George. (1911) 1972. “On Poverty of Spirit: A Conversation and a Letter." The Philosophical Forum 3, nos. 3-4: 371-85.

Malabou, Catherine. 2009. Ontology of the Accident. London: Polity Press.

Musil, Robert. (1930) 1979. The Man without Qualities. Vol. 1. London: Pan Books. 


\title{
Sándor Ferenczi’s Epistemologies and Their Politics: \\ On Utraquism and the Analogical Method
}

\author{
Raluca Soreanu
}

\section{Utraquism and the Critique of the Sciences}

There are still many paths to explore when it comes to the epistemologies that are specific to the field of psychoanalysis. It is a worthwhile endeavor for psychoanalysts to ask questions about how knowledge is produced in their own field. But it is equally worthwhile for the social sciences more broadly, which are yet to discover all that psychoanalysis has to offer through its reflection on the encounter between the knower and the known. During the 1960s and 1970s, psychoanalysis was arguably lagging behind literary studies and the social sciences in terms of letting itself be transformed by the feminist movement and other movements for rights and forms of radical politics, with their profound epistemological implications. A closer look at the contributions of some of the early psychoanalysts, however, at the beginning of the twentieth century, can prove refreshing and can point to the radical edge of psychoanalysis.

In this chapter, I reflect on the epistemological underpinnings of some of Sándor Ferenczi's writings. As part of the Budapest intelligentsia at the turn of the century, Ferenczi received and filtered a number of radical ideas through his own clinical work. As a creative thinker, he proposed a series of innovations in psychoanalytic theory and technique around the notions of tact, empathy, and active technique. What is less acknowledged, however, is that his trauma theory and many of his other theoretical propositions are relevant not only for psychoanalysts. They also ground a political vocabulary. This is the case of his concept of utraquism (Utraquismus, Utraquistische Arbeitsweise), which I discuss below. 
Already at the turn of the twentieth century, Ferenczi was very hopeful about the possibilities for a less rigid and less dogmatic materialism that would permit the emergence of a productive psycho-physical parallelism (Ferenczi 1900). As I see it, it is from this early hopefulness that Ferenczi comes to develop the idea of the utraquism of the sciences over two decades later.

What is utraquism? Derived from the Latin utraque meaning "one and the other," it is the work of establishing relationships of analogy between distinct elements that belong to distinct fields of knowledge and strata of reality with the aim of discovering or going deeper into the meaning of certain processes (Ferenczi 1924b). For Ferenczi, utraquism is a method. It is an epistemologically consistent disposition.

Ferenczi borrowed this term from a sixteenth-century Protestant group, the Utraquists. What distinguished the Utraquists among the Protestants was their belief that it is not only the clergy that should have the privilege of taking both the bread and the wine during communion, but this symbolic reuniting of the flesh and blood of Christ should be extended to laity. As Martin Stanton (1990) notes, Ferenczi's interest in this term is quite a curious event in itself, given the fact that he was an agnostic Jew. I believe that Ferenczi's attraction to the Utraquists rests in his own strand of materialism, which is succinctly and poetically formulated in a 1921 essay: "[T]he symbol-a thing of flesh and blood" (Ferenczi 1921a, 352).

Ferenczi differentiates "unsubstantial allegory" from "the symbol." Not every analogy is symbolic in a psychoanalytic sense. The symbol emerges from a particular kind of affectively charged non-arbitrariness. First, the symbol has a physiological basis; it "expresses in some ways the whole body or its functions" (Ferenczi 1921a, 355). Second, one of the two terms (things, ideas) of the analogy, which can be considered symbolic, is invested in consciousness with an inexplicable overcharge of affect. This surplus of affect is rooted in the unconscious identification with another thing (or idea) to which it actually belongs. Construing analogies emerges as Ferenczi's method in both knowledge and healing.

One possible path into Ferenczi's analogical method would be to look at his 1924 work, Thalassa: A Theory of Genitality. Here, he speaks of bioanalysis, a science of origins, which affirms that every biological phenomenon also has a hidden meaning that can only be decoded via an interpretive path, where various overlaid historical strata are uncovered. In Thalassa, the principal phylogenetic-ontogenetic analogy is between the "intrauterine existence of higher mammals" and the type of existence characterizing the "aboriginal pi- 
scine period" (Ferenczi 1924, 45). As he puts, "birth itself [is] nothing but a recapitulation on the part of the individual of the great catastrophe which at the time of the recession of the ocean forced so many animals, and certainly our own animal ancestors, to adapt themselves to land existence" $(1924,45)$. Moving back and forth between ontogenesis and phylogenesis, Ferenczi elucidates the elements in his analogy:

The possession of an organ of copulation, the development within the maternal womb, and the circumvention of the great danger of desiccation-these three thus form an indestructible biological unity which must constitute the ultimate basis of the symbolic identity of the womb with the sea and the earth on the one hand, and of the male member with the child and the fish on the other. (Ferenczi 1924, 50)

In this chapter, I take a different path into Ferenczi's analogical method; I discuss a series of much smaller analogies embedded within his trauma theory and his conception of narcissism. Through a closer look at these analogies, we can arrive at a better understanding of Ferenczi's epistemological innovations.

In 1926, in "The Problem of the Acceptance of Unpleasant Ideas," Ferenczi makes an important connection between the stages in the development of the sense of reality in any individual and the development of the sciences:

As the last stage [in the development of the capacity for objectivity], that of insight derived from painful experience, I regarded the final and complete surrender of omnipotence-the scientific stage, so to speak, of our recognition of the world. In psycho-analytical phraseology, I called the first phase of all, in which the ego alone exists and includes in itself the whole world of experience, the period of introjection; the second phase, in which omnipotence is ascribed to external powers, the period of projection; the last stage of development might be thought of as the stage in which both mechanisms are employed in equal measure or in mutual compensation....

When ... I attempted ... to bring some light to bear critically on the manner in which our present-day science works, I was compelled to assume that, if science is really to remain objective, it must work alternately as pure psychology and pure natural science, and must verify both our inner and outer experience by analogies taken from both 
points of view; this implies an oscillation between projection and introjection. I called this the "utraquism" of all true scientific work. In philosophy ultra-idealistic solipsism means a relapse into egocentric infantilism; the purely materialistic psycho-phobic standpoint signifies a regression to the exaggerations of the projection-phase. (Ferenczi 1926, 373)

What we find in Ferenczi is a critique of science that is much ahead of its time. Ferenczi cautions against the perils of a medical science that proceeds rigidly by looking, as if hypnotized, into the microscope (1933, 146-147). Ferenczi also proposes a horizontal model of the encounter between the sciences, where each scientific discourse has the attribute of bringing insight into a particular semiotic code, while none of the codes is deemed superior. The final chapter of The Development of Psychoanalysis, co-authored by erenczi and Otto Rank, brings a utopia of the unification of the natural and mental sciences, with psychoanalysis taking up the role of making the integration. Even within this utopia, utraquism, oscillating between "one and the other" of the perspectives at hand, is central. We could argue that Ferenczi adopts a nomadic disposition in science, where knowledge is created by straying off from one point of perspective to another, from one stratum of reality to another. As he writes in his commentary on Freud's Group Psychology and the Analysis of the Ego, "[1]ooking at scientific advance as a whole, we see that direct, rectilinear advance keeps coming to a dead end, so that research needs to be resumed from a completely fresh and improbable angle" (1922, 371).

But what is perhaps most remarkable in Ferenczi's critique of scienceand what anticipates decades of feminist interventions and voices such as Sandra Harding (1986) and Donna Haraway (1988) — is that the act of making knowledge and the relationship to the object of study is seen as having its own erotics. What Ferenczi does is anchor his critique of science in his metapsychology, speaking of "the scientific stage" as one of the stages in the development of the sense of reality. The scientific stage is, by definition, the utraquistic oscillation between introjection and projection. It is the capacity of letting yourself be partly undone by the object, and then taking distance from it.

As early as 1915, Ferenczi was concerned with correcting the anthropocentric bias of the psychological sciences and preventing psychoanalysis from falling into the trap of naive animism. I read this as a thoroughly post-humanist disposition in Ferenczi: 
There is a safeguard ... against the psycho-analyst falling into the error of such naive animism. Naive animism transferred human psychic life en bloc without analysis on to natural objects. Psychoanalysis, however, dissected human psychic activity, pursued it to the limit where psychic and physical come in contact, down to the instincts, and thus freed psychology from anthropocentrism, and only then did it trust itself to evaluate this purified animism in terms of biology. (Ferenczi 1915, 256)

Ferenczi thus proves awareness of the dangers of working with psycho-physical parallelism as a preferred method in psychoanalysis. He nevertheless states that an analogical or utraquistic disposition is required from the psychoanalyst in their work. Mere observation of the attitude or the behavior of the patient is not sufficient. What is needed is an untiring sensitivity to the patient's ideational associations, his emotions, and his unconscious process. To achieve this sensitivity, the psychoanalyst relies on the flexibility and the plasticity of their own mind (Ferenczi 1933, 153).

\section{Ferenczi’s Biological Metaphors}

Some of Ferenczi's most important and original ideas on trauma are built around a series of biological analogies. What is remarkable is how Ferenczi records vignettes on animal behavior; how he humbly learns from them; and how he construes the psychoanalytic observations in dialogue with them, in the spirit of a clinical empiricism. Meaning springs from his own utraquistic oscillation between the examples in biology (or sometimes chemistry or physics) and his thesis in trauma theory. We can argue that his metapsychology is the fruit of these forms of utraquistic elucidation. This type of minute observation of animals and cells is close in spirit to that of philosophers and social theorists such as Donna Haraway (1976), Gregory Bateson (1979), and Félix Guattari (2011) in the sense of acknowledging the plurality of semiotic codes that traverse the living being. I am, therefore, not insisting that Ferenczi's theory of trauma has a biological substratum, but rather that Ferenczi is able to take insights from biology through his own utraquistic method.

In what follows, I will discuss three of these biological vignettes: the first one is about animals who leave behind wounded parts of their bodies and Ferenczi's original and illuminating system of terms alloplastic adaptation/autoplastic adaptation, autosymbolism, and autotomy; the second one concerns 
the creation of new organs and Ferenczi's ideas on the relationship between creation and destruction; and the third one is about the teratoma, the growth of a tumor, which Ferenczi uses as a crucial image for the elaboration of his conception of narcissism.

\section{“BITING OFF A PAINFUL LEG”: AUTOTOMY}

There are two kinds of responses of the ego to the trauma for Ferenczi. The first one, corresponding to a highly developed sense of reality, he terms "alloplastic adaptation," which means that the ego is able to alter the environment, the world outside, in such way that self-destruction and self-reconstruction are not necessary, and the ego maintains its equilibrium (1930a, 221). The second one he calls "autoplastic adaptation," which means that the ego does not have or loses its capacity to mold the external world, and proceeds to operate on itself.

Perhaps the most tragic form of autoplastic adaptation is autotomywhere the ego cuts off, fully detaches, and leaves a part of itself behind. It is here that Ferenczi relies on the image of the animal shedding a body part that has been wounded-let us think of lizards cutting off their tails or mammals known to bite off a painful leg. In "Psycho-analytical Observations on Tic," Ferenczi writes:

Here I will touch on the analogy of the third kind of tic, i.e., the motor discharge ("turning against one's own person," Freud), with a method of reaction that occurs in certain lower animals, which possess the capacity for "Autotomia." If a part of their body is painfully stimulated they let the part concerned "fall" in the true sense of the word by severing it from the rest of their body by the help of certain specialized muscular actions; others (like certain worms) even fall into several small pieces (they "burst asunder," as it were, from fury). Even the biting off of a painful limb is said to occur. (Ferenczi 1920, 160)

In one of the entries of the Clinical Diary, Ferenczi introduces another curious vignette on animal behavior, when the adaptation to the anticipation of unbearable pain is suicide:

As an analogy I refer to a reliable account of an Indian friend, a hunter. He saw how a falcon attacked a little bird; as it approached, the little bird started to tremble and, after a few seconds of trembling, flew 
straight into the falcon's open beak and was swallowed up. The anticipation of certain death appears to be such torment that by comparison actual death is a relief. (Ferenczi 1932, 179)

Ferenczi derives crucial metapsychological reflections from these images. In the first one on autotomia, we see "an archaic prototype of the components of the masochistic instinct" $(1920,161)$. In the second one, we see the limits of passivity and a certain primacy given to activity, in that an active death is preferred to the anticipation of complete surrender to the aggressor.

\section{LOEB'S FERTILIZED EGGS: DESTRUCTION, CREATIVITY, AND THE CREATION OF NEW ORGANS}

Ferenczi is aware of the importance of the point of contact between autoplastic and alloplastic adaptations for clinical thinking. In other words, he observes how self-fragmentation and splitting are at times bound up with the creation of new organs and new capacities, or, as he calls them, "neoformations." In his 1926 essay on "The Problem of the Acceptance of Unpleasant Ideas" (1926, 377), he discusses how certain kinds of self-destruction lead to an enlarged recognition of the surrounding world and draw us closer to the formation of objective judgement. Here Ferenczi cites Sabina Spielrein's (1912) paper on destruction as a "cause of being," which is in itself notable given the lack of acknowledgement of her ideas at the time, and also the fact that her ideas, as Adrienne Harris (2015) notes, seem to have been absorbed rather than referenced, turning her into a ghost rather than an ancestor. Resonating with Spielrein, Ferenczi argues that a partial destruction of the ego is tolerated, but only for the purpose of constructing a stronger and more resilient ego from that which remains. We here encounter another biological analogy. He writes:

This is similar to the phenomena noted in the ingenious attempts of Jacques Loeb to stimulate unfertilized eggs to development by the action of chemicals, i.e. without fertilization: the chemicals disorganize the outer layers of the egg, but out of the detritus a protective bladder (sheath) is formed, which puts a stop to further injury. In the same way the Eros liberated by instinctual defusion converts destruction into growth, into a further development of the parts that have been protected. (Ferenczi 1926, 377) 
As he notes four years later in 1930, in a short writing on "Trauma and Striving for Health," fragmentation as a result of trauma does not appear to be a sort of mechanical consequence of shock; instead, it is already a form of defense, an adaptation. Here too, he makes another analogy with lower animals, which, subjected to extreme stimulation, break up and continue their existence in fragments. He goes on to imagine the logic of defense by splitting. As he writes:

Fragmentation may be advantageous (a) by creating a more extended surface towards the external world, i.e. by the possibility of an increased discharge of affects; (b) from the physiological angle: the giving up of concentration, of unified perception, at least puts an end to the simultaneous suffering of multiple pain. The single fragments suffer for themselves; the unbearable unification of all pain qualities and quantities does not take place; (c) the absence of higher integration, the cessation of the interrelation of pain fragments allows the single fragments a much greater adaptability. (Ferenczi 1930b, 230)

The connections that Ferenczi makes between destruction, creativity, and the creation of new organs should not, however, seduce us into a celebration of fragments, a sort of enthusiasm for a post-catastrophic subjectivity that emerges from Ferenczi's work. Ferenczi remains lucid about the dark implications of splitting, which pass through a particular kind of narcissism where the deadened fragments of the ego are denied. The ego becomes a kind of mosaic of dead and still-alive parts, but the deadened and de-libidinized ones are "forgotten." Some of the fragments "assume, as it were, the form and function of a whole person" (1930c, 222). Here, Ferenczi construes another analogy with the animal world. As he writes in "Child Analysis in the Analysis of Adults":

I have been told little tales like the one about the wicked animal which tries to destroy a jelly-fish by means of its teeth and claws, but cannot get at it because the jelly-fish with its subtleness eludes each jab and bite and then returns to its round shape. This story may be interpreted in two ways: on the one hand it expresses the passive resistance with which the patient meets the attacks of his environment, and on the other it represents the splitting of the self into a suffering, brutally destroyed part and a part which, as it were, knows everything but feels nothing. (Ferenczi 1931, 135) 
In the analytical situation, the traces of this sort of splitting resurface when the patient feels hurt and disappointed, and as a result "he starts playing by himself like a lonely child" (Ferenczi 1931, 135). It seems that a part of the person is able to take up the role of mother or father in relation to the whole. As Ferenczi tells us:

In this play various parts of the body-hands, fingers, feet, genitals, head, nose, or eye-become representatives of the whole person, in relation to which all the vicissitudes of the subject's own tragedy are enacted and then worked out to a reconciliatory conclusion. It is noteworthy, however, that over and above this we get glimpses into the processes of what I have called the "narcissistic split of the self" in the mental sphere itself. (Ferenczi 1931, 135)

Ferenczi's biological analogies allow him to extend his trauma theory and to observe that new faculties emerge at the time of the trauma. This opens new paths in psychoanalytic theory in terms of how we think of repair and how the "new organs" created in traumatic times can be part of this repair.

\section{TERATOMA, THE DOUBLE INSIDE, AND (DEATH) NARCISSISM}

One of Ferenczi's most powerful medical analogies-and one that I would argue has yet to reveal all its richness for understanding trauma and narcissism-is that between neurotic functioning and a teratoma, that is the growth of a tumor. In his 1929 paper, "The Principle of Relaxation and Neocatharsis," Ferenczi notes:

For it is no mere poetic licence to compare the mind of the neurotic to a double malformation, something like the so-called teratoma which harbours in a hidden part of its body fragments of a twin-being which has never developed. No reasonable person would refuse to surrender such a teratoma to the surgeon's knife, if the existence of the whole individual were threatened. (Ferenczi 1929, 123)

It is worth noting that Georg Groddeck (1923) used a similar term in a literary context, when he spoke of "horror stories": teratomae were a particular type of monster, either constructed from parts of different bodies like Frankenstein, or the result of fantasy and the transformations of the body that fan- 
tasy brings (Stanton 1990, 174). The implications of the Ferenczian teratoma are, however, much broader. Ferenczi argues that in some cases of neurosis (often as a result of profound trauma in infancy), the greater part of the personality becomes a teratoma, while the task of adaptation to reality falls upon the (smaller) fragment of the personality that was spared. I would argue that the work of the psychoanalytic process is to deal with this very disproportion, where the deadened twin-being occupies most of the psychic space. This is perhaps the Ferenczian uncanny: a meeting with the "twin-inside." The act of the (Ferenczian) narcissist is that of denying the existence of the teratoma.

The teratoma can also be subject to a politicized reading: it is Ferenczi's version of alienation. The primary alienation is the confusion of tongues between children and adults, where the language of passion-the register of adult sexuality, which has known repression and guilt-intrudes into the language of tenderness - an experimental, playful, and expansive register. Later in life, all ideological seductions that succeed in bringing submission and alignment appeal to this initial seduction. Ideology needs the teratoma, the dead "twin-inside," the parasitic formation that is bred in the unconscious. The teratoma creates "introspective blindness," which is preserved through moralizing education. Through the "prohibiting and deterring commands of moralising education" (Ferenczi 1908, 287), the person settles into a state akin to that of hypnosis, with diminished mental energies flowing into the conscious part of the ego and a considerably impaired capacity for action.

\section{Conclusions}

The psychoanalyst emerges from Ferenczi's works as a maker and holder of analogies. These analogies pertain to the sphere of theoretical construction, but also to the sphere of healing. The psychoanalyst establishes analogies between different strata of reality, but she also contains the analogies of the patient. Furthermore, the psychoanalyst induces the patient into the art of making analogies. A completed analysis, for Ferenczi $(1928,99)$, is one where the elasticity of the analyst's mind extends to the patient.

As I have shown, Ferenczi's writings point to an erotics of objectivism and offer important insights on horizontalizing the encounter between the knower and the known. As he writes: "The last and logically irrefutable word of the pure intellectuality of the ego on the relationship to other objects is a solipsism, which cannot equate the reality of other living beings and the 
whole outside world of personal experience, and speaks of them as more or less living phantoms or projections" (1921b, 229). The alternative to this kind of solipsism is what he calls "conviction." Conviction, as opposed to mere belief, cannot be derived solely from logical insight. Instead, it needs to be lived as an affective experience and even felt in one's body (Ferenczi 1912, 193-194). In other words, it is embodied knowledge. Through this conception of felt knowledge, Ferenczi proved to be a thinker ahead of his time, anticipating epistemological ideas that would be articulated by feminist voices decades later.

\section{REFERENCES}

Bateson, Gregory. 1979. Mind and Nature: A Necessary Unity. New York: Dutton.

Ferenczi, Sándor. (1900) 1994. "Conscience et développement." In Les écrits des Budapest, 63-70. Translated by Györgyi Kurcz and Claude Lorin. Paris: E.P.E.L.

_ (1908) 1994. "Psycho-analysis and Education." In Final Contributions to the Problems and Methods of Psychoanalysis, 280-90. Translated by Eric Mosbacher. London: Karnac Books.

_ . (1913) 1994. "Transitory Symptom-constructions during the Analysis." In First Contributions to Psychoanalysis, 193-212. Translated by Ernest Jones. London: Karnac Books.

. (1915) 1994. "The Scientific Significance of Freud's 'Three Essays on the Theory of Sexuality." In Further Contributions to the Theory and Technique of Psychoanalysis, 253-56. Translated by Jane I. Suttie. London: Karnac Books.

_ _ (1920) 1994. "Psycho-analytical Observations on Tic." In Further Contributions to the Theory and Technique of Psychoanalysis. Translated by Jane Isabel Suttie, 142-74. London: Karnac Books.

. (1921a) 1994. "The Symbolism of the Bridge." In Further Contributions to the Theory and Technique of Psychoanalysis, 352-56. Translated by Jane Isabel Suttie. London: Karnac Books.

_ (1921b) 1994. "Contra-indications to the 'Active' Psychoanalytic Technique." In Further Contributions to the Theory and Technique of Psychoanalysis, 217-30. Translated by Jane Isabel Suttie. London: Karnac Books.

. (1922) 1994. "Freud's 'Group Psychology and the Analysis of the Ego." In Final Contributions to the Problems and Methods of Psychoanalysis, 371-76. Translated by Eric Mosbacher. London: Karnac Books.

— . (1924) 1938. Thalassa: A Theory of Genitality. Translated by Henry Alden Bunker. New York: Psychoanalytic Quarterly.

. (1926) 1994. "The Problem of Acceptance of Unpleasant Ideas: Advances in Knowledge of the Sense of Reality." In Further Contributions to the Theory and Technique of Psychoanalysis, 366-79. Translated by Jane Isabel Suttie. London: Karnac Books. 
(1928) 1994. “The Elasticity of Psychoanalytic Technique.” In Final Contributions to the Problems and Methods of Psychoanalysis, 87-101. Translated by Eric Mosbacher. London: Karnac Books.

- (1929) 1994. “The Principle of Relaxation and Neocatharsis." In Final Contributions to the Problems and Methods of Psychoanalysis, 108-25. Translated by Eric Mosbacher. London: Karnac Books.

_ (1930a) 1994. "Autoplastic and Alloplastic Adaptation." In Final Contributions to the Problems and Methods of Psychoanalysis, 231. Translated by Eric Mosbacher. London: Karnac Books.

_ . (1930b) 1994. “Trauma and Striving for Health.” In Final Contributions to the Problems and Methods of Psychoanalysis, 230-31. Translated by Eric Mosbacher. London: Karnac Books.

_ (1930c) 1994. “On the Analytic Construction of Mental Mechanism.” In Final Contributions to the Problems and Methods of Psychoanalysis. Translated by Eric Mosbacher, 221-23. London: Karnac Books.

— . (1931) 1994. "Child Analysis in the Analysis of Adults." In Final Contributions to the Problems and Methods of Psychoanalysis, 126-42. Translated by Eric Mosbacher. London: Karnac Books.

—_ (1932) 1995. The Clinical Diary of Sándor Ferenczi. Edited by Judith Dupont. Translated by Michael Balint and Nicola Zarday Jackson. Cambridge, MA: Harvard University Press.

— . (1933) 1994. "Freud's Influence on Medicine." In Final Contributions to the Problems and Methods of Psychoanalysis, 143-55. Translated by Eric Mosbacher. London: Karnac Books.

Ferenczi, Sándor, and Otto Rank. (1924) 1925. The Development of Psychoanalysis. Translated by Caroline Newton. New York: Nervous and Mental Disease Publishing Company.

Groddeck, Georg. (1923) 1965. The Book of the It. New York: Vintage.

Guattari, Félix. 2011. The Machinic Unconscious: Essays in Schizoanalysis. Translated by Taylor Adkins. Los Angeles: Semiotext(e).

Haraway, Donna J. 1976. Crystals, Fabrics, and Fields: Metaphors of Organicism in Twentieth-Century Developmental Biology. New Haven and London: Yale University Press.

_ 1988. "Situated Knowledges: The Science Question in Feminism and the Privilege of Partial Perspective." Feminist Studies 14, no. 3: 575-99.

Harding, Sandra G. 1986. The Science Question in Feminism. Cornell University Press. Harris, Adrienne. 2015. "'Language Is There to Bewilder Itself and Others': Theoretical and Clinical Contributions of Sabina Spielrein." Journal of the American Psychoanalytic Association 63, no. 4: 727-67.

Spielrein, Sabina. (1912) 1994. "Destruction as the Cause of Coming into Being." Journal of Analytical Psychology 39, no. 2: 155-86.

Stanton, Marton. 1990. Sándor Ferenczi: Reconsidering Active Intervention. London: Free Association Books. 


\title{
"Tell Them That We Are Not Like Wild Kangaroos": Géza Róheim and the (Fully) Human Primitive
}

\author{
Shaul Bar-Haim
}

Psychoanalysis has stood at the center of the post-colonial critique since the emergence of this discourse after World War II. However, while scholars such as Franz Fanon in the 1950s and 1960s drew heavily on psychoanalytic notions to reveal the epistemology of the colonial gaze (Fanon 1967), since the 1980s, other scholars attacked psychoanalysis itself as a paradigmatic case study of Europocentric social science (Nandy 1995; Deleuze and Guattari 1988; Seshadri-Crooks 1994; Khanna 2003; Brickman 2003; Said 2004; Anderson, Jenson, and Keller 2011). Post-colonial literature has shown the importance of nineteenth-century anthropology in the development of Freudian thought, particularly in Freud's speculative cultural writings on the pre- and early-history of humanity, and especially Totem and Taboo. In this and other works, scholars have shown that Freud was a loyal follower of Darwinian anthropologists such as Edward B. Tylor and James G. Frazer. They argued that so-called "primitive" people are living evidence of the early stages of the human being. For nineteenth-century British anthropologists, "they" (primitive people) are what "we" (progressive, civilized people) used to be thousands of years ago. ${ }^{1}$

1 According to the Oxford English Dictionary, a "primitive" could be, among other things, "a firstborn child or animal"; "an ancestor or progenitor"; "a predecessor"; "an original inhabitant, an aboriginal"; "a person belonging to a preliterate, nonindustrial society"; "that which is primitive or recalls an early or ancient period"; "(with pl. concord) simple, unsophisticated, or crude things or people as a class"; 
As Freud observed on the very first page of Totem and Taboo:

There are men still living who, as we believe, stand very near to primitive man, far nearer than we do, and whom we therefore regard as his direct heirs and representatives. Such is our view of those whom we describe as savages or half-savages; and their mental life must have a peculiar interest for us if we are right in seeing in it a well-preserved picture of an early stage of own development. (Freud [1913] 1955, 1)

However, in order to understand the context to Freud's perceptions of the "primitive," we should bear in mind that for nineteenth-century anthropology, "primitives" were never just the concrete objects of study. As Johannes Fabian pointed out, the primitive was always "a category, not an object, of Western thought" (Fabian 1983, 17-18). The usage of the "primitive" as a category was not limited to certain people in certain geographical areas, but a normative scale for cultural, ethical, and mental development and progress. As will be discussed later in this chapter, it was not only non-Westerners who were perceived as "primitive"; children, mentally-ill, "degenerate" people, and even working-class people were all widely considered to have a "primitive" mind. Thus, the "primitive" state was a phase of development for individuals and collectives rather than a description of specific societies. Early psychoanalysts, such as Freud, Sándor Ferenczi, and Ernest Jones embraced these perceptions by all means (Jones 1920, 257; Freud [1916-1917] 1963, 371; Ferenczi 1913, 213). However, Géza Róheim, the focus of this chapter, was in many respects an exception to the general opinion of early-twentieth century psychoanalysis about the category of the "primitive." Róheim, I argue, attempted to change the way in which this category of the "primitive" was perceived as a category denoting a not-fully-human subject.

Before discussing the originality of Róheim's understanding of the "primitive," we must first discuss a fundamental similarity between him and other nineteenth-century social thinkers. A main trigger for Róheim's expedition to Central Australia was the refutation of Bronisław Malinowski’s claim that

and "an uncivilized, unintelligent, or uncouth person." The word "primitive" has been in use in English since the fifteenth century, but it was not central to colonial discourse until the mid-nineteenth century, when Darwinian anthropology became dominant. It was only then that the "primitive" replaced as the key notion what was hitherto known as the "savage." See Kuper 1988 and Trautmann 1992. 
the Oedipus complex is not a universal phenomenon and cannot be found, for instance, in non-Western matrilineal societies (Smadja 2011). Róheim was sent by the interwar psychoanalytic community to defend not only the validity of the Oedipus complex as universal, but also as one of the core notions of nineteenth-century social science: the idea of the universal nature of science, i.e., that human nature is similar in all places, and therefore, that beyond the surface of culture and history, people everywhere are similar in their motivations and behavior. Universalism was a pivotal principle in the emergence of modern politics as it served as the precondition for what Étienne Balibar defined as "civic universalism," or the "adequacy between the capacities of the human and the powers of the citizen" (Balibar 2012, 208). If-and only ifone can be defined as fully human, one is entitled to become a citizen with full rights. When this equation between humanness and citizenship became the rule, Balibar claims, "the only consistent way to deny citizenship to individuals in a regime of civic-bourgeois universality is to deny them full humanness, full membership in the human species" (208).

Biology and anthropology played central roles in this process of affirming and denying "full humanness." Thus, for instance, colonial hierarchies were created not only by political, economic, and military imperial powers, but also by scientific comparisons of the "primitive" and the "civilized" in order to argue that the latter is a "developed" version of the former. ${ }^{2}$ Many strands of Victorian anthropology, which was highly influenced by evolutionary theories, perceived the "primitive" and the "civilized" as belonging to the human spectrum and measurable by the same scales, which are universalistic. However, while the "civilized" is fully human, the "primitive" is still in the process of becoming a human, and thus cannot be entitled to his or her full rights (Kuper 1988). The innovation of Géza Róheim, at least in psychoanalytic discourse, was that although he did not challenge the principle of universalism itself, he insisted on attributing "full humanness" to the subjects he studied, namely, the "primitives."

${ }^{2}$ Since the eighteenth century, many different European thinkers such as Montesquieu, Hume, Knox, and Gobineau perceived the "civilized" as the last and final stage in the evolutionary process of collectives and individuals. The three main stages of this process were the "savage," followed by the "barbarian," and ending with people becoming fully reasoned persons, i.e., "civilised." I am very grateful to Simon Jarrett for sharing this information with me. See also Jarrett 2016.

3 See also Linstrum (2016, Chapter 2), for another interwar Freudian anthropologist, C.G: Seligman, who attempted to prove the universality of the psychoanalytic principles by collecting and analyzing dreams from all over the British Empire. 
Róheim changed several of his pre-expedition views during his fieldwork, but he did not give up the idea that the Oedipal structure is universal and can also be found among "primitives." Like Jones before him, he argued that Malinowski failed to recognize the flexibility of the Oedipus structure to fit into different forms of domesticity in different societies and cultures. Freud, Jones argued, "regards the relationship between father, mother, and son as the prototype from which other more complicated relationships are derived" (Jones 1925, 127). This "prototype," Jones and others in the psychoanalytic community thought, can be found in patriarchal and matriarchal (or matrilineal) societies alike.

But for Róheim, the debate over Oedipus was not only a scientific issue, but something to do with the very essence of humanness. He writes: "we are human beings because we have an Oedipus complex, but our individuality depends on the early developments of this nucleus, on the specific traumata we have suffered or courted" (Róheim 1932, 92). Therefore, Róheim attempted to show that the Oedipus complex is a dominant factor in the psychosocial development of "primitive" people. As historian Joy Damousi claimed recently, "in arguing that the self was universal, Róheim was positioning the unconscious of the indigenous self as a subject worthy of analysis and interrogation and not an inquiry to be dismissed as simple-minded or childlike" (Damousi 2011, 93). But at the same time, he aimed not to reduce indigenous peoples and their unique culture into a prototype of the common Western model of domesticity, but to present them as another model of the "human," indeed, the "fully human." This effort does not make them less "primitive" or more "progressed"; it changes the epistemological perspective of the researchers.

\section{II}

Even though Róheim was a loyal follower of the nineteenth-century universalistic approach - and did not follow Malinowski's new relativistic approach - he still challenged the fundamental assumption of his anthropological predecessors that the "savage" necessarily has a less-developed mind, and therefore he or she are less rational. He writes:

My first impression during my field work was that savages are not nearly so savage as the anthropologists; or in other words, that they are not nearly so mysterious as one would think from reading Tylor, 
Frazer, Levy-Brühl, or even Róheim. Because we read so much about animism and magic, totemism and demons, we come to identify primitive people with these things unintentionally and to imagine them as always plagued by demons, or running into taboos, and passing their lives in a chronic state of terror. Similarly, if we only knew Europe from the Catechism, the Talmud, and the books of Folklore, we might easily imagine that the main occupations of the inhabitants of this continent were confessing, fasting, and telling fairy tales and legends. (Róheim 1934b, 238)

For Róheim, the idea that the "primitive" is irrational was not only an expression of observers' ignorance, but also a clear sign of their lack of self-reflection. The professional danger of an anthropologist's fieldwork, he thought, is that "as he slowly overcomes the feeling of strangeness in his new environment, the sorcerer and cannibal becoming as commonplace acquaintances as his school friends. . . . Instead of a group of uncanny beings, he now sees an idyll of the type imagined by Rousseau" (Róheim 1932, 2). Róheim compares this nonreflective observer to a psychoanalyst who works only with transference, and is not aware of the existence of countertransference in his or her work (16-18).

No one was more sensitive to the epistemological asymmetry between the native and his or her Western observer than natives themselves. As one of Róheim's informants told him: "you have seen our land, our houses, our customs, but we do not know your country. When you go home, tell them (the whites) that we are not like wild kangaroos, eaters of rotten wood, but have our customs and habits also" (Róheim 1932, 276). Indeed, on top of Róheim's scientific mission, he now realized that he had another moral commitment to his informants: to help them become "fully human" in the eyes of his anthropologist colleagues. ${ }^{4}$ In other words, exploring the Oedipal structure of their society-the specific form that this structure takes place among Central Aus-

4 Róheim, however, had his own blind spots. For example, he was unaware of, or refused to see, the removal of indigenous children from their families in order to give them to white families (what was known later as the "stolen generation"), even though these child abductions were happening in some of the places that he visited during the same periods. Warwick Anderson argues that "[e]ven as Cecil Cook planned the removal of mixed-race Aboriginal children from their families, Róheim was insisting their separation anxieties were internal manifestations of the universal family drama, thereby exonerating the settler state. ... Striving to make a general argument against the psychic cost of 'civilization, Róheim had turned a blind eye to 
tralian natives-was his way of including them as human living subjects who needed to be respected as such, rather than excluding them from humanity as part of a living "museum" in the form of "primitive" tribe; or, alternatively, excluding them from humanity because their "primitiveness" is evidence that they are not fully human yet.

Róheim did not abandon the term "primitive" altogether, but he tried to fill it with a different ethical meaning in the lexicon of Westerners. He probably would not deny, for example, that civilized people are more progressed than "primitives." However, he believed that progress is not an ethical value in itself (Bar-Haim 2015). Moreover, he thought that being primitive or nonprogressed should not be a factor in denying one's fully humanness. Indeed, he would probably fully agree that "primitive" is a category of thought rather than a specific object of study, as Fabian suggested.

\section{III}

For Róheim, "only my friends of the Central Australian desert can be described as primitives in the true sense of the word" (Róheim 1932, 4). All other "primitives" that he knew of (Somali, Papuo-Melanesians, Yuma Indians) "are closer to us psychologically than to the Australians." Thus, there are a few degrees of primitives, and only few pure "primitive" peoples left. The main distinctive characters of the "primitive," all of which Central Australians have, and the rest only few, are: 1) absence of the latency period; 2) "slight depth of repression with rapidly ensuing projection"; 3) total absence of the anal-reactive character-formation; 4) "the strength of their narcissism"; and 5) "the absence of the sado-masochistic perversion." Due to the limits of space, I will restrict myself to discuss the first parameter of the lack latency period among "primitive" people. This lack of latency period, Róheim argued, is not

the real damage it wrought in central Australia. Rather than a costly defense against object loss, civilization might be its cause" (Anderson 2014, 142). On the "stolen generation," see Jacobs 2011. On the role of denial in Austalian settler society, see Attwood 2017.

${ }^{5}$ For Róheim, all these parameters are casually connected to each other: in short, the latency period in civilized children is the source of repressions and aggressions, and therefore the absence of it is the reason for the lack of sadistic perversions among "primitive" people. 
limited to non-Western "primitive" people but can be found everywhere, like primitivism itself. Thus, the "primitive" cannot serve as a category used to deny "full humanness."

Let us remind ourselves what the latency period is. Laplanche and Pontalis define the latency period (the time which extends from the age of five or six to the onset of puberty) as a phase "constituting a pause in the evolution of sexuality," that is, "a decrease in sexual activity, the desexualisation of object-relationships and of the emotions," and "the emergence of such feelings as shame and disgust along with moral and aesthetic aspirations" (Laplanche and Pontalis 1973, 234). With the dissolution of the Oedipus complex, the child fully identifies with his or her parents and represses any libidinal struggle he or she had with them in the years before. The sexual content, which was so dominant in the Oedipal phase, is now sublimated, and paves the way for full formation of the super-ego. In other words, the latency period is the outcome of the dissolution of the defeat of the child in the Oedipal struggle against his or her parents. The child gives up his incestuous desires for the unconscious, i.e., the child sublimates these desires, and is now ready to obey to the social contract, represented at this stage mainly by the parents.

However, according to Róheim, "the latency period, which is the time of full super-ego formation in our own civilization, is absent or only faintly indicated among the most primitive races of mankind" (Róheim 1934a, 406). Thus, in some respects, childhood in Central Australia is much longer. For instance, child's breastfeeding is much longer; repressions and sublimations of sexual content are much more limited. But in a "primitive" condition, when childhood ends, puberty comes; there is no prolongation of childhood in the form of latency period, which creates the psychosocial conditions for the "non-primitive" children to gain a "cultural progress":

If we compare various races, people, and phases of culture with each other, the prolongation of infancy proceeds pari passu with cultural progress. The races which play a leading part in civilization arrive at puberty much later than primitive mankind. The situation is the same if we regard it not from the biological but from the sociological or psychological point of view. A Pitchentara child attains a considerable degree of economic independence when he or she is about six or seven years old. A Papuan child helps his father and mother with the garden work, has a little garden of his own, and in Duau at the age of 
ten a house of his own. But we find the same difference at home if we compare the children of the peasant class or proletariat with those of the aristocracy or rich bourgeoisie. (Róheim 1934a, 403)

Primitiveness, then, can be found everywhere, claims Róheim. There is nothing new in itself in Róheim's comparison between "primitive" people in colonies and the "primitive" at home. In his book, Faces of Degeneration, the historian Daniel Pick writes: "the object of the racial anthropology which emerged in [the late nineteenth century] was not only Africa or the Orient, but also the 'primitive' areas and groups within the home country" (Pick 1989, 39). Not only anthropologists but many other nineteenth-century scholars from the social and natural sciences thought of "primitive," "regressive," "atavistic," or "degenerate" people as a central component of European society. Moreover, many of them believed that these people endanger the "progressive" tendency of modernization as a whole (ibid.) Indeed, the flourishing of sciences that articulated these racial languages is the appropriate context to understand the rise of racial politics in late nineteenth-century and early twentieth-century Europe (see Pick 1989; Gilman 1985; MorrisReich 2006).

But one could adopt the same terminology of the "primitive" and reach very different conclusions. For example, Róheim did not try to refute the notion of the "primitive" altogether, as some of his contemporary anthropologists did. He still assumed that the children of the "peasants class or proletariat" are as fully human as the children of the "aristocracy or rich bourgeoisie." Thus, he also assumed that colonized "primitive" children, despite their primitiveness, are fully human too. ${ }^{6}$

We can now see more clearly how Róheim used the "primitive" in his work as a category of Western thought rather than a specific object of study. As such, it was applicable for Central Australian children and the children of the lower classes in Europe alike; both, in some respects, were considered "primitives." For example, both types of children lack a latency period as part

${ }^{6}$ Children, like "primitives," who were very often compared by nineteenth-century social and natural scientists, were considered throughout the nineteenth century as not fully human. Indeed, childhood itself, like the "primitive" state, was perceived as a phase in the process of becoming fully human, a process which "primitive" people failed to do. See Stoler $(1995,150)$ and Nandy (1984). For the distinction between "human beings" and child "human becomings", see Qvortrup et al. (1994, 1-23). 
of their development; but also, both types of children, like all other children in the world, Róheim believed, had to go through an Oedipus complex. He thought of these two developmental phases as essentially different. The Oedipus was regarded as part of the human condition as such, while the "latency period" was specific to certain social and individual conditions. Thus, for Róheim, the Oedipal structure was part of being human, and therefore can be found in any society, including "primitive" ones. The existence or lack of a latency period as a specific developmental phase varied from one society to another, and therefore cannot deny one's "full humanness."

One may argue that this typology is not only essentialist but also simplistic and arbitrary in its insistence that the Oedipus complex is universal while other developmental stages like the "latency period" are different and influenced by culture and history. However, the point to be made for our purposes is that Róheim thought of the "primitive" as a category rather than an object, which should not deny one's "full humanness," as nineteenth-century traditions of social sciences implied. Róheim's effort, therefore, challenged the political consequences of what Balibar called "anthropological differences": the "differences perceived among humans that are also immediately constitutive of the idea of the human" (Balibar 2012, 208-209). As Balibar argues, the constitution of the "human" is inevitably violent because the moment one defines "humanness," one also excludes the "other" as "non-human": for example, in the form of "black," "insane," "pervert," "primitive," and so on. For Róheim, I argue, the aim was not to "humanize" the "primitive" — a task doomed to fail-but to accept "primitiveness" as a legitimate dimension of the "human"; indeed, the fully human.

\section{ACKNOWLEDGMENTS}

I would like to thank Danae Karydaki, Manuel Batsch, Simon Jarrett, Carolyn Laubender, and Johanna Römer for reading earlier drafts of this paper, and for all their helpful suggestions.

This chapter appeared first in a slightly different version as "Tell them that we are not like wild kangaroos': Géza Róheim and the (fully) human primitive," in Joanny Lelong and Samuel Rambaud (eds.), E. Pichon-Rivière, Av. Santa Fe 1379, Buenos Aires. G. Róheim, Hermina ut 35 b, Budapest. Villeurbanne, France: Nouveau Document. I wish to thank the editorial board of Nouveau Document, and especially Joanny Lelong, for permitting this re-publication. 


\section{REFERENCES}

Anderson, Warwick. 2014. "Hermannsburg, 1929: Turning Aboriginal 'Primitives' into Modern Psychological Subjects." Journal of the History of the Behavioral Sciences 50, no. 2: 127-47.

Anderson, Warwick, Deborah Jenson, and Richard C. Keller, eds. 2011. Unconscious Dominions: Psychoanalysis, Colonial Trauma, and Global Sovereignties. Durham, N.C.: Duke University Press.

Attwood, Bain. 2017. "Denial in a Settler Society: The Australian Case." History Workshop Journal 84, no. 1: 24-43.

Balibar, Étienne. 2012. "Civic Universalism and Its Internal Exclusions: The Issue of Anthropological Difference." boundary 2, no. 39: 207-29.

Bar-Haim, Shaul. 2015. “The Maternalizing Movement: Psychoanalysis, Motherhood and the British Welfare State c. 1920-1950." PhD Dissertation. Birkbeck, University of London.

Brickman, Celia. 2003. Aboriginal Populations in the Mind: Race and Primitivity in Psychoanalysis. New York: Columbia University Press.

Damousi, Joy. 2011. "Géza Róheim and the Australian Aborigine: Psychoanalytic Anthropology During the Interwar Years." In Unconscious Dominions: Psychoanalysis, Colonial Trauma, and Global Sovereignties, edited by Warwick Anderson, Deborah Jenson, and Richard C. Keller, 75-95. Durham: Duke University Press.

Deleuze, Gilles, and Félix Guattari. 1988. A Thousand Plateaus: Capitalism and Schizophrenia. London: Athlone Press.

Fabian, Johannes. 1983. Time and the Other: How Anthropology Makes Its Object. New York: Columbia University Press.

Fanon, Frantz. 1967. Black Skin, White Masks. New York: Grove Press.

Ferenczi, Sándor. 1913. "Stages in the Development of the Sense of Reality." In Contributions to Psychoanalysis, 213-39. New York: Basic Books, 1950.

Freud, Sigmund. (1913) 1955. Totem and Taboo: Some Points of Agreement between the Mental Lives of Savages and Neurotics. In The Standard Edition of the Complete Psychological Works of Sigmund Freud. Vol. XIII, 1913-1914: Totem and Taboo and Other Works, edited by J. Strachey, 1-161. London: The Hogarth Press.

— . (1916-17) 1963. "Introductory Lectures on Psycho-Analysis." In The Standard Edition of the Complete Psychological Works of Sigmund Freud, Volume XVI, 1916-1917: Introductory Lectures on Psycho-Analysis, Part III, edited by J. Strachey. London: The Hogarth Press.

Gilman, Sander L. 1985. Difference and Pathology: Stereotypes of Sexuality, Race, and Madness. Ithaca: Cornell University Press.

Jacobs, Margaret D. 2009. White Mother to a Dark Race: Settler Colonialism, Maternalism, and the Removal of Indigenous Children in the American West and Australia, 1880-1940. Lincoln: University of Nebraska Press.

Jarrett, Simon. 2016. “The Road to Dr. Down's Idiot Asylum: The Creation of the Idea of Intellectual Disability, 1700-1867.” PhD Dissertation. Birkbeck, University of London. 
Jones, Ernest. 1920. “A Linguistic Factor in English Characterology." International Journal of Psychoanalysis 1: 256-61.

_ 1925. "Mother-Right and the Sexual Ignorance of Savages." International Journal of Psychoanalysis 6: 109-30.

Khanna, Ranjana. 2003. Dark Continents: Psychoanalysis and Colonialism. Durham, NC: Duke University Press.

Kuper, Adam. 1988. The Invention of Primitive Society: Transformations of an Illusion. London: Routledge.

Laplanche, Jean, and Jean-Bertrand Pontalis. 1973. The Language of Psycho-Analysis. London: Hogarth Press.

Linstrum, Erik. 2016. Ruling Minds: Psychology in the British Empire. Cambridge, MA: Harvard University Press.

Morris-Reich, Amos. 2006. "Race, Ideas, and Ideals: A Comparison of Franz Boas and Hans F.K. Günther.” History of European Ideas 32: 313-32.

Nandy, Ashis. 1984. "Reconstructing Childhood: A Critique of the Ideology of Adulthood." Alternatives: Global, Local, Political 10, no. 3: 359-75.

- 1995. The Savage Freud and Other Essays on Possible and Retrievable Selves. Oxford: Oxford University Press.

Pick, Daniel. 1989. Faces of Degeneration: A European Disorder, c. 1848-c. 1918. Cambridge: Cambridge University Press.

Qvortrup, Jens 1994. “Childhood Matters: An Introduction.” In Childhood Matters: Social Theory, Practice, and Politics, edited by Jens Qvortrup, Marjatta Bardy, Giovanni Sgritta, and Helmut Wintersberger, 1-12. Aldershot: Averbury.

Róheim, Géza. 1932. "Psycho-Analysis of Primitive Cultural Types." International Journal of Psychoanalysis 13: 1-221.

- 1934a. “The Evolution of Culture." International Journal of Psychoanalysis 15: $387-418$.

. 1934b. The Riddle of the Sphinx: Or Human Origins. Translated by R. MoneyKyrle. London: Hogarth Press.

Said, Edward W. 2004. Freud and the Non-European. London: Verso.

Seshadri-Crooks, Kalpana. 1994. “The Primitive as Analyst: Postcolonial Feminism's Access to Psychoanalysis." Cultural Critique 28 (Autumn): 175-218.

Smadja, Eric. 2011. "The Oedipus Complex, Crystallizer of the Debate between Psychoanalysis and Anthropology" International Journal of Psychoanalysis 92: 9851007.

Stoler, Ann Laura. 1995. Race and the Education of Desire: Foucault's History of Sexuality and the Colonial Order of Things. Durham: Duke University Press.

Trautmann, Thomas R. 1992. “The Revolution in Ethnological Time." Man 27, no. 2: 379-97. 



\title{
Géza Róheim: \\ Alienness as a Source of Political Attitude
}

\author{
György Péter Hárs
}

Géza Róheim was an unusual man. Both his life and his work are full of antinomies, complications, and puzzles. He was born in Budapest in 1891 and died in New York in 1953. My study explores the personality of Géza Róheim in connection with his political views and his identity as a scientist. First, I introduce the young Róheim and his attitude to sports and to his family. These aspects were entangled and were characterized by intense rivalry. As we will see, the tragedy of Róheim and his evolution are rooted in his youth: his early rivalries in sports as well as within his family shifted to his conflict with the state policies, and later to the rules governing the scientific world of Hungary. This was the intellectual path that led Róheim to write his study on patriotism in 1950. Here, he first evokes Sándor Petöfi ${ }^{1}$ and then quotes Lajos Nagy ${ }^{2}$ and János Arany. ${ }^{3}$ The conclusion is very clear: patriotism is a mental state; it is not nationalism but rather a feeling of belonging to a tradition that encompasses both good and bad characteristics.

${ }^{1}$ Sándor Petőfi (1823-1849) was a Hungarian poet who died during the 1848 Hungarian revolution and war of independence.

2 Lajos Nagy (1883-1954) was a Hungarian writer, publicist, and member of the Stekelian Független Orvosanalitikusok Egyesülete (Association of Independent Medical Analysts) founded in 1925 by Sándor Feldmann.

3 János Arany (1817-1882) was a Hungarian poet, friend of Petőfi, member and secretary of the Hungarian Academy of Sciences, and was a forerunner of modern poetry in Hungary. 
After tracing the development of his seminal study, I will turn to events that led Róheim to leave his homeland, including the changing political, scientific, and familial circumstances. I revisit Petőfi's poem and Lajos Nagy's sociography to assert that living in another country deepens the contrast of patriotism and otherness. This is the context that formed Géza Róheim's thinking and his life as a pioneer of psychoanalytical anthropology, intercultural psychoanalysis, and dream analysis.

\section{Fair Play}

In 1905, 1906, 1907, and 1908, the newspapers Nemzeti Sport (National Sport), Sport-Világ (Sport-World), and Pesti Hírlap (Pest Newspaper) all reported on a young man named Géza Róheim. In 1905, he won the men's singles table tennis in Siófok, and he got into the final of the table tennis championship, which he won as well. He also won the men's doubles final and the men's handicap cup too. In 1906, Róheim made it to the final of the Hungarian Table Tennis Championship-the prize was offered by Leontine Róheim, Géza Róheim's mother. ${ }^{4}$ After this event in Siófok, he won the silver medal in three types of lawn tennis. In 1907, the lawn tennis championship was held in Siófok again and the daily Pesti Hírlap reported that, "Géza Róheim won the championship. We reckon that we will see the name of this young player at national and international tournaments often" (Lawn-tennis 1907, 19). He won the men's championship, the men's single handicap cup, the men's doubles handicap cup, mixed doubles, and the mixed doubles handicap-practically every event. A year later, at the competition of the National Fencing Club in 1908, he won first prize in two events, and in addition to these three sports, he also regularly participated in competitive boxing matches and canoed (Javorniczky 1990).

We can draw some conclusions from Róheim's career in sports. First, sports can play an eminent role in one's life, behavior, and attitudes. One can learn to understand and respect the thought and behavior of an opponent or even a partner, and also learns how to win and lose. Therefore, one can acutely experience subordination and triumph. But Róheim's sports career also provides us with insight into the relationship he had with this mother. The incident at the tennis championship in Siófok provides us with a glimpse of their

\footnotetext{
${ }^{4}$ For more information see Hárs 2009b, 47-48.
} 
relationship, which culminated in Róheim's wedding. In fact, after he settled in the United States, he never wrote letters to his mother. His participation in sports also shows us Róheim's attitude towards a strange new world and towards Hungarian mythology, clarifying his strong Hungarian and ethnologist identity. Another question is the possible connection of family relations to his political identity and his permanent alienness. Can living as an alien be considered an identity? Is it a political identity or a political attitude as well?

\section{A Poem and a Spiritual-Intellectual Trip through a Life in Space and Time}

In 1842 a young Hungarian poet named Sándor Petőfi wrote a poem about his homeland entitled "Hazámban" (In my homeland). ${ }^{5}$ More than a century later, Hungarian scientist Géza Róheim, who had lived in the United States for fourteen years, began one of his studies (Róheim 1950) with this poem. A Hungarian reader would notice that he quoted only the first and the last verses of the poem; there are six stanzas missing between them (see Appendix).

Reading the study, it seems to me that it is a self-confession in which the missing stanzas are, so to say, repressed. It is as if those verses had no connection with the content of Róheim's writing. What are they about anyway? Primarily, they tell the story of a psychic journey from cradle to coffin; from homeland to homeland; from mother to mother; from motherland to motherland. We cannot say fatherland here, not only because there is nothing about the father in the poem, but because the term does not fit the context. Although they are synonyms, the words "homeland," "motherland," and "fatherland" have different senses and significance. Homeland relates more to the concepts of cultural geography, ethnic groups, and national identity. Motherland relates to the place of birth, the home of ancestors, or to an emigrant's place of origin, whereas fatherland means the nation of one's father, and the word is inflected with a nationalist tone.

The two cited stanzas describe and address the motherland. The mother herself is not present. However, there are allusions to her in the last stanza through the "cradle" and "mother's milk." Both stanzas speak to the mother-

\footnotetext{
${ }^{5}$ In Hungarian, see http://magyar-irodalom.elte.hu/sulinet/igyjo/setup/portrek/ petofi/hazamban.htm
} 
land: "Doest thou still recognize me / And really know thy son?" and "The day will shine again and make me thine / Thy child again, beloved country mine." The translation is not precise. In the Hungarian text, there is a question in the middle of the last line of the first stanza that is missing in the English. The same line closes by expressing an imperative or desire with an exclamation mark at the end. Word-for-word it sounds like this, "Do you still know me? oh get to know your son!" At the end of the last stanza, there is an exclamation mark again, but it is merely an exclamation, "my sweet beautiful home!" Hence, the opening and the closing stanzas express emotion and passion deriving from a strong desire manifested in an imperative and a strong feeling of beatitude and satisfaction. We can state this all the more, as in the text of the poem there is only one other sentence-ending punctuation mark: another exclamation mark in the last line of the sixth stanza. It points to a desire in the past, unlike the present tense of the first and last stanzas: "I would rather have drunk death!" There is sophisticated play with tenses; in contrast with the pictures of birth and infancy, the lyrical ego desired death in his sorrowful past and recounts his previously happy past, which he yearns for in the happy present.

From the second stanza to the fifth stanza, the farewell and the road away are described. The seventh stanza is permeated with the pleasure of arriving home. Thus, the question "Do you still know me?" and the imperative "oh get to know your son!" receive an answer in a self-introduction in the intermediate stanzas. The trek proceeds from cradle to coffin and back.

There is poetic playfulness in the poem, not only in and with time, but in and with place. With the sky, the earth, and the mirrored earth in the sky there is a "sweet phantom bearing mirage." The earth purely possesses punitive and obstructive characteristics-like the Freudian superego it is "bumpy," "rough," like a "desert," and the drink it gives is deathly "mugwort." Travelling is the way of life. The sky is peace, rest, and kindness-as it can be observed from below-and it is the place where the earth is mirrored in a "sweet phantom-bearing mirage," in a wish, like the Freudian ego-ideal. In its mirror, the earth changes to a "plain ornament with sheaves of gold," it is the world of "breezes" and air, and the mugwort turns into "mother's milk," the coffin into cradle. This is the world of childhood.

This duplicated play with place and time is where the identification of the mother and the motherland with one another takes place. For the father, there

${ }^{6}$ Unfortunately, Róheim did not provide the source of this translation. 
is no place. Although Róheim himself does not discuss parts of the poem nor quotes from it, the figure of the father appears in his study later. I argue that the significance of this poem to Róheim, the significance of the missing stanzas, as well as the choice of this specific poem are connected with his own family relationships. He even repeats the spiritual-intellectual journey in the structure of his study.

The identification of mother and motherland is where Róheim (1950) refers to the poem nearly at the start of his study, after wandering through time and place. He concludes, "1) The mother country is the mother 2) It is a mother seen through the mirage of fantasy 3 ) There is a desire to return, a nostalgia, a regressive trend" (6-7). While he gets there, he makes a virtual tour starting from the world of animals in general and then moving on to primates (with chimpanzees and gibbons as examples), continuing his way through the beliefs and myths of tribes (the Kaingang people, ${ }^{7}$ the kurra [bandicoot] clan, ${ }^{8}$ the Yakuts, ${ }^{9}$ and the Voguls ${ }^{10}$ ). At this point of his journey, Róheim intervenes to make two important statements deriving from his data. The first is that, "Mother goddesses or goddesses of the earth exist independently of goddesses of agriculture" (Róheim 1953, 4-5). The second one is that, "The earth goddess or the totem caves from which all spirit children emanate are the core of all patriotism” (Róheim 1953, 5). He then moves on to the ancient Athenians, citing Euripides, and concludes that "it is the mother whom the child can love, because the memory of the primal scene (Zeus or Poseidon or Pallas and Athena) and the memories of his own pre-Oedipal or Oedipal aggression are repressed-this is the basic element of patriotism. These unconscious trends and defense mechanisms are eternalthe Virgin Mary is the Patrona Hungariae, and probably she is the patron of many other Christian countries too" (Róheim 1953, 7).

This is the point where he alludes to Petöfi. From here, from "home"he moves again to "savages," but to a familiar place for him: the aboriginal tribes of Australia (the Matuntara and Aranda people, the Murngin tribe, and the Wawilak clan). Knowing his relationship with Australians and the time he spent there, he is at ease there too. He stops to formulate two statements

\footnotetext{
7 A native American ethnic group living in Brazil.

${ }^{8}$ One of the Jhangi clans; the former residents of Jhang-multan spread throughout India, Pakistan, and Afghanistan.

9 A Turkic people living in Siberia.

10 Voguls or Mansi are indigenous peoples living in Siberia.
} 
again regarding eating and feeding: "the introject aspect of one's own country is made very clear by the significance of national food. . . . If we look at nations or groups from this point of view, the first thing that strikes us is the importance of national food" (Róheim 1953, 9).

From here, he travels far in both space and time to "Old England." England appears almost like America, the place he lived at the time he wrote the study. From there, he looked back to his motherland Hungary, to the table of the Csengei family. Indeed, he has arrived home, let us not forget, through the idea of food. While speaking about Hungarians, he again evokes non-industrial peoples ("Amazulu,"11 "Hottentotts,"12 "Wagogo,"13 people of Gippsland, ${ }^{14}$ and Indians) parallel with Hungarians.

From the text of Róheim and the examples he uses, it is clear that he is making an inference between eating customs and political attitudes; political attitudes may be partly determined by food and food may be partly determined by political attitudes.

This hypothesis could be proposed in relation to the question Róheim's nephew, Charles Rohonyi, asks about Róheim's emigration: "is it possible that only some peculiar Hungarian food made him homesick?” (Rohonyi 1992, 133).

\section{Political Attitude}

I want to explain what I mean by political attitude, which does not belong exclusively to a party or a political idea. For me, political attitude consists of identity and behavior, so an apolitical attitude is also a political attitude. Róheim's political attitude was formed in the Róheim villa. Róheim was an alien in his own family. He subsequently became an alien among ethnologists and psychoanalysts. He was also an alien among the indigenous peoplesthose he called "savages" - he studied. In the 1930s, he was an alien in his

11 The Amazulu (Zulu) are a Bantu ethnic group of Southern Africa and the largest ethnic group in South Africa.

12 Nomadic pastoral people called Khoikhoi living in South-West Africa.

13 The Gogo (singular: mgogo, plural: Wagogo) are a Bantu ethnic and linguistic group based in the Dodoma Region of central Tanzania.

14 Gippsland is a region that occupies much of the south-eastern part of Victoria, Australia, originally inhabited by indigenous Australians of the Gunai nation and parts of the Bunurong nation. 
Hungarian homeland, and then he became an alien in the United States, his adopted home. I suppose that an alien identity and political attitude hang together. This may be at least one of the reasons that Róheim became a pioneer of inter-, multi-, and transcultural psychology and psychiatry.

Székács speaks about Róheim's "naive attitude" regarding politics (Javorniczky, 1990), but I think his writings have political significance, even those he produced in the first phase of his career, especially in his work on Hungarian Folk-Beliefs and Customs (Róheim, 1925). These writings turn against "the conception of Hungarianness decontaminated from Jewish, German, or Slavonic origins" represented by the "political side of 'Hungarian-Hungarians, standing on 'racial' grounds," as Szász (1928) writes.

Róheim's first political views were published in his book about aboriginal peoples of Australia. He wrote:

Paranoid patients often make certain social or political groups responsible for every problem from which they suffer. Such "schemers" can be Jews, freemasons, socialists, or the Jesuits, international clericalism, the Ku Klux Klan, etc. But if we observe more thoroughly the work of "normal" politicians, we find there (if in less radical form) essentially the same tendency. For the opposition, the governing party is responsible for the fate of the country. It seems that we need a scapegoat for social coexistence; one that is responsible for all troubles, and one we endow with a supernatural power due to the father-ideal of childhood. Only the fact that it is more difficult to recognize relationships-because of their greater sublimation, desexualization-differentiates the mentality of politics from psychosis. (Róheim 1932, 259)

\section{The Family}

Let us start with Róheim’s family. His disciple, psychoanalyst István Székács remembers, "Géza Róheim was born into a bourgeois family. The Róheim villa was the place where István Tisza ${ }^{15}$ was murdered, because he rented the

15 István Tisza (Count István Tisza de Borosjenő et Szeged, 1861-1918) was a Hungarian politician, prime minister, political scientist, and member of the Hungarian Academy of Sciences. The prominent event in his life was Austria-Hungary's entry into World War I, when he was prime minister for the second time. He was later 
ground floor of the villa. My analysis happened also in the villa. Róheim, as expected, lived in the garret" (Javorniczky 1990). Róheim's career as a scientist and then a psychoanalyst was unique in this world of agriculture, business, and the Budapest upper crust. As his nephew, Charles Rohonyi wrote, "his father was an uncolored, trivial man, but his mother was a strong woman with a dominant nature and social success" $(1992,133)$. Ferenczi mentioned in one of his letters to Jones that "his rather well-off father is very stingy" (Ferenczi and Jones 2013, 115). As Rohonyi remembers, "his father, his mother, his cousins, and the circle of friends of the family spoke about him resignedly, 'poor Géza' is not totally normal; he deals with such stupidities, and the 'atrocities' are that he does not want to farm" $(1992,131)$.

When Róheim decided to marry, his family relationships deteriorated further. As Székács recalls, "his wife was lovely, very charming, warm-hearted, and very pretty, and as far as I know, a second-rate comedian" (Javorniczky 1990). Rohonyi writes that "the family fought hard to stop [Róheim's wedding], and at that time, aunt Leontine [Róheim's mother] declared that Ilonka [Róheim's wife] must not live in her house. After his mother's ultimatum, Géza married Ilonka and they moved to Nyúl street in Buda. There they lived very modestly; he taught English and occasionally worked as a psychoanalyst" $(1992,131)$. At another point, Rohonyi mentioned that "[Géza] totally breaks away from his mother, never writes letters to her from America, not even after the war! Ilonka writes to her now and then" $(1992,133)$.

I think this brief family portrait explains why Róheim chose exactly these segments of the poem as the frame of his study, and his allusion to this particular poem also makes the absence of a father clear.

\section{The Alien in the United States}

In the United States, Róheim was an alien in the psychoanalytical society because he was an orthodox Freudian. By that time, new trends of analysis were popular both in theory and practice. However, Róheim rediscovered his Hungarian and Jewish identity precisely in the United States and in that professional milieu.

assassinated during the Chrysanthemum Revolution on October 31, 1918. Tisza supported the Dual Monarchy of Austria-Hungary and was a representative of the liberal-conservative consensus. 
Few people put so much effort into making Hungarian folklore and Hungarian folk culture more popular and reputable as Róheim did. He also wrote many articles on racism, patriotism, and nationalism and gave lectures on these topics. He gave one of his first papers on the subject, "Race-psychology and Evolution" while still in Hungary in 1928 (Róheim 1928). But he wrote a unique study in 1950 (mentioned in the second part of this essay) about nationalism, patriotism, and about his homeland, Hungary, based on poems by two Hungarian poets. This study is rather surprising because Róheim never went back home to Hungary after moving to the United States, and, as mentioned earlier, he never wrote any letters to his parents. This has particular significance when someone reads the study in light of the aforementioned biographical information. Moreover, the article starts with a poem in Hungarian and its title also contains the precise title of that poem in Hungarian. The study was published in American Imago (Róheim 1950) three years before Róheim's death, and was entitled, "The Psychology of Patriotism: Hazámban" (In my country).

Here, I will discuss only three questions relating to the analysis of the theme specified in the title of this study from the perspective of Hungarian culture. These are: national food, Hungarian "virtus," and the trauma of the Treaty of Trianon. About the word virtue, Róheim clarified that "it does not mean virtue in the moral sense" (Róheim 1950, 10). In the "Latin original, Virtus is the personification of military prowess," and in Hungarian, the sense of the word is nearly the same.

Róheim begins his study with the definition of nationalism. The traditional interpretation of this concept and the development of the idea comes from history. Róheim quotes Kohn, whose opinion is that, "nationalism as we understand it is not older than the second half of the eighteenth century. Its first great manifestation was the French revolution which gave the new movement its first dynamic force. ... For its composite texture used in its growth some of the oldest and most primitive feelings of man found throughout history as important factors in the formation of social groups." (Kohn 1944, quoted in Roheim 1950, 1) But Róheim finds this thought "very surprising" because he is thinking about the question in a different way-from the perspective of an anthropologist.

He first refers to biological facts. The colonies of animals "rarely if ever leave their territory." He mentions that "chimpanzees are home-loving beings and do not forsake the place where they were born except under special circumstances. Gibbons are intolerant of other gibbons invading their ter- 
ritory" (Róheim 1950, 4). After describing a few customs and myths of different tribes and differentiating mother goddesses or the goddesses of the earth from goddesses of agriculture, he comes to the discussion of mother, father, and territory. Because the motherly "earth goddess or the totem caves" are "the core of all patriotism," he begins with the role of the mother. The psychoanalytical interpretation of the role of the mother in forming the idea of patriotism works with dualities or oppositions. Róheim speaks about introjection (milk) and projection (faeces), that is introjecting the good and projecting the bad. Inside (the maternal cave) is safe and outside (the world where demons live) is uncertain and full of dangers; "the nation or the ingroup and the outgroup are in a sense the repetition of the Ego based on introjection ... and projection. ... In a primitive tribe initiation, belonging to a tribe reveals much of the unconscious content of the idea of the nation" (Róheim 1950, 7).

The next pages of the article deal with fathers and sons, food taboos, and ritual eating customs. Róheim projected the dynamic and dilemma in the Oedipus conflict to the experience of the primary scene, or the desire to be identified with the father and to possess the mother. First, Róheim interprets the ceremony of an Australian tribe concerning ritual eating and steaming. $\mathrm{He}$ concludes the following:

... elements leave the body (the alien is a demon) and the sacred food (parents) form an introject. The introject aspect of one's own country is made very clear by the significance of national food. The ego ideal is based on an introjection of the parental imago and the endogenous sources of gratification of the body, that is, it signifies the introjected father and phallic magic or the introjected mother and oral magic, etc. It has an introjecting (object) and an ejecting (narcissism) component. If we look at nations or groups from this point of view, the first thing that strikes us is the importance of national food. (Róheim 1950, 9)

After quoting an English verse about roast beef, he describes Hungarian eating customs, starting with paprika (bell pepper is also widely used in powder form). "The history of the national food-symbol of Hungary, the famous paprika, is an interesting example of the psychological significance of national food. ... Gradually [paprika] became more than popular, it became a symbol of being a Hungarian. To reject it means to reject Hungary, to like it means to re-identify oneself with the group at every meal" (Róheim 1950, 10). 
To prove his point, he quotes from a Hungarian author who was analyzed: "as far as I know this is the only book in which a European (or American) village is looked at from a psychoanalytic point of view." (Róheim 1950, 11).

We are familiar with the eating customs of the Csengei family. We are informed that "pater familias" Csengei puts green bell pepper slices in his soup. The paprika is very hot and eating it needs training. Csengei likes to eat and drink only what is hot or hard or sour. Before tasting, he puts a lot of salt, paprika, and pepper in everything. He likes onion and garlic as well. For him, things in nutrition are divided into two categories: eatable and not eatable. Milk, cakes, jam, most of the vegetables and fruits, etc., are not eatable-they are for women and infants. "Hot paprika is virtus" (Nagy 1937, 45); quoted in Róheim 1950, 11). But Róheim adds to this:

to accept every challenge and to challenge everybody to a duel at the slightest provocation (or without provocation) is real Hungarian virtus, for the middle classes that is. The corresponding phenomenon in the life of the peasant class would be drinking and the habitual Sunday knife-duels in the village inn. Drinking a lot of wine without showing the signs of intoxication is also virtus but drinking a corresponding quantity of beer is not so good because beer is a German drink. Brandy is for the Slovaks, only wine is for the Hungarians. (Róheim 1950, 11)

"Uncle Csengei likes only food that nearly hurts." Therefore, as Róheim quotes, "there is no doubt that it has psychological significance" (Nagy 1937, 45); quoted in Róheim 1950, 12). Before analyzing this question, Róheim wrote a short remark that is not explained in the study-we can only try to interpret it in the context of food. "According to Hungarian tradition, the nation itself is based on a blood covenant, a pact in which the chiefs of the seven tribes pour their blood into the same vessel" (Róheim 1950,13). This has double significance. First, according to some authorities, although Róheim does not refer to it, the tribes' chiefs drank mixed blood, so it was an action of introjection. The other cause of inserting this note may be Róheim's own patriotism and his effort to garner respect for Hungarians. This sentence is the bridge to his discussion of the relationship between eating and drinking and identity. After enumerating several examples of eating and drinking ceremonies, he turns to customs and beliefs of various tribes that all refer to the introjection and identification with things eaten, be it either "the dried skin of the leopard, the lion, 
and the snake" or the leopard's blood and heart, or a dead man's fat. In each case, people believed that if they ate the blood or the body of something or someone they would assume their powers. Róheim concludes:

evidently, Csengei is eating only his ego-ideal, something that is strictly male and that will keep and enhance his virility. Tough meat is male, soft meat female. Hot food is male, the opposite female. . . However, Csengei's diet is regulated not merely by the fact that he is a man and what he introjects must be male but also that he is a Hungarian and what he eats must be Hungarian. ... If we take a glance at the self-portrait of the Hungarian, we soon find that the two ideas (being a Hungarian and being a man) are really identical. (Róheim 1950, 13-14)

At this point, Róheim refers to the poem of János Arany in which he "has put down his version of what he regards as a typical Hungarian in his poem 'Magyar Misi' (Michael the Hungarian)" (Róheim 1950, 14). Magyar Misi is a peasant who has many lovers and a devil-may-care attitude. He devours women one after another. He pays for his wine if he has money, but if he does not, he threatens the innkeeper with a beating. He shares his wine with anybody, but if someone does not drink with him, "that man is lucky if he escapes alive" (Róheim 1950, 14). He is clever, but does not want to learn. He does not like the army, but he is the best soldier in it. Consequently, he thinks he embodies the Hungarian virtus, the male ideal of virility.

"How far this national imagery corresponds to the truth is questionable," says Róheim. And he follows:

the point is that all nations believe that they have the privilege of virility. ... Eating national food means introjecting the father, and belonging to a nation means the successful mastery of the Oedipus complex. For the member of a group (nation) belonging to the group means that he has identified himself with his own father, and that he has a right to the land, the symbolic mother. The parental images are introjected, they have become a part of his ego-ideal, something that is a powerful synthesis of object love and narcissism. To be separated from the nation is a castration threat and means being guilty of Oedipal desires. (Róheim 1950, 14-15)

One of the variants of patriotism or nationalism is irredentism. According to Róheim, this formation is related to the problem of castration. He 
refers to Hungary again to explain this phenomenon. The Treaty of Trianon was a trauma for many Hungarians, as the country lost two-thirds of its territory and Transylvania was ceded to Romania. Róheim quotes a song about Királyhágó (King's pass, today, Bucea in Romania), and interprets both its conscious and unconscious meaning. Consciously, it is about a pass, the frontier between Hungary and Transylvania, and a so-called csákó (a Hungarian paramilitary cap). In the song, the csákó is lost, just as parts of Hungarian territory are lost. If we can find our csákó again, we can "drive the Romanians out of Transylvania" (Róheim 1950, 16). But there is an unconscious meaning of the text as well. While Királyhágó means the place where the King passes, the word "hágni" also means to have intercourse. "The song then means castration anxiety (the lost Hussar's cap). Mastered, the penis will come back and the whole mother will be in his possession once more" (Róheim 1950, 17).

At the end of this article, Róheim sums up the theme: "the unconscious contents we have discussed in this paper are summarized in the integration of the group, in the psychological frontiers of in-group versus out-group" (Róheim 1950, 17). However, there is another message in the text for anthropologists, "but anthropologists themselves are part and parcel of trends now manifesting themselves in groups and they tend to overemphasize this integrative element. They see only the nation, the mankind, and the individuals are forgotten" (Róheim 1950, 17).

Róheim knew that the individual is as important as mankind and the nation, and in some cases more complex. It may be complicated if the individual does not live in her or his own country or if her or his own country regards and treats them as an alien, or if she or he is simultaneously a member of an in-group and out-group having double or multiple identity-or perhaps she or he stays on the "frontier," even if that frontier is unknown to herself or himself.

Regarding his moving to the United States, Róheim's nephew Charles Rohonyi states that the farewell was easy. "It isn't true that he was so homesick. Even if he had been, it went unnoticed by the Róheim villa, or by his mother. Was he drawn home by some Hungarian food perhaps? It is sure that when he received his passport and nationality from the United States ... he left the country with a light heart" (Rohonyi 1992, 133). However, Róheim's letter to Károly Marót ${ }^{16}$ in 1939 seems to contradict this opinion. "I can only

16 Károly Marót (1885-1963) was a classical philologist, university professor, and member of the Hungarian Academy of Sciences. 
say that all this was such a great convulsion for me ... to migrate is a trying thing. It is not the outer circumstances that are so crucial; the problem is with the emotions. My parents are at home and goodness only knows if I will ever see them" (Róheim 1992, 120). It is somewhat surprising that Róheim misses his parents given that he never returned home and never corresponded with them. Maybe Rohonyi is right after all? But other sources also confirm "he was not really rich or really blissful in New York even in the last decade of his life...." (Voigt 2008, 95).

His wife Ilonka died before him. She was the organizer of the expeditions. Ilonka always travelled ahead, so by the time Róheim arrived, his writing table, paper, and ink were in place, exactly as he needed them (Javorniczky 1990). Shortly before his own death, Róheim said to his visitors in the hospital, "I will die and that's right because Ilonka went ahead and organized what I am supposed to do in heaven" (Javorniczky 1990). For his funeral ceremony, he wished his coffin to be wrapped in a Hungarian flag, he asked for a Jewish rabbi, and a speech to be spoken in Hungarian. He got everything. As Raphael Patai remembers, "when he died, I buried him because he asked in his last will that Hungarian should be spoken at his burial. I was the only anthropologist whom he knew and with whom he spoke Hungarian" (Patai 1997, 52) ${ }^{17}$ Although Patai gave his speech in English, he said the last sentence in Hungarian: "Drága Géza bátyám, Isten veled!" (quoted in Voigt 2008, 95). That is, "My dear brother Géza, God be with you!"

${ }^{17}$ Raphael Patai (1910-1996) was born Ervin György Patai. He was a HungarianJewish ethnographer, historian, Orientalist, and anthropologist also interested in psychoanalysis. He was a friend of Róheim. 


\section{Appendix: The stanzas of Petőfi's poem "Hazámban" quoted by Róheim:}

Thou plain ornament with sheaves of gold covered with a sweet phantom bearing mirage

Doest thou still recognize me

And really know thy son?

[...]

Where I once in my cradle's lap so soft

Tasted the sweetness of my mother's milk

The day will shine again and make me thine

Thy child again, my beloved country.

\section{REFERENCES}

Bryan, Douglas. 1928. "British Psycho-Analytical Society. First Quarter, 1928." Bulletin of the International Psycho-Analytic Association 9: 385-86.

Ferenczi, Sándor, and Ernest Jones. 2013. Letters 1911-1933. London: Karnac Books.

Hárs, György Péter. 2007. “Túl a pszichoanalízisen. Székács-Schönberger István pályaképe" [Beyond psychoanalysis: The career prospects of István Székács-Schönberger]. In Egy zsidó polgár gyermekkora [The childhood of a Jewish citizen], edited by István Székács-Schönberger, 167-90. Budapest: Múlt és Jövő Könyvkiadó.

— . 2009a. “Drága Géza bátyám, Isten hozott!” [“Welcome, dear uncle Géza!”] In Ádám álma [Adam’s dream], edited by Péter Hárs György, 267-300. Budapest: Múlt és Jövő Könyvkiadó.

—. 2009b. "A “vörös Róheim”" [The "red Róheim”]. Thalassa 20, no. 4: 45-74.

Javorniczky, István. 1990. Interview with István Székács-Schönberger. Unpublished manuscript.

Kohn, Hans. 1944. The Idea of Nationalism. New York: Macmillan.

"Lawn-tennis." 1907. Pesti Hírlap 187 (August 7): 18-19.

Nagy, Lajos. 1937. A falu álarca [The mask of the village]. Budapest: Nyugat Kiadó és Irodalmi.

Patai, Rafael. 1997. "Két világ határán, két világ szélén” [At the border of two worlds, at the edge of two worlds]. Múlt és Jövő 2: 44-52.

Róheim, Géza. (1925) 1990. Magyar néphit és népszokások [Hungarian folkways and popular customs]. Budapest: Athenaeum.

. 1928. "Race-Psychology and Evolution." Bulletin of the International PsychoAnalytic Association 9: 387-89. 
. (1932) 1992. A csurunga népe [The people of Churunga]. Budapest: Athenaeum. . 1950. “The Psychology of Patriotism: Hazámban (In My Country)." American Imago 7: 3-19.

Rohonyi, Charles. 1992. "Levele (1975) Verebélyi Kincsőhöz” [Letter (1975) to Kincső Verebélyi]. Thalassa 3, no. 2: 131-34.

Szász, Zoltán. 1928. "Magyar néphit és népszokások. Dr. Róheim Géza könyve" [Hungarian folkways and popular customs: The book of Dr. Géza Róheim]. Nyugat 20. http://epa.oszk.hu/00000/00022/nyugat.htm.

Székács-Schönberger, István. 2007. Egy zsidó polgár gyermekkora [The childhood of a Jewish citizen]. Budapest: Múlt és Jövő Könyvkiadó.

Verebélyi, Kincső. 1977. Róheim Géza. Budapest: Néprajzi Múzeum.

— 1990. Róheim Géza. Budapest: Akadémiai Kiadó.

Voigt, Vilmos. 2008. "Raphael Patai öröksége" [The heritage of Raphael Patai]. Múlt és Jövő 2-3: 89-95. 
PART THREE

Psychoanalysis and Psy-Knowledge in Soft and Hard Dictatorships 



\title{
Psychoanalysis in Troubled Times: Conformism or Resistance?
}

\author{
Stephen Frosh
}

\section{Preface}

If psychoanalysis is at least in part a "Jewish science," as I think it is (Frosh 2005), then there are plenty of reasons to be a little anxious about it in Hungary, whatever celebrations we might have of Ferenczi, Bálint, or Róheim. The magnitude of the devastation of Hungary's Jewish population in 1944 (400,000 of them were killed in Nazi death camps, rounded up under Eichmann's guidance with the aid of the Hungarian authorities) has rarely been fully acknowledged in Hungary itself, and the continuation, perhaps even the rise, of anti-Semitism in contemporary Hungary is well documented (e.g., Kovács 2012). Whether this should be understood as an element in a generally authoritarian political context marked by the dominance of the nationalistic ultra-right - the hardline response to the 2015 refugee crisis being just one instance of this-or whether it is more specific, directed precisely at Jews and the idea of the Jew, is something that requires more detailed and careful analysis than I am capable of giving. But it hangs as a black cloud over my thinking and maybe over that of others. Psychoanalysis in Europe had Jewish origins and was dominated by Jews until the coming of the Nazis. Then it was destroyed, with various degrees of heroic resistance and culpable complicity, and neither the international psychoanalytic movement nor many of the countries involved have fully dealt with the legacy of this destruction (Frosh 2012). This is a legacy of a parricide, perhaps, or an atavism, or a straightforward act of hatred followed by denial. It keeps cropping up too, for example in enactments in psychoanalytic congresses, where anti-Semitism seems 
somehow to appear in the complex mix of attitudes and affiliations that psychoanalytic history inspires (Ehrich et al. 2009).

I will leave this distasteful topic shortly but also abstract it into some thinking about psychoanalysis' institutional responses to some of the pressures it has faced in other authoritarian societies. Without documenting in detail the response of Hungarian psychoanalysts to political authoritarianism, it is clear that the Hungarian Psychoanalytical Society, after the bright start led by Ferenczi, went through some very bad times under the fascist and communist regimes. It is also notable that psychoanalysis was subjected to antiSemitism from early on. Here is Ferenczi, writing to Freud in 1919 after the collapse of the brief Soviet Republic:

After the unbearable "Red terror," which lay heavy on one's spirit like a nightmare, we now have the White one ... the ruthless clerical/antiSemitic spirit seems to have eked out a victory ... we Hungarian Jews are now facing a period of brutal persecution of Jews. ... It is naturally the best thing for psychoanalysis to continue working in complete withdrawal and without noise. (Mészáros 2012, 85)

This particular withdrawal was forced upon the analysts by anti-Semitism; as will be seen, other occasions of political withdrawal have had other determinants. There were various immediate effects of the end of the Soviet experiment, including Ferenczi's dismissal from his university appointment (he had been the first Professor of Psychoanalysis in a university department), a wave of emigration of Jews and intellectuals, including several psychoanalysts (for instance, Melanie Klein and Sándor Radó), and the lost opportunity for Budapest to become the center of European psychoanalysis. After 1938 and the adoption of more stringent anti-Jewish laws by the right-wing Hungarian government, many more Jewish analysts left; those that remained struggled terribly during the war years, and several were killed. Judit Mészáros, seeing the losses to psychoanalysis as an indirect result of anti-Semitism rather than an attack on psychoanalysis itself (which was more the case under communism), and praising the action of the non-Jewish leaders of the residual psychoanalytic movement, comments:

The antipsychoanalysis ideology of Nazism-which declared psychoanalysis to be a Jewish intellectual product and launched a propaganda campaign against it that distorted its principles and created an atmo- 
sphere of utter contempt-had essentially not managed to seep into Hungary during the 1930s and 1940s. Nevertheless, indirectly, both the White Terror under the Horthy regime and the anti-Jewish laws as of 1938 as well as the destruction wrought by Hungarian and German Nazis - through the persecuted Jewry-led to massive losses in Hungarian psychoanalysis. (Mészáros 2012, 102)

Although she is careful to document the efforts to help Hungarian Jewish analysts, Mészáros also notes the damage that was done to the Hungarian society and the ambiguities of its continuing official survival during the war. She notes:

In 1939 before World War II broke out, the Hungarian Society included 28 members and three associated members. Five of them emigrated in the years to follow: Róbert Bak, Sándor Feldmann, Fanny Hann Kende, Klára Lázár-Gerő, and Géza Róheim. During the war, no further data were available. In 1944, as with most of the European associations-the Danish, Dutch, French, and Swiss-the Hungarian Society showed little sign of life. . . Tragically, several Hungarian psychoanalysts were killed in the concentration camps and by war in 1944 and 1945. (Mészáros 2012, 92-93)

There is a lot more to say to bring the story up to date in the light of the enforced closure of the Hungarian Psychoanalytical Society in 1949 and its resonance with further, now Stalinist, anti-Semitism, but this is perhaps sufficient context. In Hungary, where the conference from which this publication arises took place, there is a complex psychoanalytic history that-as is the case in many other places-is deeply infused with the crises of twentieth century authoritarian politics.

\section{Politics}

The links between psychoanalysis and politics are deep-rooted and provocative. There are, for instance, many examples of the ways in which psychoanalysis has been used as an instrument to advance progressive politics by supplying a theory of the social subject that is compatible with radical critique and a practice that is emancipatory. These examples stem from pre-World- 
War-II Europe and arguably can be seen to have their source in Freud's own late "social" texts (e.g., Freud 1930). After the war, they went relatively quiet until taken up by Herbert Marcuse's Eros and Civilization (1955) and the expansion of a radical community, mostly outside the psychoanalytic movement, and a strong infusion of feminist critique that did in some cases include feminist psychoanalysts (or feminists who became psychoanalysts, e.g., Mitchell 1974; see also Frosh 1999 and Zaretsky 2015). Here, however, I want to take up another aspect: the fact that however much psychoanalysis lends itself to progressive thinking, it also shows a repeated tendency to drift institutionally towards conformity. This is, of course, never the whole story: wherever psychoanalysis conforms, we find analysts who oppose this process, and there have also been strong institutional examples of progressive politics, for example in the "free psychoanalytic clinics" movement of the 1920s and 1930s in Berlin, Vienna, London, and importantly in Budapest (Danto 2005), or even the British Psychoanalytic Society's opposition to nuclear arms in the 1990s (Segal 1995). But conformism has been visible and at times has manifested itself in situations where one might hope that psychoanalysis would come into its own as an ethical practice of political resistance. I do not, of course, believe that this is a phenomenon unique to psychoanalysis: plenty of professional organizations have shown themselves only too ready to leap to attention when required to do so by the "authorities." But it is especially instructive to see psychoanalysis, the "science" of the unconscious, struggling with its own unconscious, to some extent at least, unawares.

\section{Conformity and Criticality}

\section{NEUTRALITY}

Let me work with an example here, relating to the question of psychoanalytic "neutrality" and its effect on psychoanalytic institutions. Neutrality properly refers to the stance of the psychoanalyst as "at a point equidistant from the id, the ego, and the superego" (A. Freud 1937, 28), reflecting the idea that the analyst should maintain a neutral thinking function resistant to hasty judgment. More fully, Laplanche and Pontalis $(1973,271)$ direct as follows:

The analyst must be neutral in respect of religious, ethical, and social values-that is to say, he must not direct the treatment according to 
some ideal, and should abstain from counselling the patient; he must be neutral too as regards manifestations of transference (this rule usually being expressed by the maxim, "Do not play the patient's game"); finally, he must be neutral towards the discourse of the patient: in other words, he must not, a priori, lend a special ear to particular parts of this discourse, or read particular meanings into it, according to his theoretical preconceptions.

This is the kind of neutrality that allows something to happen, playing a waiting game to see what will emerge, refusing to censor, and in consequence supporting not only the disturbing and potentially disgusting, but also, relatedly, the radical and new. Censorship always reflects the status quo; it derives from an assumption about what is proper and tolerable, what is safe and respectable. Neutrality in the way it is described here undermines censorship precisely by not taking sides.

This particular version of neutrality has been significantly challenged by relational analysts and others who not only register the impossibility of not making one's values felt but who also see the attempt to do so as a way in which the analyst avoids taking responsibility for the effects of her or his presence and activity in the psychoanalytic encounter (e.g., Benjamin 2004). The appeal to "neutrality" can also produce modes of political conformism that both undermine psychoanalysis' claims to be a progressive discipline and reveal aspects of its "unconscious" formation. The issue here is that the "neutrality" with which the analyst faces the patient becomes interpreted as "neutrality" in relation to the external world and specifically to political processes, even when these impinge very strongly on the mental well-being of patients and of populations, and indeed on the possibility of a "neutral" psychoanalytic encounter, free from undue external "impingements."

I want to present two specific instances here, extremely briefly. I have written about them both elsewhere in more detail, and reproduce some of this material in what follows; ${ }^{1}$ but in the discussion, I want to come back to the question of what it might mean to consider psychoanalysis "in troubled times."

1 The next two sections are extracted and abbreviated from Frosh 2005 and from Rubin et al. 2016. 


\section{GERMANY}

The first comes from the now well-mined history of psychoanalysis in Germany during the Nazi period. There is a lot that one could say about this, and here I am going to very selectively present a tiny amount of material to raise the issue of the corrosiveness of what purports to be psychoanalytic "neutrality" but can so easily become complicity. By the early 1930s, German psychoanalysis was a model for how psychoanalysis might be practiced and developed in an advanced society. Yet, within a remarkably short time after the accession of the Nazis to power in 1933, all this had gone. Max Eitingon, who had headed the German Psychoanalytic Society (DPG), left for Palestine, and the DPG was taken over by two non-Jewish analysts who effectively became collaborators with the Nazis: Felix Boehm and Carl Müller-Braunschweig. With the active connivance of Ernest Jones, the DPG was "Aryanized" by the end of 1935, nearly three years before other Jewish professionals, such as lawyers and doctors, were excluded from their equivalent organizations. By 1936, Otto Fenichel could comment that the "Aryan" members of the DPG "are avoiding any contact-both the slightest professional contact as well as personal contact-with their non-Aryan colleagues" (Eickhoff 1995, 950). The exclusion of the Jews was embraced with some enthusiasm by their non-Jewish erstwhile colleagues, whether because of fear of being associated with the specifically derogated marginality of the Jews, or because of active anti-Semitism.

The pressure to resign under which the Jewish analysts were put can be seen as a version of the famously brusque treatment meted out by the psychoanalytic movement to Wilhelm Reich. Reich had been regarded as an analyst of considerable promise in Vienna in the 1920s, where he had conducted a highly regarded seminar on therapy, a seminar that bore fruit in his 1933 classic, Character Analysis. Moving to Berlin, he joined the communist party in 1930 and caused dissent within it because of his views on the gravity of the working classes' defeat with the advent of Hitler, as well as because of his promotion of sexual liberation (Sharaf 1983). From that time on, he became increasingly involved both in a theoretical project to link Freudianism with Marxism and in practical politics surrounding sexual reform; along with Fenichel, he was the acknowledged leader of the "political Freudians" (Jacoby 1983). Increasingly, however, Reich's ideas diverged from Freudian psychoanalysis, becoming more biological in focus and less interested in the fantasy dimensions of psychic life. More relevantly, his political radicalism was concerning within the psychoanalytic movement, with Freud himself demon- 
strably critical. With the Nazis in power, the threat posed by "political" activity to the safety of psychoanalysis within Germany was seen by Freud as well as by Jones as potentially extremely damaging, and Reich was its most flagrant exponent. Anna Freud's letter to Jones from April 27, 1933, shows the reasoning as well as the emotion:

My father's opinion on this matter is: If psychoanalysis is to be prohibited, it should be prohibited for what it is, and not for the mixture [or "hodgepodge"] of politics and psychoanalysis which Reich represents. My father can't wait to get rid of him inasmuch as he attaches himself to psychoanalysis; what my father finds offensive in Reich is the fact that he has forced psychoanalysis to become political; psychoanalysis has no part in politics. (Steiner 2000, 128)

Promotion of the idea that "psychoanalysis has no part in politics" was a key element in the defense of psychoanalysis against the Nazi critique of its inherently destabilizing nature, and this was precisely the line taken by Boehm and Müller-Braunschweig in their negotiations with the Nazis. Boehm did this explicitly by arguing to the Nazis that there were two kinds of psychoanalysis: the genuine version, which could be of service to the state, and the other, distorted, politicized version brandished by Reich. That this paved the way for a distinction between "pure" and "Jewish" psychoanalysis was not a point made explicitly, but it was clearly a move made available by this rhetoric about "two types of analysis." Freud himself had taken the view that Reich and Fenichel had been using the International Zeitschrift für Psychoanalyse, of which Fenichel was editor, for "Bolshevik propaganda," a result of which was that Fenichel lost his position (Nitzschke 1999, 353). As implied in Anna Freud's letter, Freud was actually quite brutal in his view of what should happen to Reich. Writing to Eitingon in 1933, he commented, "Since Reich is now causing trouble in Vienna, he should be removed from the DPG. I want this done for scientific reasons but have no objection to it being done for political reasons as well and wish him success if he wants to play the martyr" (Nitzschke 1999, 355). Preserving psychoanalysis by getting rid of troublemakers had always been one of Freud's strategies and has never been alien to psychoanalytic institutions' way of operating. Here this approach was additionally fuelled by the hope that depoliticizing psychoanalysis by excluding its wildest radical would convince the German authorities that it should be judged on its "scientific" merits alone. 
As it turned out and as Reich and a few others were prescient enough to see, this "non-political" attitude effectively paved the way for a partial Nazification of psychoanalysis, while depriving psychoanalysis of its crucial critical role. It also resulted in the "secret" expulsion of Reich from the DPG and the International Psychoanalytic Association (IPA) in the summer of 1933, a decision that Reich seems not to have known about until he arrived at the Lucerne Congress of August 1934, when Müller-Braunschweig informed him that he had been expelled from the DPG a year earlier. Over the course of that congress it became apparent to Reich that the leadership of the IPA endorsed this decision. Jones later claimed that Reich had resigned from the IPA at that congress, but this, it seems, was never Reich's view (Sharaf 1983, 188).

Jacoby (1983) has discussed some of the complex politics surrounding Reich at this time, pointing out that he did not have the unequivocal support even of the "political" Freudians, notably Fenichel. However, the key point here is not so much how difficult Reich was even for those who might be seen as potentially aligned with him, but rather that from Freud down, the early period of Nazi rule in Germany was seen as requiring extreme caution concerning any potentially subversive political involvement, and that the consequence of this was that the politics of the psychoanalytic movement itself began to be played out under the shadow of Nazi demands. In particular, splitting the presentation of psychoanalysis so that it appeared that its political, or at least socially critical, dimension could and should be divorced from its "scientific" claims, was a strategy employed to make psychoanalysis seem safe and useful to the new German authorities. However, this strategy was not only parallel to, but formed a metaphoric unity with the splitting of the movement between its "Jewish" and "Aryan" components, the former being what marked it as potentially subversive and parasitic, whereas the latter made it serviceable. The seeds of psychoanalysis' later absorption into the dejudaicized "New German Psychotherapy" were very strongly sown here: without its critical dimension and without its Jewish elements (both people and ideas), it would indeed survive, but only subserviently, as a technology devoted to making citizens productive.

\section{BRAZIL}

My second example comes from one of the most "psychoanalytic" countries in the world, Brazil, which has a long and complex history of engagement with psychoanalysis as a "modernizing" force in a context in which racial 
and sexual "primitivity" were seen as requiring understanding and control (Plotkin 2011). After World War II, Brazilian psychoanalysis was organized according to an idealized version of the IPA's protocols, in the sense that it sought orthodoxy as a way of becoming recognized-an instance of a kind of "colonial" dependency present in many Brazilian professional and academic environments. Part of this orthodoxy was adherence to political neutrality, an issue that came to a head during the period of the Brazilian dictatorship in the 1960s and 1970s, especially during the ultra-violent "years of lead" (19681974). In this period, which saw a perhaps surprising expansion of "official" psychoanalysis in the country (Russo 2012), an event occurred in which the societies recognized by the IPA in Rio de Janeiro, under the guise of neutrality and "safeguarding psychoanalysis," covered up participation in torture and repression. This episode was documented by Helena Besserman Vianna in her 1994 book Don't Tell a Soul. The book title was inspired by a 1993 request by an official of the IPA that the author, who was in some ways a "victim" of the affair, not talk about this subject any more.

The case began in 1973, when a clandestine revue published a note naming some "torturers" in Rio de Janeiro; included in the note was the name of Amilcar Lobo, a trainee analyst in one of the psychoanalytic institutes in Rio de Janeiro ("Rio 1"). Lobo had been in analysis for years with Leão Cabernite, who at the time was the President of Rio 1 and the Brazilian Psychoanalytic Association. The note was anonymously forwarded to a psychoanalytic journal in Argentina edited by Marie Langer. Information about it soon spread, first through letters sent by Langer to the presidents of the IPA and COPAL (the Psychoanalytic Confederation of Latin America). Subsequently, a letter sent to COPAL and signed by Cabernite and two other members of the Board of Directors of Rio 1 castigated the denunciation as "entirely false and empty of any foundation." The IPA president Serge Lebovici accepted this and no further investigation was undertaken. After Vianna, a trainee with the other IPA institute in Rio ("Rio 2"), was revealed by a graphologist as responsible for the anonymous letter, Rio 1 wrote to Rio 2 requesting punishment for someone whose intention was to "destroy and demoralise Brazilian psychoanalysis" (Vianna 1994, 46). From this point on, Vianna's career was systematically undermined.

By the early 1980s, and because of a gradually changing situation in Brazil, information on the accusations and cover-up were seeping out. During a public seminar about psychoanalysis and Nazism, a participant announced himself as a former political prisoner and claimed that he had seen Lobo 
among the torturers. Following that, Rio 1 finally decided to expel Lobo; however, they also expelled Helio Mascarenhas and Eduardo Pellegrino, two politically active members of Rio 1, for having talked about "forbidden subjects"-i.e., the Lobo affair-outside the society. This triggered a larger institutional crisis between followers of Cabernite and an opposition that defended Pellegrino and Mascarenhas (Vianna 1994, 88). Adam Limentani, the IPA president, acknowledged the crisis between the two groups in Rio 1, and decided to freeze the society and send a Site Visit Committee chaired by Robert Wallerstein to examine the situation. After the visit, a series of institutional requirements was stipulated as a condition of the Rio 1 society recovering its independence. This included barring Cabernite from any administrative responsibility in Rio 1 (Wallerstein 1999, 970). The Committee did not, however, demand Cabernite's expulsion for what Wallerstein later called his "grossly unethical behavior" and they did not put their requirements into writing because "it was a gentlemen's agreement between persons of presumed good will” (Wallerstein 1999, 970). In 1989, Lobo published his autobiography in which "he defended his four years of participation in the torture squads and acknowledged that, as his training analyst, Cabernite was completely aware of his activities" (Hildebrand 1999, 31).

In 1993, the IPA Executive learned that Cabernite had not only remained a major influence in the society, but that he was also being honored for his distinguished leadership. Faced with this situation, and only after heated debate, the decision to expel Cabernite was made. Rio 1's refusal to accept both the IPA's recommendation and the conclusions of their own Ethical Committee led to a major split within the society; six members resigned and another thirty withdrew, creating a new opposition group. According to the Bulletin of this group, the mantra of IPA apoliticism was still operating as of 1998, when Otto Kernberg, while paying a visit to Brazil, refused to talk to the dissident groups in Rio, stating that "when psychoanalysis is made into a political movement, we are no longer on the grounds of psychoanalysis." Further, he accused the group of conspiring to defame psychoanalysis and asserted that it was "destructive, perverted, and anti-ethical, they resented the fact they could not leave the past behind" (Hildebrand 1999, 32-33). Overall, the IPA and the local Brazilian societies came out of this affair badly. Instead of speaking up against torture and violence, they were, at best, too easily deceived, and at worst complicit in covering it up, even after the period of state terror had passed. Inaction was officially cloaked by the ideology of "psychoanalytic neutrality" or justified through the logic of "safeguarding psychoanal- 
ysis." The IPA never genuinely tackled the issue of how psychoanalysis had itself come to be connected with torture, totalitarianism, and repression; how it avoided taking a stance against it; and how it renounced its ethical responsibility by adopting a so-called neutral posture.

It is worth noting, somewhat speculatively, how the Cabernite-Lobo Affair echoes some transgenerational analytic continuities. The profile of European psychoanalysts who migrated to Brazil after World War II critically shaped the history of Brazilian psychoanalysis, especially its official societies. One important figure was Werner Kemper, who arrived in 1949 to help meet the demand for training analysts in Rio. Kemper had been the director of the polyclinic in the so-called Göring Institute in Germany during World War II, and was a collaborator with the Nazi regime (Goggin and Goggin 2001). Kemper was Cabernite's analyst. It is of course simplistic to claim that there is a direct link between the failure of the IPA to deal with the Nazi heritage of some German analysts like Kemper and its failure to deal with the complicity of some Brazilian analysts involved with the violent dictatorship in that country. Nevertheless, it is noteworthy that Kemper's Nazi connections seem to have evoked little interest when he moved to Brazil; it was more important that he was a "proper" psychoanalyst who could help establish an official society. One cannot know what transpired between him and Cabernite in Cabernite's analysis, but the silence regarding Kemper's past during that period parallels the silence that reigned over and was preserved for as long as possible in the Lobo case. What might be seen here is a tendency towards an institutional defense against uncomfortable truths, manifested not only in turning away, but also in very active and at times vicious practices of denial. Perhaps one can also add that the pretense that nothing has happened represents a forgetting of history that one might have expected psychoanalysis, of all disciplines, to be protected against. But, of course, it is not.

\section{Conclusion}

I have suggested that, in some of its institutional history, psychoanalysis reveals how it can develop normalizing and conforming tendencies that are at odds with its more progressive aspects. I take these "progressive" parts of psychoanalysis to be more true to the psychoanalytic mission as a whole, as they derive from its conditions of formation in the social revolution of the late nineteenth and early twentieth centuries and also reflect its potential- 
mimicking that of the unconscious-for disturbing the comfort of the status quo. Nevertheless, the pull of an intergenerational collusion with repression that is based on silence and denial is very strong, especially when-as in the Brazilian case-it is tied to a social orthodoxy of normalization and a history of colonial deference. When tested to the extreme, it can produce behavior that might be termed "symptomatic" of the presence of something not fully worked through, in this case, corruption that has a lineage back to Nazism and the destruction of the psychoanalytic ethic.

The question to end with concerns the conditions under which psychoanalysis might sustain its progressive enterprise when faced with authoritarianism, and those under which it might not. As we have seen, the latter can come about for a number of interlinked reasons, including the understandable anxiety of individuals faced with real threats to their safety; and also the equally understandable uncertainty people might have when confronting a confusing situation that is outside their usual experience, which is fast-changing and potentially dangerous. Appeasement of the Nazis in the early years of their rule in the 1930s, for example, only looks completely and obviously wrong-headed with hindsight. At the time, it was not necessarily (though it was sometimes) a culpable stance, as people were desperate to avoid a repeat of the mindless bloodletting of the previous war, about which many of them felt guilty.

But conforming to authoritarianism can also occur through opportunism (some of the non-Jewish analysts in Germany seem not to have minded too much that the Jews with whom they had to compete for jobs were no longer on the scene) and also because there are some elements within psychoanalysis itself that could be activated under such conditions. For example, there is evidence that the growth of "official" psychoanalysis in Argentina during the years of the murderous junta was aided by psychoanalysis' appropriation of a medicalized treatment discourse that could be seen both as privatizing and pathologizing social unease. Additionally, its adoption of familial ideology could be aligned with the views of the Catholic Church, with which the leadership was associated (Plotkin 2012). Some of the same issues might have been at play in Brazil, building on a tradition in which psychoanalysis was deployed as part of a normalizing "modernization" process aimed at taming the fantasized "wildness" of the Brazilian character (Plotkin 2011). In the German case, the broader ambivalence about psychoanalysis' "Jewishness" was very notable, though this may not have been a significant element in the treatment of Wilhelm Reich. What was more important there was the immo- 
bilizing anxiety produced by the times, and the inability of the leaders of the psychoanalytic movement (including Freud) to understand the extent of the political earthquake with which they were faced. Here too, however, there is a systematic point to make: psychoanalysis' tendency to withdraw into the personal, to focus on the "inner" can be seen as an important strength; this is, after all, primarily what it does and how it works. But its weakness is also clear: abstracting itself from the social and political context in which its patients, its analysts, and its institutions function, it can become reductive and backward-looking, pathologizing and individualizing social suffering rather than understanding its sources and what might have to be done to contest it. The famous dictum, attributed to Lacan, that "cobblers stick to shoes" has something to it: psychoanalysts cannot claim expertise over the social and political sphere just because they are psychoanalysts. What they do, or should, know about is the unconscious and how it functions in the psychoanalytic setting. Nevertheless, if that is all they know and can permit into their consciousness as psychoanalysts as well as citizens, then they are unlikely to be able to stand up to an authoritarian regime that "impinges" (to use a psychoanalytic word) on the well being of their patients and their practices. As far as it is possible to tell, in both Germany and Brazil, those psychoanalysts who suffered were not persecuted because they were psychoanalysts; rather, it was either because they were Jews (in Germany) or radicals (in both countries). Both these things might have also attracted them to psychoanalysis, but it was not in the essential nature of official psychoanalysis that this should be so.

My terminology of "official" psychoanalysis is clearly both vague and disputable. There are many "official" psychoanalyses, and as characterizes a liberal profession, there are also many analysts who do not adhere particularly strongly to any viewpoint laid down by the societies to which they belong. However, there is something to note in the way the IPA-recognized societies in Germany and Brazil operated in the troubled times to which this chapter refers. What is "official" is institutionalized and bureaucratized and becomes dependent on, and fascinated by, wider social acceptance and approval by the centers of power in any society. This might even be more strongly true of a discipline like psychoanalysis, which is always in danger of being marginalized and seen as both sordid and subversive (for instance, because of its fascination with sexuality), than it is of other more "respectable" disciplines like medicine or law. Being "official" in this way leaves it drawn towards subservience, as if the more explosive the unconscious material with which it deals, the more conformist it might have to be to contain this and be a "normal" 
element in society. If this is what dominates, if "official" acceptability and influence is the goal, then the supposed neutrality with which psychoanalysis is so enamored becomes identical with social and political conformism, which under the right conditions can lead to the reactionary responses sketched here. When psychoanalysis began in the 1890s with Freud, it was a marginal discipline and practice. This was never a comfortable situation to be in, but perhaps this kind of discomfort can inoculate it, to some degree, against the danger that when times are troubled, as they quite often are, it will lose its bearings and its ethical standing.

\section{REFERENCES}

Benjamin, Jessica. 2004. "Beyond Doer and Done To: An Intersubjective View of Thirdness." Psychoanalytic Quarterly vol. 73, no. 1: 5-46.

Danto, Elizabeth A. 2005. Freud's Free Clinics: Psychoanalysis and Social Justice. New York: Columbia University Press.

Eickhoff, Friedrich. 1995. "The Formation of the German Psychoanalytical Association (DPV): Regaining the Psychoanalytical Orientation Lost in the Third Reich." International Journal of Psycho-Analysis 76. no. 5: 945-56.

Erlich, Shumuel, Mira Erlich-Ginor, and Hermann Beland. 2009. "Being in Berlin: A Large Group Experience in the Berlin Congress." International Journal of Psychoanalysis 90. no. 4: 809-25.

Freud, Anna. 1937. The Ego and the Mechanisms of Defence. London: Hogarth Press. Freud, Sigmund. 1930. "Civilization and Its Discontents." The Standard Edition of the Complete Psychological Works of Sigmund Freud. Volume XXI, (1927-1931): The Future of an Illusion, Civilization and Its Discontents, and Other Works, 57-146. London: Hogarth Press.

Frosh, Stephen. 1999. The Politics of Psychoanalysis. London: Macmillan. . 2005. Hate and the Jewish Science: Anti-Semitism, Nazism and Psychoanalysis. London: Palgrave.

- 2012. "The Re-Enactment of Denial." In Re(con)figuring Psychoanalysis: Critical Juxtapositions of the Philosophical, the Sociohistorical and the Political, edited by Aydan Gulerce, 60-75. London: Palgrave.

Goggin, James, and Eileen Goggin. 2001. Death of a "Jewish Science": Psychoanalysis in the Third Reich. West Lafayette: Purdue University Press.

Hildebrand, Peter. 1999. "The Cabernite Affair." Bulletin of the British Psychoanalytical Society (January): 30-34.

Jacoby, Russell. 1983. The Repression of Psychoanalysis. New York: Basic Books.

Kovács, András. 2012. "Antisemitic Prejudice and Political Anti-Semitism in PresentDay Hungary." Journal for the Study of Anti-Semitism 4: 443-67.

Laplanche, Jean, and Jean-Bertrand Pontalis. 1973. The Language of Psychoanalysis. London: Hogarth Press. 
Marcuse, Herbert. 1955. Eros and Civilization. Boston: Beacon Press.

Mészáros, Judit. 2012. "Effect of Dictatorial Regimes on the Psychoanalytic Movement in Hungary before and after World War II." In Psychoanalysis and Politics: Histories of Psychoanalysis under Conditions of Restricted Political Freedom, edited by Joy Damousi and Mariano Plotkin, 79-108. Oxford: Oxford University Press.

Mitchell, Juliet. 1974. Psychoanalysis and Feminism. Harmondsworth: Penguin.

Nitzschke, Bernd. 1999. "Psychoanalysis during National Socialism: Present-Day Consequences of a Historical Controversy in the 'Case' of Wilhelm Reich." Psychoanalytic Review 86, no. 3: 349-66.

Plotkin, Mariano. 2011. "Psychoanalysis, Race Relations, and National Identity: The Reception of Psychoanalysis in Brazil." In Unconscious Dominions: Psychoanalysis, Colonial Trauma, and Global Sovereignties, edited by Warwick Anderson, Deborah Jenson, and Richard Keller, 113-37. Durham: Duke University Press.

Plotkin, Mariano. 2012. "The Diffusion of Psychoanalysis under Conditions of Political Authoritarianism: The Case of Argentina, 1960s and 1970s." In Psychoanalysis and Politics: Histories of Psychoanalysis under Conditions of Restricted Political Freedom, edited by Joy Damousi and Mariano Plotkin, 185-208. Oxford: Oxford University Press.

Rubin, Aline, Belinda Mandelbaum, and Stephen Frosh. 2016. "No memory, no desire': Psychoanalysis in Brazil during Repressive Times." Psychoanalysis and History 18, no. 1: 93-118.

Russo, Joy. 2012. "The Social Diffusion of Psychoanalysis during the Brazilian Military Regime: Psychological Awareness in an Age of Political Repression." In Psychoanalysis and Politics: Histories of Psychoanalysis under Conditions of Restricted Political Freedom, edited by Joy Damousi and Mariano Plotkin, 165-84. Oxford: Oxford University Press.

Segal, Hanna. 1995. "From Hiroshima to the Gulf War and After." In Psychoanalysis in Contexts, edited by Anthonoy Elliott and Stephen Frosh, 191-204. London: Routledge.

Sharaf, Myron. 1983. Fury on Earth: A Biography of Wilhelm Reich. London: Hutchinson.

Steiner, Ricardo. 2000. "It Is a New Kind of Diaspora": Explorations in the Sociopolitical and Cultural Context of Psychoanalysis. London: Karnac.

Vianna, Helena. 1994. Não Conte a Ninguém-Contribuição à história das Sociedade Psicanalíticas do Rio de Janeiro. Rio de Janeiro: Imago.

Wallerstein, Robert. 1999. "Commentary on 'Politique de la psychanalyse face à la dictature et à la torture: N’en parlez à personne’ by Helena Besserman Vianna.” Journal of American Psychoanalytic Association 47: 965-73.

Zaretsky, Eli. 2015. Political Freud. New York: Columbia University Press. 



\title{
Psychoanalysis and Taking Sides: Two Moments in the History of the Psychoanalytic Movement
}

\author{
Julia Borossa
}

Hannah Segal's essay, "Silence Is the Real Crime," poses a challenge to the institution of psychoanalysis that has yet to be met. Considering the specific role of the psychoanalyst as a working practitioner faced with the facts of injustice and the abuse of human rights, she states the following:

I think we have a specific contribution to make. We are cognizant with the psychic mechanisms of denial, projection, magic thinking, and so on. We should be able to contribute something to the overcoming of apathy and self-deception in others and ourselves. When the Nazi phenomenon was staring us in the face, the psychoanalytic community outside Germany was largely silent. This must not be repeated. Nadezhda Mandelstam said: "Silence is the real crime against humanity." We psychoanalysts who believe in the power of words and the therapeutic effect of verbalizing truth must not be silent. (Segal 1987, 127)

These are strong words coming from a woman with a distinguished record of service within the International Psychoanalytic Association, and for all the apathy and ambivalence invoked, there is something quite fundamental about the ethical and political demand that psychoanalysis as a particular institution faces. I would suggest that it has to do precisely with the question of continuous commitment to both thought and action, and not turning away from facts that are sometimes undeniable. But this may sometimes require taking 
sides and, as Stephen Frosh suggests, critical engagement with the idea of analytic neutrality (Frosh 2007).

Many critics of psychoanalysis have concentrated on its failures to address anything beyond the "know thyself" of the individual mind. The knowledge that psychoanalysis proposes would appear to be primarily of a private, apolitical nature, in which the only ethics available is an ethics of truth, and the only truth possible is one that recognizes self-deception as a basic human condition. From the point of view of demands for a political and ethical vision, the fault lines of psychoanalysis, as understood in this manner, appear to be present from the outset. It is significant that among the earliest critics of Freud were Marxist intellectuals such as Bakhtin and Voloshinov, who wrote in the 1920s and 1930s. While the psychoanalyst as a clinician aims to listen to the analysand's free associations with evenly suspended attention and a neutral stance, and the space of the consulting room may be one of privileged privacy, the exchange between analyst and analysand is also inevitably social and political through and through, and some of Freud's earliest companions were well aware of and actively promoted social justice via the establishment of free psychoanalytic clinics (Danto 2005). Moreover, as this chapter will argue, psychoanalysis as a practice is inseparable from the question of psychoanalysis as a specific institution, which inevitably locates such an exchange. Furthermore, it is a matter of its institutional geography, which was originally largely co-extensive with western colonialism, and now can be seen to be associated with economic globalization, especially given the rapid spread of psychoanalytic study circles supported by supervisionby-Skype, for example in China. In 1981, when Derrida wrote his landmark essay "Geopsychoanalysis: '. . . and the Rest of the World," he argued that "the Association's main geographical areas [were] defined as America north of the United States-Mexican border; all America south of that border; and the rest of the world" (Derrida 1991, 199). He went on to argue that the loosely defined inclusiveness of that formulation, "rest of the world," functions as:

A title, a name and a location shared by the roots of psychoanalysis and everything which, since it lies beyond the boundaries of psychoanalysis, has yet to be opened up to it-all expectations in this regard being legitimate; a sort of Far West or no man's land, then-but also a sort of foreign body named, incorporated and circumscribed ahead of time by an IPA Constitution, rehearsing, as it were, the psychoanalytic colonisation of a non-American rest-of-the-world, the conquest of a virginity parenthetically married to Europe. (Derrida 1991, 201) 
The IPA's statutes still divide this territory into these three main geographical areas, though the phrasing is slightly different: Europe (plus Australia, Israel, and India); Latin America (the Western hemisphere, excluding the United States and Canada); and North America (the United States, Canada, and Japan). It makes for a very strange rearrangement of the map of the world, revealing and concealing so much. One can argue that the disavowals of psychoanalysis have much to do with the inability of its theories to adequately account for the material conditions within which our psychic selves evolve. One may even say, in light of the above, that it is blind to the very shape of the world, but also to the multiple histories of colonization, conquest, trade, oppression, and dictatorship, which nevertheless insist on escaping their concealment. With sufficient attentiveness, awareness, and interest, these can indeed be read into this list of continents and nation states, both those named and those not. There are so many potential stories to be told, which may include the vicissitudes of the deployment of psychoanalysis in Southern Africa, Lebanon, Iran, Egypt, and Palestine. Some of these stories have begun to be explored; yet there remains much silence even amidst an apparent discursive opening up.

Furthermore, in its persistent privileging of individual processes of repetition working through, and mourning over social ones; and/or modeling social processes on individual or narrowly familial ones, psychoanalysis has often been content with a kind of memory work that indicates, as Dominick La Capra $(1998,8)$ puts it in a different context, "a failure of constructive will and diverts attention from the needs of the present and the necessity of attempting to shape the future." In the present study, however, I wish to relate two instances of psychoanalytic practice conducted during specific socio-historical moments: South Africa in the 1930s and Brazil in the early 1970s. In both cases, the "political" could be seen to insist in a particular way, pushing the analytic relationship to its ethical limits. Moreover, the violence of social relations runs through each case as the trope that disturbs complacency.

\section{Are We Colleagues? The Psychoanalyst and the Witch Doctor Under Colonialism}

The first story I wish to tell is that of Wulf Sachs's therapeutic encounter with John Chavafambira in 1930s South Africa. Chavafambira was a migrant worker from Southern Rhodesia and the descendant of a long line of witch doctors, and this encounter formed the basis of a book Sachs published in 
1937 under the title Black Hamlet, re-published more recently with a substantial introduction by Saul Dubow and Jacqueline Rose (Sachs 1996).

Sachs was an unconventional figure in the history of psychoanalysis and the first person to practice psychoanalysis in Africa. Of Jewish Lithuanian descent, he was brought up in St. Petersburg and trained as a doctor in Cologne and then London, before he emigrated to South Africa with his family in 1922, eventually specializing in psychiatric work. He began reading Freud, which led him back to Europe in 1929 to train in Berlin with Theodor Reik, and he later became an affiliate member of the British Psychoanalytic Society.

Sachs returned to Johannesburg seeking to consolidate the institutional basis of psychoanalysis in his adopted country and spread a general understanding of Freudian thought; he assembled a small group of like-minded colleagues to help him in this endeavor. As a whole, his project involved an explicit challenge to the hierarchical assumptions of colonial psychiatry with the help of psychoanalysis' own universal categories, and in this he can be seen as a somewhat less radical precursor to Frantz Fanon (Borossa 2007). For example, Sachs (1933) published an account of his work with African patients in an asylum in Pretoria called "The Insane Native: An Introduction to a Psychological Study." Here, he adopted a Freudian model of psychosis in order to insist on the similarity between the psychology of the European and the African subject in a state of madness and, by extension, in normality. In defending his view of the universal nature of the human psyche, Sachs was coming up against the basic foundations of colonial psychiatry as a discipline which set for itself the task of understanding "the nature of the native mind," which from the outset was believed to be different from the European mind, and which took for granted the "imperfectability" of the colonial subject (Vaughan 1991). For example, B. J. F. Laubscher, a psychiatrist who worked in South Africa at the same time as Sachs and also used Freudian concepts in his book Sex, Custom, and Psychopathology: A Study of South African Pagan Natives $(1937,84-85)$ argued in its pages for the affinity between the psychotic European and the "normal" African. Sachs was also at odds with the official politics of a society that was legitimating itself through the separation and hierarchization of races, and the idea of the inferiority, even the innate pathology of the indigenous population.

Sachs's significant book, Black Hamlet, was the result of his wish to follow up on the thesis of his article by undertaking a full study of a typical black African person in order to demonstrate the affinity between his patient's psychology and that of the European. His patient Chavafambira was a migrant worker from what is now Eastern Zimbabwe and was the last in 
a long line of ngangas, or witch doctors, though he was living in hardship in Johannesburg. The title of the book reflects the parallel that Sachs draws from the familial position of Chavafambira and the story of Hamlet. With his father's death, his mother married her dead husband's brother as was customary, and Chavafambira found himself in a situation of intense rivalry with his uncle, who like his father was also a nganga. His dilemma was his need for vengeance in the narrow context of the family. Sachs $(1996,236)$ defines his suffering as a form of Hamletism "a universal phenomenon symbolising indecision and hesitancy when action is required and reasonably expected." However, the text, written of course by Sachs, is also presented as the story of an unfolding dialogue between the two men: the psychoanalyst and the witch doctor, based on "a kind of interchange of medical knowledge" (74). Such an exchange, however, is circumscribed by the power relations of analysis (Sachs is mainly in the position of patient), and relativized by the fact that the two discourses are not on a par, particularly as they unfold under social circumstances of profound social discrimination. It was at that very time that a series of segregationist laws were being introduced, preparing the terrain for apartheid. Sachs was certainly sensitive to this and to the practical circumstances in which his patient/interlocutor was forced to live, and he was also attentive to what Chavafambira revealed to him about the limitations of psychoanalysis. Their relationship reached a crisis point after Chavafambira's arrest and torture as a suspect in a murder of twins.

He tried to explain to the detectives, but in vain. The stout one probed further and further, refusing to be satisfied. It seemed to John as if these white people put their meddlesome hands into his very thoughts, ruthlessly tearing and digging out information. The two of us, the detective and myself, thus fused in John's mind into one voice, one set of features, separated and regained their individuality, approached each other till they reminded him of a picture of Siamese twins that he had seen in one of my books. Slowly, one would be superimposed upon the other till the detective and I became one; and then instantly they would spring apart again and become two, widely separated, entirely distinct. It was a terrible thought. (Sachs 1996, 213)

It was a terrible thought indeed, the fusion of the torturer and the psychoanalyst, which Sachs could not deny-in the context of their analytic relationship, taking place as it did, at that particular time and place-and, in fact, he could 
only reinforce it as Chavafambira sought to break off their dialogue, which he now found unbearable. Tellingly, Sachs decided "to interfere and break down his resistance" via psychoanalytic theory (explaining the aggressive instinct to him, and so on "until I won ... and the months that followed were the most successful of our relationship" (Sachs 1996, 214-15). The victory, however, was not as it first appeared, the victory of an immutable psychoanalysis, for the continuation of the dialogue was dependent as well on a transformation in Sachs's conception of his role as a psychoanalyst. This he now understood as inseparable from the need to address the practicalities of Chavafambira's life, something which he increasingly did, encouraging Chavafambira's education and politicization.

Outside the consulting room, Sachs became active in left-wing politics and journalism. Sachs revised his text in 1946, republishing it under the title Black Anger; excising passages where the analyst could be seen at his most patronizing in his superior conduct towards the witch doctor; and emphasizing the importance of Chavafambira's own politicization. In both versions of the text, "inaction" is presented as the disease and politicization the "cure," although it is still clearly Chavafambira whose inaction stood to be "cured." Furthermore, as Jacqueline Rose clearly points out, the implicit demand on Chavafambira is to renounce his ancestral vocation in order to participate in a universalist Enlightenment project, one in which psychoanalysis clearly has its place (Dubow and Rose 1996). However, Sachs's conclusion in the revised and expanded Black Anger is striking, as he notes the change in his patient/ interlocutor, Chavafambira, and by implication in himself.

He was no more merely a nganga to give them what inspiration they could derive from shells and bones and herbs. John by now had become an effective protagonist. ... He addressed small groups ... pointing out the dangers of violence, which would lose them the sympathy of the many whites who for once stood solidly behind them. . . . He was looking beyond towards a new vision-a bond with his people in America. ... And thus it was that this story, which was to have been about John the subject of a psychoanalytic study to be read by a limited number of scientists, became the story of John, the man, written to be read by everyone. (Sachs 1968, 323-24)

But would it work if some of the terms were transposed? What changes could be deduced in Sachs himself? It could be an interesting exercise to revise the 
quotation in order to explore whether psychoanalyst and nganga may be inverted, and whether it may speak to Sachs's own increasing politicization and activism. Could it be something of a rallying call for a psychoanalytic practice that could withstand disavowal and the politics of denial?

$[\mathrm{H}] \mathrm{e}$ was no more merely a psychoanalyst to give them what inspiration they could derive from evenly suspended attention, interpretation and empathy. Sigmund/Wulf/ had become an effective protagonist. He addressed himself to groups pointing out the dangers of violence, which could lose them the sympathy of the many non-europeans who for once stood solidly behind them.... He was looking beyond towards a new vision, a bond with [his] people in the rest of the world. ... And thus it was that this story, which was to have been about John the subject of a psychoanalytic study to be read by a limited number of scientists, became the story of John, the man, written to be read by everyone.

But let us refrain from too much optimism, however, and reserve judgment for such an expansive move. Nevertheless, I believe that a utopian possibility may be seen to be opened up within this particular socially situated analytic interaction.

\section{Silence Is the Crime: The Psychoanalyst as Torturer and the Institutional Politics of Denial}

The second story that I will turn to now concerns the ethical and political choice to act made by one particular psychoanalyst, Helena Besserman Vianna of Brazil. At great personal cost and danger to herself, she chose to speak out and to continue speaking out in the face of the explicit, concerted, and farreaching institutional efforts to uphold a politics of denial, namely the tacit protection of doctor and psychoanalytic training candidate Amilcar Lobo, who was part of a military torture squad (Chavafambira's nightmare vision incarnate). The story of the repetitions of institutional silencing was the specific subject of Besserman's book, Do Not Tell: The Politics of Psychoanalysis In the Face of Dictatorship and Torture, published in the original Portuguese in 1994, made available soon after in Spanish and French versions, but still not available in English. A review by Peter Hildebrand was published early on, however, in the Bulletin of the British Psychoanalytic Society, and in 2005, a special issue of 
the Psychoanalytic Review on "Politics and Psychoanalysis" allowed for substantial space for the story recounted in the book. This was also recorded in detail in Lucia Villela's article, appropriately entitled "The Chalice of Silence: The Case that Refuses to Go Away," which was published alongside lengthy responses of members of the IPA leadership involved in the events, namely Wallerstein and Etchegoyan. A very recent article in the journal Psychoanal$y$ sis and History also engages closely with Besserman's book in the context of a more general examination of the deployment of psychoanalysis under conditions of political repression, especially in Brazil (Rubin et al. 2016).

But let us now turn to the story that Besserman tells, which it is worth recounting again here, even though it will be impossible to do justice to its complexity. Besserman makes a point of de-centering the scandal of Lobo, the analyst-torturer, as an example of a specific case of the perversion of a profession, which like medicine is built on an ethics of trust (see Harris and Botticelli 2010). Rather, she places Lobo in a longer history of psychoanalytic institutional politics. Let us try to follow her story, the beginning of which she situates in 1930s Europe and the decision made by Ernest Jones with Freud's agreement to salvage the practice of psychoanalysis in Germany under Nazi rule. This involved tacitly supporting the continuous operation of the Berlin Psychoanalytic Society led by its Aryan members while their Jewish colleagues were forced out and persecuted. Werner Kemper was one such analyst who continued to work throughout the war; he was a collaborator and member of the Nazi Party rather than a secret resistant. In the immediate aftermath of the war, neither Kemper nor any of his German colleagues were asked to account for their activities (a reckoning would come later) (see Frosh 2005). In fact, Kemper reinvented himself as a militant Marxist, and along with Mark Burke, a British analyst who had been a major in the Royal Army medical corps, he was sent to Brazil by the International Psychoanalytic Association as a training analyst. Ideological and temperamental differences between the two led to a split within the Rio de Janeiro Society, which divided into Rio 1 (Kemper's group) and Rio 2 (Burke's). By the mid-1960s, both men had left Brazil.

In 1964, general Castello Branco, with the support of the United States, took power in Brazil, inaugurating a military dictatorship that lasted nearly twenty years. Like other places in the region, notably Argentina, the regime used tools of repression including violently crushing dissent, imprisonment, torture, and murder. It was in this context that Leo Cabernite, an analysand of Kemper with close ties to the military, acquired considerable institutional power within Rio 1. Between 1971 and 1974, he became a training analyst to 
Amilcar Lobo Moreira, a medical doctor who was also a torturer employed by the secret police. An underground newspaper, Voz Operaria, named Lobo as part of a government torture squad. In fact, his activities were an open secret. Helena Besserman Vianna forwarded this article together with a handwritten note to Marie Langer, herself a key left-wing figure in Latin America, for publication in the Argentinian journal Cuestionamos. Langer then forwarded both the article and the note to Serge Lebovici, then the president of IPA, demanding an investigation into the matter and that the IPA clarify its position; in other words, Langer demanded the IPA take sides. Instead, the article with the hand-written note was sent to Cabernite as Lobo's analyst. As a consequence of this, a government graphologist identified Besserman Vianna, who had also drawn attention to herself by publicly and scandalously asking Bion how he would respond to an analytic candidate who had "committed atrocities against others" during his famous Brazilian lecture tour (Bion 1980, 175). In effect, Besserman Vianna's choice to act, to speak out, to take sides, put her at risk. The IPA as an institution did not respond to Langer's demand. In fact, the institutional prevarications, many years of investigations, and ethical inquiries of one sort or another, were such that even in 2005, at the time of Villela's article, "the Lobo case and the events that followed have been the focus of splits and controversies that are partly solved, and then forgotten, and then repeated again" (Villela 2005, 806).

Derrida's "Geopsychoanalysis: '... and the Rest of the World," which was invoked at the beginning of this paper concerns itself above all with the act of naming. It was originally a talk delivered to a meeting of French and Latin American analysts in Paris at the invitation of Rene Major, a friend and ally of Besserman Vianna, who also wrote the preface to the French translation of Besserman Vianna's book. Derrida specifically addressed the IPA's need to formulate a neutral condemnation of human rights abuses. As the consensus statement put it, in "parallel with other international organizations, the IPA is aware of the violation of human rights occurring in certain regions of the world. ... The IPA equally condemns the violation of human rights, citizens, scientists, and of our colleagues in particular" (Major in Besserman 1996, 13, my translation). As Major puts it,

This declaration neglects the properly symbolic inscription of the violation; effaces through its formal abstraction the reach it could have coming as it does from an international organization legitimated by Freud's thought ... it annuls the act of nomination (which links the 
name of a country to proper names to a particular politics), all of which is guarantor of an ethics of speech. Furthermore, its corporate nature weakens or corrupts its universalist intentions. (13)

In other words it is inaction, not taking sides, turning away from a specific situation, which is detrimental to the psychoanalytic project, and which thus finds itself curiously bracketed off from the world in the name of a misunderstood ethics of neutrality.

Although the truth about Lobo became officially known by the early 1980s, it is ironic as well as detrimental to her safety, that for years the only one named was Besserman Vianna herself. It is fitting to be reminded here of the title of the book in which she made the story public: Do Not Tell. This can be read in the context of the events that are recounted in it as a perverse interpretation of the ethical stand that protects the boundaries and privacy of the analytic encounter. Lobo himself went public and published an account of his activities in 1989. But as far as the IPA and Cabernite's role in actively dissimulating the activities of Lobo, it fell to Horacio Etchegoyan to initiate an ethical enquiry, which began as late as 1994 and which eventually led to Cabernite's exclusion from the IPA (Villela 2005; Rubin et al. 2016).

Commenting on the role of psychoanalysis, Villela $(2005,814-15)$ states:

Two of the main ethical problems faced by analysts are those of confidentiality and of neutrality. That is not the problem we are discussing here. An analyst cannot ever denounce a patient and break the confidentiality of the analytic relationship, and Dr. Cabernite would have been perfectly within his rights and within analytic ethics if he had limited his actions to helping his analysand confront his own existing doubts about his job and to seeing him through this tragically destructive part of his life. However, it is not acceptable for the president of an analytic society, or for any analyst, to permit the acceptance, let alone the training, of a candidate who is sworn to alleviate human suffering and instead contributes to the imposing of physical or psychological pain in the interrogation of any human being, including prisoners, whether criminal or political.

When Helena Besserman Vianna spoke at the Estates General of Psychoanalysis conference held in Paris in the summer of 2000, one of her last public appearances before her death in early 2002, she retold the story of her in- 
volvement with the Lobo case. In her paper she insisted, as she did in her book, on the institutional filiations of silence and transgression at work, and on the chain that linked Kemper to Lobo. She called, in an impassioned way, for psychoanalysis' active political engagement; neutrality and silence were not an option, she said, especially for psychoanalysts, since separation from the social and political arena was not possible, it was worst than a mistake, it was a waste ("gaspillage" was the word she used) (Besserman 2000). In other words, to separate out the private was one thing, but to then forget about the public sphere was something of a different order all together. One has to take responsibility for failing to act and for the consequences of that failure.

In a later interview given in 1996, Lobo again acknowledged that he did work with military teams in the interrogation of prisoners, but justified his actions by saying that his job was mostly keeping the prisoners alive, and so it was within the boundaries of medical ethics. Responding to Helena Vianna's criticism of his actions, to her accusations that he had no shame for acts committed or witnessed, he wrote, "she seems to forget that Man has used torture and murder for thousands of years, ever since he organized in societies. Only a very short time ago, the Inquisition tortured and killed countless Jews, and a little over forty years ago, the German Nazi regime proceeded in the same manner. This is thus man in his total mental structure, and I am not ashamed to be one of them" (quoted in Villela 2005, 823).

The clinical and political meanings of "having no shame" are one thing and quite separate from a theorization of the aggressive instinct, and it may be worth here invoking Freud's brilliant analysis of social violence in Civilisation and Its Discontents which argues:

[T] hat men are not gentle creatures who want to be loved, and who at the most can defend themselves if they are attacked; they are, on the contrary, creatures among whose instinctual endowments is to be reckoned a powerful share of aggressiveness. As a result, their neighbour is for them not only a potential helper or sexual object, but also someone who tempts them to satisfy their aggressiveness on him, to exploit his capacity for work without compensation, to use him sexually without his consent, to seize his possessions, to humiliate him, to cause him pain, to torture and to kill him. Homo homini lupus. Who in the face of all his experience of life and of history, will have the courage to dispute this assertion? (Freud 1929, 111) 
After dozens of re-readings, this passage still takes my breath away. Freud succeeds in troubling certainties on two levels. He weaves together not only individual and group behavior-the responsibility for violence against the other operates clearly on both levels - but also the realm of material and psychic fact. There is no doubt whatsoever that human beings do rape, enslave, torture, and kill one another, but this violence also operates at the level of desire and fantasy, where the subject and object of violence exist in interdependent complementarity. The neighbor, Freud notes, tempts us to satisfy our aggressiveness. We all have a neighbor; we are all somebody else's neighbor.

This is not an invitation to follow our desire without shame, but rather to understand precisely the responsibilities of interconnectedness. The wager of psychoanalysis is that silence and turning away have consequences, personal as well as institutional.

I am aware that what I present here does not lend itself to a conclusion, but rather to continued questioning. I have invoked two specific moments in the history of psychoanalysis, each of which in its own way places a demand towards the opening up or the extension to the remit of psychoanalysis. This extension may involve the recognition of the fundamental sociality and historical situatedness of our subjectivity, which by definition would move "the rest of the world" out of the margins of institutional disavowal. But recognition in itself is not sufficient, but it does involve persistently striving for a multiplicity of dialogues, not only the dialogue of patient and analyst, or those across many branches of the fragmented world of psychoanalysis, but also between psychoanalysis and other disciplines and practices from which it may learn. And in such a dialogue, it would, of course, make its own modest or immodest contribution. Such an extension of psychoanalysis would, at times, necessarily include the commitment to speak out, take sides, and act when the situation demands it, as it did in the two examples above, outside institutions, case by case, act by act.

\section{REFERENCES}

Besserman, Vianna Helena. 1997. Politique de la psychoanalyse face à la dictature et à la torture: N'en parlez à personne. Paris: l'Harmattan.

Bion, Wilfrid. 1990. Brazilian Lectures. London: Karnac.

Borossa, Julia. 2007. "Narcissistic Wounds, Race and Racism: Frantz Fanon's Critical Engagement with Psychoanalysis." In Narcissism: A Critical Reader, edited by Julia Borossa, 113-126. London: Karnac. 
Danto, Elizabeth A. 2005. Freud's Free Clinics: Psychoanalysis and Social Justice 19181938. New York: Columbia University Press.

Derrida, Jacques. 1991. "Geopsychoanalysis: '...and the Rest of the World.” Translated by D. Nicolson-Smith. American Imago 48, no. 2: 199-231.

Etchegoyan, Horacio. 2005. “Commentary on Lucia Villela's and Bernard Rubin's Papers." Psychoanalytic Review 92, no. 6: 857-63.

Freud, Sigmund. (1929) 1930. “Civilisation and Its Discontents.” In The Standard Edition of the Complete Psychological Works of Sigmund Freud. Vol. XXI. Edited by James Strachey. London: Hogarth.

Frosh, Stephen. 2005. Hate and the Jewish Science: Antisemitism, Nazism, and Psychoanalysis. London: Palgrave.

_. 2007. "Facing Political Truths." Psychotherapy and Politics International 5, no. 1: $29-36$.

Harris, Adrienne, and Steven Botticelli, eds. 2010. First Do No Harm: The Paradoxical Encounters of Psychoanalysis, Warmaking, and Resistance. New York and London: Routledge.

Hildebrand, Peter. 1999. “The Cabernite Affair." Bulletin of the British Psychoanalytical Society (January): 30-34.

La Capra, Dominick. 1998. History and Memory after Auschwitz. Ithaca and London: Cornell University Press.

Major, René. 1997. "Préface et lettre ouverte." In Politique de la psychoanalyse face à la dictature et à la torture N'en parlez à personne. ., 5-26. Paris: l'Harmattan.

Rubin, Aline, Belinda Mandelbaum, and Stephen Frosh. 2016. "No Memory, No Desire: Psychoanalysis in Brazil during Repressive Times.” Psychoanalysis and History 18, no. 1: 93-118.

Sachs, Wulf. 1933. “The Insane Native: An Introduction to a Psychoanalytic Study." The South African Journal of Science 30: 706-13.

_ . (1947) 1968. Black Anger. New York: Greenwood Press.

__ (1937) 1996. Black Hamlet. Introduction by Saul Dubow and Jacqueline Rose. Baltimore and London: Johns Hopkins University Press.

Segal, Hanna. 1997. "Silence Is the Real Crime." In Psychoanalysis, Literature and War: Papers, 1972-1995, edited by Hanna Segal, 117-28. London: Karnac.

Vaughan, Meghan. 1991. Curing Their Ills: Colonial Power and African Illness. Cambridge: Polity.

Villela, Lucia. 2005. "The Chalice of Silence and the Case that Refuses to Go Away." Psychoanalytic Review 92, no. 6: 807-28.

Wallerstein, Robert. 2005. “The Lobo-Cabernite Affair Revisited: And Commentary on Articles by Villela and Rubin.” Psychoanalytic Review 92, no. 2: 839-56. 



\title{
How Ideology Shaped Psychology in Times of Wars and after Wars
}

\author{
Gordana Jovanović
}

The main aim of this chapter, seen within the general framework of the relationship of politics and psychology, is to reconstruct prevailing ideological underpinnings of developments in psychology in the twentieth century. Given the fact that the twentieth century was substantially determined by two world wars and the Cold War, special attention will be given to the influence of war ideologies on psychology as discipline and profession. As far as the history of psychology is concerned, a socio-genetic approach will be assumed, meaning that the emergence of psychology and its subdisciplines is understood as a response to the needs of modern society organized on new assumptions. From such a perspective, psychology is seen as playing an important role in modern ideological projects.

The focus of this chapter will be on developments related to the two world wars and the Cold War, but developments in cultural psychology in the 1990s will be also addressed. Relying on critical interpretations of cognitive psychology as ideology of subjectivism and individualism as put forward by Edward Sampson, it will be asked whether cultural psychology, which has been developed as an attempt to realize promises not fulfilled by the cognitive revolution (Jerome Bruner), has sufficient means to overcome ideological shortcomings pertaining to cognitive psychology and psychology in general. While cultural psychology transcends the prevailing epistemological and ideological individuo-centrism of cognitive psychology, it remains cognition centered, even if cognition is considered to be symbolically mediated. The 
consequences of that centration affect not just conceptualizations of the epistemic subject (cognition as a self-generative though mediated process); they also make cultural psychology myopic as far as insights into social conditions of possibility of meaning-making processes and interpretation are concerned.

In general, this essay will argue that these forms of centration and myopia reveal the ideological functions of cultural psychology as a discourse that positions culture within the taken for granted societal order and addresses cultural transformation rather than societal change. Such an interpretation is justified also when broadly applied to mainstream psychology.

\section{Approaching Psychology and Politics}

With regard to the task of looking for relationships between psychology and politics, different approaches may be used, depending on the conceptions of relationship and on general understanding of science, politics, society, and history.

Biographical approaches, which examine the influence of political events on the professional career or life of psychologists, could potentially have many advantages, as their subject is relatively easy to define and data is generally available. However, although biography appears easy at first, it is clear that the burden of selection and interpretation cannot be avoided, even when describing a single case.

Take, for example, the well-known biography The Life and Work of Sigmund Freud by Ernest Jones. This biography is also a political biography, or more generally, a piece of psychoanalysis' political history, which makes it even more significant. Jones's famous biography of Freud contains many false or misleading statements and conceals other information, e.g., when Jones stated that Wilhelm Reich voluntarily resigned his membership in the German Psychoanalytic Society (DPG) at the Congress at Lucerne in 1934, while Reich was in fact secretly expelled a year before the congress: "It was on this occasion that Wilhelm Reich resigned from the Association" (Jones 1977, 622). Jones had followers among historians of psychoanalysis who repeated his claims: "Reich believed he has been expelled from the International Psychoanalytic Association (1934), whereas to Jones it seemed a resignation" (Roazen 1976, 505). There were published reports available in which Reich confirmed that he would never have voluntarily resigned from the psychoanalytic society, and his stance should come as no surprise, as psychoanalyst 
Eva Rosenfeld posited: "They could not resign voluntarily because too high a degree of masochism would be involved, as though they had voluntarily become their own executioners" (quoted in Lothane 2001, 199).

But all this has not prevented Ernest Jones from falsifying the facts, and beyond that, collaborating with the Aryanized German Psychoanalytic Society and its officers:

But even as one should not judge people and events from 1933 to 1939 only in the light of the knowledge of later developments, it is still astounding how Freud and others succumbed to their wishful impulses and illusions in striking shady deals with the devil and how the Jewish members of the IPA were disposed of as demanded by the Nazis. Perhaps Freud was too sick and too old to hear the warnings of Sandor Rado and Eitingon in Berlin and leave Vienna. Perhaps he listened more to Ernest Jones, his Gentile advisor, mover and shaker, heir to the former Gentile Carl Jung, the conformist Jones who had no problems negotiating with the "Aryan" representatives of German Psychoanalysis, Boehm and Müller Braunschweig. (Lothane 2001, 215)

Even though Jones wrote his biography of Freud after World War II, he must have been familiar with Freud's attitude against biography. Jones $(1977,630)$ himself quoted Freud's warnings: "Whoever undertakes to write a biography, binds himself to lying, to concealment, to hypocrisy, to flummery, and even to hiding his own lack of understanding, since biographical material is not to be had and if it were it could not be used. Truth is not accessible, mankind does not deserve it...."

I have discussed that particular case extensively elsewhere (Jovanović 2014), but I think it is also very instructive for the present study. Evidently, the influence of political events is always mediated in different ways. But before examining any mediation, it is important to bear in mind that political events are not entities that exist independently from the ways people understand them; on the contrary, their very existence is relative to the observer, as is any other social fact in a socially created reality. John Searle $(1996,12)$ argued in favor of the specificity of social facts:

But from our standpoint, the standpoint of beings who are not gods but are inside the world that includes us as active agents, we need to distinguish those true statements we make that attribute features to the world 
that exist quite independently of any attitude or stances we take, and those statements that attribute features that exist only relative to our interests, attitudes, stances, purposes, etc.

Additionally, in regard to the fundamental dependency of social and, for that matter, political facts on the attitudes and interests of human agents, the case in question is open to, or rather, it invites psychoanalytic interpretation. Indeed, what is the function and meaning of a reversal that asserts the opposite, that is, how did Reich's exclusion become his supposed resignation? "In that constellation it seems as if Reich played a role of psychoanalysis, which brought the repressed to the light and thus provoked defense mechanisms. The problem seems to be that involved psychoanalysts were not aware of that and were not interested in making it conscious" (Jovanović 2014, 411).

The reconstruction of just a small piece of a biographical account that illuminates the relationship of psychology and politics has shown how difficult it might be to describe an event and how politicized descriptions may be. Even more important is the need to examine the relationship between psychology and politics on a more abstract and mediated level. Surely, this is an epistemological challenge, but it is no less political. However, the benefits outweigh the risks of such an intellectual endeavor.

\section{The History of Psychology in a Socio-Historical Key}

I approach the history of psychology from a socio-cultural perspective as exemplified by the scholarship of Danziger's Naming the Mind (1997), Foucault's The History of Sexuality (1978) and Technologies of the Self (1988), Jaeger and Staeuble's Die gesellschaftliche Genese der Psychologie (1978), and Rose's The Psychological Complex (1985) and Inventing Ourselves (1998).

A socio-historical approach to psychology and the history of psychology positions modernity as the birthplace of psychology, beyond the chronological fact that psychology was established in the modern era. Modernity as a new epoch was founded on new principles: human self-determination; individualism; models of instrumental computational rationality; new emotional economy as part of a pattern of civilized behavior; and a reflexive attitude. The new position of the individual opened space for the acquisition of new experiences in the human-made world: that is, society and individuals. Psychology and its subdisciplines constructed their subject matter from these new experi- 
ences. Therefore, these historical achievements and the conditions that shaped them are part of the history of psychology. In fact, Kenneth Gergen (1973, 319) argued several decades ago that "social psychological research is primarily the systematic study of contemporary history," but I would argue that the same applies to psychology in general.

But references to history are not made simply for the sake of acknowledging the past. Historical reflexivity is a tool that shapes approaches to any phenomena, including contemporary ones, as it makes them visible at the very moment of their development and demonstrates in that way that they are entities possibly open to further changes in the future. Historical reflexivity can be, and perhaps should be, applied to history itself, and specifically historical accounts. An example highly relevant to a political and ideological reading of psychology and its history is Stephen Toulmin's revised account of modernity. Contrary to the standard account of the origins of modernity in Cartesian rationalism and natural sciences, Toulmin discovered a valuable agenda of modernity in the work of Renaissance' humanists:

The contrast between the practical modesty and the intellectual freedom of Renaissance humanism, and the theoretical ambitions and intellectual constraints of $17^{\text {th }}$-century rationalism plays a central part in our revised narrative of the origins of Modernity. By taking the origin of Modernity back to the 1500s, we are freed from the emphasis on Galileo's and Descartes' unique rationality, which was a feature of the standard account in the 1920s and 30s. The opening gambit of modern philosophy becomes not the decontextualised rationalism of Descartes' Discourse and Meditations, but Montaigne's restatement of classical skepticism...." (Toulmin 1992, 42)

In other contexts too, an initial choice mobilized forces that reinforced certain issues that were selected and marginalized or repressed those that were not. Quite striking is the fact that even seemingly opposite forces can work toward the same goal. A very good example in the given context is the role of Locke's empiricism in modern development. It might be surprising that both the rationalist Descartes and the empiricist Locke contribute to the same model of modern development. They both share one of the basic tenets of mainstream modernity: strong individuo-centrism. In Descartes's rationalist philosophy, knowledge is constituted in the self-conscious, thinking individual mind: "to embrace in my judgment only what presented itself to my mind so clearly 
and distinctly that I had no occasion to doubt it" (Descartes [1637] 1978, 20). In Locke, intellect operates on material provided by senses; all ideas and knowledge arise from experience, Locke assures us in An Essay Concerning Human Understanding (1690). Both Locke's empiricism and associationism are recognized as important contributions to the pre-history of psychology (Heidbreder [1933] 1961; Murphy 1960; Woodworth and Sheehan [1931] 1975). In new histories of psychology, Locke remains an important figure: "In proposing that human knowledge comes through sense experience, Locke laid the foundation for both empirical philosophy and, much later, the human sciences, including Psychology" (Pickren and Rutherford 2010, 6).

One important feature of the modern worldview is also a mechanical picture of the world, which is a consequence of processes taking place in different domains. Nature was no longer seen as imbued with purpose; rather, it functioned as a mechanical device (the clock metaphor was widely used). Simultaneously, there were also changes in the structure of human labor, which led to the development of intensive manufacture and later on industrial production (Borkenau [1934] 1980).

Kurt Danziger reminds us that it is very important to take into account a homology among the representations of the physical, social, and mental worlds. Association of elements was a common explanatory principle.

The introduction and popularization of the term "association of ideas" involved a metaphorical transfer of meaning from the social to the psychological level. Just as societies were considered to be formed by the combination of separate and independent persons, so individual minds could be thought of as formed by the association of separate mental elements.... What classical associationism accomplished was the establishment of a metaphorical homology among three levels of discourse, dealing respectively with the structure of society, the structure of the physical world, and the structure of the human mind. (Danziger 1994, 347)

Such conceptions of human world and mind are related to an understanding of knowledge, which Charles Taylor $(1995,12)$ called representational knowledge: "as depictions that are separately identifiable from what they are of." The next step, then, is thinking, which is identified with formal operations conducted on depictions, and the computer is welcomed as a model of the mind. Thus, there is a long developmental line which bridges domains and centuries. 
In the seventeenth century, a new mechanical view of the nature was elaborated and it grounded emerging (new) natural sciences. With an instrumental attitude toward nature and a mechanical understanding of it, modernity adopted control over nature as part of its agenda. In philosophy, Descartes ([1701] 1971, 153) saw it was necessary to formulate new formal rules for directing the mind in the investigation of truth: Regulae ad directionem ingenii. The first rule defines the aim: gaining certain and true knowledge. But this was also an eliminative criterion, as the second rule is "We must occupy ourselves only with those objects that our intellectual powers appear competent to know certainly and indubitably."

Even though the Regulae ad directionem ingenii were published only as Opera posthuma, the same spirit permeated, more or less explicitly, other works by Descartes, and shaped a model of formal, decontextualized rationality as described by Toulmin (1992, 200):

Whatever sorts of problem one faced, there was a supposedly unique procedure for arriving at the correct solution. That procedure could be recognized only by cutting away the inessentials, and identifying the abstract core of "clear and distinct" concepts needed for its solution. Unfortunately, little in human life lends itself fully to the lucid, tidy analysis of Euclid's geometry or Descartes' physics.

And Descartes was not alone in his attempt to justify his quest for certainty. "Growing up in a Germany traumatized by the Thirty Years War, for instance, Leibniz insisted more strictly than the Newtonians on the need for the foundation of philosophy to be both mathematically and metaphysically 'provable"' (Toulmin 1992, 140).

What is indeed striking is that Toulmin $(1992,160)$ sees a line leading from this seventeenth-century model of modernity and rationality to the wars that defined the twentieth century: "The Second World War, then, represented the culmination of social and historical processes that began in the 1650s, with the creation of the Modern era."

Given the origins of such a model of formal rationality in the aftermath of the religious wars of the seventeenth century, which were understood as initiating the search for certainty, at first glance, it might look strange that such a search for certainty, supported by the development of a rational attainment method, ended up in the mass destruction of life itself. But if we bear in mind that such a model began by isolating rationality from the lived context, 
it should come as no surprise that isolation and alienation from life eventually led to the destruction of life. What is indeed surprising, however, is that responses to the disaster of war repeated an earlier pattern, the "move away from the historical, concrete, or psychological, toward the formal, abstract, or logical" (Toulmin 1992, 153).

\section{Psychology and War}

As far as psychology is concerned, it has not only adopted the assumptions, but also the main achievements of the modern era-its individualism, dominant model of scientific thought, goals of control and prediction. There is a close link between psychology and war as well. Within the framework of Toulmin's revised narrative of modernity, that link is actually a logical consequence. Even though the broader framework is barely reflected in psychology, it is important to bear it in mind in order to understand the deeper motivation that sustained the mutually fruitful relationship between psychology and war.

One telling example is World War I's substantial influence on the development of psychology. The war proved beneficial for the development of quantitative psychological technology; testing and measurement models of psychological scientific rationality are psychological exemplifications of the formal, decontextualized rationality whose genesis Toulmin traced back to the seventeenth century. Even though practical needs conditioned by war were a powerful justification for identifying methods that could offer viable solutions on a grand scale (millions of soldiers were given intelligence and personality test), tests failed to provide reliable predictions. Nevertheless, they were considered to prove the scientific status of psychology now that it had demonstrated the possibility of measuring complex psychic phenomena, even the personality, which for so long had been understood as resistant to both measurement and discursively articulated accounts. Tests have indeed become a powerful psychological technology. Beyond that, they started to influence the general public's attitudes and ways of thinking, inducing the search for self-improvement techniques, which gained so much momentum that many movements for psychological self-improvement emerged.

However, there are other links between psychology and war, which may also be interpreted in a very affirmative, humanist way. The British Psychological Society (BPS) intended "to pay tribute to those whose contributions helped to shape our discipline" during World War I. 
The centenary of the First World War provides the Society with an opportunity to commemorate a watershed in the discipline of psychology. The war marked a turning point in the development of many different areas of psychology. ... In 2015 we will be commemorating 100 years since "shell-shock" was first described in The Lancet. The Society will recognise the contribution of C. S. Myers, as well as exploring the latest research into PTSD and combat stress today. ${ }^{1}$

It is interesting to compare the importance given by the British Psychological Society to the context of World War I for the identification and recognition of shell shock as a psychological wartime construct, to other interpretations of the very same phenomenon. In an article published in the Journal of the History of Medicine two years before the centenary, it is argued that "shell shock did not constitute a fundamental rupture in the dominant paradigms of early twentiethcentury psychological medicine, but was part of a longer process of gradual and uneven shifts in thought and practice" (Loughran 2012, 109). But why is then the British Psychological Society inclined to argue for such a strong link between World War I and the recognition of the psychological consequences of combat, which then shaped the shell shock construct, simultaneously constructing the war as a watershed in the development of psychology? This is a crucial question; without asking such questions, the ideological assumptions and implications of psychology will remain concealed though they remain in operation.

It should be added that the Vietnam War and its consequences, including the antiwar movements and other changes in existing power structures and thinking patterns also proved fruitful for the construction and professional and social recognition and explanation of some new psycho-pathological phenomena. It is because of the "nervous" breakdowns of American soldiers after their return from Vietnam that a delayed traumatic syndrome was identified and, in 1980, officially recognized by the American Psychiatric Association as post-traumatic stress disorder (PTSD), states Edgar Jones:

Although there is no direct chain of events from World War One through to the recognition of PTSD in 1980, the shell shock episode had focused unparalleled attention to the issue of traumatic illness.

${ }^{1}$ British Psychological Society, http://www.bps.org.uk/psychology-public/sharingour-science/centenary-world-war-i/centenary-world-war-i, retrieved on October 20, 2015. 
Never before had so many soldiers suffered from psychological disorder. Furthermore, their illness could not be explained by pre-war theories of degeneration, heredity or the side effects of infectious disease. Neurologists, general physicians and even surgeons, doctors who before 1914 would not have shown any interest in psychiatry, were drawn to shellshock. By bringing new ideas to the discipline, it gave a fresh impetus to the search for psychological understanding and, in this sense, PTSD can be viewed as a progeny of World War One. Whilst today we are better equipped to diagnose and treat psychological trauma, we seem no further forward in preventing the conflicts that are the cause of these illnesses. (Jones 2014)

I would argue that individual PTSD could be interpreted as individualized forms of a post-traumatic situation at the national level: a superpower lost a war against a third-world country, it lost a war waged also to prevent the spread of communism, and the war ended in victory for a communist enemy. But that individualization and psychologization of a dramatic collective experience could also have a defensive function: by focusing on individual psychological problems and mobilizing necessary resources to deal with these problems, it conceals the prior decisions and broader context that led to the war. Thus, the very possibility of drawing attention to the delayed consequences of war trauma was actually the achievement of antiwar activism. There were also changes in aetiological theory, where originally primacy was given to traumatic exposure. But in spite of that, PTSD stands mostly for individual suffering. Its diagnostic and therapeutic use is estranged from social and political critique. Obviously, no advancement in trauma expertise has prevented further wars. New wars generate new PTSDs and the question to be posed is: what might be the next interpretive turn in the conceptualization of trauma and its origins that would be capable of mobilizing effective social and political critique?

Wars affected development of psychology in many other ways, and not just by generating new human experiences, which then found their way into psychological subject matter. There were other, more indirect influences, which also affected organizational forms of psychology, and consequently the social position of psychology. Thus, James Capshew in his book Psychologists on the March pointed out that World War II was a turning point in the history of American psychology. He showed that there were shifts in all domains: occupational, research, teaching, which all had in common efforts to make psychology and psychologists relevant to national needs. Service to national 
needs became inscribed into the self-understanding of the psychological profession. The practical, or more precisely military demands made on psychologists during the war continued to be made and followed after the war, and they eventually transformed psychology from an academic to a consultative discipline, whereby psychologists offered different services to different categories of clients. Thus, Capshew (1986) argued that World War II acted as a catalyst for the professionalization of applied psychology, fundamentally altering the relationship between science and practice in the discipline. In sum, the shift to practical services has shaped the more technological self-understanding of psychology.

The reference to national needs still operates as a justification for the involvement of American psychologists in problematic endeavors (Guantanamo, for example). This has provoked many protests within the American Psychological Association itself, which was forced to finally take action to approve new ethical rules which bar psychologists from involvement in any national security interrogations.

General Kelly's order is the latest fallout after years of recriminations in the profession for the crucial role that psychologists played in the post-9/11 programs of harsh interrogation created by the C.I.A. and the Pentagon. The psychologists' involvement in the interrogations enabled the Justice Department in the George W. Bush administration to issue secret legal opinions that declared that the C.I.A.s so-called enhanced interrogation program was legal, in part because health professionals were monitoring it to make sure that it was safe and that it did not constitute torture.

Psychologists were more involved than psychiatrists in the Bushera interrogation programs at the C.I.A. and the Pentagon, at least in part because Bush administration officials believed that officials at the American Psychological Association were more supportive of the role played by psychologists in interrogations. By contrast, Bush officials believed that officials at the American Psychiatric Association, which had tougher ethics rules, were not comfortable with the involvement of psychiatrists. (Risen 2015)

Although it is not possible to imagine a more direct political instrumentalization of psychology, dominant political ideology influenced psychology in many indirect ways, even at the conceptual level. It is difficult to trace such 
influences in different forms of psychology, which, at a glance, appear purely scientific. Cognitive psychology is a good example of this. Tracing the more hidden and mediated ways of political saturation poses a significant challenge, and the very fact that there may be latent political relevance is, in itself, politically relevant.

Again, it would be helpful to situate cognitive psychology, or the cognitive revolution, within the history of psychology. It was a kind of "return of the repressed," a return of subjectivity repressed by behaviorism due to its identification of the scientific with the external existence of the research object. In the view of one of the founders of cognitive revolution, Jerome Bruner $(1990,1)$,

That revolution was intended to bring "mind" back into the human sciences after a long cold winter of objectivism ... at least in my view that revolution has now been diverted into issues that are marginal to the impulse that brought it into being. Indeed it has been technicized in a manner that even undermines that original impulse... Some critics, perhaps unkindly, even argue that the new cognitive science, the child of revolution, has gained its technical successes at the price of dehumanizing the very concept of mind it had sought to re-establish in psychology, and that it has thereby estranged much of psychology from the other human sciences and humanities.

The link to technological thinking in psychology has been quickly re-established, even in the academic domain. But in support of critics of the technologization of cognition, it is worthwhile to remember warnings put forward by Stephen Toulmin: "Unfortunately, little in human life lends itself fully to the lucid, tidy analysis of Euclid's geometry or Descartes' physics" (Toulmin 1992, 200).

Cognitive psychology has features that are more deeply obscured and deserve more criticism beyond its technicalization. Edward Sampson in American Psychologists in 1981 analyzed cognitive psychology as an ideology of individualism and social conformism.

... the cognitive perspective in psychology, by virtue of the primacy it gives to the individual knower and to subjective determinants of behavior, and though appearing to reveal something fundamental and invariant about the human mind, represents a set of values and interests 
that reproduce the existing nature of the social order.... The issue of values also raises serious questions about the nature of our psychological science itself. (Sampson 1981, 730)

Within the framework of analysis of the relationship between war and psychology, a critical reading of psychological theories of conflicts would be most helpful. These theories, mostly developed by Morton Deutsch (1973), translate social conflicts into cognitive failures: misperceptions or misunderstandings. Thus, proposed resolutions exist in the same cognitive domain. Sampson, relying on Michael Billig's critique of these theories, claims that such an approach "serves primarily ideological functions by eliminating from our analysis the contradictions that exist among groups in the real world" (Sampson 1981, 737).

False translations at the cognitive level itself are also targets of Bruner's critique of cognitive psychology; instead of investigating meaning-making processes, cognitive psychology was occupied with information processing (Bruner, 1990). Evidently, the computational model of cognition could be easily combined with overall technical interests. In sum, the cognitive revolution failed, and the consequences of this failure enriched the existing picture of psychology in which technology played a central role.

In the broader socio-political context of the postwar period, specifically the Cold War, there was a strong impulse to encourage rationality debates. As documented in the book How Reason Almost Lost Its Mind, the Cold War proved fruitful for the development of academic psychology. Once again, war, this time a "cold war," shaped psychology. However, its development privileged a specific model of formal, algorithmic skeleton rationality of homo oeconomicus in contrast to a bounded, adapted rationality. In such a formal model of rationality, there was an expectation that this form of rationality could help saving humanity from annihilation. It might look strange that in the context of the Cold War, which was an ideological war, that is, war for meanings, a formal, algorithmic rationality was understood as a proper means to deal with this type of conflict. This was the very same strategy used in the seventeenth century and after World War I.

With the end of the Cold War, which people hoped would bring an end to all wars, rationality debates in the form they were known and practiced during the Cold War also disappeared. Unfortunately, war itself did not.

It is under such conditions, i.e., after the Cold War, that a new attempt has been made to bring meaning-making processes back to psychology by 
launching cultural psychology programs, or more precisely, encouraging the renaissance of cultural psychology as older programs envisaged back in the second half of the nineteenth century and at the beginning of the twentieth century were forgotten or marginalized for decades. For example, even though Wilhelm Wundt is considered the father of psychology, his Völkerpsychologie (Wundt 1900-1920), which could be understood as a kind of cultural psychology, was forgotten for years (Jovanović 2019). Or Dilthey's verstehende Psychologie (understanding psychology) (Dilthey 1894) was not given a place in the history of psychology. However, Richard Shweder announced in 1991: "A discipline is emerging called cultural psychology." He went on:

Cultural psychology is the study of the way cultural traditions and social practices regulate, express, and transform the human psyche.... Cultural psychology is the study of the ways subject and object, self and other, psyche and culture, person and context, figure and ground, practitioner and practice, live together, require each other, and dynamically, dialectically and jointly make each other up. (Shweder 1991, 73)

Cultural psychology is evidently a program for overcoming psychological individualism, which is one of the primary vehicles of dominant political ideology of liberalism.

However, it would be challenging to ask whether cultural psychology has overcome the ideological pitfalls of cognitivism. Has cultural psychology remained prone to cognitivism (without individualism)? Is cultural psychology equipped with sufficient tools to reach all the levels of meaning making, including the possibilities for meaning making and not just methods of meaning making? These tools cannot be provided by cultural means alone; societal structures must be included, and they are not interchangeable with culture.

In regard to the above issues, I would argue that cultural psychology has maintained and carried forward the legacy of other psychological orientations as far as a turn away from societal production processes is concerned. With a pars pro toto attitude and conceptual and theoretical marginalization and repression of societal production processes, cultural psychology can be useful-as an a-cultural psychology used to be-for furthering national political needs. Indeed, it has been when it has offered consultative services in contemporary military conflicts.

Psychology's ability to avoid or escape a new cycle of political instrumentalization poses a real challenge. Regrettably enough, it was a standard 
account of modernity based on individualism, rationality, and the quest for certainty that prevailed both historically and theoretically, and it was also this understanding of modernity that shaped the development of the (social) sciences including mainstream psychology. That link can be most easily recognized in the cognitive revolution in psychology, although other psychological orientations share many of the attributes of modernity.

The historical reconstruction provided here has demonstrated that wars generated strong turns toward that which is unified, formal, certain, and pure and away from the oral, particular, timely, plural, and polisemantic. But there were times when these latter features of the human experience were acknowledged. This is worth remembering. It is also worth trying to draw the attention of psychology to them so that psychology is capable of grasping and respecting the lived experience of humanity.

\section{REFERENCES}

Borkenau, Franz. (1934) 1980. Der Übergang vom feudalen zum bürgerlichen Weltbild. Studien zur Geschichte der Philosophie der Manufakturperiode. Darmstadt: Wissenschaftliche Buchgesellschaft.

Bruner, Jerome. 1990. Acts of Meaning. Cambridge and London: Harvard University Press.

Capshew, James. 1999. Psychologists on the March: Science, Practice, and Professional Identity in America, 1929-1969. Cambridge: Cambridge University Press.

Danziger, Kurt. 1994. "Generative Metaphor and the History of Psychological Discourse." In Metaphors in the History of Psychology, edited by David E. Leary, 33156. Cambridge: Cambridge University Press.

- 1997. Naming the Mind: How Psychology Found Its Language. London: Sage.

Descartes, René. (1637) 1978. “Discourse on the Method." In Philosophical Writings, edited by Elizabeth Anscombe and Peter Thomas Geach, 5-57. Indianapolis: Bobbs-Merrill Educational Publishing.

_ _ (1701) 1978. "Rules for the Direction of the Mind." In Philosophical Writings, edited by Elizabeth Anscombe and Peter Thomas Geach, 151-80. Indianapolis: Bobbs-Merrill Educational Publishing.

Deutsch, Morton. 1973. The Resolution of Conflict: Constructive and Destructive Processes. New Haven: Yale University Press.

Dilthey, Wilhelm. 1894. "Ideen zu einer beschreibenden und zergliedernden Psychologie." In Gesammelte Schriften 5, 141-249. Stuttgart: B.G. Teubner \& Göttingen: Vandenhoeck \& Ruprecht.

Erickson, Paul, Judy Klein, Lorraine Daston, Rebecca Lemov, Thomas Sturm, and Michael D. Gordin. 2013. How Reason Almost Lost Its Mind: The Strange Career of Cold War Rationality. Chicago and London: The Chicago University Press. 
Foucault, Michel. 1978. History of Sexuality. Vol. 1. New York: Pantheon.

- 1988. Technologies of the Self. London: Tavistock Publications.

Gergen, Kenneth. 1973. "Social Psychology as History." Journal of Personality and Social Psychology 26, no. 2: 309-20.

Heidbreder, Edna. (1933) 1961. Seven Psychologies. Englewood Cliffs: Prentice Hall.

Jaeger, Siegfried, and Irmingard Staeuble. 1978. Die gesellschaftliche Genese der Psychologie. Frankfurt: Campus.

Jones, Edgar. 2014. "Psychological Wounds of Conflict: The Impact of World War One." Fair Observer, August 19. Available at http://www.fairobserver.com/region/north_ america/psychological-wounds-of-conflict-the-impact-of-world-war-one-71084, retrieved February 20, 2016.

Jones, Ernest. 1977. The Life and Work of Sigmund Freud. Harmondsworth: Penguin Books.

Jovanović, Gordana. 2014. "Ein Beitrag zur politischen Geschichte. Deutsch-skandinavische Übergänge am Beispiel Wilhelm Reichs.” In Influx. Der deutsch-skandinavische Kulturaustausch um 1900, edited by Søren Fauth and Gísli Magnússon, 381-413. Würzburg: Königshausen \& Neumann.

- 2019. "The Repression of Cultural Psychology in the History of Psychology." In The Challenges of Cultural Psychology: Historical Legacies and Future Responsibilities, edited by Gordana Jovanović, Lars Allolio-Näcke, and Carl Ratner, 169-85. London and New York: Routledge.

Lothane, Zvi. 2001. “The Deal with the Devil to 'Save' Psychoanalysis in Nazi Germany." Psychoanalytic Review 88, no. 2: 195-224.

Loughran, Tracey. 2012. "Shell Shock, Trauma, and the First World War: The Making of a Diagnosis and Its Histories." Journal of the History of Medicine and Allied Sciences 67, no. 1: 94-119.

Murphy, Gardner. 1960. Historical Introduction to Modern Psychology. London: Kegan Paul.

Pickren, Wade, and Alexandra Rutherford. 2010. A History of Modern Psychology in Context. Hoboken: John Wiley \& Sons.

Risen, James. 2015. "Pentagon Curbs Use of Psychologists with Guantánamo Detainees." The New York Times, December 31. www.nytimes.com/2016/01/01/us/ pentagon-curbs-use-of-psychologists-with-guantanamo-detainees.html.

Roazen, Paul. 1976. Freud and His Followers. New York: Meridian Books.

Rose, Nicolas. 1985. The Psychological Complex: Psychology, Politics, and Society in England, 1869-1939. London: Routledge and Kegan Paul.

- 1998. Inventing Ourselves: Psychology, Power, and Personhood. Cambridge: Cambridge University Press.

Sampson, Edward. 1981. "Cognitive Psychology as Ideology." American Psychologist 36, no. 7: 730-43.

Searle, John. 1995. The Construction of Social Reality. London: Penguin Books.

Shweder, Richard. 1991. Thinking through Cultures: Expeditions in Cultural Psychology. Cambridge, MA: Harvard University Press.

Taylor, Charles. 1995. "Overcoming Epistemology." In Philosophical Arguments, 1-19. Cambridge, MA: Harvard University Press. 
Toulmin, Stephen. 1992. Cosmopolis: The Hidden Agenda of Modernity. Chicago: The University of Chicago Press.

Woodworth, Robert S., and Mary R. Sheehan. (1931) 1975. Contemporary Schools of Psychology. London: Methuen.

Wundt, Wilhelm. (1900-1920). Völkerpsychologie. Eine Untersuchung der Entwicklungsgesetze von Sprache, Mythus und Sitte. 10 vols. Leipzig: Engelmann. 



\title{
The Social Roles and Positions of the Hungarian Psychologist-Intelligentsia between 1945 and the 1970s: A Case Study of Hungarian Child- Psychology
}

\author{
Melinda Kovai
}

Each society and each historical period have produced their respective ideologies and technologies of regulating people's relationships with their own selves. These provide the principles for good and righteous conduct that connects individuals to the order of production (that is to actual economic and power relations) in a satisfactory way. Among others, psychology fulfilled this function since the end of the nineteenth century, when Western capitalism expanded and modernized. More specifically, the role of psychology was to embed or frame the imperatives of good and righteous living in a medical discourse of truth and to reinterpret it through dimensions of normalcy and pathology (see Foucault 2002, 2006; Miller and Rose 2008; Rose 1990, 1996a, and 1996b; Cushman 1995).

Thus the inner world of the individual and human relationships had been presented as subjects of a universalistic scientific expertise, which was by its nature "international." Additionally and nonetheless, the content, aims, and moral stakes of psychology have taken different forms in mutually dependent and unequal states across the world. Several studies discussed how psychology became one of the most important techniques for forming the subjects of twentieth-century Western capitalism. Less attention was paid, however, to Eastern European state socialisms, where psychology operated in the context of a catching-up modernization project.

In this case study, I will show how the geopolitical situation of a country, namely Hungary, influenced the content of psychological knowledge, and how 
the professional identity of a psychologist changed in the context of specific policy priorities.

The post-war history of Hungarian psy-sciences is inseparable from the Cold War and the international political-economic integration of the country. After World War II, during the so-called coalition era, the psy-sciences had equally close ties to their own domestic tradition and to the Western, AngloAmerican psychotherapeutic discourse that had greatly strengthened and became increasingly integrated during the war. Moreover, the psy-sciences were deeply nested in the vast policy interventions of the Hungarian state, and had also gained prominence through the Communist Party's conceptions of policy. This constellation proved fortunate for a short period in the sense that it led to the unprecedented expansion and institutionalization of the psy-sciences in Hungary. Even though the psy-sciences had already developed strong ties with the international (Western) scientific discourse, this short expansive period was in many aspects particular and divergent from both Western and Soviet developments. ${ }^{1}$ If we examine the policy practices oriented to the formation of

1 The rapid and innovative expansion of Soviet psychology after the 1917 revolution was both triggered by strong state intervention and grassroots activism. Soviet psychology explicitly aimed to assist economic-technological modernization, the catching up of the new Soviet state, as well as-because of the promise of socialism - the elimination of extreme social inequality. Following the Stalinist turn, alongside the development of bureaucratic state socialism and its legitimizing ideology, the function of psy-sciences had transformed as well. In the modernization paradigm initiated after the NEP, the main tools of the re-stratificatory class policy (the elimination of the civilizational backwardness of the worker and peasant masses and the provision of access to the bureaucracy for working class cadres) were administrative interventions and applied psychology, which examined the relations between the development of personality and its class position, both of which were eliminated from the policy repertoire. Creating "the new man," that is the Soviet subject, was no longer a task for psychology, but rather that of the cult of personality, propaganda, and the ritual practices of state bureaucracy. Psychology of the NEP era had become ideologically and technically unnecessary in the context of catching-up industrialization, which relied on the inner resources of the country and the intensified exploitation of the population. The showdown between the "old" intellectuals and Stalin's other political opponents; the transformation of education policy; the logic of the all-encompassing party bureaucracy; the cult of personality; and the new system-ideology, as well as the demand to fuel the concept of the Western enemy altogether led to the elimination of the huge post-revolutionary institutional network of psychology operating in the areas of pedagogy, child care, the military, and the world of labor. 
subjectivity, we will see that their stakes were linked to the coalition era's reform visions and power struggles, and the role of psychology was embedded in this particular context. After the country's subordination to the Soviet sphere of influence, the Stalinist bureaucratic and political structure was adopted by Hungary too, which entailed the liquidation of those fields of psy-sciences that had long been eliminated in the Soviet Union as well as the implementation of the "Pavlovian" neurological discourse. The process of Stalinization created a symbolically divided scientific field: the international scientific discourses operated along a "Western capitalist" and "Soviet socialist" division in the Soviet Union. Hence Hungarian psy-sciences had also been pushed out from the domain of policy-making and became a persecuted Western technique. After the Twentieth Congress of the Soviet Communist Party, the rehabilitation and re-initiation of Hungarian psychology also followed the Soviet model. In the new political discourse, the status of sciences and that of psychology had changed. After a decade of prohibition, the rehabilitation and reinstitutionalization of Hungarian psychology was an attempt to catch up to the Western discourse, which was perceived as international and universal. From the early sixties onwards, the fate of Hungarian psychology ceased to be directly linked to the Soviet Union. However, an indirect link remained intact by the characteristic policy-making mechanisms of the Kádár era.

Due to limitations of space, this chapter aims to present the characteristics of Hungarian psychology through the lens of child psychology in these three decades.

\section{Antecedents: The Psychologization of Childhood}

Child-focused psychological expertise began to institutionalize in the early twentieth century in close relation with a newly-established child protection service, philanthropic initiatives that provided aid for poor mothers and their children, and also with the pedology movement, ${ }^{2}$ which advocated for public

2 The pedology movement examined the anatomic, physiological, psychological, and sociological characteristics of the child in a complex way. In the 1890s, these fields of knowledge were interlinked by the assumption that childhood is essentially a different state than adulthood. The methods of pedology such as empirical observations, questionnaires, and the use of various instruments of measurement like ability and achievement tests, were borrowed from empirical psychology and psychotechnique. 
educational and pedagogical reforms. The institutionalization of psychology and pedology began before World War I, was suspended after the fall of the Hungarian Republic of Councils (the 1919 Hungarian Soviet Republic), and continued again from the mid-1920s onwards. Neo-nationalist cultural policy and state social policies aimed at mitigating the effects of the recent politicalsocial shocks perceived psychology as an efficient tool of professional intervention. Therefore, greater state resources were allocated to the development of psychological vocational guidance, special and remedial schools, and other institutions for psychological expertise focusing on child behavior (child guidance clinics, psychotherapy, and psychological research).

Between the two world wars, childhood was a central domain of public health and security discourse, which addressed the possible ways to improve the quality of the population. In this period, several state-run research institutions as well as child counseling and vocational guidance centers were established. ${ }^{3}$ Yet these institutions employed few psychologists, and they only reached a limited segment of the population. Child psychology primarily operated under umbrella institutions subsidized by civic philanthropy: orphan care, mother and infant protection, and educational consultancy. The professional community at that time was small and its members were enthusiastic young doctors, teachers, and a few psychologists who had graduated from Western universities and were, without exception, deeply committed to scientific theories and social reforms. In these circles, Jews who had been forced out of higher education and public services as well as bourgeois women aspiring to intellectual professions were characteristically overrepresented.

Psychological expertise on childhood was a consistent and central element of reform plans aimed at the exposure and resolution of social problems across the intellectual streams of the interwar period (from the völkisch movements to public health care and mental hygiene movements). However,

3 Two institutions played pivotal roles after 1945. The Hungarian Royal Laboratory of Psychology and Special Education established and directed by Pál Ranschburg was divided into two institutes in 1927. One department continued to work as the Research Institute of Child Psychology and was directed by János Schnell; the other, the Hungarian Royal National Laboratory of Pathology and Special Education, was directed by Lipót Szondi. Their institutional profiles were different. Besides research activities (the development of ability and achievement tests), Schnell's institute mostly focused on child-psychotherapy and child guidance, whereas Szondi's laboratory primarily functioned as a research institute focusing on the area of the pathology of achievements and abilities of mentally disabled children and orphans. 
it would be an exaggeration to state that psychology was a dominant discourse within public institutions or in the self-definition of individuals between the two world wars. Nevertheless, psychologists had high ambitions with regard to their discipline. The common denominator or shared argument between psychology and the eugenics, mental hygiene, and reform pedagogy movements was that social problems are psychological problems and vice versa. Therefore, they argued, in ideal conditions (e.g., with appropriate state subsidies and intervention) psychological expertise would be capable of improving the "quality" of the population, and, by extension, resolving social problems such as poverty, crime, alcoholism, prostitution, and political "deviances" (see, e.g., Lechner 1919; Nyírö 1939; Oláh 1923; Szondi 1939).

\section{5-1948: The "Psycho-Boom" in Public Education}

After World War II, the institutionalization of scientific knowledge about childhood significantly expanded all over the Western world. By this time, psychology had developed into an integrated and formally institutionalized scientific domain. The centers of this expansion were the most powerful states politically and economically: Great Britain and the United States. During the war, both in the army and in the hinterland, psychology had become an expertise and technology deployed to influence and manage interpersonal relations. Later on, these technologies quickly diffused across the public spheres of the emerging Western welfare democracies from the public service sector to business corporations. The parent-child relationship became one of the most important fields of scientifically analyzed interpersonal relations, a key terrain for fashioning successful individuals capable of managing themselves and their social productivity in both the workplace and the family.

Child psychology underwent a great expansion in postwar Hungary too. Yet here, the expertise of developmental psychology was oriented to a leftist class policy. After 1945, the earlier established small therapeutic institutes grew into huge state-operated institutions, and the enthusiastic volunteers of prewar philanthropic associations became public servants. The widespread institutionalization of the discipline was interlinked with the communist party's educational reform plans, most importantly the introduction of eight-grade compulsory public education. Political power strove for the mass mobility of workers' and peasants' children by leveraging the public educational system. 
The radical postwar transformation of public education equally served to mitigate the extreme labor shortage that resulted from industrialization, modernization, the reorganization of the state bureaucracy, and the socialist society's egalitarian project. These factors were mutually reinforcing. New industrial jobs required higher general rates of education and professional qualification. The labor shortage was further aggravated by the fact that after the years of transition, the new Soviet model of a bureaucratic single-party system was in dire need of educated working class and peasant cadres loyal to the socialist political system. In the language of ideology, this claim was phrased as the creation of the "new elite" and "new intellectuals." The school became one of the most important fields of class struggle (Kovai and Neumann 2015).

In the discourse of psychology, the same political force prompted an interest towards the psychological links between ability and class position. The main task of child psychology was to develop an educational system and curriculum actually capable of reducing social difference. The communist party still considered psychology to be the most important expert knowledge for the formulation of public education policy in the year of the turn (to Stalinism) in 1948. The National Pedagogical Institute, which, under direct party control, provided expertise for educational reform, was established that same year. Its director, Ferenc Mérei, ${ }^{4}$ was called "the communist pope of psychology." This refers to his professional and political powers, as well as to the contemporary prestige of psychology and the prophetic role of the intelligentsia in party bureaucracy. Citing him here:

4 Ferenc Mérei (1909-1986) was born in Budapest to a Jewish petit bourgeois family. His parents were photographers. At the end of the 1920s, he joined the literary circle of the avant-garde worker poet, Lajos Kassák. Because of the numerus clausus, he graduated from the Sorbonne. Initially he studied political economy, literature, philosophy, and sociology, later he became the disciple of the Marxist psychologist Henri Wallon and developed an interest in child-psychology. He obtained a degree in psychology, sociology, pedagogy, and vocational guidance. In 1930, he joined the French Communist Party and carried out illegal activities under the pseudonym "Poppy." His circle of friends (the "Tribe") were dissident artists and intellectuals. In 1934, he worked for János Schnell's institute as a volunteer, and later he also volunteered in Lipót Szondi's research about "fate analysis." After the anti-Jewish laws were issued, he worked in the psychotherapeutic ambulance of the Jewish Patronage Association directed by Júlia György. In 1942, he was ordered to forced labor and sent to the Soviet front. In 1944, he escaped and joined the Red Army where he served as a captain. Having returned home in 1945 as a committed and by then "legal" communist, he became one of the main organizers of scientific research. 
I felt that I was one of the few with a revolutionary soul who were oriented to the pedagogy of childhood. I seriously prepared myself for this. I knew that a moment would come when the school system could be changed. I had not known yet what a school system was like. I had never been involved in public activities before. I only had experience from the illegal movement where I'd seen five people, ten people, twenty people. I read. But I had no idea that a Ministry was a big apparatus, actually, that deals with the affairs of the whole mankind or at least a country. (Szilágyi 1972, 285)

Apart from this, grassroots psychological laboratories, psychological parent counseling courses, and vocational guidance centers were established across the country, and the staff consisted of enthusiastic educators who volunteered their spare time. These initiatives were soon organized into a national network under the coordination of the National Institute of Child-Psychology, ${ }^{5}$ which by then gained status in an academic research institute. Besides its guidance and therapeutic activity, through its regional networks, the Institute carried out research commissioned by the Ministry of Education in order to pre-assess reform plans. This research, just as the other services provided by the centers in the networks (ability tests, day care centers, training for parents and teachers), was aligned to the principles of the educational reforms, the chief aim of which was the enhancement of overarching social mobility (Barra 1947; Baranyai et al. 1947; Schnell 1968; Neményi 1979).

The great boom of Hungarian psychology was interrupted by the Soviet radicalization of education reform. ${ }^{6}$ In 1948, a class-based quota system was introduced in secondary and tertiary education. In 1950, again following the Soviet model, the institutions of psychology were almost liquidated without exception. The National Pedagogical Institute was the last one to be closed down. Since Stalinist ideology proclaimed that the bureaucratic single-party

5 The predecessor of the National Institute of Child-Psycholgy was the Research Institute of Child-Psychology. The latter was established in 1927 as one of the successors of Pál Ranschburg's institute. Before the war, this institute was one of the most important centers of Hungarian psychology, but it had only a few permanent job posts, and most of the work was carried out by young volunteers. After 1945, the institute received official academic status, which greatly increased its prestige. The former volunteers became public servants.

6 On Soviet child-psychology, see Fitzpatrick 1979; see also Joravsky 1989; and Etkind 1997. 
system is the realized form of socialism, scientific inquiry about the relationship between class position and skills was regarded as ungrounded or possibly relevant only in capitalist societies. In these ideological attacks, psychology was argued to be a "bourgeois doctrine" for psychologizing social inequalities as "abilities" or "talents," and thus legitimizing them. Echoing the same accusations, the former leaders and fellows of the liquidated research institutes were expelled both from the party and from the scientific public. The previously approved universalistic scientific discourse was debunked as the ideology and technology of Western capitalism, and it was relocated to the other side of the Iron Curtain and thus lost its scientific status.

\section{6: The Failed Program of "Socialist Enlightenment" and the Beginning of Re-Institutionalization}

After the Twentieth Congress of the Soviet Union's Communist Party, a new chapter began in the Cold War. Scientific technology became the cornerstone of the military-economic competition aimed at catching up with the West on the Soviet side of the Iron Curtain too. Hence, following the Soviet model, psychology was rehabilitated in Hungary after 1956 as well.

In the period right before the revolution, the rehabilitation of psychology was framed as a public issue on the reformers' agenda. The freshly rehabilitated, leftist, reform-communist experts (first of all Ferenc Mérei and his colleagues in the former National Pedagogical Institute) conceptualized the mission of psychology as they did before Stalinist extremism: as a discipline that served the genuine values of socialism as well as the public good.

The participants of the heated intellectual debates ${ }^{7}$ criticized the uncritical imitation of the Soviet model as well as ungrounded political decisions (see the debates of the Petöfi Circle VI. 1989; Szabolcs 2006; Zibolen 1989).

\footnotetext{
${ }^{7}$ From the point of view of child psychology, two significant events took place in 1956: the Petöfi Circle's pedagogy discussion forum held in September and October, and the conference of the teachers' union held in Balatonfüred in October. Following the direction of the Twentieth Congress of the Soviet Communist Party, the aim of the Balatonfüred conference was to draft the five-year plan for educational research commissioned by the party and to commit the legitimate leaders of the profession to drafting an educational policy proposal (Zibolen 1989; Szabolcs 2006).
} 
The prime focal point of the criticism was that psychologists and psychological expertise ("pedology") had been completely ignored. The program of "socialist enlightenment" announced in the field of pedagogy and public education explicitly defined itself as a rational, scientific, but morally committed, leftist project.

The collaboration of state bureaucracy and science will not be productive unless we create vivid, hot-blooded scientific policy, which is equally Hungarian and modern. Its broad perspective points toward modern, automatized industrial production, yet does not lose sight of the humanity and democratic values of the socialist idea even for a brief moment. (Ferenc Mérei's speech in Balatonfüred quoted in Zibolen 1989, 87; cf. Szabolcs 2006)

The future of the proposals intermingled with those who proposed them: the fate of reform-communist intellectuals. The protagonist-at least from the point of view of political power-was again Ferenc Mérei. After the 1956 revolution, the assessment of the reform plans was determined by the political assessment of Mérei. During the revolution Mérei neither took leadership positions, nor did he directly participate in armed resistance. Invited by the students of the faculty of humanities, he was elected the professor-president of the University's Revolutionary Committee and was one of the leaders of the teachers' subcommittee of the Revolutionary Committee of Hungarian Intellectuals. As the process of retaliation unfolded, Mérei was determined to be among the punishable "counter-revolutionary" communist intellectuals. The members of the "Mérei-Fekete Group" were arrested and charged with conspiracy against the state in October 1958. Later they were sentenced to ten years in prison; but he was released by the general amnesty of 1963 .

With the repression of the revolution, the program of "socialist enlightenment" was doomed to fail as well. The psychologists did not become policymaking intellectuals, and psychology lost its political significance as well. In comparison to the Stalinist power relations of the Rákosi era, one of the most important characteristics of the Kádár era was political compromise. Centralized state power gradually amalgamated into the fertile soil of informality (detailed in Böröcz 1990). The system of personal relationships and mutual favors become just as central to the field of psychology, as it was in many other spheres of Hungarian society. 


\section{From Class Policy to Informality: The Network of Child Guidance Clinics}

In the ten years that had passed between the liquidation and the re-launching of Hungarian psychology, the world as well as Hungarian state socialism had fundamentally transformed. The uni-directional colonial-style dependence on the Soviet Union was replaced by a dual dependence: although political dependency on the Soviet Union prevailed, it was complemented by the country's economic dependence on Western states. In this context, the Hungarian communist party practically gave up its previous modernization project, which was originally framed as an alternative to Western capitalism. In a pacifying compromise, in exchange for people's political passivity, the party gave up its mobilizing ambitions and guaranteed the freedom of the private sphere and a relatively high standard of living. The regime did not need "engineers of the soul" any more, and the program to create the "new man" and a "new society" became an empty political slogan. Hence psychology lost its former political relevance too. Apart from a few exceptions, psychologists abandoned the idea of creating a socialist discipline that is an alternative to Western psychology.

From the early seventies on, the most important dimension of the Hungarian psycho-boom was the intensive expansion of psychological expertise on childhood. In this, the development of child guidance played a crucial role. It was the psychologists' deliberate strategy to institutionalize child psychology as distant and distinct from the school system as possible. In the light of history, this desire is understandable. However, it is much less clear how social inequalities or society as such faded away from the discourse of Hungarian (child)-psychology. It is especially surprising in light of the fact that the same psychologists who played a pivotal role in the reestablishment of child guidance in the early sixties had been employed in the National Pedagogical Institute (or in other, similar institutes) during the coalition era and had been enthusiastically involved in the development of psychological research committed to a more egalitarian school system.

To interpret this phenomenon, we need to consider four questions. Why was the problem of educational inequality addressed as a sociological and not as a psychological issue in the 1960s? What kind of interests and opportunities guided psychologists in the re-institutionalization of the field? What was the international scientific context of child psychology at the time and how 
did it relate to the views, practices, and institutions of contemporary Hungarian psychology?

The postwar initiatives that attempted to create the "new elite" were recontextualized by the end of the fifties. On the one hand, as a final gesture of retaliation for the 1956 Revolution, the party proclaimed a new cultural policy. In order to reconcile with the middle class, the decision of the Eighth Party Congress abolished the registration of students' class origin. On the other hand, to prepare for marketization reforms (the so-called New Economical Mechanism), the quality and productivity of education as well as its links to the labor market were reframed as a dimension of economic policy (Kovai and Neumann 2015).

Because of the abolition of the educational quota system and the "economic turn," the problem of educational inequalities had become one of the most important issues on the education policy agenda. Yet the new educational policy had taken shape in a completely new force field, inhabited by new, previously non-existent positions, actors, and dynamics. Most notably, the relationship between politics and sciences had been transformed. From the beginning of the early sixties, it was not just psychology that started to reinstitutionalize, but also empirical social sciences, which had been similarly marginalized during the Stalinist years. In this era, sociological research was typically expected to provide evidence for political and economic reforms.

The sociological stratification surveys carried out in the framework of preparations for economic reforms rendered educational inequalities empirically measurable. As part of the same process, sociologists entered the field of education policy and established a new professional legitimacy and intellectual identity precisely by "revealing" the interrelation between the education system and social inequalities. In the field of education policy, the preparations for market reforms created demand for such policy-oriented research, which was capable of approaching macro-level systemic problems. Hence, the social justice aspect of the school featured as an ideological, pedagogical, economical, and sociological problem simultaneously.

Skill-based selection and the equalizing function of education appeared as conflicting expectations in light of the results of sociological research. Meritocratic selection must be ensured, yet all research proved that the school favored middle-class children, and the achievements of working-class children significantly lagged behind. In terms of concrete political proposals, the question remained: how can we raise the level of working-class children's achievement to that of middl-class children? 
The education policy decisions of the era aimed to find a compromise between the contradictory political expectations of egalitarianism and economic efficiency and to reconcile the diverse interests of particular professional groups (pedagogues/educators, sociologists, economists, vocational training experts, etc.) (for details, see Halász 1984, 1988, 1988-89). Hence educational reforms in 1961, 1965, and then in 1972 did not radically change the system but only attempted to mitigate its dysfunctions, and the problems identified in the sixties-from the quality of education to counter-selection-also prevailed in the seventies despite the reforms.

Returning to child-psychology, it becomes clear that the field was absolutely neglected by public education policy in the sixties. There may be several possible reasons for this. On the one hand, the re-emergence of the problem of educational inequalities on the education policy agenda was due to the economic reforms, and, as we have seen, policy-makers expected a reform knowledge base from the discipline of sociology, which was in the midst of reinstitutionalization. The conceptualization of sociological problems and reform solutions at the time (Ferge 1972, 1976; Havas 1972; Gazsó and Várhegyi 1975; Gazsó 1971, 1979; Pataki 1968) resembled the way Ferenc Mérei and his colleagues approached the same issues in the former National Pedagogical Institute. Yet the pedagogy of the time "forgot" about the aspect of social inequality throughout the rigorous elaboration process of curricular reforms. At the time, psychologists were preoccupied with the celebration of their recently regained independence and, bearing in mind their previous experiences, they were working hard to separate themselves from educational experts both institutionally and disciplinary.

In short, during the sixties, everybody seemed to have "forgotten" about the vast expertise on pedagogical methods that ameliorated educational inequalities accumulated by psychologists before the introduction of the educational quota system. In addition to the processes described above, Ferenc Mérei himself may have played a pivotal role in this. In the period between 1945 and 1949, he oversaw or directed the research on the psychological factors of educational inequality conducted by the National Pedagogical Institute. After Mérei's imprisonment, he was persona non grata both as a person and as a scholar, and references to his name were banned from psychological journals. Mérei, like most of the other communist intellectual prisoners, was released in the general amnesty of 1963. Due to his criminal record he was banned from university posts and research institutes. He became the director of the psychological lab of the National Institute of Psychiatry and Neurology. His name slowly reemerged 
in scientific publications, but he was banned from the domains of child psychology and educational research. He primary concentrated on the reinstitutionalization of clinical psychology and published widely in this area.

Thus education policy did not need psychologists any more, but neither did psychologists need education policy. Contemporary psychologists intentionally sought to re-institutionalize child psychology as psychotherapy and not as pedagogy, and thus to separate it from the educational system.

Similar to clinical psychology and psychotherapy, the institutionalization of child guidance clinics and child psychotherapy was characteristic of this epoch. The recipe for whitewashing was as follows: an expert who was committed to psychology and was also politically well situated arranged the establishment of a professional group in a second-tier public institution such as a hospital ward or a social service office. The small information groups continued to lobby informally through their respective patrons and developed a formal institutional system from the ground up.

These professional communities were organized informally, typically around a charismatic authority. They gathered in private meetings, where one could only gain entrance on the basis of personal recommendations. For a few, these groups offered access to knowledge and skills (such as current Western literature, diagnostic and therapeutic methods, and supervision) that was only partly offered by a formal university education. These workshops were not illegal, but the fact that they were organized informally and that psychology had been considered a "reactionary," "anti-systemic" doctrine just a few years earlier, gave them a status similar to the political opposition.

In the case of child psychology, the patron was the powerful cultural policy-maker of the era, György Aczél. In the 1930s as a teenager, he was aided by the psychotherapeutic clinic of the Jewish Patronage Association's orphanage. By 1968, he held sufficient power to express his gratitude to his psychologist, Júlia György. His "gift" was the Capital's Child Psychology Institute, established by the City Council for Júlia György personally. She could choose her colleagues and received a wide berth to create the professional profile of the Institute. Hence the Institute, known as "Faludi Street," explicitly grounded itself in older psychoanalytical traditions. The staff came from the generation who had been marginalized for taking part in generating the psychological basis of the postwar equalizing educational reforms. Citing one of them:

Gyurka Vikár told me ten years later that back in the times when I had only started to work in the Faludi for a year and organized a sort of 
"secret" psychoanalytical seminar-not the curriculum was secret but we concealed that is had a psychoanalytic character-so Júlia György asked Vikár “tell me, Gyuri, won't we get into trouble for this?” But Vikár reassured her and indeed we did not get into trouble. (Lévai 2003, 70)

A few psychologists from this generation with good political connections to the Budapest City Council managed to negotiate the local government's control over the maintenance of the newly established network of child guidance clinics instead of the oversight of the Ministry of Education. They also succeeded in making Faludi Street the professional training center for psychologist counselors employed at the child guidance clinics. Annabella Horányi recalled:

It had to be decided in which direction the child counselling network would be developed. Either it could have shifted towards pedagogy to become a diagnostic station with the task of guiding children to the proper institution and therefore complying with the pressure coming from the schools to free them from problem children; or in the unreasonable battles with the educational government, to improve professional conditions. Or we could master the knowledge and approach, which commits itself to the children who present symptoms of mental illnesses, and undertake psychotherapeutic work. It was at this time when Júlia György offered her help to train the psychologists of the child guidance clinics and the orphanages at the City Council. Once the head of an important institution accused me of selling the capital's child guidance network to the Faludi. I do not deny it, and I am still proud of it. (Horányi 1997, 95-96)

The training, for which there was a fee, was held on so-called "Faludi Saturdays," and participants attended the events in their free time. The course did not offer any official qualification, yet it had high informal prestige within the professional community. Faludi Saturdays were the sole opportunities to take part in supervision, clinical case study groups, and to become familiar with current Western literature.

Therefore the revival of Hungarian psychotherapy was more strongly connected to contemporary Western discourse than to its own disrupted past. This is mainly due to the fact that during this "lost" decade, on the other side of the Iron Curtain, the psy-sciences went through an unprecedented expan- 
sion. By the second half of the sixties, this process produced a huge boom of scholarship, which reached Hungary with a ten-year delay. In the sixties, Hungarian experts aimed to catch up to the "international results" presented by the comprehensive and complex expertise, institutions, and practices that were the genuine products of Western welfare democracies.

The 1960s was the time of the psycho-boom, and psychology became the most important expertise and narrative that shaped personal and group identities in the West. In this discourse, the behavior and well-being of "psychologized" individuals was not influenced by his or her class position or public competencies, but by his or her private emotional relations, choices, and groups. Hungarian psychologists fully adopted this view. After 1956, psychology was no longer accused of individualizing social problems or serving the interests of the ruling classes. For psychologists, the cost of political opposition was the maintenance of a "second public sphere" and securing professionalism. From the perspective of psychology, the state was unable to see "real" individual and social situations, and consequently the public conversations around the public competence of individuals were regarded as empty political-ideological slogans. In the moral universe of psychologists, psychology was the alternative to politics: it focused on the "real problem" of "real people," and not on empty public life.

This status was strengthened by the fact that contemporary Hungarian psychotherapy exclusively referenced Western expertise, and, through this, it proclaimed representation based on the binary opposition of the imaginary West and East (the countries of Soviet Bloc) such as: center-periphery, expertise-dilettantism, freedom-slavery, civilized-barbarian, illegal-legal, etc. Thus, the prestige of such expertise was associated with illegality, informality, "Westernism," and made the workshops especially popular for a generation of young professionals.

On the other hand, child psychology became a morally exalted profession in the view of psychologists. Moving beyond the traditional values of the mental hygiene movement such as a sensitivity to social issues and the belief that treating children's mental problems makes future adults happier, more useful, and fully-fledged and less dangerous members of the society, this conceptualized psychoanalysis as a moral movement. The studious, half autodidact groups had close ties to the renaissance of the "Budapest School" of psychoanalysis, perceived as unjustly condemned. From this perspective, the worlds beyond and preceding the Iron Curtain coalesced. As György Vikár recalled in his memoir: 
It was an honorable task for all of us who gathered on the ground floor of that house on Faludi Street 5 at the end of 1968 and at the beginning of 1969. Our undertaking was the resuscitation of a therapeutic stream within an institutional framework; we were convinced that it was necessary, not only for the sake of the children, but for the sake of Hungarian health care culture as such. This was a novel task for all of us, so much so that-although we followed our great ancestors' tracks and we were already experienced-we needed to teach and learn from each other, and most of all, the only way to succeed was through learning collaboratively. (Vikár 1997, 20)

\section{Conclusion}

Importantly, the psychotherapeutic field in the sixties regarded informal organization as a temporary necessity and ultimately strove for formal institutionalization. Also during the sixties, the international scientific discourse, which had been divided by the Iron Curtain, reintegrated. The expertise applied in the mental health system of Western welfare states became the standard for Hungarian professionals. By means of political lobbying, the "second public sphere" of the health care system gradually infiltrated the psychological profile of public institutions, and the expansion of the scientific field also became possible. Since all the conditions necessary to develop professional careers were present, the psychologists of the time were not interested in changing society. Although at the time, these possibilities were perceived as the consequences of a compelled bargain with retrograde, dilettante politicians, retrospectively, this narrative rather appears as a moral argument for the practice of psychology and the organization of the scientific field.

The Hungarian psychotherapeutic discourse of the seventies no longer made a link between individual and social problems. Of course, this does not mean that psychologists did not recognize the social background of psychopathologies. In the seventies and eighties, the high frequency of neurosis, alcoholism, suicide, and juvenile delinquency (in contemporary terms, the "disorders of social integration") was highly publicized and these problems were interpreted as symptoms of the crisis of society and the consequences of abortive welfare policies. But psychology, because of its historical antecedents, inevitably perceived and treated these symptoms as individual pathologies. 
This story is precisely about how expertise centering on the inner world of the individual is determined by such antecedents. Psychology can be an innovative and sensitive technology used to eliminate social inequalities; but equally, it can be a daily spiritual practice for the individual assimilated into post-Fordist rules of production who is working perpetually on his or her identity. It can be a pseudoscience serving Western bourgeois interests; or a secret network of informal communities - and perhaps many other things as well. This all depends on the constraints and opportunities we have to remedy ourselves in particular times and places.

\section{REFERENCES}

Barra, György. 1947. “Nagy László és Ranschburg Pál nyomában. A gyermeklélektan vidéki úttörői” [In the footsteps of László Nagy and Pál Ranschburg: The provincial pioneers of child psychology]. In Tanitás és értelmi fejlödés [Teaching and cognitive development], edited by Erzsébet Baranyai et al., 158-70. Budapest: VKM.

Borgos, Anna, Ferenc Erős, and György Litván, eds. 2006. Mérei élet-mü [The Mérei oeuvre]. Budapest: Új Mandátum.

Böröcz, József. 1990. "A kádárizmustól a parlagi kapitalizmusig. A fejlett informalizmus építésének időszerü kérdései" [From "Kádárism" to provincial capitalism: Current questions of the construction of advanced informalism]. Mozgó Világ 16, no. 8: 61-66.

Cushman, Philip. 1995. Constructing the Self, Constructing America: A Cultural History of Psychotherapy. Cambridge, MA: Da Capo Press.

Etkind, Alexander. 1997. Eros of the Impossible: The History of Psychoanalysis in Russia. Boulder, CO: Westview Press.

Ferge, Zsuzsa. 1972. "A társadalmi struktúra és az iskola közötti néhány összefüggés" [Some connections between social structure and school]. Szociológia 1: 10-36.

— 1976. Az iskolarendszer és az iskolai tudás társadalmi meghatározottsága [The social determination of the school system and school knowledge]. Budapest: Akadémiai Kiadó.

Fitzpatrick, Sheila. 1979. Education and Social Mobility in the Soviet Union, 19211934. Cambridge: Cambridge University Press.

Foucault, Michel. 2003. Abnormal: Lectures at the College de France, 1974-75. Translated by Graham Burchell. London: Verso.

- 2006. Psychiatric Power: Lectures at the College de France, 1973-74. Translated by Graham Burchell. London: Palgrave Macmillan.

Gazsó, Ferenc. 1971. "Társadalmi mobilitás és az iskola” [Social mobility and education]. Társadalmi Szemle 5: 67-78.

_ 1979. "Egyenlőtlen esélyek és az iskola" [Unequal chances and the school]. Valóság 9: 1-11.

Gazsó, Ferenc, and György Várhegyi. 1965. “A müvelődési egyenlőtlenségek és az iskolarendszer" [Educational inequalities and the school system]. Valóság 12: 54-61. 
Halász, Gábor. 1984. “Az oktatáspolitika szerkezete a hatvanas-hetvenes években” [The structure of education policy in the 1960s and 1970s]. Medvetánc 2-3: 73-96. Availabel online at: http://halaszg.ofi.hu/download/Medvetanc.pdf.

— 1988. "Oktatáspolitika és neveléstudomány a hetvenes években: a hatos föirány története" [Education policy and pedagogy in the 1970s: The history of the sixth direction]. Tájékoztató a közoktatási kutatásokról 9: 5-49. Available at: http://halaszg. ofi.hu/download/Hatos_foirany.pdf.

_ 1988-89. "Radikális ideológia és kompromisszumos gyakorlat: oktatáspolitika Magyarországon a hatvanas évek elején” [Radical ideology and compromised practice: Education policy in Hungary in the early 1960s]. Medvetánc (1988/4, 1989/1): 243-52.

Havas, Gábor. 1973. “A munkásgyerek, munkásszülő és az iskola” [The working-class child, the working-class parent, and the school]. Szociológia 4: 519-40.

Horányi, Györgyné. 1997. "György Júlia és a Faludi, az alakuló nevelési tanácsadó hálózat szakmai bázisa" [Júlia György and "the Faludi," the professional base of the forming network of child guidance clinics]. In György Júlia emlékkönyv [Festschrift for Júlia György], edited by Györgyné Horányi, 15-16. Budapest: Fővárosi Pedagógiai Intézet és Nemzeti Egészségvédelmi Intézet.

Joravsky, David. 1989. Russian Psychology: A Critical History. Oxford: Blackwell.

Kovai, Melinda, and Eszter Neumann. 2015. "Hová lett az egyenlősítő közoktatás? A komprehenzív iskolareform sorsa Angliában és Magyarországon” [Where had equalizing education policy gone? The fate of compehensive education reform in England and Hungary from 1945 to the 1980s]. Educatio 4: 65-78.

Lechner, Károly. 1919. "Az elmefogyatékosságok szerepe a társadalomban" [The role of mental retardations in society]. Természettudományi Közlöny 51: 725-30; 773-86.

Lévai, Júlia. 2003. Interview with Lívia Nemes. Budapest: 1956 Institute, OHA, 768.

Miller, Peter, and Nikolas Rose. 2008. "On Therapeutic Authority: Psychoanalytical Expertise under Advanced Liberalism." In Governing the Present, edited by Peter Miller and Nikolas Rose, 142-73. Cambridge: Polity Press.

Neményi, Mária. 1979. “Beszélgetés Molnár Imrével” [Discussion with Imre Molnár]. Magyar Pszichológiai Szemle 19, no. 1: 83-92.

Nemes, Lívia. 1997. "Visszaemlékezés a 'Faludi'-ra” [Remembering “the Faludi”]. In György Júlia emlékkönyv [In meomoriam Júlia György], edited by Györgyné Horányi, 21-22. Budapest: Fővárosi Pedagógiai Intézet és Nemzeti Egészségvédelmi.

Nyírő, Gyula. 1939. “Szociális elmehygiene” [Social mental hygiene]. Népegészségügy 20, no. 3: 163-79.

Oláh, Gusztáv. 1922. "Védekezés az elmebetegség ellen” [Preventing mental illness]. Népegészségügy, 11.

Pataki, Ferenc. 1968. "Nevelésügyünk és a szociológia" [Our education policy and sociology]. Társadalmi Szemle 11: 72-82.

Rose, Nikolas. 1990. Governing the Soul: The Shaping of the Private Self. London, New York: Routledge.

Schnell, János. 1968. A Fővárosi Gyermekideggondozó Hálózat kialakulása, tudományos és történeti elözménye [The development and scientific and historical antecendents of the Metropolitan Institute of Child Psychiatry]. Budapest: Központi Gyermekideggondozó Intézet. 
1996a. "Psychiatry as a Political Science: Advanced Liberalism and the Administration of Risk." History of Human Sciences 9, no. 1: 1-23.

- 1996b. Inventing Ourselves: Psychology, Power, and Personhood. Cambridge: Cambridge University Press.

Szabolcs, Éva. 2006. “Pedagógiánk... valóban népünk nevelőihez fog szólni.' Az 1956-os balatonfüredi pedagógus-konferencia" ["Our pedagogy will address the educators of people”: Teachers' Conference in Balatonfüred in 1956]. Educatio 3: 609-21.

Szilágyi, János. 1972. "Interview with Ferenc Mérei in the Hungarian Radio." In Borgos et al. 2006, 279-93.

Szondi, Lipót. 1939. “Beszámoló a M. Kir. Állami Gyógypedagógiai Tanárképző Főiskola Kórtani és Gyógytani Laboratóriumának 1938. évi munkásságáról” [Annual report of the Pathological and Therapeutic Laboratory of the Hungarian Royal National Teacher Training College for Special Education in the year of 1938]. A Jövö Útjain 14, no. 1-2: 3-5.

Vikár, György. 1997. "György Júlia és a 'Faludi” [Júlia György and "the Faludi”]. In György Júlia emlékkönyv [In memoriam Júlia György], edited by Györgyné Horányi, 17-20. Budapest: Fővárosi Pedagógiai Intézet és Nemzeti Egészségvédelmi Intézet.

Zibolen, Endre. 1989. "Mérei Ferenc a Balatonfüredi Pedagógus Konferencián” [Ferenc Mérei in the Pedagogues' Conference in Balatonfüred]. In Mérei Ferenc emlékkönyv [Festschrift for Ferenc Mérei], edited by Emőke Bagdy, Péter Forgács, and Mária Pál, 85-88. Budapest: MPT Animula Egyesület. 



\title{
Remembering the Reinstatement of Hungarian Psychology in the Kádár Era:
}

\section{Reconstructing Psychology through Interviews}

\author{
Dóra Máriási
}

In the early 1950s, several fields of psychology were suppressed in countries behind the Iron Curtain as Stalinism accused them of being "bourgeois sciences" (Kovai 2016). After the death of Stalin, the political repression of Hungarian psychology diminished, and the discipline showed a gradual comeback (Bodor, Pléh, and Lányi 1998; Szokolszky 2014) through the reinstatement of the scientific field. Following the path of critical researchers (Harris 2009; Parker and Shotter 2015), who challenge the traditional histories of psychology that pretend to be objective and highly intellectual, I argue that the impact of psychology's reinstatement during the Kádár era can only be understood through the specific political context and personal relations, which were mostly masked in earlier sources that touched on this period. Relying on in-depth interviews with academics of the period, the story of reinstatement becomes highly subjective, and divergent ideas on the role and future of psychology appear in line with power relations in the politicized scientific field. Consequently, the success of a disciplinary field and the position of institutes will be analyzed with special attention to personal and political networks that defined them. This chapter reveals the patterns of the politicization of Hungarian psychology's reinstatement on three levels: the evaluation of professional relations, the definition of what real psychology is, and institutional circumstances.

The first part of the chapter introduces the history of reinstatement and the earlier events that led to that period based on material from ear- 
lier psycho-historical writings. The second part evaluates the characteristics of these texts, and then provides a new perspective for understanding this chapter of Hungarian psychology better, arguing that the process of the discipline's reinstatement was highly politicized. Afterwards, an analysis of politicization is elaborated based on in-depth interviews.

\section{On the Way to the Reinstatement of Hungarian Psychology}

This chapter focuses on a specific period of the history of Hungarian psychology, sometimes referred to as the reinstitutionalization (Kovai 2016), the period of gradual comeback (Bodor et al. 1998; Szokolszky 2014), or as the revival of institutional, scientific, and professional psychology (Koncz and Pataki 1993). This period can be traced back to between the late 1950s and mid-1970s, when the main disciplinary pillars of psychology were established.

To present the history of reinstatement, I have relied on earlier psychohistorical writings by different authors who do not specifically focus on this period and on interviews I collected that, in some cases, overlap in terms of the perspective. Existing psycho-historical writings documenting-evaluating, presenting, or analyzing - the period are either the works of contemporary professionals (Gegesi Kiss 1960; Pataki 1977) or they are retrospective reports, typically produced decades after the events recalled by representatives of different generations (Bodor, Lányi, and Pléh 1998; Hunyady 2006a, 2006b; Koncz and Pataki 1993; Pataki 2002; Pléh 1998a, 1998c; Szokolszky 2014).

Although using different terms, every approach draws a similar timeline of events beginning with a development, followed by a regression, until a turning point when progress begins again. This means that after World War II, there was a short period of progress registered parallel to the re-organization of a democratic society. As Kovai (2016) points out, psychological knowledge was used as a scientific tool for the modernization of society between 1945 and 1948, for instance, in mental-hygienic services, pedagogy, childcare, and education. It had direct institutional consequences as new institutions, such as the National Pedagogical Institute, were founded, which became sites for progressive professional work. ${ }^{1}$ However, some important

${ }^{1}$ The National Pedagogical Institute was led by Ferenc Mérei, and its aim was to support extensive educational reforms, provide career guidance, carry out studies on children, and establish the basis for new text/school books. 
psychological institutions had been established before the short transitional year. The Institute of Child Psychology, founded in 1902, acquired a complex profile of applied psychology providing children with psychotherapy, career counseling, diagnostic activities, and carrying out developmental research, complemented by non-psychological activities such as physiotherapy, pediatric services, and speech therapy (Dancs 1977). ${ }^{2}$ In 1928, the first issue of the leading psychological journal, Magyar Pszichológiai Szemle (Hungarian Psychological Review) was published, and in the same year the Hungarian Psychological Association was founded. ${ }^{3}$ The first university psychological institute was founded in Szeged in 1929. Péter Pázmány University in Budapest established a psychological laboratory as part of the Institute of Philosophy as late as 1936 (Hunyady 2006b). ${ }^{4}$ Although psychology acquired university status, and psychological research and courses were officially present in the higher educational system, neither of these psychological institutes became independent departments and/or faculties offering full degrees in psychology. Yet, this period until World War II can be considered as a period of continuous institutionalization for psychology.

World War II was a dramatic break in the progress of the profession. Psychologists with Jewish roots fled the country (e.g., Lipót Szondi, Michael Bálint), while others were killed by German Nazis or their Hungarian allies. In the first few years after the war, a radical reorganization of the political and cultural field took place. On one hand, these changes seemed promising to many people; those who had close connections to the old conservative or

2 The Institute of Child Psychology operated with this diverse profile starting in 1928. In 1955, after some years of existential uncertainty, the institution was integrated into the Hungarian Academy of Sciences, a network of academic research institutes. By the 1970s, the applied and counseling services of the Institute were gradually removed from the Institute's scope of activities. In 1965, the Institute of Child Psychology was renamed the Institute of Psychology, and it was profoundly reorganized to concentrate solely on basic psychological research. A forthcoming publication, Dóra Máriási and Ferenc Erős, “The Institutional History of Hungarian Psychology after 1945,” covers this topic.

3 The correct title of the journal was Magyar Psychologiai Szemle until volume 16, published in 1947. In 1960, the name and spelling was changed to Magyar Pszichológiai Szemle in volume 17.

${ }^{4}$ When the psychology department was founded, it used to belong to Péter Pázmány University in Budapest, the name of which was changed to Eötvös Loránd University (ELTE) in 1950. 
with the extreme right regimes had been compelled to leave the country. ${ }^{5}$ Kovai (2016) explained that during the years of transition, psycho-studies participated in the societal transformation in Hungary and contributed to actual political decision-making. Between 1945 and 1948, only a few fields of psychology had been institutionalized: state interventions and regulations mostly focused on pedagogy, childhood studies, and national education (Kovai 2016).

After a short democratic interval between 1945 and 1949, psychological knowledge was no longer favored and ceased to be considered useful for the management of society. Certain fields of psychology became targets of politically motivated ideological attacks such as psychoanalysis, psychometrics, and pedology (Kovai 2016). One prominent "victim" of the ideological "paybacks" was Ferenc Mérei (1909-1986), a loyal member of the communist party who could not defend himself and the National Pedagogical Institute from accusations of propagating bourgeois ideas. In 1950, following the methods of the Russian pedology-affair in the 1930s, he was dismissed from his leading position, and meanwhile, the National Pedagogical Institute was also eliminated. ${ }^{6}$

There are several parallel expressions in the psycho-historical texts to describe the subsequent years of psychology's oppression. Pataki (1977) referred to these approximately ten years as psychology's "exile in the desert," while others (Bodor, Lányi, et al. 1998; Kovai 2016) argue that this period was marked by the oppression of the discipline. Despite the seemingly common characteristics of the interpretations of that era, there are important distinctions: there is no consensus among the authors as to whether psychology as a discipline faced repression or just specific branches (Máriási 2016). To

5 This was the case with Pál Harkai Schiller (1908-1949), a talented experimentalist, who immigrated to the United States in 1947 leaving his position at Pázmány University, where he had organized a Psychological Institute.

6 Pedology, the study of children's behavior and development, can be described as a science incorporating the tools of developmental psychology and theories in pedagogy (Kovai 2016). After the Russian revolution, pedology turned out to be very promising in the societal mobilization, and it was strongly supported by a large number of progressive professionals such as psychologists, pedagogues, psychiatrists, etc. But soon, when Stalin gained power, pedology was no longer seen as a beneficial technique for modernization, but as an ideologically suspicious element that did not fit into Stalinist scientific plans. Briefly, those who pursued pedological activities were gradually discredited and removed from their leading positions. All of the newly established institutions and journals were eliminated, and as a final step, pedology was officially banned in 1936 after a special decree of the Central Committee of the Communist Party. 
investigate what happened to the previously mentioned institutions in the 1950s, it is helpful to identify certain patterns.

First of all, institutions, such as the National Pedagogical Institute, were abolished and never reestablished. ${ }^{7}$ Others, like the Magyar Pszichológiai Szemle, ceased publication after 1948, but were relaunched in 1960. From 1960 on, scholars could assemble in an academic platform, an important development, since for almost ten years psychologists had had no way to publish their research and studies in their own professional journal, and there had been no such professional platform to meet, discuss professional issues, and engage in professional debates. In the meantime, a volume of Pszichológiai Tanulmányok (Psychological Studies) released ten years worth of unpublished articles before Magyar Pszichológiai Szemle was relaunched (Gegesi Kiss 1960). The Hungarian Psychological Association met the same constraints, and was dissolved between 1949 and 1960. A third set of institutions was allowed to operate during these years, but not without political pressure. For instance, reports and letters (Dancs 1977) written by Imre Molnár, ${ }^{8}$ the director of the Institute of Child Psychology of the Hungarian Academy of Sciences, show that he made efforts to conform to political expectations. He used obvious elements of propagandistic language (e.g., "socialist morality"), and the institutional goals and activities were adjusted to the norms of the socialist regime: making professional contacts with Soviet colleagues became important; research projects focused on the ideological education of children; discussion of the difficulties of studying Russian at schools; and also the expansion of higher education to working class and peasant children. Similarly, the psychological faculty at Péter Pázmány University in Budapest was maintained, though with very few faculty members. Directors of both institutions seemed very aware of the political threat, and cautious steps were taken to avoid becoming ideologically suspicious. Smirnov's report on the TwentyFirst Soviet Communist Party Congress introduced the official directive that psychology must participate in the construction of communism (Szmirnov 1960). This article was direct proof of how the political atmosphere had changed in favor of psychology, which was no longer considered a Western

7 Ferenc Mérei-who had received a national honor, the Kossuth Prize, for his educational achievements in 1949-and his colleagues were immediately fired from their positions and excluded from the communist party (Kovai 2016).

8 Imre Molnár (1909-1996) was director of the Institute of Child Psychology between 1948 and 1965. 
scientific tool but a science that has to be reformed to fit a socialist society's standards. As Etkind $(2012,4)$ formulates it, the "academic psychology in the Soviet Union ...., from the start, was entrusted with the political task of building the 'New Soviet Man'-a model personality suitable for a future socialist society." Smirnov's report can be read the same way: this document marked the path of Hungarian psychology's reinstatement according to the Soviet scientific program serving higher, political interests.

\section{Psycho-Historical Writings through a Critical Lens}

In the analysis of the aforementioned psycho-historical writings, some seemingly marginal characteristics should be taken into account. The year of publication and the status of the writer are highly important elements in how the reinstatement was evaluated. The reflective position of the writers is seldom revealed to the reader, meaning that the authors do not occupy a critical position reflecting on their own approach, and they do not express their awareness of how their professional status, scientific preferences, and other factors could shape their interpretations. However, further investigation can show that they were-especially in the case of contemporary sources-written by people in positions of power, who reported on the developments in psychology and stated their significance, creating the memory of reinstatement.

Politics appear as an external factor in several articles describing the reinstatement (Bodor, Pléh, et al. 1998; Hunyady 2006a, 2006b; Koncz and Pataki 1993; Pataki 1977, 2002; Pléh 1985, 1998a, 1998b, 1998c; Szokolszky 2014), which is distant from, or even contradicts professional attitudes. Except for some specific, well-known examples of professional careers under political pressure, e.g., Mérei's story, the psychological platform is often presented with scientific autonomy and politically uncorrupted disciplinary positions. The title of a study, selected to comment on and orient a collection of memoirs written by a generation of psychologists, clearly depicts the discipline as the victim of Hungarian history (Máriási 2016): “The Oppression and Rebirth of a Social Science: the Fate of Hungarian Psychology in the Light of Individual Fates, 1945-1970" (Bodor et al. 1998, 303).

Furthermore, unclear, blurred allusions, and atmospheric descriptions can be found in the texts without any clarification to readers who may not be familiar with the internal professional and personal dynamics. Pléh (1998c) described a symbolic dichotomy in the psychological discipline sup- 
ported by hidden political implications and research in a period when a central force preferred, as he puts it, a "special symbolic system." According to him, classical (Pavlovian) conditioning provided a passive image of human beings, as opposed to instrumental (Skinnerian) conditioning which can be closely related to the Western worldview of people who are driven by motivations and active exploration. Similarly, in social psychology, spontaneous, emotionally based group formation stood against the formal, top-down model of group formation (Pléh 1998). This dichotomic image with the two scientific approaches, two different worldviews, and hence two different political preferences represented the group dynamics in the academic field in an abstract language. The utilization of a symbolic language prevented the author to face the personal nature of the tensions, or to state directly the internal conflicts.

Allusions and atmospheric descriptions-along with "reading between the lines" - can be regarded as typical characteristics of language in dictatorships. Koncz and Pataki (1993) evaluate the process of reinstating the discipline, while picturing the scientific atmosphere by hinting at the internal dynamics intertwined by politics without providing any clear references. This language, full of subjective elements, is open to further speculations, especially for those readers who are not included in these academic circles, therefore cannot be familiar with the hidden and exact meaning of the allusions. Certain fields-such as depth psychology, social psychology—-had to engage into ideological battles, which led to "self-apologetic tendencies and forcedformal Marxist interpretations" (Koncz and Pataki 1993, 103). The professional community was parted between experimentalists versus theoreticians, who despised each other. Those who represented expertise and professional scientism became disadvantaged. As actions expressing social critics strengthened, political actions appeared-for instance, petitions-and questions about social psychology's critical role in relation with its social position emerged. Koncz and Pataki (1993) interpreted this ideological overtone as the discipline's defenselessness. ${ }^{9}$ According to them, it was problematic that people's public, political, and professional roles were considered identical.

Koncz and Pataki's argument leads us to another characteristic identified in the psycho-historical writings, which is the image of a fair and independent science. Pléh (1998a) articulated a similar criticism or skepticism

9 After "the liberation" (1947), a Marxist claim was articulated (Pataki 1977). 
of the general phenomena in Hungarian psychology, which called on the duty of social responsibility stating that the mission of psychology is to cure societal harms and illnesses through individuals. In his point of view, this tendency of Hungarian psychology did more harm than good as prophetic utopias became negative images when exactly by the same reason-which is "overpoliticitation"-finally they became rejected. Yet, he remained equally critical of psychologists' belief in naïve scientism that an autonomous, objective science complying with professional standards-instead of obscure ideologically and politically motivated prescriptions-could be the cornerstone of progression (Pléh 1998c). According to him, scholars ultimately believed in the sixties that they are on the right side, facilitating real progression, and in a way intellectually rebelling against the official authorities. So we can conclude that Pléh suggested that even with the different scientific and ideological approaches, psychologists were driven by "virtuous" and pure professional motives.

\section{Politicization of Psychology}

This seemingly defensive attitude that is for instance detected with Pléh, prevents us from realizing that there were no real outsider positions to politics, and psychology's history in the reinstating years should be unfolded through another lens as well, to see how politics structured the professional field in which scholars were active members with complex roles instead of only occupying "victim, martyr, or revolutionary roles" in the communist regime.

However, politicization is not highlighted in the previously cited texts and is not understood as a pervasive factor; political implications are found only in reference to certain actors. While Mérei's professional and political role is well documented and thoroughly analyzed (Borgos, Erős, and Litván 2006; K. Horváth 2011; Pléh 1998b), other representatives remain barely visible. For instance, the aforementioned representative, Pál Gegesi Kiss (1900-1993), appears as the initiator of Hungarian psychology's reinstatement because of his work re-launching the Magyar Pszichológiai Szemle (Máriási 2016), but for instance Pléh (1998b) mentions his name only once in a list. It is Kovai (2016) who describes his role in the reinstatement with more careful attention, yet Gegesi Kiss's role can be further analyzed in relation to academic psychology. Gegesi Kiss was a prominent member of medical academic circles, and as a director of a pediatric clinic, he was regarded as 
a patron of child psychology and psychoanalysis. ${ }^{10}$ He held a favorable status as a prestigious medical doctor and possibly because he built up a political network, which made him a convenient representative of the reinstatement for the political authorities (Máriási 2016). In the opening volume of Magyar Pszichológiai Szemle in 1960, he listed events in the mid-1950s through which he helped psychology's reinstatement case to evolve, but refrained from going into details as to why it had been shunted aside.

Another key figure of this period was Lajos Kardos (1899-1985), the head of the psychology department at Péter Pázmány University, later renamed Eötvös Loránd University. Under his direction, psychological education was sustained even in the most hostile years. Many of his colleagues explained his enduring presence at the university by his professional ability and apolitical attitude, and saw him as "the guardian of professional continuity" (Hunyady 2006a). He sought to avoid conflicts with the political authorities, and stayed away from ideologically suspicious scientific topics and questions (e.g., as a researcher in animal psychology he was on a firm ground). His avoidance and apolitical attitude can be paradoxically understood as signs of politicization, because his orientation was fundamentally defined in comparison to the political atmosphere.

As a final example, Gegesi Kiss (1960) called on the members of the newly established Psychological Committee, ${ }^{11}$ which was founded to organize and supervise scientific activities, to make decisions about the subventions of the Institute of Psychology in the Hungarian Academy of Sciences and its subcommittees, the latter of which were responsible for determining the direction(s) of research. György Aczél, a high-ranking politician, had a strong influence on the cultural life of the Kádár era, but his role in the reinstatement of Hungarian psychology has not yet been fully explored. ${ }^{12}$ Hunyady (2006a) explains that as the scientific system was centralized in state socialism, Aczél

${ }^{10}$ With his approval, psychoanalytical literature remained accessible for his colleague Lucy Liebermann in the 1950s, when psychoanalysis was ideologically suspicious and publication was neither possible nor available (Kovai 2016).

11 The Social-Historical Department set up a Psychological Committee and stated that psychology is neither purely a social, nor medical science (Gegesi Kiss 1960). Therefore, under Gegesi Kiss's direction, the Psychological Committee was established and operated parallel to the Hungarian Academy of Sciences' Presidency.

12 György Aczél (1917-1991) was a deputy minister of cultural affairs from 1958 to 1967. In 1967, he became the secretary of the party's central committee, a position he held until 1974. He had strong informal power in Kádárism’s cultural life. 
had direct influence on the reformation of the Institute of Psychology of the Hungarian Academy of Sciences. ${ }^{13}$

\section{Politicization in the Interviews}

Unlike the texts I cited earlier, I argue that the reinstatement of Hungarian psychology is to be viewed on the stage of political and personal relations. Ferenc Mérei, Pál Gegesi Kiss, Lajos Kardos, and György Aczél are important figures, but they are only few examples of the politicization of the psychological field. The documents mentioned above implied politicization through these representatives who were all in central positions, but most of these people's influence still remains hidden and needs to be more deeply investigated so as to reveal new dimensions, including other sources. Moreover, the question is not only whether we get sufficiently broad or deep insight in the aforementioned figures' activities, but also whether we can include other, perhaps less dominant or prominent participants in the analysis. It is highly important, as the focus on these few pivotal persons' personality and acts would make us believe, that the processes and effects of politicization can be fully revealed through their stories. Therefore, unspoken and unknown internal professional dynamics can be left untouched. However, it is precisely these stories of less exposed representatives and hidden professional dynamics that equally belong to the history of reinstatement.

Instead of distancing the sensitive issues of reinstatement from the present and placing them fully in the past, I argue for the need to broaden the scale of the investigation to other professionals, in order to gain more complex insight into the characteristics of the politicization of the discipline's reinstatement process. Pléh (1998b) suggests that the "political winners" always have interest in obscuring the past. He pointed to a contradiction: between 1958 and 1975 psychologists did not cite living Hungarian psychologists; however, they did choose role models among them. From a different aspect, we might suspect that the past is also obscured and distanced (from the self)-even unintentionally-when earlier authors choose only a few exam-

${ }^{13}$ It is probable that his name in the subcommittee meant no more than a political legitimization of the ongoing re-organization of the discipline, and he lended prestige to the process. 
ples to describe politicization without including their own direct experiences, roles, and the professional milieu of which they were part.

Complexity and a pluralist perspective can be gained by the application of in-depth interviews with psychologists, as every one of them had the opportunity to construct their own history of reinstatement. In previous documents and reports (Gegesi Kiss 1960; Hunyady 2006a, 2006b; Koncz and Pataki 1993; Pataki 1977, 2002), only those scholars who held high positions evaluated and interpreted the process, and by that point they were entitled to shape the representation of the reinstatement. However, interviews with people involved in the reinstatement, but who held different, sometimes lower positions, can reveal patterns and factors that were unnoticed in earlier psycho-historical reports. Furthermore, personal roles may appear in these texts, and other, less dominant interpretations are emphasized. Thus, the memory of the reinstatement becomes a democratic and collective process.

Table 1 General information about the interviewees

\begin{tabular}{|l|c|c|l|}
\hline \multicolumn{1}{|c|}{ Gender } & Year of graduation & Place of university & \multicolumn{1}{|c|}{ Studies } \\
\hline 1. woman & $1945-1950$ & Budapest & psychology-political economics \\
\hline 2. man & $1949-1953$ & Moscow, USSR & psychology-pedagogy \\
\hline 3. man & $1959-1964$ & Budapest & special education, psychologist \\
\hline 4. man & $1960-1965$ & Budapest & history-psychology \\
\hline 5. woman & $1960-1965$ & USSR & psychology \\
\hline 6. man & $1964-1969$ & Budapest & psychology-linguistics \\
\hline 7. man & $1964-1969$ & Budapest & psychology-biology \\
\hline 8. man & $1965-1970$ & Budapest & psychology-literature \\
\hline 9. man & $1969-1974$ & Budapest & medical studies, psychology \\
\hline
\end{tabular}

The research consists of eight in-depth interviews based on the interviewees' personal career paths, and one semi-structured interview, in which the interviewee refused to disclose his personal history and preferred to focus on mainly the professional and general level of the reinstatement. Two women and seven men participated. Seven of them attended university between 19451974 in Budapest, but two of them studied in the Soviet Union. The sample 
contained participants who held different positions. It was important to interview dominant actors, even if they already had more opportunities to express their opinions in written texts, as they had more insight on the key issues of reorganization, and some of them even participated in the processes of decisionmaking. Additionally, I expected that in the context of an interview, their personal stories and views would be emphasized, which had generally remained excluded from articles. In the selection of participants, the other purpose was to include psychologists in non-leadership positions, so as to add new perspectives to the history, with the likely outcome that their responses would both question and complement more dominant figures' statements. In the beginning of the reinstatement period, the participants were either graduated professionals or psychology students and junior associates in different psychological fields. By the time of the interviews, held between 2013 and 2015, they were either retired or senior scholars. However, they had certainly different career paths, but the common denominator is that they all belonged to major institutions (such as the Institute of Psychology at the Hungarian Academy of Sciences, the psychology department at Eötvös Loránd University, the National Psychiatric and Neurological Institute, and Semmelweis University). Only one of them studied psychology as her major, the others did not for many reasons: first, at that time, psychology did not exist as an independent major, so participants had to have another major (e.g., political economics). Second, some of the participants obtained another degree earlier, but became either disappointed in their former studies, or became attracted to psychology later on. The interviews took place in different locations depending on the preference of each participant (either at their office, at their home if they were retired, or at a university room that I arranged). They lasted around two hours, and in one case an interview was recorded in two meetings. The shortest interview came in at 42,900 characters, and the longest was 153,700.

The in-depth interviews revealed the political atmosphere and the effects of politicization through the interviewees' (personal) life trajectories. At the beginning of the interview, participants were asked to present their professional career path. Then additional questions were raised about general professional topics or specific issues they might have personally witnessed. Participants were encouraged to comment on certain details and issues that had already been mentioned in previous sessions in order to access to their evaluations and reveal multiple approaches to the same event or development.

Anonymity and sensitivity towards personal, intimate stories became a central element in the interview setting and later in the analysis of the inter- 
views. Some of the interviewees did not want to participate in the research if it meant revealing their name, and some of them admitted they would share a different story with less sensitive details if their name appeared in the published article. Hence, I decided not to reveal the names of any of the participants. However, for those who know this period well enough, some interview details might be more or less identified. On the other hand, for an English-speaking reader or even for an "average" young Hungarian psychologist, these hidden aspects are probably unrecognizable and need to receive some further contextual and demographic information to be able to adequately interpret the story. After all this time, these reactions of interviewees reveal fear, mistrust, and even paranoia about revealing a certain chapter of the past. Moreover, I as a researcher was also invited to collaborate in this field of relations, since I had to deal with the "discreet hiding and truthful revelation of the realities" of the time.

Thematic analysis was used to detect patterns of politicization in the interview materials. Repeated topics, ideas, and elements were extracted from the texts and grouped into patterns, which are interpreted in the next part. Quotes were carefully selected from the rich materials to illustrate and explain the results.

\section{Evaluation of the Professional Network}

In the first place, politicization is detected in the evaluation of the professional network. Interviewees rate their peers or colleagues in terms of their professional competence and skills, their personal relationships, and they refer to each other by different political positions that sometimes changed with time.

Descriptions of the professional network underpin the importance of personal acquaintances and how personal ties affected the professional atmosphere. As it is reported below, a reinstating discipline in progress lacks the formal mechanisms, structures, and rules to control and manage professional relationships; therefore, subjective factors-for instance, emotions, interests, sympathy-played an important role in shaping the Hungarian psychological reinstatement platform.

About 45-50 years ago, psychology used to be a small science: everyone knew the ones who counted. Personally as well. It had disadvantages, because personal interests and impulses or sentiments pervaded important achievements. (Interview no. 2) 
The professional atmosphere was not just full of hope concerning the reinstatement of psychology. Opposing sides in the conflicts show the complexity and variability of positions that it could have been taken, instead of a dichotomic - good or bad; black and white; communist or oppositionistdiscourse. Personal and professional conflicts could easily turn into political threats, as according to some sources, they occasionally did result in political action. One could report a colleague to the authorities for not following the Marxist framework. These excerpts from interviews describe the same conflict between two scholars: Ferenc Pataki (1928-2015), the director of the Institute of Psychology, and László Garai (1935-), the head of the Personality Psychology Department, who both played an important role in the Institute of Psychology in the Hungarian Academy of Sciences. I use this conflict to illustrate the politicization of professional relationships. The interviewees were either members of Pataki's social psychology department or were Garai's colleagues at the personality psychology department. This argument becomes even more significant, since because the two scholars shared the same ideological roots, they could both identify with the Marxist approach, but they went down different paths while seeking ways and means.

Pataki had asked something, and Garai responded, ... Pataki became so upset that he was holding a glass in his hands, he just had a drink from, and while he was grasping it, the glass cracked in his hands. So, I use it to illustrate that there were vibrant tensions between these two men ... when an argument would accidentally begin. They spoke the same languages and yet spoke a completely different language, they had totally different views about how psychology could evolve and become a science. And then Pataki, you know, represented the modern trends of conflict-research as a good pupil. (Interview no. 5)

So well, if we look at the ideological connections, then, the Garai group was dangerous because they would report people, so they would attack with ideological motives, so they reported. I can attest to it. (Interview no. 4)

They used to be in a great conflict and rivalry with Pataki... But Garai was losing, he was not the man of the era. ... Well, I suppose, Pataki was the representative of the cultural politics of late Kádárism and the Aczél direction. But looking back, he represented this direction in a flexible way, although he was a rigid man. And it was a good period 
for the Institute [of Psychology], because he had good connections, he [knew] lots of people. (Interview no. 8)

Critics of colleagues show us that the political system required compromises and gave privileges in return, all of which affected psychology. For instance, securing someone's position influenced the position of the discipline too. Lajos Kardos, who was earlier described as an apolitical character, was required to introduce his doctoral thesis in a Pavlovian framework and strictly avoid human experiments at the university, which can be interpreted as a professional compromise. According to an interviewee, the fact that he participated in the Rákosi trial ${ }^{14}$ meant that he gained protection against political threats.

... Lajos Kardos translated to the English-speaking reporters as a student. ... Rákosi had a good memory and kept it in mind. There was obviously no contact between them later. But that Lajos Kardos was not dismissed from his position and psychology was not totally oppressed, and his suspicious doctrines masked with Pavlovism, yet ultimately Western-doctrines were not banned, this is all in great part because of the role he played at that time. (Interview no. 4)

[Kardos] had nothing to do, he was splendid, he created the opportunity for animal experiments ... he actually made a political compromise when he embraced Pavlovism and represented it somehow. [He was not] ideological in the sense that he did not say Marxist clichés. He regarded psychology as a specialized branch of science, and that is what he taught. (Interview no. 4)

However, we can also see how people with different political preferences supported common professional goals, and finally stood on the same platform.

14 Although the interviewee refers to one Rákosi trial, there were two trials with the same name. Rákosi, as a member of the illegal communist movemen, was brought to trial in 1926 and again in 1935. Rákosi's first trial was linked to a broader jurisdictional process against other communists. The other trial in 1935 was to condemn Rákosi for his participation in the violence of the Hungarian Soviet Republic between 1918 and 1919. Because the first trial received intense attention nationally and internationally, and Kardos was probably a student at that time, it is possible that the interviewee referred to the first trial in 1926. 
Moreover, the following excerpt implies the changing positions of communist persons loyal to the system.

Miklós Kun ${ }^{15}$ had very good connections in the party, once he even had a ministry, and then as all fine people, he had a fall [laughs]... (Interview no. 3)

The investigation of the personal connections, political preferences, and involvement of participants appears to be a sensitive issue, which deeply affected participants' identities. The evaluation of colleagues, the political system, and their own actions has moral implications. It implies that the system exerted political pressure on people, and therefore whether someone could retain his integrity while he was climbing the ladder of success or following his ambitions became a central issue. Participants used different rhetoric to occupy such morally justifiable positions: distancing themselves from peers; distancing themselves from the actual political system and playing the part of the opposition; or distancing themselves from any political issues at all.

... those who were doing psychology applied "citatology"16 under pressure without having any personal connections to it. . . It is not worth dealing with, it was only a typical phenomenon of the age. ... (Interview no. 2)

Well, I wasn't a member of the party, and then... I don't even know, how it happened, I found myself working with Kardos. (Interview no. 1)

Speaking for myself, what made me limited or moderate, or at a certain level oppositionist, was the Russian intervention and oppression, which

15 Miklós Kun worked at the National Psychiatric and Neurological Institute (called Lipót later on) with Ferenc Mérei. Kun, a psychiatrist, had reportedly good, close connections to the communist party, which helped him arrange a position for Mérei at Lipót.

16 Citatology was a term in state socialism meaning that it was obligatory to cite certain scholars, authors who were considered the official ideologists in Stalinism. Ágnes Heller reports it: "I hate quoting; I owe this strong aversion to the times of Rákosi's dictatorship, where most 'theoretical books' consisted of mainly Lenin and Stalin quotations. We called this then widespread practice 'citatology'. I believed that quoting meant to hide oneself behind the back of another" (Heller 2010, 38). 
was unacceptable to a young man, who in this world, you know. (Interview no. 4)

Self-critics and critical reflection upon political preferences are also found. The reference to moral principles indicates that political influences threaten personal and scientific integrity.

But this was not the reason why I was admitted to the university, it is said that I had already been inside before I was admitted, because this is how it was at that time. I was considered a reliable comrade, I was a KISZ-secretary. ${ }^{17}$ (Interview no. 5)

Well, I think, I impatiently took up a bunch of, at that time, fashionable neo-left thoughts.... Yeah. First of all, I wanted to provoke. (Interview no. 8)

In some cases, interviewees express their view that the reinstatement of psychology provided those who were not able to realize their political ambitions with a chance to build a different career:

It might not only have been Mérei who exchanged his political career for psychology.

Everyone. Well, the social psychologists, Pataki for sure. That is for sure. (Interview no. 5)

\section{The Definition of Psychology}

Politicization also appears in the definition of what psychology is. It touches upon methodological questions and the debate about whether Hungarian psychology should follow modern Western trends, or its duty is rather to adopt original, local approaches that better fit the Hungarian context. There were politically approved theories and scientific approaches-such as the aforementioned Pavlovian frame or the Marxist perspective-to create a Soviet

${ }^{17}$ Hungarian Young Communist League (In Hungarian: Magyar Kommunista Ifjúsági Szövetség, KISZ). 
model of psychology aimed at the denial of the former official political position, which regarded psychology as an originally and utterly Western science, thereby provided a good reason to limit and liquidate it. In the interviewees' eyes, reinstatement was an inspiring reform period when new methods, scientific approaches, and theories were implemented. As is seen below, one of the interviewees who studied in the Soviet Union reported scientific upheaval in the Soviet milieu too, which allowed the introduction of Western innovations.

It was a very large reform period back then, when I used to attend university in the 1960s, when Soviet psychology found its way back to itself. So the end of Pavlovism, and the Vigotsky-school and Rubinstein, and then they were killing a bit of each other, there was Muscovite and Leningradian and I don't know. One can hardly see the difference between the two; it has to be looked for intentionally. But it was enough for the killing, a little morsel is always enough for scientific schools to compete, and if people are wise enough, then they can survive. So, it was regarded as a real revolutionary period, and hence we had a teacher who thought that it was time to teach Moreno. (Interview no. 5)

But an original Eastern psychology could not succeed or complement Western traditions. Yet the interviewees spoke highly of certain Russian scholars and results, for there were not sufficient scientific resources to overcome or even to decrease the gap with Western psychology.

Russian psychology was "up shit creek without a paddle," 18 way below the standard to which we could stoop. These fat-assed countrywomen did pedagogical psychology; they looked like cooks. It was horrible! ... So I was at the point that somehow I have to access the Anglo-Saxon literature, but well, there was the Iron Curtain and everything. So it was awfully difficult. It was possible to get one or two better quality journals in English in the mid-1960s, and I could figure out something out of them and from the bibliography. (Interview no. 1)

Some disciplinary fields and research topics required closer connection to Western literature because hardly any Soviet materials were available.

18 Literally "under the frog's ass," meaning "in bad shape." 
I wanted to go to Tbilisi at any price. Not that I was thinking Tbilisi would be the height of the sciences, but that was the only place in the USSR where attitude research was being done. (Interview no. 4)

Following the Western trends, especially those in the United States, meant more than simply accessing new scientific developments. It also meant the application of a scientific attitude and model based on empiricism, positivism, and a neutral scientific approach identified with professionalism. Empiricism seemed to be a great promise for those in Hungary who suffered from the rigid ideological doctrines inside and outside disciplinary boundaries. It cut short the ideological battles about reality, providing "facts" and hard data. Moreover, this way psychology turned towards natural sciences, which, in fact, came to be another form of normativity (which is data-based, statistically approved), gradually replacing the ideological prescriptions behind the Iron Curtain.

Well, this normative and declarative character of pedagogy frightened me and became less and less tenable, and in the first part of the 1960s ... it was not only the reinstatement of Hungarian psychology, but also a very specific turning point in the Hungarian social sciences, which was a radical turn towards empiricism, to reality, to facts compared to ideological declaration. It was [the result] of the lessons, experiences, and partly the personal experiences, partly the beginning of the Kádár's consolidation, so the period when overt repression and the first waves of amnesty occurred. So, when Mérei is released from prison and a specific world is born at Lipót. ${ }^{19}$ In the first part of 1960s, a whole group of social sciences returned from exile. (Interview no. 2)

Under these circumstances that we had at home, it was possible to conduct empirical social research, and in fact with standardized methods. I regarded it as a great opportunity. And this was a general situation

19 Lipót, in its proper name, the National Psychiatric and Neurological Institute, was an emblematic professional establishment in the history of psychiatry, psychology, and psychotherapy between 1898 and 2007. After Mérei was released from prison, he re-started his psychological career there with the permission of the political authorities, as his presence was less of a political confrontation there than in an academic environment. Later, Lipót became the place where he founded clinical psychology with his colleagues and introduced new Western methods. 
for social sciences. Earlier, all that could be said about society were the enouncements of historical materialism. ... In my opinion, the establishment of empirical social research is a very important thing. And I'm happy for having been part of it. (Interview no. 2)

This shift was probably not against the will of Kádár's consolidation, which profited from a scientific legitimization that did not sound ideological. First, scientific progress as part of the armaments of the Cold War was important to the system. The more science progressed, the more stability, expertise, and power the system could attain. Second, a science that does not want to interfere with societal questions and express critiques is harmless or at least not problematic to the regime. That was probably a reason why people, who were loyal to the party, preferred the image of an autonomous science, because this way, politically sensitive professional conflicts-that could have had consequences beyond the psychological platform-could be avoided. Social psychology, which can be regarded as an ideologically sensitive disciplinary field, created a space for intense arguments that visibly marked the institutional structure of the discipline, because the conflicts took place between two departments of the Institute of Psychology at Hungarian Academy of Sciences. People like Ferenc Pataki, who were in leadership positions, could have been held responsible for political troubles and tensions in the academic sphere. As interviews highlight, oppositional political views were expressed in socially critical scientific approaches containing leftist ideologies, sometimes in connection with important social movements sympathizing with the neo-Marxist, New Left political activism in Western Europe (such as the '68 movements).

There used to be thematic debates with attached papers introducing the discussion. ... I had one public debate about social psychology, Marxism, and so on. . . If I want to be exact, I was not keen on '68, when social psychology disguised itself and became the source of ideological or political debates. Let's say, it turned out to be the disguise of oppositional aspirations. This was popular throughout Europe and social psychology was convenient for that. (Interview no. 2)

And it was a real conflict indeed, it was inside the Institute of Psychology: it was between the personal psychology and social psychology departments. We [in the social psychology department] tried to . . . make the first move toward the Western European or North American 
[directions], everyone according to his or her preference. I was personally a devotee of the Americans, which marked my career twice in my life. ... And then there was a conflict [between the two departments in the Hungarian Academy of Sciences] that we advanced nicely and slowly toward a not-so-creative direction, but in my judgment, in the right way, and they to an original path, so what they did was not the imitation of the Soviets, but by referring to them in a strong Marxist sense. This sooner or later turned into a battle, and it had very important fronts. (Interview no. 4)

Well, he is not an empirical mind, and he's been struggling up to now that social psychology is indeed a kind of a measurable science, and he cannot accept that we focus on measurable things. (Interview no. 4)

However, others supporting the alternative movements believed in an original scientific image that can be applied to manage local societal issues. Different from the official scientific program that aimed to avoid unpleasant and real societal investigations, these initiations believed that-especially social-psychology has to respond to relevant questions, as it has the potential to genuinely shape and move society forward, and the automatic, uncritical application of the American model of psychology is not the right way to do it.

Indeed, we just began to think how it was possible to do relevant social psychology in Central Europe. This was the key word: relevant, and what would make it relevant? Pataki did not like this question because he used to say that relevant is anarchistic. (Interview no. 8)

Altogether, not only these visionary views with clear political implications and critics proved to be threatening to the status quo, but other conflicting points were dangerous as well. In the 1960s, Hungarian psychology faced a promising future, while its difficult and reasonably short past with oppression was still very vivid, which meant that the discipline could not create stability. The threat of becoming dependent on pedagogy and the pressure from other older scientific fields, for instance, medical studies, that regarded psychology as inferior to them, strengthened the debates about "what real science is." The need to perform real scientific work created a certain rigidity and dogmatism in the discipline. Those who succeeded in popularizing psychology reported their disdain of colleagues conducting purely scientific research. 
A couple of decades later when I was at the Institute [of Psychology] too, it was the beginning of the 1970s, when [experimentalism] exploded at home, when experiments became the only valid knowledge basis in social psychology. ... And then when the new spirit and new scientism arrived, so this awful war of psychology to become acknowledged as an independent science, and get rid of the titles, such as "the daughter of philosophy" and others, experiment became important because of this. There were some antecedents, as you know, Pál Ranschburg ${ }^{20} \ldots$ and then this new direction defined the positions as well.... And if someone broke out of it, or became different, or went on television, this is what [Péter] Popper ${ }^{21}$ or Jenö [Ranschburg] did, then they became suspicious and were rejected as not scientific [by his colleagues]. (Interview no. 5)

\section{Politicization of Institutional Circumstances}

In the third place, politicization affected institutional circumstances in many ways.

One interviewee was a student in the late 1940s, when party agitators approached her to drop her psychology studies. Then, when talking about the situation at the psychology faculty in Budapest in the 1950s, she explains how, with Kardos, they sensed the restrictions against the discipline.

[E]veryone who claimed to be a psychologist at the university at that time ... was personally approached by an agitator sent by the party, who said he was a psychologist, and he agitated for giving up this ugly psychology faculty ... and to choose three other faculties instead. (Interview no. 1)

As a matter of fact, I loved animals, but sometimes ideas concerning human experiments used to come to my mind, and another, and I always used to approach Kardos to ask if we could do this with people and do that. "Oh, no, don't try that! They'll pick at us." Well, the ideological pressure was awful, I'm not surprised. (Interview no. 1)

${ }^{20}$ Pál Ranschburg (1870-1945) was a medical doctor and the founder of experimental psychology in Hungary and the Institute of Child Psychology.

${ }^{21}$ Péter Popper (1933-2010) was a charismatic figure in Hungarian psychology, who also gained popularity beyond disciplinary boundaries. 
Another detail the interviewee mentions describes the signs of softening at Eötvös Loránd University. Students showing interest in psychology dared to express it overtly and sought opportunities to study psychology and join professional activities.

Sensing the thaw, I suddenly became surprised because three or four people appeared from here and there, once from the literature faculty, other times from pedagogy, or from philosophy, who declared that they wanted to study in the psychology faculty. (Interview no. 1)

Institutions differed in terms of whether they were politically more or less exposed. The interviews highlighted the fact that the psychology faculty of Eötvös Loránd University and the Institute of Psychology of the Hungarian Academy of Sciences were strategic points in the eyes of political authorities. It meant that political credibility played a crucial factor in the employment of scholars, professional activities were controlled, and a Marxist-frame was required.

Anyways, I don't know, due to this, I was really young at that time, but it's said that the research network of the Hungarian Academy of Sciences, it was anyway a kind of a repository of those people who wereeveryone knew-good professionals, but there was some sort of political problem with them. ... [F] or the first time in my life, I didn't even know where the Institute of Psychology of the Hungarian Academy of Sciences was. There was every kind of person at the Institute of Psychology, so there were like highly respected people in their profession, such as Ferenc Lénárd in pedagogical psychology. And then there were those who needed to be placed somewhere, and they established a whole subdiscipline, like Ferenc Pataki for instance. (Interview no. 7)

Political authorities sought to maintain a well-regulated balance through the selection of the leaders and the organization of the institutional structure. For example, those who did not fit well into the political atmosphere of Kádár's consolidation were not always dismissed, but rather pushed into the background by receiving positions without any visible power or authority. This was the case with Ferenc Lénárd (1911-1988) and László Mátrai (1909-1983) for example, who were representatives of the pedagogical and philosophical traditions of psychology. Lénárd was responsible, among others, for editing the Hungarian Psychological Review, which was published under Gegesi Kiss's 
name as a chief editor. The conflict between Gegesi Kiss and Mátrai could be understood as the shifting of power in favor of the former, who was, at that time, in a better political situation. Personal conflicts such as this could have a direct impact on organizational forms. The aforementioned conflict between the personal psychology and social psychology departments was also related to the institutional background. According to some participants, Aczél decided to create balance in the Institute by placing Garai into a newly founded department.

Pataki was punished after '56. Not that much, just a little bit. . . Because of the Petöfi Circle. ${ }^{22}$ And he did not rejoin the party, he wasn't such a good comrade but he had a very good position with Aczél. And yes, they could be worried to a certain degree that Feri (Ferenc) was not good enough. And a balance was necessary. And this is how two parallel departments were founded [at the Hungarian Academy of Sciences], the first was called the social psychology department, and the other, which practiced not much different things [was called personality psychology department]. (Interview no. 5)

So Pataki had an extraordinary role in the ministerial decisions regarding the university, or later universities, when another department was founded in Debrecen. So there always used to be different kinds of committees, this kind of pseudo-democracy, which was invented, and finally it turned out that it was Pataki. (Interview no. 6)

It is considered evident that people loyal to the communist system could receive higher status even with questionable professional skills. It was beneficial to have good personal connections with the party in the organization of the institutions. Ideological reliability in the disciplinary field was sustained by the careful selection of people, and by controlling research topics and the content of lectures. Political interests behind public decisions were often hidden,

22 The Petöfi Circle was a Hungarian intellectual movement founded in 1955, which played an important role in the evolution of the 1956 Revolution. Stalin's death motivated aspirations to eliminate the personality cult and implement reforms in the systems behind the Iron Curtain. Those who participated in the debates of the Petöfi Circle in 1956 could have been later found guilty of cooperation in acts against the communist regime. 
although they were mostly evident to everyone, and the authorities favored discreet negotiations behind the scenes and vocal demonstrations of respect for scientific standards. The following excerpts provide insight on the background of the Institute of Psychology's operations.

Gegesi was certainly important as the [director] at the Child Clinic, and the vice chancellor, and the party's loyal member in the medical sciences. It is very important that he was able to ensure that the Psychological Committee did not belong to any academic departments [of the Hungarian Academy of Sciences], but it operated as an independent department. It was an exceptionally privileged situation. The committees of the scientific divisions used to belong to one of the departments, for instance the Psychological Committee is part of the Philosophical and Historical Department. At that time, it existed as an independent department for a while. (Interview no. 2)

However, as I already pointed out, by the late 1960s and 1970s, the introduction of Western trends was approved, and it was also possible to get scholarships abroad, although only privileged people could obtain scientific trips to Western Europe or to the United States for a while. The reduction of political pressure allowed scholars to deal with professional issues undisturbed and supervising committees respected and supported professional needs.

I outlined the concept of a five-year-long education/formation, of course with the cooperation and approval of the others, and a professional committee was established in the ministry. It was a committee of honorable and good professionals, there were around ten members. (Interview no. 1)

But some well-known events revealed the limits of agency of the psychological discipline. Magda Marton (1924), a highly respected scholar employed at the Institute of Psychology of the Hungarian Academy of Sciences, used to give lectures on personality psychology at Eötvös Loránd University as a guest lecturer around 1966. She was reported by a student for promoting still-prohibited Freudism at the university.

There was a course, personal psychology, and Mrs. Marton was reported to the party for representing bourgeois views, and for propagating bour- 
geois theories, such as Freudism ... so it was a cause, and it finally calmed down, but Mrs. Marton was successfully kicked out. (Interview no. 8)

Some other institutions admitted "problematic characters": ideologically suspicious or potentially reactionary, oppositional people who could be distanced from the public, for instance, away from the university lectern where the official and legitimate knowledge was transferred to the next generation. These people, in fact, remained under control but were permitted to carry on with professional activities that did not carry any political threat.

... this László Gábor Horváth gave lectures, he was a "standard madman." ... He, I guess, was a leader at an aptitude testing center for the Hungarian State Railways. Indeed, the continuity of psychology was ensured by this in practice, besides the university department. He probably had Interior Ministry connections as I can size up subsequently, and it gave him the right to assemble deliberately outclassed people, so these kinds of gentry-like characters. He literally held them captive in humiliating conditions, László Gábor Horváth, but he had an agreement with the universities that three people were admitted per year among his crew. (Interview no. 4)

Sometimes it meant real professional freedom indeed, such as in Mérei's case, who, after his imprisonment, promoted the establishment of clinical psychology working in Lipót.

Psychology as a profession did not exist in that health nomenclature. But there was a university degree ranking.

Now, back then there was a huge difference in wages between the college and university rankings. So we, we were really eager to have a university degree in order to get higher wages, because we all had children and a family, and I don't know. ... But though there was no psychology, there was psychology education at the university, there was a degree in psychology, but there was no psychology as a profession. So the health system couldn't handle our psychology degree. (Interview no. 3)

Different sources confirmed György Aczél's direct influence on the institutional changes. On the one hand, his position allowed him to officially le- 
gitimate control and supervise the reinstatement. On the other hand, personal links with him, or friendship and participation in earlier communist movements could help in advancing someone's professional career with Aczél's permission. These excerpts can only serve as examples of his role in psychology.

Just to take a look into the system's operation, every nomination was signed by György Aczél. This was a really interesting thing, so for someone to become an associate professor, as I once turned out to be at the Faculty of Liberal Arts, the countersignature of György Aczél, as a deputy minister, was necessary. (Interview no. 4)

So well... in my opinion Aczél had indeed-I have never checked it-a mostly positive impact on Hungarian psychology. He had a very close relationship from old times, I mean during the war, before the war with Miklós Kun, and therefore he supported the attitude Miklós represented at Lipót, and he, you know, integrated Mérei there, and it had a kind of balancing, specific role in Hungarian psychology in the 1960s-1970s, and it was a really positive thing to do, and it derived from their, I don't know, communist activism. Because Aczél, well, he used to be a kind of young activist at the end of the 1930s. (Interview no. 6)

Those who were educated in the USSR, sometimes later in life such as members of the working class, for instance a hairdresser, automatically received a job at a time, even when it was difficult for newly graduated psychologists to find a position suited to their qualification.

Lajos Kardos found himself in a really difficult situation because it was very important to employ the students returning from the USSR; this was the agreement. (Interview no. 4)

And well, the best, I tried to maintain the best [at the university]. So I used to spend time in the anterooms of the ministries that I hated so much, the ministry of that time. They said he did not even graduate high school, but he was a good cadre. And I was afraid of them. And there I dared to spend time in the anterooms of the head of department and the main head of department to give him and her research assistant status. (Interview no. 1) 
So at that time there were no positions at the university, you know there was only one place for psychology education, only one place for research, at the institute of the Academy, so when I graduated from the university, I was an unemployed intellectual for half a year and did translation works for the Hungarian Advertiser Ltd. (MAHÍR). (Interview no. 6)

With the thaw, political interest met professional standards. However, though political authorities surveilled and secured professional decisions and circumstances, their intention was in fact not to limit scientific progress.

- But this network of power due to the activities of Miklós Kun, comrade Gál, Béla Mária, Mérei’s actions as a "Spiritus Rector," so this was always a realizable, realized concept indeed, which...

-Okay, so was there anything that was refused?

-No. Nothing. (Interview no. 3)

\section{Conclusions}

This chapter demonstrated that politicization penetrated the reinstatement of the psychological discipline in complex ways. I analyzed patterns of politicization on three levels: interpersonal relationships, professional debates about psychology's role, and institutional circumstances.

While reinstatement offered new opportunities for the organization of the discipline, pervasive politicization in the Kádár era, unclear positions, and hidden motives planted suspicion in professional relations and encouraged the evaluation of peers according to political standards. Because professional institutional mechanisms were not yet organized, informal factors played important roles. Internal conflicts were related to ideological debates as well, and this sometimes created intense tension between scholars. Professional success and career opportunities were located in a political space, which raised further questions about political influence. Interviewees sought to place themselves in politically and professionally "correct" positions. In their narratives, their moral selves were at stake in the creation of an ethical discourse useful for interpreting (their) history.

The ongoing professional debates and psycho-historical articles report constant conflict over the definition of what real psychology is. The struggle for a definition is, in fact, a political act: scientific statements are political too, 
as by expressing professional beliefs, people turned toward or against the official scientific program of socialism. Psychology in Western countries was not only more developed; but it had also created the illusion of ideological freedom, which resulted in the support of a positivistic and individualistic science. The interviews confirmed that reviving institutions meant less constraint and more freedom to build up the psychological field than did the institutions of the 1950s. Yet every institution had more or less visible political control through the scientific programs and carefully selected nominations to key positions that managed all professional operations.

The main goal of this article was to draw attention to the importance of unraveling the political issues that lay beneath the surface of the Kádár-era reinstatement of psychology. Some psycho-historical writings contained allusions to these sensitive topics but refused to express them overtly, sometimes because of personal reasons; at times participants used "unscientific" discourses to distance themselves from this history. However, I argue that all these findings confirm the social constructive aspects of psychology, and prove that psychology evolves in a specific political-historical context that has to be revealed in order to provide reliable scientific answers to human behavior. As the boundaries of the "real science" are highly dubious, and as I demonstrated how the personal and political were intertwined with the scientific directions of institutions, and thus helped shape the psychological discipline in Hungary, it became evident that the politicized personal and professional layers of the reinstatement are integral parts of our collective memory, and therefore deserve greater attention and further analysis.

\section{REFERENCES}

Bodor, Péter, Gusztáv Lányi, and Csaba Pléh. 1998a. "Egy társadalomtudomány elnyomatása és újjászületése: a magyar pszichológia sorsa az egyéni sorsok tükrében, 1945-1970" [The oppression and rebirth of a social science: The fate of Hungarian psychology in light of individual fates, 1945-1970]. In Önarckép háttérrel: Magyar pszichológusok önéletrajzi írásai [Self-portrait with background: Autobiographies of Hungarian psychologists], edited by Péter Bodor, Gusztáv Lányi, and Csaba Pléh, 303-19. Budapest: Pólya Kiadó.

—_ , eds. 1998b. Önarckép háttérrel: Magyar pszichológusok önéletrajzi írásai [Selfportrait with background: Autobiographies of Hungarian psychologists]. Budapest: Pólya Kiadó.

Borgos, Anna, Ferenc Erős, and György Litván, eds. 2006. Mérei élet-mü. Tanulmányok [The Mérei oeuvre: Studies]. Budapest: Új Mandátum. 
Dancs, István, ed. 1977. 75 éves a Magyar Tudományos Akadémia Pszichológiai Intézete: Dokumentumok és beszámolók [75 years of the Institute of Psychology of the Hungarian Academy of Sciences: Documents and reports]. Budapest: MTA Pszichológiai Intézete.

Etkind, Alexander. 2012. "Psychological Culture: Ambivalence and Resistance to Social Change." Russian Culture. Available online at http://digitalscholarship.unlv.edu/ russian_culture/5/.

Gegesi Kiss, Pál 1960. "Bevezetö” [Introduction]. Magyar Pszichológiai Szemle 17, no. 1: $1-9$.

Harris, Ben. 2009. "What Critical Psychologists Should Know about the History of Psychology." In Critical Psychology: An Introduction, edited by Dennis R. Fox, Isaac Prilleltensky, and Stephanie Austin, 20-35. London: Sage Publications.

Heller, Ágnes. 2010. A Short History of My Philosophy. New York: Lexington Books. Hunyady, György. 2006a. "A budapesti tudományegyetem és a pszichológia” [The Budapest University and psychology]. In A szociálpszichológia történeti olvasatai [Historical aspects in social psychology], edited by György Hunyady, 187-98. Budapest: ELTE Eötvös Kiadó.

— . 2006b. "Hetvenöt év és a magyar pszichológia." [75 years and the Hungarian psychology]. A szociálpszichológia történeti olvasatai, edited by György Hunyady, 199-213. Budapest: ELTE Eötvös Kiadó.

K. Horváth, Zsolt. 2011. "Kívül: Peremhelyzet és a habitus formálódása Mérei Ferenc élettörténetében" [Outside: Marginality and habit formation in Ferenc Mérei's life history]. PhD dissertation, Budapest: Eötvös Loránd University.

Koncz, István, and Ferenc Pataki. 1993. "Az Akadémia Pszichológiai Intézete" [The Institute of Psychology of the HAS]. Magyar Tudomány 38, no. 1: 99-108.

Kovai, Melinda. 2016. Lélektan és politika. Pszicho-tudományok a magyarországi államszocializmusban 1945-1970 [Psychology and politics: Psycho-sciences in the Hungarian state socialism, 1945-1970]. Budapest: L'Harmattan.

Máriási, Dóra. 2016. "Amikor a pszichológia a 'kommunizmus általánosan kibontakozó építésének nagyszerü programjához’ csatlakozott” [When psychology joined the "glorious program of building communism." Reinstitutionalization in a critical perspective]. Alkalmazott Pszichológia 16, no. 1: 63-79.

Parker, Ian, and John Shotter. 2015. Deconstructing Social Psychology. Vol. 21. Oxford: Psychology Press.

Pataki, Ferenc. 1977. “A magyar pszichológia történeti útjának néhány időszerű tanulsága" [Some actual lessons from the historical path of Hungarian psychology]. Magyar Pszichológiai Szemle 34, no. 6: 563-86.

— . 2002. "Egy évszázad árnyékában: Adalékok a Pszichológiai Intézet történetéhez" [In a century's shadow: Contributions to the history of the Institute of Psychology]. In Az általánostól a különösig [From general to peculiar], edited by István Czigler, László Halász, and Magda Marton L., 15-41. Budapest: Gondolat Kiadói Kör-MTA Pszichológiai Kutatóintézet.

Pléh, Csaba. 1985. "Társadalmi változások és a pszichológia négy évtizede" [Social changes and four decades of psychology]. Világosság 26: 212-18.

— . 1998a. "Hagyomány és újítás a magyar pszichológiában" [Tradition and innovation in Hungarian psychology]. In Hagyomány és újítás a pszichológiában 
[Tradition and innovation in psychology], edited by Csaba Pléh, 59-65. Budapest: Balassi Kiadó.

_ 1998b. "Magyar hozzájárulások a modern pszichológiához" [Hungarian contributions to modern psychology]. In Hagyomány és újitás a pszichológiában, edited by Csaba Pléh, 71-90. Budapest: Balassi Kiadó.

_ 1998c. "A pszichológia szimbolikája egy slampos totalitárius rendszerben. A magyar pszichológia a hatvanas években" [The symbolic of psychology in a loose totalitarian regime. Hungarian psychology in the 1960s]. In Hagyomány és újitás a pszichológiában [Tradition and innovation in psychology], edited by Csaba Pléh, 91-111. Budapest: Balassi Kiadó.

Szmirnov, Alekszej Alexejevics. 1960. "A pszichológia feladatai az SZKP XXI. kongreszszusa határozatai tükrében" [The tasks of psychology in the mirror of the resolutions of the XXI. Congress of the CPSU]. Magyar Pszichológiai Szemle 17, no. 2: 129-52.

Szokolszky, Ágnes. 2014. “Hungarian Psychology in Context: Reclaiming the Past.” Hungarian Studies 30, no. 1: 17-56. 

PART FOUR

\author{
The Politics of Psychiatry: \\ Bodies, Illnesses, and Mental Health
}





\title{
The Hygiene of Everyday Life and the Politics of Turn-of-the-Century Psychiatric Expertise in Hungary
}

\author{
Emese Lafferton
}

\section{Shifts in the Social Functions of Psychiatry by the Turn of the Century}

Characterized by diverse social composition as well as political and ethnic conflicts, late-nineteenth-century Hungary provides the exemplary model of the coexistence of fierce nationalism and fervent cosmopolitanism. The interaction of these forces deeply shaped the country's medical and human sciences. Manifestations of a perceived degeneration within "civilization": capitalism, socialism, feminism, anarchism, the Decadent movement, crime, high suicide rates, and insanity, became signifiers of cultural crisis that contemporary scientists translated into a language of social pathology.

In the following, I focus on psychiatrists' contribution to this process. After the lengthy process of building a professional institutional system in the country starting in the 1850 s, by the turn of the century, Hungarian psychiatry gradually moved beyond its closely defined disciplinary borders and increasingly became a public arena. As this chapter demonstrates, psychiatrists extended their professional expertise, originally focused on the individual person and the patient population within psychiatric institutions, to the larger social domain, encompassing crowds, masses, cities, and the nation. Parallel to this development concerning the health of society, psychiatrists also gradually attained a cultural monopoly over the "hygiene of everyday life" and, by the first decades of the twentieth century, invaded the private spheres of ordinary families and individuals.

These tendencies resulted in what Elizabeth Lunbeck called the "spread of psychiatric perspective" (Lunbeck 1994) in society, unconnected to psychiatric 
institutions. The task of the psychiatrist now was to intervene in solving grave social problems, such as alcoholism, pauperism, prostitution, syphilis, sexual perversion, and insanity; this crystallized in the hygiene of a healthy mental and physical "everyday" life in which prophylactics figured prominently.

\section{Degeneration, Social Problems, and Prophylactics}

The population of psychiatric institutions in the last decades of the nineteenth century suggests a strong connection between grave contemporary social problems and psychiatric illness. The rise of the number of paralytics, alcoholics, and neurasthenic patients (neurasthenia was perceived as an "epidemic") made social factors become ever more relevant in psychiatric thinking (see Lafferton 2006). A proliferation of books and articles by well established psychiatrists on a few topics contained strong social criticism targeting alcoholism, prostitution, pauperism, and the consequences of capitalism and civilizational forces. These social factors and elements of organicism combined in the all-pervasive theory of degeneration to which numerous Hungarian psychiatrists full-heartedly subscribed. ${ }^{1}$

This growing literature produced by psychiatrists with very different backgrounds demonstrates a significant shift and expansion in psychiatrists' understanding of the profession's role and function by the turn of the century. Claims of professional expertise, originally focused more on the individual person and the patient population within the psychiatric institution, was now extended to the larger social domain. The health of society was now at stake, and it was explicitly argued that it was psychiatrist's task to intervene in social problems and solve them with his expertise. Prophylactics became a key concept in turn-of-the-century psychiatry. "Human society reacts to pathological conditions not through the individuals, but as a single body" (Oláh 1903, 50), therefore psychiatry's greatest task was the development of "prophylactics that

\footnotetext{
${ }^{1}$ Degeneration theory had been first systematically described by French psychiatrists J. Moreau de Tours (1804-1884) and Augustin Morel (1809-1873), later popularized by Paul Möbius (1854-1907) and the Hungarian-born Max Nordau (1849-1923), and was widely accepted by psychiatrists by the last third of the nineteenth century. On the medical concept as well as the rich social meanings of degeneration, see Pick (1989); the relevant essays in Chamberlin and Gilman (1985); Nye (1984); and Bynum (1984).
} 
encompasses social life and extends to several generations" (Oláh 1903, 22, also 60). Prophylactics became increasingly important in numerous psychiatric works that placed more emphasis on aspects of healthy living and constructed the hygiene of a healthy mental and everyday life. ${ }^{2}$

From among the numerous examples, the mental pathologist and asylum doctor Károly Lechner's argumentation nicely illustrates this "new mission" of the psychiatrist and introduces most of the topics that are discussed in detail below. $^{3}$ At the 1902 Second National Congress of Psychiatrists, and in a Darwinian vein, Lechner discussed in detail three of the most dangerous factors in the "struggle for existence and race preservation": alcoholism, syphilis related to prostitution, and "pauperism," all of which resulted in the mind's exhaustion $(1903,118)$. In his argument, alcohol, prostitution, pauperism, and crime interact in a vicious circle, tied together by the concept of degeneration. "The abuse of alcohol leads to the degeneration of the organic structure and the psychic character, and to early death.... But its greatest curse is that the degeneracy of the alcoholic's cerebrum is passed down for four generations within the family." Likewise, "prostitution generates syphilis, syphilis generates degeneration that thrusts many into prostitution, into vice, others into alcoholism, again others into insanity due to paralysis progressiva or tabes dorsalis.... Paralysis, inflicting a quarter of all the mental patients, attacks its victims in the prime time of their manhood, ... it begins with an early moral blindness, and destroys whole families before it kills the patient" (Lechner 1903, 119).

The solution is not simply what characterized earlier psychiatric belief: the patient's cure through individualized treatment. What the new solution added to this is intervention on the social level, the elimination of the social roots of mental illnesses implemented with the psychiatrist's expertise. "To stop the quick further spreading of paralysis progressiva throughout the country can only be achieved by the overall reform of prostitution. In this, the psychiatrist has to give a helping hand" (Lechner 1903, 120).

Similarly, in cases of pauperism and poverty, which, according to Lechner, directly affect the brain but also bring with it parasitism, work

2 From this rich literature, see, for instance, Donáth (1894); Salgó (1896, 1903, 1910); Epstein (1903, 1908a, 1908b); and Oláh (1903).

${ }^{3}$ Károly Lechner (1850-1922) was a mental pathologist, chief doctor of the Schwartzer private mental asylum, later became the director of the Angyalföld National Mental Institution. He was an important proponent of reflex-theory. 
avoidance, vagabondism, alcoholism, and vice, all of which predisposes one to mental illnesses and form "the hotbed not only of mental disorders, but dangerous social maladies of anarchism and nihilism," the solution is again intervention on the social level with the active participation of psychiatrists in establishing further public charity institutions and designing better policy aimed at the poor. The psychiatrist no longer poses simply as the master of the deluded mind and nervous disorders, but also as the healer of social maladies. With his expertise, he claims to intervene into the formation of policy towards the poor, and thus improving their living and working conditions, defining the principles of child-rearing, etc., "according to the guidance of the professional psychiatrist" (Lechner 1903, 120-121).

\section{Neurasthenia or Nervous Exhaustion}

Our century has been marked by many kinds of adjectives. The extended use and irreplaceability of iron, the rails that run across the globe, the spread of machines, all would justify our choice to call our century the age of the iron. The wonderful achievements of electricity in the last decades, the telegraph, the telephone, the electric light and rails ... could urge us to see our century marked by electricity. But it does not deserve any designation so much as "nervous."

-Mór Kende $(1898,3)$

Not all mental diseases linked to the nerves had a confirmed anatomical cause. The increasingly "popular" psychic disease of neurasthenia- "the weakness of the nerves"- was said to be a nervous disorder that was manifested in psychic symptoms due to the "pathological excitability and functional weakness of nerve-centres in the cerebral cortex and the sub-cortical area," although its anatomical basis was admittedly unknown (Laufenauer 1899). Yet neurasthenia or "nervousness," like the vapors and the spleen of the eighteenth century, became omnipresent in society. ${ }^{4}$ Nervous disorders were perceived as epidemic, and "nervousness" became a rich and pervasive social metaphor for the whole age.

4 From among the numerous works on the subject, see Fischer (1892); Sarbó (1894); Takács (1895); Donáth (1895); and Schaffer (1896). 
Similarly to Lechner, the mental pathologist and asylum doctor Jakab Salgós argumentation in his 1905 book A szellemi élet hygienája (The hygiene of mental life) conceptualizes problems on the social level and defines the psychiatrist's job as no less than "to restore the shaken health of society's organism" (Salgó 1905, 124). Building on theories concerning the chemical processes that underpin mental processes in the central nervous system, as well as on the results of German experimental psychology, in his book, Salgó elaborates on a complex hygiene of mental life with its psychological ramifications. "Modern mental work as well as social life" are the predisposing factors that lead to the overexertion of the nervous powers and result in mental exhaustion. In Salgó's argument, "the character of modern mental work, the contemporary form of the use of mental powers is not only dangerous to the exhausted individual, but endangers society more than any devastating epidemic" (5-29 and 122-30).

Salgós psychologically informed social criticism extended to the "gentlemanly" aspirations and exaggerated needs of the gentry, to the powerful role of the bill of exchange in people's mental life ("how many men's lives have been ruined by the bill!"), and to workers' housing conditions, unsatisfactory nourishment, and low salaries, all of which contributed to the exertion of mental and life powers. Although most of these factors are very similar to those enumerated in the first Hungarian mental pathological textbook written by the alienist Ferencz Schwartzer (1858), by the turn of the century this criticism was espoused with a claim of the psychiatrist's expert intervention in these very social problems.

\section{Paralysis Progressiva}

As asylum doctors, we are used to the fact that every third patient ... with shuffling steps, stuttering speech, and destroyed psyche is the living evidence of the destructions of a horrible disease.

-István Hollós $(1903,14)$

Paralysis progressiva was a particularly serious and devastating form of mental affliction due mostly to the advanced stages of syphilitic infections following a long, sometimes ten-year period of incubation. Once it broke to the surface, it manifested itself in increasingly grave mental and bodily symptoms: 
tremors, foot dragging, muscle wasting, bragging, megalomania, and in the final stages, complete mental derangement.

While there were no statistics concerning the prevalence of paralysis in the entire adult population of the country, paralysis was one of the primary diseases found in mental asylums. Based on a comprehensive sociological survey conducted on patient records in the two largest mental institutions of the country, I analyzed the social and pathological parameters of their inmate population liable to use public services of mental care between $1863 / 1868$ and $1915 .{ }^{5}$ It showed that paralysis progressiva was the second most frequently diagnosed pathology in Lipótmezö, affecting 24.0 percent of all patients (33.5 percent of men and 10.0 percent of women) and the most frequent pathology diagnosed in Nagyszeben, affecting 21.0 percent of the patient population ( 27.7 percent of men and 8.9 percent of women). It indeed hit most of its victims around their forties (men between thirty-five and fortyfive were especially exposed to this due to the ten-year latency period) and its relation to gender is evident: 83.2 percent of the paralytic patients were male in Lipótmező and 84.6 percent in Nagyszeben. Taking the entire male asylum population of the period, every third patient suffered from paralysis in Lipótmező, and their proportion was only slightly less in Nagyszeben (27.7 percent) (Lafferton 2006, 89-90).

The vast gender difference identifiable here with the overwhelmingly male recruitment of paralytics clearly attests to the gende-specific social conditions of the illness. Sexual promiscuity sustained by prostitution provided a feeding ground for the infection of a large number of male clients and a few female victims (hence the marked over-representation of mature men among paralytics). Paralysis progressiva thus not only formed a major professional problem for psychiatry, but also posed grave moral and social questions concerning bourgeois values, prostitution, and the sanctity of the family, and became a lived reality for numerous families that lost a family provider or a brother to the disease and had to face all its social consequences.

Unlike alcoholism, which more often affected the lower classes, paralysis progressiva's victims primarily came from the middle and upper classes. In a presentation for the Second National Psychiatric Congress in 1902 in Budapest, the Lipótmező mental asylum doctor, István Hollós, analyzed the

${ }^{5}$ On the two state mental asylums, that of Lipotmezö (named after the Buda district in which it was founded as the First Royal Asylum), and that of Nagyszeben (today, Sibiu, Romania), see Lafferton 2006. 
current situation of paralysis progressiva in the country and provided data on its prevalence in mental institutions. Compared to the 30-35 percent of paralytics among the mental asylum population, out of one hundred judges brought to mental institutions, seventy-eight were paralytic; out of one hundred lawyers, seventy were paralytic; out of one hundred engineers, officials, actors, pharmacists, etc., fifty to sixty were paralytic; and out of one hundred physicians, there were forty-five paralytics. As opposed to these numbers, out of one hundred peasants brought to the mental institution, only fifteen suffered from paralysis (Hollós 1903, 4, 20). Oláh also connected paralysis to intelligence and mourned the enormous "damage done to the state due to the amount of reason lost mostly as a result of syphilis" (Oláh 1903, 57).

Concerning the cause of paralysis, in 1913 the clinical psychiatrist László Benedek concluded: "paralysis can only arise in someone infected by syphilis, often in the presence of predisposing factors" (Benedek 1913, 243). Although by around 1900 many Hungarian doctors suspected that the syphilitic infection was behind the disease, it was still contested. Hollós, for instance, argued that the syphilitic origin was not yet proved, and hence, he only considered syphilis as one of the frequent conditions associated with paralysis progressiva, just like heredity and "psychic influence" (Hollós 1903, 16-17). In his argument, it was the "psychic element" that was present in the case of all paralytics and which affected the nervous system of humans.

The way the "physical organism has a hygiene, which contains the laws of material life processes as well as of normal and abnormal work," so there must be a set of laws for psychic life, which determine what is "normal" psychic work and what mental activity counts as dangerous which "after a certain duration inevitably leads to disease" (Hollós 1903, 18). Although later a follower of psychoanalysis, Hollós was emphasizing the role of "psychic damages" that affect a person sometimes starting in childhood, which may culminate in disease. In a vague sense therefore, "mental exertion" or "emotional shocks" as psychic conditions of a person may make him or her diseased. Hollós came up with the basic fundamentals of a "hygiene of psychic work" encompassing "everything from elementary sensation to the creation of the genius": the right balance between work and rest. This rhythm of work and rest, present in nature and in physical work, is often disrupted by our life embedded in modern culture, due to the excitement of alcohol and numerous refined pleasures (Hollós 1903, 22-23).

Salgó similarly saw paralysis progressiva as the most extreme form of mental exhaustion and stated that "paralysis is the disease of the intelligence, 
that is, it takes its victims from the ranks of mental workers." Completely disregarding the syphilitic aetiology, he blamed it on the "tiresome, consuming nature" of mental work at the expense of rest. With tables on Lipótmező paralytic statistics, Salgó argued that age, occupation, sex, and marital status all supported the notion that paralysis developed from mental exhaustion (Salgó 1905, 138-140). While most doctors blamed the fact that men generally fall prey to paralysis between thirty-five and forty-five on men's sexual habits and the ten-year incubation period of the disease, Salgó explained it with the sociological burden of founding a family. Salgó explicated the far greater frequency of paralytic men compared to women with men's "five-six times greater mental exertion" in society (Salgó 1905, 140-41).

Salgó, however, observed a recent increase in the number of paralytic women and explained it with social changes: the more intense mental life of the female sex and their struggle for independence, which he believed carried grave dangers. "The louder and louder demands of the female sex, the stronger emphasis on their individual values, ... their war for social and economic independence, and their resulting greater mental exertion all have express signs" not so much in the success of the feminist movement, but in the "speedily increasing number of paralytics" (Salgó 1905, 142).

\section{Alcohol Problems, Class, and Crime}

Our age is the age of alcoholism. The alarming rise in alcohol consumption is the evidence of this.... Our era is the last stop in a vanishing world. It was in our time that the natural principles of individual and racial life became known. These principles undermine the prejudices of a millennium: that for work and the pleasures of life, we need drugs, most of all alcohol.

—István Hollós (1909, 12-14)

The shift in psychiatrists' assumed social role and function is also manifest in the fight against alcoholism. The task was no longer to provide expert help to the individual patient in his recovery from delirium tremens, but prophylactics and intervention on the social level. Psychiatrists' active involvement in the temperance movement can be observed starting in the 1890s in the spectacular increase in publications on the topic in more popular and general journals, such as the Az Egészség (Health), the newly launched Alkoholizmus 
(Alcoholism), Népjólét (Public welfare), Közegészségügy (Public health care), Klinikai Füzetek (Clinical papers) as well as in traditional medical forums like Orvosi Hetilap (Medical weekly) and Gyógyászat (Medicine). ${ }^{6}$

Budapest doctors, medical students, and intellectuals collected signatures and turned to the English Good Templars Order to establish a Hungarian branch. In 1901, the Hungarian free masonic lodge named "Egészség" (Health) (and alternatively referred to as the Good Templars' lodge) was founded by the psychiatrist and Royal Councilor Fülöp Stein and the Lipótmező psychiatrist István Hollós. ${ }^{7}$ Its chief task was the organization of an anti-alcohol movement. The $10^{\text {th }}$ International Anti-Alcoholism Congress organized by Stein and held in Budapest in September 1905 was probably the largest such assembly of the period with more than one thousand registered participants (Stein 1906a).

The psychiatrist Gyula Donáth, a member of the masonic lodge, was probably the most active spokesperson of the movement among psychiatrists. In his memoir, Donáth ${ }^{8}$ relates the activities of the Hungarian Good Templars according to which they convened high-ranking army officers and emphasized the importance of soldiers' abstinence in these meetings long before

${ }^{6}$ From the rich literature on the subject, see for instance, Székely (1889); Csillag (1895a, 1895b, 1899); Kende (1899); Grósz (1899); Stein (1901); Ferenczi (1999, 161-63), also in Jövendő 10 (1903): 56-57; Feldmann (1903); Madzsar (1905); Stein (1905, 1906b); Dóczi (1906, 1907, 1908).

7 See Hollós (1906, 115); Ferenczi (1999, 162-63); and Donáth (1940, 34-38).

${ }^{8}$ Donáth was the founding editor-in-chief and publisher of Klinikai Füzetek [Clinical Papers] starting in 1891. He was born in 1849, studied at the Viennese Medical Faculty under several distingished professors: the Hungarian born anatomist Hyrtl, the Berlin-born Jewish physiologist Brücke, and the internists Skoda and Oppolzer. In 1874, Donáth became the head of the laboratory at the Chemistry Department of the University of Graz. In 1877, he became docent in physico-chemistry. He returned to Hungary and practiced in Baja between 1879 and 1882. In 1882, he studied with Carl Westphal at his nervous and mental clinic in Berlin for a year. Then he worked at Helmholtz's physics and Virchow's gross anatomy laboratories. Subsequently, he also spent six weeks at Charcot's clinic in Paris. After returning home, he worked at a clinic for poor nervous patients in Pest, from which he resigned in 1893 to set up a nerve-clinic at Saint Roch Hospital (where the first Röntgen laboratory in the country was established under his direction). He became a private doctor of neurology in the Budapest Medical Faculty in 1893 and the head of the nerve-clinic of Saint Stephen Hospital in 1902. He studied epilepsy and used a salt-solution ("nátrium nucleinicum") to produce fevers, which by 1909 had been somewhat successful in treating paralysis progressiva. See Donáth 1940, 3-34. 
World War I (Donáth 1940, 35). They organized anti-alcohol campaigns in factories combined with milk-propaganda, and published pamphlets entitled "Tej és alkohol" (Milk and alcohol). In Donáth's optimistic account, these had good results: "factory workers are drinking milk instead of beer" during their breaks at work (Donáth 1940: 36-38). Members of the masonic lodge approached sport associations and published their findings related to a healthy lifestyle. To raise the "intellectual level" of the public, the Good Templars organized concerts and free lectures on scientific and artistic topics, all of which began with "appropriate and colourful anti-alcohol propaganda" to fight this "curse of humanity." After World War I, the government and Budapest city council withdrew their financial support from the Good Templars due to the post-war economic situation (Donáth 1940, 36-38).

In psychiatrists' accounts, the alcohol problem was also approached from the perspective of national economy. Lechner criticized countries where the state saw the monopoly of alcohol as an important source of income, and opposed alcoholism with the much higher costs associated with institutional networks (hospitals, prisons, and police) that aimed to reduce the social damage caused by alcohol (Lechner 1903, 119). Donáth scourged the "alcohol capital" and thought that state prohibition would be needed (Donáth 1940, 38). Lechner proposed the establishment of special asylums for alcoholics, and asked for the qualification of drunkenness as an "offense" and for the placement of alcoholics under custody.

Writings on alcoholism were permeated with degenerationist thinking and strongly connected to the lower classes. Oláh contended that, "among the lower classes, the day-labourers and coachmen, there are hundreds of thousands of alcoholics ... who morally slowly roughen, become animalistic in their souls, and procreate those anti-social offspring who form the ... youth of the society of the urban outskirts" (Oláh 1903, 53). The criminologist and clinical psychiatrist Ernő Moravcsik established firm links between crime, degeneration, alcoholism, and a number of other social problems:

[W]e have to differentiate between the miscreant proper, in other words, the habitual criminals, and those who are plunged into sin by accident and unfavorable conditions. The miscreants proper are mostly born, raised, and develop in an inferior atmosphere in which poverty, privation, financial problems, debauchery, loose moral and legal understanding, the bluntness or lack of obligation and sense of decency, antisocial inclinations, and a predisposition to commit forbidden crimes all 
produce a special character from generation to generation. Due to life's vicissitudes, these mostly degenerate, tainted individuals are more liable to the influence of alcohol, are more exposed to syphilitic infection and head injuries. (Moravcsik 1901, 102; cf. Moravcsik 1891)

Lechner claimed that alcohol was the source of 20 to 30 percent of all mental disorders, and was the chief cause of 70 to 80 percent of all crimes committed (Lechner 1903, 119). "The Goals and Purposes of the National Anti-Alcohol Association" referred to statistics from prisons, asylums, and hospitals when stated that "alcohol is the cause of illnesses and crimes in 50-60\% of cases in these institutions" (“Az Országos Alkoholellenes” 1909, i). Oláh also quoted statistics when he argued that "more than $50 \%$ of asocial and anti-social individuals descend from alcoholic parents" (Oláh 1903, 52). The solution to the alcohol problem, as envisaged by psychiatric experts writing on the topic or active in the temperance movement was complete abstinence (Oláh 1903, 53; "Az Orsz. Alkoholellenes..." 1909, i).

\section{Darwinism, Lamarckism, and Elements of Eugenic Thinking}

It is undoubted that the tackling of the discussed social problems by medical/ psychiatric professionals involved contemporary biological thinking and an organicist approach to the social body. Informed by Darwinism and degenerationist and eugenic thinking, at the 1902 Second National Congress of Psychiatrists Lechner claimed that degeneration and certain pathological dispositions were "the tools" of natural selection and that nature's aim to "muster out the weak and unfit" served the interest of the majority in the end (Lechner 1903, 117).

In the argumentation of many, a Lamarckian allowance for the influence of environmental factors on inheritance is also observable in addition to Darwinism. Among the latent factors that predispose the "race" (human race) to mental illnesses, for instance, Oláh, enumerates:

Over-reproduction, atavism, breeding disorder/disturbance [fajtenyésztési zavarok], marriages characterized by repugnance repeated over several generations, years of starvation following bad harvest, all may be distant causes of mental illnesses. More immediate causes include all those circumstances that formed factors damaging the ancestors' health: 
insufficient diet, overstressed work, chronic diseases, chronic poisoning, ... most of all, chronic alcoholic poisoning, furthermore, the bodily infection of ancestors, their mental life, protracted sadness, futile life struggle, great disappointments and passions, etc. (Oláh 1903, 50)

Elements of contemporary eugenic thinking and discourses are also present in several psychiatric texts. Oláh, for instance, identifies a close and undeniable relation between mental illnesses and the damaging influence of alcohol, syphilis, and "breeding mistakes of the 'genus homo sapiens"' in which cases "state intervention would result in positive achievements with predictable costs, investments, and interests" (Oláh 1903, 51).

While Oláh $(1903,58)$ believed that "the already stunted, ... weak products of a mistaken breeding system can still be improved," he added pessimistically that if "both wedded parties mutually cumulate the factors of insanity [terheltség] on their own sides," they may give rise to "increasingly degenerate offspring who, with their predispositions and feelings, will occupy a place outside of society, will be asocial, and even turn against society: anti-social." Concerning syphilitic paralysis progressiva, since it was understood to be inherited by the child at birth, and since experts regarded the disease as nontransferrable to the offspring only after three years of recovery for adults, Oláh $(1903,57)$ would have found it reasonable to rely on medical expert opinion and make marriage between infected people dependent on the lapse of time after treatment.

Oláh (1903, 59, also 65), however, warned that the biological laws of mental and physical development of the human race were still uncertain and, in regard to the improvement of the human race, different powers and needs prevailed than those in animal breeding: "It is still too early to wish to correct nature."

What he found possible was an attempt to avoid the "gravest breeding mistakes" with the help of a medical evaluation of the health records of those who wished to marry, to make the marriage of incurable imbeciles, epileptics, "anthropologically degenerate people"-especially when both parties are afflicted- "more difficult," while the marriage between young and healthy individuals would be "more easy" to attain. "Going further than this would not be possible without bringing the repugnant aspects of artificial breeding into the bonds of marriage." Even in marriage, Oláh $(1903,59,65)$ contended, nature can have her redeeming influence through attraction and choice, and through the positive influence a healthy party may have on the spouse. Finally, he 
mentioned as a "curiosity" Bleuler's idea of minor surgical intervention in "epileptics, idiots, and alcoholics" to stop the reproduction of degeneration, and the fact that in the United States there were already serious considerations given to the introduction of castration in such cases (Oláh 1903, 62).

Lechner $(1903,117)$ was also cautious and somewhat optimistic about the degenerative effects of society: "But nature set regeneration against degeneration. With the mixing of blood ... the (strengthening) of new abilities and their transmittal, the decaying genus may flourish again". The key to regeneration, according to him and most of his psychiatrist colleagues, was prophylaxis as defined by the expert psychiatrist. In order to fight degeneration, Lechner suggested a "hygiene of reproduction": "the expedient manipulation of marriage, upbringing, and social life." Rather than siding with the prohibition of reproduction in cases of people whose offspring endangers the health of society, Lechner $(1903,117)$ claimed that the doctor's duty was to implement the "hygiene of reproduction" via "educating the public," "spreading repugnance against damaging marriages," and enlightening people about "imprudent connubiality" via the "increased influence of family doctors experienced in psychiatry." It is the psychiatrically informed doctor's job to prevent "love's embrace" from becoming the undesired channel for the transmission of "pathological irritation, violent emotions, or alcohol-induced excitements."

While elements of eugenic thinking therefore can be found in Hungarian psychiatric discourses of the time, and psychiatrists were active in eugenicsrelated movements, such as the temperance movement, there was no formal eugenics movement designated as such before the beginning of World War I. Furthermore, psychiatrists used the concepts of "race" and "race breeding" in the sense of "human race" and not in any racialist and ethno-centric meaning.

\section{Conclusions}

By the end of the nineteenth century, psychiatrists increasingly claimed expertise in solving social problems that were related to psychiatric disorders such as nervousness, paralysis progressiva, alcoholism, crime, and poverty. In their arguments they utilized statistics, referred to the state budget, agricultural production, etc. (see Pándy s.d.) and generated strong social criticism. They also became involved in social movements, like the temperance movement, and published widely on these topics in scholarly as well as more 
popular journals. The underlying psychiatric explanation was degeneration, which the psychiatrist set out to fight by prophylaxis and the elaboration and implementation of the hygiene of mental and general health. This extension of psychiatric expertise to social arenas and everyday life certainly demonstrates that the psychiatric profession, which was mostly concerned with setting up the first mental institutions fifty years earlier, had strengthened by the turn of the century and expanded its manifold roles and functions in society.

This project was funded by the EU's FP7 (grant no PIEF-GA-2009-255614).

\section{REFERENCES}

"Az Országos Alkoholellenes Egyesület céljai és törekvései" [The goals and purposes of the National Anti-Alcohol Association]. 1909. In István Hollós, Alkohol és agymüködés [Alcohol and cerebration], inner cover-page. Budapest: Alkoholellenes Könyvek Könyvtára.

Benedek, László. 1913. "A paralysis progressiva aetiologiájáról" [On the aetiology of paralysis progressiva]. In Közlés a Kolozsvári F. J. Tudomány Egyetem Elme- és Ideggyógyászati Klinikájáról 38, no. 2: 233-43.

Bynum, William F. 1984. "Alcoholism and Degeneration in $19^{\text {th }}$ Century European Medicine and Psychiatry." British Journal of Addiction 79, no. 1: 59-70.

Chamberlin, J. Edward, and Sander L. Gilman, eds. 1985. Degeneration: The Dark Side of Progress. New York: Columbia University Press.

Csillag, Gyula. 1895a. "Az iszákosság elleni küzdelem" [Fight against alcoholism]. Egészség 9: 211.

_ 1895b. "Az iszákosság elhárítása" [The prevention of alcoholism]. Természettudományi Közlöny 27, no. 305: 378.

— 1899. A gyermekek alkoholizmusa elleni védekezés törvényhozási és társadalmi szempontból [The prevention of children's alcoholism from a legal and social perspective]. Budapest: Pesti Llyoyd-társ.

Dóczi, Imre. 1906. "Az alkohol befolyása a faj életére és fejlődésére" [The influence of alcohol on the life and development of the race]. Az Alkoholizmus 2: 134.

—_ 1907. "Alkoholélvezet és élettartam" [Alcohol consumption and life expectancy]. Az Alkoholizmus 3: 1.

_ 1908. "Az alkohol befolyása a faj életére és fejlödésére" [The influence of alcohol on the life and development of the race]. Közegészségügy 1: 112.

Donáth, Gyula. 1894. "A modern kultur-államok lakosságának testi elsatnyulása, különös tekintettel Ausztria-Magyarországra" [The physical degeneration of the population in modern civilized states, especially in Austria-Hungary]. Klinikai Füzetek 4, no. 10: 215-34.

. 1895. "A neurasthéniának elkülönítése a hysteria és a dementia paralyticától" [The distinction of neurasthenia from hysteria and dementia paralytica]. Klinikai Füzetek 5, no. 5: 105-15. 
1940. Donáth Gyula élete és munkája. Önéletrajz [The life of Gyula Donáth: An autobiography]. Budapest: Horizont Könyvkiadó.

Epstein, László. 1903. “A gyakorló orvos feladata az elmegyógyászat terén” [The duties of practicing doctors in the field of psychiatry]. Gyógyászat 47, no. 43: 67680 .

_ 1908a. "Az alkoholizmus társadalmi szempontból” [Alcoholism from a social perspective]. Az Alkoholizmus 4: 53.

— 1908b. “Az öröklésről” [On inheritance]. Természettudományi Közlöny 40: 405.

Feldmann, Bódog. 1903. "A szeszes italok és az iszákosság elleni küzdelem” [Spirits and the fight against alcoholism]. Természettudományi Közlöny 35: 116.

Ferenczi, Sándor. (1903) 1999. “A szesz” [Alcohol]. In A pszichoanalizis felé: Fiatalkori írások 1897-1908 [Towards psychoanalysis: Early writings, 1897-1908], edited by Judit Mészáros, 161-63. Budapest: Osiris.

Fischer, Jakab. 1892. “A neurasthenia [idegrenyheség].” Klinikai Füzetek 13: 395-419.

Grósz, Gyula. 1899. “A gyermekek alkoholismusáról” [On children’s alcoholism]. Klinikai Füzetek 9, no. 12: 31-42.

Hollós, István. 1903. Adatok a paralysis progressivához Magyarországon [Data on paralysis progressiva in Hungary]. Budapest.

— 1906. "Good Templars páholy az elmegyógyítóintézetekben” [Good Templars Lodge in mental institutions]. Az Alkoholizmus 2: 115.

— 1909. Alkohol és agymüködés [Alcohol and cerebration]. Budapest: Alkoholellenes Könyvek Könyvtára.

Kende, Mór. 1898. "A tabes aetiológiája” [The aetiology of tabes]. Klinikai Füzetek 8, no. 12: 3.

— 1899. "Az alkoholismus, különös tekintettel a gyermek idegrendszerére" [Alcoholism, with special attention to the child's nervous system]. Klinikai Füzetek 9, no. 12: 1-27.

Lafferton, Emese. 2006. "What the Files Reveal: The Social Make-Up of Public Mental Asylums in Hungary, 1860s-1910s. In "Moderne" Anstaltspsychiatrie im 19. und 20. Jahrhundert. Legitimation und Kritik, edited by Heiner Fangerau and Karen Nolte, 83-102. Stuttgart: Franz Steiner Verlag.

Laufenauer, Károly. 1899. “Neurasthenia." In A belgyógyászat kézikönyve [Handbook of internal medicine], vol. 6, edited by Árpád Bókay, Károly Kétli, and Frigyes Korányi, 1075-1113. Budapest: MOKT.

Lechner, Károly. 1903. "Az elmebetegkezelés újabb elvei” [The novel principles of the treatment of a mental patient]. In Második Országos Elmeorvosi Értekezlet Munkálatai [Works of the Second National Congress of Psychiatrists], edited by László Epstein, 106-21. Budapest: Pallas.

Lunbeck, Elisabeth. 1994. The Psychiatric Persuasion: Knowledge, Gender, and Power in Modern America. Princeton, NJ: Princeton University Press.

Madzsar, József. 1905. "A szeszes italok hatása az utódokra" [The influence of spirits on the offspring]. Az Alkoholizmus 1: 33.

Moravcsik, Ernő. 1891. "A degeneratív tünetek jelentősége a bünösségi hajlamnál” [The importance of degenerative signs in criminal dispositions]. Orvosi Hetilap 35, no. 2: 13-17. 
. 1901. "A büntettes elmebetegek elhelyezése és ápolása" [The placement and care of criminal mental patients]. In Első Országos Elmeorvosi Értekezlet Munkálatai [The works of the First National Congress of Psychiatrists], edited by László Epstein. Budapest: Pallas.

Nye, Robert. 1984. Crime, Madness, and Politics in Modern France: The Medical Concept of National Decline. Princeton, NJ: Princeton University Press.

Oláh, Gusztáv. 1903. Az elmebetegségek orvoslása [The cure for mental illnesses]. Budapest: Pfeifer Ferdinand.

Pándy, Kálmán. n. d. Népbünök és a szeszivás [National sins and alcohol consumption]. Self published.

Pick, Daniel. 1989. Faces of Degeneration: A European Disorder, c. 1848-c. 1918. Cambridge: Cambridge University Press.

Salgó, Jakab. 1896. "A szellemi munka hygieniája" [The hygiene of mental work]. Egészség 10: 211.

_ 1903. "Az elmebetegségek prophylaxisa" [The prophylaxis of mental disorders]. Budapesti Orvosi Újság 1: 487.

— 1905. A szellemi élet hygienája [The hygiene of mental life]. Budapest: Franklin Társulat.

— 1910. “Az ideg- és elmebántalmak társadalmi okai” [The social causes of nervous and mental disorders]. Budapesti Orvosi Újság 8, no. 5: 17.

Sarbó, Artúr. 1894. "A heveny idegkimerülésröl” [On acute nervous exhaustion]. Gyógyászat 34, no. 2: 13-14.

Schaffer, Károly. 1896. "Az agykimerülésről (cerebrasthenia) és ennek a terjedő hűdéses elmezavarhoz való viszonyáról” [On brain-exhaustion or cerebrasthenia and its relationship to paralysis progressiva]. Klinikai Füzetek 6, no. 9: 1-26.

Schwartzer, Ferenc. 1858. A lelki betegségek általános kór-és gyógytana, törvényszéki lélektannal [General pathology and treatment of psychic disorders, with forensic psychology]. Budapest.

Stein, Fülöp. 1901. "Az alkoholizmus elleni védekezésről” [On the prevention of alcoholism]. Természettudományi Közlöny 33: 636.

_ 1905. "Alkohol és munkaképesség" [Alcohol and labor capacity]. Az Alkoholizmus 1: 53.

- 1906a. Jelentés a X. Nemzetközi Alkoholizmus Elleni Kongresszusról [Report on the $10^{\text {th }}$ International Anti-Alcoholism Congress]. Budapest.

_ 1906b. "Az alkoholkérdés Magyarországon" [The alcohol issue in Hungary]. Orvosi Hetilap 50: 70.

Székely, Antal. 1889. "Az alkohol hatása az utódokra" [The influence of alcohol on the offsprings]. Természettudományi Közlöny 21: 395.

Takács, Endre. 1895. "A neruastheniáról” [On neurasthenia]. Klinikai Füzetek 5, no. $1: 3-33$. 


\title{
Who Is Mentally Ill? Psychiatry and the Individual in Interwar Germany
}

\author{
Zsuzsanna Agora and Virág Rab
}

Sixteen nations were involved in World War I with over sixty-five million soldiers in active service. Nearly nine million of them lost their lives, twenty-one million were injured, almost eight million disappeared or fell into captivity, and approximately one million suffered long-term psychological damage.

This chapter deals with the psychological consequences of World War I from two perspectives. First, it explores German psychiatry's approach at the time, which denied the vulnerability of the human psyche. Second, it examines the war's psychological consequences from the standpoint of the Hungarian politician Loránt Hegedüs, who was a psychiatric patient at an elegant Berlin sanatorium between 1921 and 1924.

The writings of Hegedüs, who had first-hand experience of what the Great War-or in his words the "great murderer" (1926, 118-19)—had done to the human psyche, are interesting not only because they provide us with a realistic picture of everyday life in a mental hospital in the 1920s, but also because they highlight the fact that the psychic consequences of war went far beyond frontline fighters and affected a much larger circle of society than previously thought.

The question the title of this chapter asks, "Who is mentally ill?," was closely related to the issue of normality, and as such it not only posed a challenge for German psychiatrists, but may have been part of a much wider discourse. According to eugenics, the soldier who could not overcome his fright was a degenerate. Hegedüs, however, regarded the war itself as a great evil that 
had made people ill. Similar arguments were shared by several psychoanalysts, especially Sándor Ferenczi $(1919,10)$, who called the war a "mass-experiment" that led to severe forms of neuroses. Following this link of thinking in particular, we examine in this chapter the consequences of the war on soldiers and civilians.

Every war has inevitable impacts: dead and injured, invalids and orphans. Numerous studies (EMRO 2002; WHO 2003) have documented that conflict, especially war, causes more death and disability than any disease. The impact of war also includes long-term physical and psychological harm to soldiers and civilians. However, fallen soldiers are only the tip of the iceberg. Consequences other than death are not well documented. Here, the accounts of a contemporary witness are particularly valuable.

Loránt Hegedüs (1872-1943) was a member of the Hungarian political, economic, and intellectual elite. He studied law in Budapest and sociology in London under Herbert Spencer, one of the leading sociologists of the time. After finishing his studies abroad, Hegedüs became an MP for the town of Pápa in 1898, then the Director of the Confederation of Hungarian Industrialists in 1905 and later its Vice President in 1912, and was also the President of the Hungarian Commercial Bank of Pest starting in 1913. For two decades he was the editor of the Economic Review. In the Teleki and Bethlen governments, he was Minister of Finance (1920-1921). In the autumn of 1919, he played a leading role in the organization of the Savings Bank and Bank Association and became its president in 1925. As a chief contributor to Pesti Hírlap (Pest News), he worked as a publicist and also engaged in economic and literary activities, authoring over fifty books. He was also a Protestant theologian, although he was not ordained. His father, a member of the founding generation of modern Hungary, was a self-made man who married Jolán Jókay, the niece of the well-known writer Mór Jókai, and became a respected member of the Hungarian political, economic, and intellectual elite. While Sándor Hegedüs was a member of the founders' generation, his son Loránt was an heir to the founders' legacy (Lengyel 1989, 73). Beside his professional competencies, his personal network and his ability to adjust to new situations also played an important role in coping with challenges.

Important personal documents about Hegedüs were recently found intact in the cellar of a villa in Buda. Zsuzsanna Zsindely (now Lazáry), Loránt Hegedüs's granddaughter, also provided us some highly informative memoirs from Sándor Zsindely, a recently-deceased grandson of Hegedüs, as well as a family chronicle. In our research, this rich and encompassing source 
material was also supplemented by a significant amount of both published and unpublished documents related to Hegedüs's work and his public, scientific, and literary activities. As these documents show, he spent three years in a sanatorium near Berlin in Schlachtensee. He also wrote about his illness in his published books, which can be considered pieces of introspective prose. Our most important sources were the Book of Tears (Hegedüs 1929), and the Way of Immortals (Hegedüs 1926). Through these works, readers have a firsthand look at the experience of patients in a Berlin sanatorium of the 1920s.

Hegedüs's illness was described as an "emotional disorder" in that period, as switches between spiritual exaltation and spiritual depression. The former is a disorderly elevated mood in which the patient shows extreme delight for a period of time, often connected to a pathological thought which is incomprehensible to a reasonable observer. The latter is a depression characterized by sadness, hyperirritability, distrust, and especially anxious obsessional ideation. It seems that Hegedüs's mood was euphoric and elevated more often than it was depressed.

His most severe mental problems developed when he faced failures as the Minister of Finance. His daughter Mária Hegedüs’s memoirs (1977) reveal that he was ill for over three years, from October 1921 to December 1924. He underwent treatment in Berlin-Schlachtensee in Germany and in Lassnitzhöhe in Austria. We cannot identify when exactly he was treated in Austria, as there are no relevant sources. He may have gone to the German sanatorium in September 1921 as he was already there when ex-King Charles IV attempted a Legitimist coup in the middle of October 1921. When he learned about the King's action, he attempted suicide. He provided a detailed account of it in his writings.

His therapist was the well-known German psychiatrist Siegfried Kalischer. It is also known from Mária’s memoirs that his daughter Margit (Mária's elder sister) visited her father in the sanatorium during Christmas in 1922, and he was already home by the Christmas of 1924 (Hegedüs 1977, 3-4).

On February 21, 1924, the Pesti Hírlap reported that "Loránt Hegedüs, former Minister of Finance, has made great progress in his state of health as we have been informed. The attending physician of the sanatorium notified the family about the good news and expressed his hope for a full recovery."

His daughter Margit brought him home to Budapest from Germany, accompanied by a nurse named Margarete (Hegedüs 1977). On Christmas 1924, Mária and Margit gave him a bottle of liqueur, the first time they saw him laugh since his illness began. He was soon visited by his friends as well, first 
by Mari Jászai, one of Hungary's greatest tragic actresses, and then by Lajos Zilahy, the Hungarian novelist and playwright. Hegedüs began to write articles for Pesti Hirlap, and his health improved rapidly. On January 22, 1925, Pesti Hirlap reported that he took his first walk outside. The following day, the paper reported on the funeral of the industrialist Ferenc Chorin, Sr:: "We should note here how moving it was when one of the deceased's best friends, former Minister of Finance Loránt Hegedüs, who is still recovering from his illness, appeared at the funeral parlor." The next Sunday, January 25, 1925, the paper published an article entitled "A Visit with Loránt Hegedüs." It quoted him as saying: "I feel nervous walking into the library. What is awaiting me, what great sorrow? I have always regarded the former Minister of Finance of Hungary as the Hungarian genius of our time. Who will I meet again on the sick-bed in the neighboring room after these four years? . . . The body is still fallible and weak but the spirit is already flying high and desires to create. It will definitely create."

Hegedüs purchased a half-finished "red house" on Gellért Hill in Buda after he fully recovered. His first article, entitled "The Enchanted Country," was published in Pesti Hirlap on Sunday, February 22, 1925, and he also started to deliver public science lectures in March 1925.

We are fortunate that Hegedüs wrote about his experiences in the sanatorium, describing the relationship between therapists and patients, nurses and patients, and among the patients themselves.

\section{The Impact of War on the Human Psyche in World War I}

\section{THE IMPACT OF WAR ON SOLDIERS}

During the Great War, the mass killing and mass suffering were a completely new experience both for soldiers and psychiatrists. Right after the war broke out, numerous soldiers suffered from somatic symptoms. Some were blinded or died, some hunched over, trembled, went mute, or had a mental collapse. As the number of those suffering from war-related illnesses increased, there were more and more medical debates on these mental symptoms, which were covered in the special journal Wiener Medizinische Wochenzeitschrift (1916, 944). In 1917, Robert Gaupp, a renowned German professor of psychiatry, reported on the phenomenon as follows: "The big artillery battles of December $1914 \ldots$ filled our hospitals with a large number of unscathed soldiers and 
officers with mental disturbances. From then on, that number grew at a constantly increasing rate" (Ulrich and Ziemann 1994, 102-103).

The wide diversity of terms used to define this phenomenon reflects the disagreement within the scientific community during and after World War I. English terms like soldier's heart, shell shock, war neurosis; German terms such as Granatschock, Psychopathie, Psychose, Neurose, traumatische Neurose, Neurasthenie, Angstzustände, and the French term traumatique de guerre are not simply alternative translations of uniform medical terms in different European languages; they reveal different understandings of the origins of mental illness due to war. As the historian of medicine Hans-Georg Hofer points out (Hofer 2012, 209-210), the phenomenon of "Kriegshysterie" opened up a wide discourse on trauma involving many different medical-psychiatric concepts, and these explanation systems provide valuable information on the cultural-historical contexts of the interwar period.

Contrary to the highest promoted ideal pro patria mori, fear was stronger than the fighting spirit. Fear of death, fear of being wounded, fear of day or night, fear of attack, or fear of waiting in the trenches (Fassin and Rechtman 2009, 40-41). "For tens of millions of men, death became visible (it was everywhere), they could smell it (it stank), they could hear it-and this was completely unexpected. ... The soldier in the Great War was no more prepared than any other man of the early twentieth century to confront such horror" (Rousseau 1999, 203). As Robert Gaupp, the well-known German psychiatrist and neurologist reported in 1914, psychiatric patients made up by far the largest category in the German and Austro-Hungarian armed forces: "the main causes are the fright and anxiety brought about by the explosion of enemy shells and mines, and seeing maimed or dead comrades.... The resulting symptoms are states of sudden muteness, deafness, ... general tremor, inability to stand or walk, episodes of loss of consciousness, and convulsions" (Ulrich and Ziemann 1994, 102-103).

The sheer number of traumatic casualties challenged army doctors everywhere in Europe. Since psychiatric knowledge was based fundamentally on the theories from the fin de sieclé, the discourse on soldiers' fear actually shaped the discourse on trauma as well. John E. Erichsen, a Danish surgeon, was the first person to describe the clinical symptoms manifested by survivors of railroad accidents. The term "trauma neurosis" did not appear in clinical accounts at that time, and mental disturbances following railroad accidents were not linked to any psychological etiology. The cause was thought to be an attack on the nervous system, and was further attributed to microlesions on 
the spinal cord resulting from railroad accidents (Fassin and Rechtman 2009, 31). Hermann Oppenheim studied the "railway spine" syndrome again, and his new term "trauma neurosis" was an important contribution to the discourse of trauma (Crocq and Crocq 2000, 47-55). According to him, nervous symptoms indicated a well-defined illness. It was caused by invisible microscopic changes in the brain triggered by a shocking accident (Oppenheim 1889, 123-27).

Oppenheim's organic theory increasingly fell out of favor during the war (Köhne 2009, 19), and discourse on trauma neurosis resulted in the "hysterical turn." This interpretation was held by the majority of army doctors who were "convinced that war neurotics were either simply 'hysterics' or 'malingerers' who intentionally invented symptoms in order to escape frontline service and gain some veterans' benefits or military pensions; or they suffered from some sort of hereditary, degenerative disease that caused their inability to cope with stress, and their lack of physical and psychological strength, will, bravery, patriotism, and self-sacrifice" (Erös 2014, 33-58). In the fall of 1916, the topic of the Psychiatric Conference in Munich was the origin of mental disturbances. There gathered well-known psychiatrists such as Robert Gaupp, Max Nonne, and Karl Boenhoeffer, who challenged Oppenheim's theory. According to them, soldiers with mental disturbances had a weak will and they malingered in order to receive a disability pension (Ferenczi 1919, 9-30).

Emil Kraepelin, one of the founders of modern scientific psychiatry, believed the primary origin of psychiatric diseases to be biological or genetic malfunctions, and this theory penetrated early modern psychiatry as well. $\mathrm{He}$ reported about his experience with war neuroses during World War I in his autobiography, published posthumously in Germany in 1983:

[As early as 1917], the question of war neuroses was raised. We mad-doctors all agreed that we should try to limit the excessive granting of compensation, which might lead to a sharp rise in the number of cases and claims ... the fact that all kinds of more or less severe psychiatric symptoms could lead to a lengthy stay in a hospital, or even to discharge from the military with a generous disability pension, had disastrous consequences. This was compounded by the population's feeling of pity for the seemingly severely ill "war-tremblers" [Kriegszitterer], who drew attention to themselves on street corners and used to be generously rewarded. In such circumstances, the number of those who believed that a "nervous shock" or, especially, having been buried alive entitled them to discharge and continuous support increased dramatically. (Kraepelin 1983, 189) 
This conference in 1916 was an extremely important event in the history of scientific psychiatry because it shaped psychiatric trends during and after World War I. After that meeting, it became the responsibility of German psychiatrists to detect fraudulent applications for war pensions. Mainstream psychiatrists firmly believed that those who died were heroic and normal, and those who survived were of inferior value, in other words "social parasites" and "miserable hypochondriacs" (Kraepelin 1919). When soldiers broke down, they left the fighting to healthier and stronger men who were more valuable to the national community.

In opposition to these trauma politics, representatives of the emerging field of psychoanalysis, particularly Sándor Ferenczi, Karl Abraham, and Ernst Simmel developed their own conception of hysteria, neurosis, and trauma, which seemed to be a humanizing alternative to the dominant German theory (Freud et al. 1919). Contrary to scientific psychiatric discourses, which did not question the political and military goals of the war itself, Loránt Hegedüs did criticize the war and its consequences in his autobiographical writings (1926, 1929).

\section{THE IMPACT OF WAR ON CIVILIANS}

Hegedüs observed those whose nervous system was damaged by the war:

If you take a train at Potsdamer Bahnhof, you can get to Berlin via two routes. Either on the main line or on the Berlin-Wannsee. The latter stops at the sanatoria located in wonderful forests and gardens one after the other. We, who were allowed to walk out and were considered depressed, melancholic, and curable by the doctors, stayed at places closer to the railway. Those whom the doctors thought would never be released were locked up farther back in the forest. $(1926,120)$

As Hegedüs claimed in his biographical writing, the war affected far more people than just the soldiers who died, were injured on the battlefield, or suffered from war neurosis. According to him, the war left its fingerprints on everyone's nervous system.

We all who are living during these days can see such a thing that mankind has never ever seen before! A terrible criminal has passed over us. Now the police can easily detect rogues on the basis of fingerprints, 
dactyloscopy. ... A horrible murderer walked among us, he was called World War, and the fingerprints of this murderer are there in our nervous systems. Not only were ten million people killed, not only did Europe destroy (waste, damage, destroy, or allow its own soul . . . to decay?) its own soul, that is, its middle class, ... but we have managed what nobody has ever managed to do, we have trampled down the future generation of Europe. (Hegedüs 1926, 118-19)

Although by 1914 nearly everyone believed that there would soon be a war, the news of its outbreak was cheered by the Spirit of 1914 (in German, Augusterlebnis). However, enthusiasm for the war soon faded away, and everyday life on the front not only disillusioned the soldiers, it often shocked them. What they lived through was actually the crisis of all crises, since a war is always the consequence of earlier crises causing a greater and more severe catastrophe.

It is also apparent from the writings of Hegedüs that, apart from the war, the social and economic processes of Europe also had a sickening effect on some of his contemporaries. Parts of his autobiography were written between 1921 and 1923 and thus with the aftermath of the war. Rapid enrichment, just like rapid impoverishment, could make one sick. In other words, social circumstances can lead to illness, as Durkheim suggested in his well-known work on suicide. The case of Hegedüs is one example of these phenomena, since his most severe psychiatric state occurred when he failed as a minister of finance, and failure at the service of the nation was considered a sign of (psychological) abnormality.

In his autobiographical writing, Hegedüs reported (1926) on examples of civilian casualties among his fellow patients. He described some cases where the human nervous system could not bear rapid enrichment. A woman who became rich very quickly felt ill, could not sleep, and gained so much weight she reached 330 pounds. Another case did not occur in the institute where Hegedüs was staying, but farther back in the forest from which nobody usually emerged: "It was a German porcelain merchant who acquired enormous wealth during the war. Then he believed he was the Prince of Wales. He took a bath every half an hour, etc., until a great turn occurred in 1923: hyperinflation. When the Mark deteriorated, he realized he was not the Prince of Wales. He began selling cups again" $(1926,123)$.

Hegedüs's experience was not independent from the changing political and economic circumstances of the war and postwar period. He had three 
traumas in his life. As he put it in his writings, he passed through three hells: the first when he was held in prison as a hostage in 1919 during the Hungarian Republic of Councils (Hungarian Soviet Republic or the Commune); the second while he was Minister of Finance, when the Treaty of Trianon (the partition of Hungary) turned his ministry "into a torture chamber for someone who wanted to save the middle class in Hungary" (Hegedüs 1926, 117-18); and the third his long illness. As already mentioned, he wrote about these traumas in his books $(1926,1929)$, and in the former, he interpreted the Bible from a neurological perspective. His main trauma was his unsuccessful economic plan in 1920, in which he attempted to consolidate the post-Trianon Hungarian economy. When he failed, he went into a selfimposed exile.

In his writings, he described the types of therapy he received. However, we have to distinguish treatments received during and after the war, and furthermore, treatments used on either soldiers or civilians or both, although these were in some cases very similar. Hegedüs reported on a case in which, for some weeks, his physician (Siegfried Kalischer) was replaced by a military physician who prescribed such a strong medicine for his fits of nerves that his nurse Margarete was concerned about his heart function $(1929,8)$. In fact, she refused to obey the doctor's orders; she locked up the strong medicine and later showed it to Kalischer, who said his patient would not be alive if he had taken it. Margarete saved Hegedüs's life once again. Incidentally, this case shows that military psychiatrists were at times officially assigned to civil psychiatric clinics. These intersections between military and civil psychiatry were important for military psychiatry because it also contributed to the general institutionalization of scientific psychiatry (Lengwiler and Ramsauer 2000).

Not every treatment was as dangerous as the one recounted above. As Hegedüs reported (1926), the lady who became rich too fast complained to the doctor that she was overweight and could not sleep. Then she got the following instructions:

Get up at 8 in the morning, hoe for an hour and weed for an hour, then work in the kitchen till noon, and walk for two hours without a gentleman in the afternoon. This was her treatment. In the evening she had to take some liquid sealed in a blue bottle (pure water) against insomnia. She sweated and underwent the treatment for four weeks. She recovered. . . (122-23) 
He reported on his own treatment in the following way:

I, as a journalist, had to undergo the most terrible treatment; nobody has ever undergone a similar course of treatment. In order to divert my attention, I had to read foreign newspapers all day. I read through everything from the Russian Piech to the daily paper of the spiritualists of Chicago; on Sundays, I added up the charity donations collected by the Berliner Tageblatt and I know the programs of twenty-two German parties by heart, which no German can boast, as not even the parties know their own programs. Nurse Margarete had to bring in each paper from the reading room decorated with Biedermeier curtains at a predetermined hour. (Hegedüs 1929, 13)

The common aim of all treatments using placebos, electrotherapy, or strong medicine was to establish order and bring patients back to the world of normality. The strict adherence to social norms could have provided a fortress in a disintegrating world and could have guaranteed the integrity and entirety of traditional communities and values. Nurse Margarete was an example of a successfully socialized member of an authoritarian order, the Kaiserreich:

She had a Prussian spirit. How is it [asked Hegedüs] that, having become disappointed in my race and in myself, I went to pieces while Margarete, the Prussian nurse sitting next to me; whose country also lost the war; who is now left in poverty though she grew up in affluence; whose homeland has been destroyed; whose German glory has been trampled down; cannot give way to despair. For this, she has no talent. ... The point of crystallization in the Prussian spirit is undoubtedly the same unconditional fulfillment of duties (ingrained by Frederick the Great and Kant) towards Kaiser and country. The French king said "I am the state," while the Prussian feels, "I am the state's." (Hegedüs 1929, 12)

Hegedüs described her with masculine features. She was not afraid, she ran in a hail of gunfire, she was virtuous because she did not accept her salary, she strenuously performed her duties, and most of all, she had no fear. As Hegedüs wrote $(1929,12)$, Margarete's task was nothing else but to lead him back to normality.

War psychiatry was intended to offer efficient solutions to the challenges posed by "weaker" soldiers. Military psychiatrists were convinced that author- 
itarian methods combined with electrotherapy would "transform weaklings into true fighters with a hunger for victory" (Fassin and Rechtman 2009, 50). In other words, they had the promise of making a man who was different into a man who was normal. The ability to extract a confession from weaklings was crucial in these treatments. They convinced their patients to give up their "trivial, individualist motives, which were incompatible with the moral values underpinning patriotism." Military psychiatry served the state and its goals to the fullest possible extent, and its concept of normality cannot be separated from the major political discourses of the time.

\section{Emerging Psychiatry in the Modern Period}

The modern period was burdened with crises and rapid progress. Since the end of the nineteenth century, reactions to economic and political modernization were a frequent topic in the discourse of the educated German middleclass (Bildungsbürgertum). The core of the discussion was the collapse of traditional structures (Rinn 2005, 347), the isolation of the individual, and simply the fear of modernization. Psychiatry and neurology reacted to the fear of losing the harmony and unity of the human psyche in the age of modernity. In Wilhelm Wundt's laboratory, man seemed to have been reduced to only his functions, since he tried to provide objective measurements of conscious processes by using reaction time techniques.

The critics of natural science, like Felix Krueger (founder of the Leipziger School), his colleague Eduard Spranger (founder of the Marburg School), Erich Rudolf Jaensch, and Max Wertheimer (founder of the Berlin School of gestalt psychology), fought for the human psyche and argued against psychology without a soul. They rejected (Rinn 2005, 354) the idea of using a model formulated exclusively by the natural sciences as a means to explain psychological phenomena in terms of cause and effect or as a mechanism of interchangeable parts. These psychiatrists argued, similar to Dilthey's approach, for understanding the human psyche as a unity of body and soul. In 1925, Eduard Spranger wrote about two psychological trends: the holistic approach and research on individualism. Although in the interwar period all three of the abovementioned schools flourished, the viewpoint of military psychiatry was fundamentally influenced by the methods and theory of Rudolf Jaensch.

Jaensch's method (1927) (eidetic imagery and typological methods of investigation) examined the human character in detail. He looked for indi- 
vidual differences and not for general psychological characteristics. His aim was to classify his subjects into different eidetic types aware of the uniqueness of their worldview (Jaensch 1928). Moreover, his effort to interpret the individual character of man as precisely as possible reveals the fight of modern psychiatry against the loss of the individual in the mass (Rinn 2005, 361). Yet, all these positive aims also provided grounds for social inclusion and exclusion and for military fitness (Ash and Hau 2000, 12-31). According to Jaensch, Spranger, and Krueger capitalism destroyed harmonious human existence; people became greedy and lost their communities. Hence, according to Jaensch $(1922,36)$, the main task of psychology was to be the leader of life and culture, and furthermore, to become the protector of the common good. This utopian aim was to help man return to his community. But the desired value of community became a norm, which was a must for any individual.

However, the paradigm of the primacy of the whole and the community is embedded in a much broader context. It embraces nearly all fields of life because it is a value orientation as well. According to the holistic interpretation, that which is whole is harmonious, singular, and healthy. In this approach, the dominance of the parts (for instance, democracy) is chaotic, modern, and pathological. According to a few psychologists, the main purpose of psychology was to lead, control discipline, to be the keeper of normality and common good (Rinn 2005). Jaensch, Krueger, and Spranger firmly believed that the crisis of the individual can only be solved if he returns to the community. These utopian aims easily found their way to Nazi ideology. Jaensch was the leader of the German Psychological Association until 1940.

\section{Normative Order and Violence}

The war ended in 1918 with the defeat of the German Empire and the AustroHungarian Monarchy, and the national and patriotic ideals that underpinned them also experienced crisis. Patriotism was the justification for using brutal therapeutic methods to treat "malingerers" and "weaklings," so military psychiatrists did not question these methods. However, while electrotherapy found its most widespread application in the Austrian and German armies, it was also in these places that military psychiatrists first questioned these methods (Fassin and Rechtman 2009, 51). In the trial of the Austrian psychiatrist Wagner von Jauregg, Freud challenged the aetiological hypothesis of his colleague, but this trial seems to have been unique in Europe. Although 
psychiatrists in Britain protested against the stigmatization of psychically wounded soldiers beginning in 1917, their view became widely accepted only after the war, and particularly in the United States (Fassin and Rechtman 2009). In France there has never been any official condemnation of inhuman psychiatric practices; French psychiatrists never questioned the brutality of their treatments.

The stigma of "weakling" and "malingerer" was not fully removed in interwar Germany. However, in many cases, the ministries of the Weimar Republic re-examined the medical opinion of psychiatrists concerning war pensions, but in the controversy over the 1918 defeat, Hitler and other völkisch groups, among them renowned German psychiatrists like Julius Roßbach, Emil Kraepelin, Robert Gaupp, and Eugen Kahn, used the term "weakling" to stigmatize war invalids, women, and left-wing politicians; these groups became scapegoats in the postwar German society (Kiss 2015, 62-74). Eugen Kahn delivered a lecture at the conference of German psychiatrists in Munich in 1919, entitled "Psychopathic Leaders of the Revolution," in which he analyzed the character of fifteen German contemporary revolutionaries. He identified the following categories: ethically defective, fanatic psychopath, hysterical, and manic depressive (Kahn 1919, 90-106). According to his analysis, all of them were weak, egoistic, unable to be objective, and anti-social. This description clearly shows continuity in the conceptualization of malingerers in German mainstream psychiatry. Concepts of normality inherited from the Wilhelmine era flourished persistently during the period of the Weimar Republic until the end of World War II.

The concept of the normality of violence changed only gradually and unevenly after World War II, since warfare had been (and in many circles still is) considered normal and a necessary evil. Furthermore, fighting and heroic soldiers had high social status before and after World War I. The idea of war as a scourge appeared only in the decade following the war, especially in France but not in Germany. The interwar period in Germany was burdened with crises and the desire for a strong, authoritative hand penetrated deeply into society. Violence was the tool of power and order in states. Private violence was evil (Schnell 2014); only state violence was considered rational. Thus, in the autobiographical work of Hegedüs $(1929,13)$, Margarete handled the situation in a rational, normal, and legitimate way when she broke the walking stick of a Polish patient. Many accepted violence in its broader sense during and after World War I, and it was legitimized by the state. In this order, psychiatry (in its role as the guardian of normality) was only a part of the whole, 
which Johan Galtung (1990) called structural violence. According to him, structures do not generate violence, but inhuman structures are violent because they reproduce inequality and prevent the development of individuals. The norms of psychiatry in the interwar period were actually military norms. They demonstrate that diminished empathy and remorse, sadistic tendencies, and firmly maintaining a belief in one's superiority over another were accepted as "normal" qualities. German interwar psychiatry sought to be the guardian of normality, but it was in fact the warden of abnormality.

\section{REFERENCES}

Ash, Mitchell G., and Michel Hau. 2000. "Der normale Körper, seelisch erblickt." In Gesichter der Weimarer Republik: Eine physiognomische Kulturgeschichte, edited by Claudia Schmölders and Sander L. Gilman, 12-31. Cologne: DuMont.

Crocq, Marc-Antoine, and Louis Crocq. 2000. "From Shell Shock and War Neurosis to Posttraumatic Stress Disorder: A History of Psychotraumatology." Dialogues in Clinical Neuroscience 2, no. 1: 47-55.

Erős, Ferenc. 2014. "Kínzás vagy gyógyítás: Pszichiátria és pszichoanalízis az első világháborúban" [Torture or therapy: Psychiatry and psychoanalysis in World War I]. Kaleidoscope 5, no. 8: 33-58.

Fassin, Didier, and Richard Rechtman. 2009. The Empire of Trauma: An Inquiry into the Condition of Victimhood. Princeton: Princeton University Press.

Ferenczi, Sándor. 1919. “Die Psychoanalyse der Kriegsneurosen." In Zur Psychoanalyse der Kriegsneurosen, edited by Sigmun Freud, Sándor Ferenczi, Karl Abraham, Ernst Simmel, and Ernest Jones, 9-30. Leipzig: Internationaler Psychoanalytischer Verlag.

Freud, Sigmund, Sándor Ferenczi, Karl Abraham, Ernst Simmel, and Ernest Jones. 1919. Zur Psychoanalyse der Kriegsneurosen. Leipzig: Internationaler Psychoanalytischer Verlag.

Galtung, Johan. 1990. "Cultural Violence." Journal of Peace Research 27, no. 3: 291-305. Hegedüs, Loránt. 1926. A halhatatlanok útja [The route of immortals]. Budapest: Singer \& Wolfner.

—_ 1929. Könnyek könyve [The book of tears]. Budapest: Singer \& Wolfner.

Hegedüs, Mária. 1977. "Verba volant, scripta manent." In Family Chronicle, edited by Sándor Zsindely. Budapest: Manuscript.

Hofer, Hans-Georg. 2012. "Gewalterfahrung. 'Trauma' und psychiatrisches Wissen im Umfeld des Ersten Weltkrieges." In Terror und Geschichte, edited by Helmut Konrad, Gerhard Botz, Stefan Karner, and Sigfried Mattl, 205-21. Vienna-Cologne-Weimar: Böhlau.

Jaensch, Erich Rudolf. 1922. "Über die subjektiven Anschauungsbilder." In Bericht über den VII. Kongreß der Gesellschaft für Experimentelle Psychologie 1921 in Marburg, edited by Karl Bühler, 3-49. Jena: Gustav Fischer. 
1927. Die Eidetik und die typologische Forschungsmethode: in ihrer Bedeutung für die Jugendpsychologie und Pädagogik, für die allgemeine Psychologie und die Psychophysiologie der menschlichen Persönlichkeit; mit besonderer Berücksichtigung der grundlegenden Fragen und der Untersuchungsmethodik. Leipzig: Quelle \& Meyer.

ـ 1928. "Über Methoden der psychologischen Typenforschung." Zeitschrift für Psychologie 108: 1-16.

Kahn, Eugen. 1919. "Psychopathen als Revolutionäre Führer." Zeitschrift für die gesamte Neurologie und Psychiatrie 52: 90-106.

Kiss, Zsuzsanna. 2015. "Hősök és bünbakok a Weimari Németországban” [Heroes and scapegoats in Weimar Republic]. In Bünbak minden időben: Bünbakok a magyar és az egyetemes történelemben [Scapegoat in all times: Scapegoats in Hungarian and universal history], edited by György Gyarmati, István Lengvári, Attila Pók, and József Vonyó, 62-74. Pécs-Budapest: Kronosz \& Magyar Történelmi Társulat-Állambiztonsági Szolgálatok Levéltára.

Köhne, Julia Barbara. 2009. Kriegshysteriker, strategische Bilder und mediale Techniken militärpsychiatrischen Wissens (1914-1920). Husum: Matthiesen Verlag.

Kraepelin, Emil. 1919. "Psychiatrische Randbemerkungen zur Zeitgeschichte.” Süddeutsche Monatshefte 17: 171-83.

1983. Lebenserinnerungen. Berlin: Springer.

Lengwiler, Martin, and Nadja Ramsauer. 2000. Zwischen Klinik und Kaserne. Zurich: Chronos.

Lengyel, György. 1989. Vállalkozók, bankárok, kereskedők: A magyar gazdasági elit a 19. században és a 20. század első felében [Entrepreneurs, bankers, and traders: The Hungarian economic elite in the 19th and early 20th centuries]. Budapest: Magvető.

Lerner, Paul. 2003. Hysterical Men: War, Psychiatry, and the Politics of Trauma in Germany, 1890-1930. Ithaca and London: Cornell University Press.

Oppenheim, Hermann. 1889. Die traumatischen Neurosen. Berlin: August Hirschwald.

Rinn, Gregor. 2005. "Der Kampf um das Subjekt.” In Politische Kulturgeschichte der Zwischenkriegszeit 1918-1939, edited by Wolfgang Hardtwig, 343-74. Göttingen: Vandenhoeck \& Ruprecht.

Rousseau, Frédéric. 1999. La Guerre censurée. Une histoire des combattants européens. Paris: Seuil.

Schnell, Felix. 2014. “Gewalt und Gewaltforschung.” Docupedia-Zeitgeschichte. http:// docupedia.de/zg/Gewalt_und_Gewaltforschung?oldid=106424.

Ulrich, Bernd, and Benjamin Ziemann. 1994. Frontalltag im Ersten Weltkrieg. Wahn und Wirklichkeit. Quellen und Dokumente. Frankfurt am Main: Fischer.

World Health Organization. 2003. Mental Health in Emergencies: Psychological and Social Aspects of Health of Populations Exposed to Extreme Stressors. Geneva: WHO.

World Health Organization Regional Office of the Eastern Mediterranean. 2002. Health under Difficult Circumstances. Cairo: EMRO. 



\title{
Russian Psychiatry beyond Foucault: Violence, Humanism, and Psychiatric Power in the Russian Empire at the End of the Nineteenth and in the Early Twentieth Century
}

\author{
Ruslan Mitrofanov
}

Many buildings of psychiatric hospitals are former barracks, prisons, or concentration camps. In 68 percent of the hospitals, the windows are barred. A third of all psychiatric hospitals in the country have been declared unserviceable due to emergency conditions since 2000.

Karatelnaja psihiatrija $v$ Rossii

The front porch of the hospital looks out over a beautiful and shady garden with walkways right in front of the hospital façade. ... The small number of torn clothes can serve as proof of the non-restraint system, which is practiced here on a large scale.

P. A. Archangelsky, Inspection Reports of Russian Psychiatric Institutions: The Kazan District Hospital, 1887

In February 2014, the European Court of Human Rights found the conditions of detention of a patient identified as N., held in the Kazan specialized psychiatric hospital under intensive supervision, to be inhuman and degrading. According to N., the wards were in a terrible state. In the "closet" where he was kept, there was nothing but a bed and a bucket for faeces. There was no

This study was supported by a grant of the Russian Science Foundation (Project No. 19-48-04110). 
ceiling fan. Next door there was a so-called toilet collector (Russian Planet 2013). Physical violence was applied to the patients. The mentally disabled were forcibly tied to beds by other patients, a practice that had been prohibited by the "Law on Psychiatric Care" in the Russian Federation since 1992. Victims could be tied to beds in the general wards for more than a day. The hospital lacked basic hygiene and had not provided patients with necessary daily walks.

The Kazan hospital was opened in 1869. It was the first professional psychiatric institution in the Russian Empire. Represented by psychiatric institutions in modern Russia, the history of the institutionalization of mental health care goes back to the nineteenth century. In his "histories of the present" (Porter 1998, 2), Foucault not only shows how modern disciplinary institutions, like the psychiatric hospital, inherited the overall arsenal of violent practices emanating from the discourse of "madness" prevalent in the eighteenth and nineteenth centuries but also, and perhaps for the first time, turns to the ethical aspects of this discourse: "Are you able to endure your own history? Here is the story and here is what turns out in the scheme of rationality underlying this story, in the type of its obviousness, in its postulates, and so on. Now it is your turn" (Foucault 1984). Following Focault, we can ask what do we know about pre-revolutionary Russian psychiatry? What was Russian psychiatric power like? It might be more productive to pose those questions in another way: what is the difference between punitive, isolative post-Soviet and pre-Soviet practices of psychiatry? How was psychiatry carried out and how did the Russian psychiatric community simultaneously question it at the end of nineteenth and in the early twentieth centuries? How can one analyze this story without falling either into "despair" or "hysterics" after pronouncing the three cherished Foucauldian terms: "archeology," "genealogy," and "problematization"?

This chapter is devoted to violence, humanism, and psychiatric power: key concepts in the development of psychiatry in nineteenth-century Russia. Usually scholars, including Foucault, consider "violence" and "psychiatric power" as an irrational, inhumane, cruel, and unquestionable set of conventional medical treatments implemented by mental science in that period. Thus, based on the ordinary, everyday coercive practices in the hospital of that time, contemporary researchers formed an analysis of its discourse to be insulating and disciplinary. This article proposes moving beyond this teleology. Using the example of Imperial Russian psychiatry, the phenomena of "violence" and "psychiatric power" emerge as categories of common practice 
and, at the same time, of thoughtful, critical analysis of these practices within the broad community of Russian psychiatrists. Such an approach avoids the "disciplinary" ambiguity of Foucault but also highlights the development of Russian imperial psychiatry as a self-critical and self-analytical system of doctors' beliefs that questioned the limits of their own psychiatric power. I will begin the chapter with a brief historiography. Then I will critically reflect on Foucault's approach within the empire-wide debate dedicated to the understandings of violence/humanism through the implementation of the so-called non-restraint regime and bed therapy in Russian psychiatric practice.

\section{Foucault and the History of Russian Psychiatry}

Foucault never explicitly stated that he was writing about the history of psychiatry in France particularly, but rather the pan-European history of disciplinary techniques mostly in "Western societies" of the so-called "ancien régime." In Psychiatric Power and other texts, one can find such generalizations as "for the psychiatrists of this period" (Foucault 2006, 28), "in the system of psychiatric treatment of this [nineteenth century] time" (Foucault 2006, 153), "confinement, that massive phenomenon, the signs of which are found all across eighteenth-century Europe ...." (Foucault 1965, 46), etc. Historians have questioned whether Foucault's model is applicable to prerevolutionary Russia. In many of Foucault's texts one can hardly find a direct reference to the pre-Soviet institutions of psychiatry strictly connected to the Western European "panopticon". In an interview with Jacques Rancière, Foucault directly stated that the Soviet "Gulag" is not the same phenomenon as coercive disciplinary technologies of European countries originating in the nineteenth century. He emphasized that it is necessary to distinguish between democratic and totalitarian political regimes (Kola 2001, 230-233). The primary debate in historiography then was connected with the question: how could the disciplinary institutions in Imperial Russia be defined through the prism of Foucault's "power-knowledge" approach?

One of the first crucial works that explored the legal situation of marginalized people in late Imperial Russia was The Keys to Happiness: Sex and the Search for Modernity in Fin-de-Siècle Russia by Laura Engelstein. She boldly asserted that the power elites in conjunction with the academic communities engaged in the formation of the disciplinary model of society in the Russian Empire were not as visible as, for example, in contemporary European 
states. For Engelstein, the project of "Russian modernity" as an interaction between the scientific community and the disciplinary legal state failed early and ended entirely with the establishment of the radically anti-liberal Soviet regime (Engelstein 1992, 8). Through her concept of modernity in late Imperial Russia, she not only questioned the explanatory model of Foucault in the Russian context (and, as a consequence, in Western Europe too), but once again provoked discussion about the possibility of a particular Russian path (Sonderweg), which was different from that of Western Europe (Koshar 1993; Mogilner 2016). Represented through the professionalization of scientific psychiatry, the cause of Russia's "combined underdevelopment" (using Engelstein's term) has been alternately seen in terms of a lack of western "medieval medical guilds and ... strong corporate institutions" (Solomon 1983, 7), or in terms of the absence of an independent and powerful corporate solidarity with Western European academic communities (Brown 1981, 4).

Taking Engelstein's idea of the Manichean role of industrialization and urbanization of everyday life, which damaged the population of the Empire, British historian Daniel Beer argues that "the fate of liberal modernity" did not die with Tsarist Russia; on the contrary, it was embodied in the revolutionary project of the Soviet regime. Using the common arsenal of progressive liberal ideas the Bolsheviks, as well as the modern scientific elite of the Russian Empire, founded it on the belief that "human material could and should be renovated" after the devastating effects of capitalism (Beer 2008, 207). Thus, Beer not only challenges Engelstein's concept of the discontinuity of the liberal project, but also reasserts a model of Foucault's disciplinary society to the Russian reality at the turn of the century, an application that ultimately denies Russia's Sonderweg.

Another group of Russian and foreign sociologists, political scientists, and philosophers published in well-known books and monographs such as Madness and the Mad in Russian Culture or Michel Foucault and Russia, on the contrary, have convincingly shown that the French philosopher's methods can be successfully applied to Russian history (Kharkhordin 2001; Iangoulova 2007; Dyakov and Vlasova 2008). In his excellent article "Problematization as a Mode of Reading History," sociologist Robert Castel encouraged historians to reflect on the possibility of using the "history of the present" and "problematization" through the implicit "requirements of historical methodology" (Castel 1994, 1). Similarly, O. V. Kharkhordin, through a detailed analysis of the commentary of Hubert Dreyfus and Paul Rabinow, reveals "a particular method of Foucault that is potentially applicable to the analysis of any other 
culture and which can therefore be used, for example, by Russian researchers" (Kharkhordin 2001, 46). Here one can ask a few Foucault-inspired questions: where is the research "ideology" hidden when completely heterogeneous and culturally conditioned practices are initially attributed to a "common" discourse shared by all cultures? Does this mean that one of the cultures has the latent power to impose its legitimacy on all the others? How is the dependence of different cultures' discursive practices determined (e.g., the "Western"/"non-Western"; "European"/“Russian," etc.)? Where do the borders lie in this case?

Thus, many approaches to the history of psychiatry formulated analytical questions under the influence of an idealized and essentialist "Western model." Such umbrella terms as "liberalism," "Western path," or even "Sonderweg" act in this case as "a-historical" or all-embracing analytical categories that "[raise] questions about its analytical usefulness and applicability" (Mogilner 2010, 665). Moreover, it is not clear how one particular concept (like a Russian Sonderweg) is coherently and consistently related to the others (like Foucault's "power-knowledge" conception). One could also argue that the historiography of the subject has generally not attempted to actually critically apply Foucault's approach to the sources of Russian history, but rather to understand how it might be applied. Another fundamental methodological uncertainty is also typical to this type of analysis. Whereas each author tries to conceptualize his own understanding of "Foucault's approach" as it is called in Russian scholarship, its continued development causes a real discrepancy between the strict analysis of a particular notion or concept of the French philosopher and its applicability to a general explanatory model of the author's text. Therefore, the problem of using Foucault's approach raises a complicated question for the researcher: whether to yield to Foucault's theoretical framework and search for universalistic "totalities" and "technologies of power discourse" in the specifics of Russian history, or start from the categories of practice and the analytical language of the subjects of history?

Despite a number of recently published studies, some of which are devoted to the transfer of ideas and discourses between Russian and European psychiatrists, psychologists, and anthropologists (Solomon 2006; Mogilner 2013; Savelli and Marks 2015), the significance of Foucault's approach in a qualitatively different comparative context has not yet been revised. New analytical language could be developed to describe the heterogeneous and transnational process of psychiatry's institutionalization in the Russian Empire. Andreas Renner, the German historian and specialist in the history 
of medicine, reasonably notes that specialists in the field still lack comparative studies in the history of medicine between Western and Eastern Europe (Renner 2011, 222).

\section{In Search of a New Analytical Language}

The new analytical language could be represented in the categories of selfanalysis and self-description in the imperial psychiatric discourse used by Russian clinicians. Current scholarship is largely based on the approach of "new imperial history" and is closely associated with a group of historians represented by the editors of $A b$ Imperio, such as M. Mogilner, I. Gerasimov, S. Glebov, A. Kaplunovski, and A. Semyonov (Gerasimov et al. 2005). As the editors note, the very epistemological problem is that testimonies of the past cannot be simply reduced to the logic of the present socio-cultural reality (Gerasimov et al. 2005, 15). Even if a clearly visible empire remains in the project of the Soviet Union, one cannot directly reveal the same "imperial ossature" in a newly fledged political form. In this sense, it is not only impossible to talk about the "genealogy" of the two projects because of the revolutionary rupture, but it is even challenging to discuss their "archeology" in Foucauldian terms: empires do not exist in the "contemporary social experience neither in a hidden sense, not in a 'snapshot' view" (Gerasimov et al. 2005, 15). In contrast to the "archaeological" and "genealogical" methods of Foucault, the authors put forward their own "paleontological" approach. Based on this approach, a researcher is not interested in a "transposition" of the present-day situation to a given historian past, but in reading the socalled "dead language" of the empire that requires a certain estrangement from contemporary language norms and practices (Gerasimov et al. 2005, 16). It means that the historian does not seek to depict the imperial case study in a "genuine light" or in terms of "how it actually occurred," but rather to better understand which particular features, ideas, and worldviews lay in this "dead" type of rationality. In such an approach, the researcher sheds light on the consciously chosen languages of a given historical actor's self-description in which the subject tries to describe, depict, or reflect on him/herself through his/her own self-sufficient analytical categories. Consequently, with respect to a given scope of analysis, the historian pays great attention to the most central and peripheral concepts and terms of psychiatric language that were widely used and conceived by the medical environment in the period they are 
studying. Some of these concepts, for instance "violence" and "humanism," were parts of Russian psychiatric discourse at that time.

According to Foucault, psychiatry in the nineteenth century was not formed strictly as scientific or medical knowledge, which treats the patient through the classification of diagnoses, such as somatic medicine, but as an institution of daily violence that included elaborate regulations of isolation, exclusion, and eventually the "great confinement." The coercive origins of psychiatry were undoubtedly legitimized as "scientific" features in contrast to the rationally arranged, diagnostic knowledge represented at the same time, for example, by therapy, surgery, fundamental human biology, etc. (Foucault 2006, 25, 28-29, 106). Foucault's assertion is echoed by Robert Castel: "in the approach to the phenomenon of modern psychiatry, madness hides a failure of the scientific rationality and humanistic justifications on which it is based, appealing to the concepts of treatment and recovery. In the sixties, in the era of glorification of the social and scientific progress and implementing democracy, psychiatry sharply contrasts with this social background" (Castel 2001, 36). The doctors applied violent measures of restraint of the mentally ill because the institute's functional logic was based on violence. Thus, through the categories of ordinary, everyday coercive practices in the hospitals of that time, researchers formed its discourse as insulating, disciplinary, punitive, etc.

In fiery discussions among the Russian psychiatrists from all over the empire over the implementation of non-restraint or bed rest, the phenomenons of "violence" and "humanism" were simultaneously considered categories of regular daily practice and categories of reflective, self-critical analysis of these practices. They not only called into question the "humanity" of therapeutic standards, many of which had been borrowed from abroad, but constantly questioned the boundaries of their own psychiatric power. What are the origins of violence in a mental hospital? How can it be reduced? Where should the limits of its use in psychiatric practice lie? To what extent are foreign ideas and restricting medical regimens applicable to the heterogeneous Russian social environment?

In opposition to Foucault, I propose considering the phenomenon of violence and humanism as a single whole, as analytical categories closely related to each other. In general, "humanism" was understood as the degree to which doctors and the state were responsible for the treatment and curative process entrusted to the imperial psychiatrists' scientific community. Even if issues of physical violence or coercion against patients arose in the Zemsky (regional) or empire-wide congresses (the First, Second, and Third Congresses of Do- 
mestic Psychiatrists; the Russian Congress of Psychiatrists held in memory of Sergei Korsakov), they could not be considered separately from the question of what the humane treatment of patients meant. ${ }^{1}$ My assumption is that this situation was possible for two main reasons. First, psychiatry in the Russian Empire was in an ongoing process of formation as both a science and an institution, unlike, for example, "Foucault's France." The awareness of the need for distinctive care for the mentally ill in the empire emerged during the reign of Peter III and Catherine II. Until the 1860s, patients had mostly been kept either with their families or in monasteries (of course, this is not relevant for the capital cities of St. Petersburg and Moscow). Many questions at the end of the century remained unclear, such as psychiatry's relations with the state, the need for comprehensive empire-wide legislation covering all categories of the mentally ill, and the primary and specialized types of mental health care necessary for the multinational population of the empire. Secondly, close cooperation with European scientific and medical thought on the one hand, and the cultural and territorial distance between Russian and its overseas colleagues on the other, allowed for the development of a situation in which Russian psychiatrists regularly needed to discuss, assess, and verify their counterparts' healing practices before their large-scale implementation into the soil of social and cultural diversity of the empire. Therefore, some particular or unchanging "background" practices that served as a prerequisite for the formation of a unified, stable type of disciplinary or coercive discourse indeed could not occur in Russia. In other words, more than the French or German, Russian psychiatrists were in the flexible position of "permanent observers," scrutinizing and critically reflecting on the ideas, practices, and diagnoses borrowed from abroad.

From this standpoint, such a research perspective avoids the "disciplinary" sketchiness of Foucault, and highlights Russian imperial psychiatry from an unusual angle as a contradictory and comprehensive set of doctors' beliefs and institutional practices that cannot be simply reduced to the logic of the previously mentioned reading of this history. One should emphasize

\footnotetext{
1 A number of concepts that are present in the psychiatric discourse of the time are associated with forcible treatment of the mentally ill, for example: "forced restraint," "constraining measures," "coercion," "restrant" in bed, matron hands, in the bathroom, etc. The Russian psychiatrist V. I. Levchatkin even writes about "barbaric violence" as an extremely vague concept and a complex of medical practices associated with it in Russian and European psychiatry in general. (See Levchatkin 1903, 106-107).
} 
that Russian imperial psychiatrists did not blindly follow German, English, or French approaches and healing procedures but rather critically considered them before employment.

\section{Violence and Humanism as Categories of Self-Analysis among Russian Psychiatrists}

By the last quarter of the nineteenth century, Russian psychiatry was experiencing rapid growth, both through the emergence of entirely new medical institutions and through the consolidation of existing professional communities in St. Petersburg and provincial educational centers. Psychiatric knowledge acquired the status of scientific and university-based knowledge. Independent departments of psychiatry were opened at medical faculties in the imperial universities of Kazan (1875), Kharkov (1877), and Moscow (1884). The reform of the provincial departmental ("prikaznyh") psychiatric hospitals, conceived in the Medical Department of the Ministry of Internal Affairs under the leadership of A.E Timashev in the late 1860s, was coming to its end. However, since the late 1840s in the same department under the direction of E.V. Pelican, the government conceived a new reform project for the transformation of psychiatric institutions in accordance with the well-developed European models. The reform entailed the construction of the Kazan District Hospital (1869), the first of its kind, and similar projects in Odessa, Kharkov, Vilna, Moscow, Petersburg, Tomsk, and Eastern Siberia. This transformation of the Institute of Psychiatry in Russia, both in prestige and in medical-practice, coincided with enlightened beliefs of the curative power of humanistic principles of treatment proposed by Philippe Pinel in France and John Connolly in England. In Madness and Civilization, Foucault proposed a reconsideration of Philip Pinel's reform as a precursor of the era of humanism in nineteenthcentury psychiatry, tearing off the chains of the mentally ill and putting an end to the physical abuse of patients. However, in actual practice, Pinel and his followers widely used measures of physical restraint in French hospitals. As a consequence, "it seemed to me that one could not ascribe Pinel's reform to humanism, because his entire practice was still permeated by something like violence ....," as Foucault underlined it later in his lecture at the Collège de France (Foucault 2006, 14). Almost every scientific article written by a Russian psychiatrist in the middle of the nineteenth and early twentieth centuries begins with the image of unlocking the shackles of the mentally ill as the 
symbol of a new era in the evolution of scientific psychiatry. Yet, one could argue that an appeal to Pinel's ideas was not a sign of isolative practices or intricate "dispositions of power" being suppressed; instead it may have been a kind of ritual, a way of speaking or reflecting on the limits of humane/coercive norms, practices, and diagnoses within psychiatric power. The symbol of Pinel's humanism served as a critical tool for further questioning: how else could one relieve and improve the environment, conditions, and permanent needs of patients held in the bleak reality of asylums' everyday life?

In his famous article "On the problem of a non-restraint regime," published after the First Congress of Russian Psychiatrists, Sergei Korsakov wrote: "Since the liberation of lunatics has begun, the more knowledge doctors acquire on the care of the mentally ill and the further science explains the properties and nature of mental illness, the more the principle of liberation is carried out. The first powerful impetus for it was given in 1792 by Pinel" (Korsakov 1887, 397). Korsakov considered humane treatment to be a subsequent reversal aiming at the liberation of patients, which consisted of the following components: 1) the welcoming and calm handling of the mentally ill in order to be closer to his/her needs and, first and foremost, to see him or her as a human and not as a prisoner; 2) well-trained and morally stable personnel (even guards and matrons). Within the non-restraint regime, the staff of the hospital must keep in mind that they should not mechanically restrict or bind the inmates, but take care and control them; 3 ) daily walks in the fresh air and short handicraft sessions: 4) a healthy and low-fat diet; 5) all sorts of entertainment (board games, billiards, outdoor games, etc.) and religious holidays (Easter, Christmas, etc.). Entertainment as a remedial measure was widely used in European and Russian psychiatric practice since the 1840s. Thus, the non-restraint regime, which included the elimination of shackling and straitjackets, and the opening of chamber doors (the second wave of non-restraint regime was the "open door system" that had been practiced in England and partially in Western Europe since the middle of the nineteenth century), suggested a range of measures that would free the patient from rigid hospital discipline.

However, at the same time, a critical question was raised: if the regime permitted a variety of freedoms, would the mentally ill still be oppressed? In other words, would the violence be secretly hidden or would it actually change in psychiatric practice? Here Korsakov noted that the majority of European psychiatrists still insisted on binding patients with lightweight "Magnan" camisoles with buttons at the back. In his study of the polemical debates between 
European and American psychiatrists, Korsakov came to the conclusion that, in most cases, binding did not bring any disciplinary or therapeutic results even for patients who were difficult to treat, such as those who were unkempt or rioutous. He claimed a few arguments against the "non-restraint" system. Based on his own experience and the experience of his Western colleagues, he came to the following conclusions: 1) patients that require binding eat less when freed (not proven); 2) binding is recommended for onanists (not proven); 3) binding is recommended as a therapeutic, disciplinary measure that subordinates the patient to the power of the physician. This final argument was also questionable because of the lack of confirmation of its effectiveness (Korsakov 1887, 433). The author concluded the report by advocating for the absolute necessity of implementing the non-restraint regime throughout the empire. If the director of the hospital was personally interested in it, and if maids were well-trained and controlled by the head physician, cases of restraint would be reduced to a minimum, and the straitjacket would be only used in extreme situations and such cases would always be registered.

Korsakov's report provoked a stormy debate among physicians. Dr. Dranitsin from St. Petersburg decided to put the question differently: was it only physical restraint, which of course had to be applied in psychiatric practice, or was there a complex of measures for the humane treatment of the mentally ill? Could the non-fulfillment of the capricious desires of patients be considered oppression? According to Dranitsin, restraint leads to low morale in the internal order of the hospital, and "to give freedom to the patient within the institution, to treat him as a human being and fulfill his desires is actually genuine humanity, which would not at all be disturbed by the fact that, if necessary, a strait waistcoat could be applied" (Dranitsin 1887, 437).

Another psychiatrist from St. Petersburg, P. Y. Rosenbach, supposed that abandoning physical violence would undoubtedly be an ideal to which all the psychiatrists should aspire. However, he was surprised by "the claim for the absolute deployment of the non-restraint, exposed by some psychiatrists, mostly in Western Europe, as an obligatory clause for a model psychiatric institution" (Rosenbach 1887, 438). Based on his observations of the patient experience in foreign mental hospitals in Berlin and London, the author doubted that this model was approapriate: "What is better? The absence of any confinement, but at the same time locking the riotous half-naked patients in small isolated rooms with stone floors, covered with decomposed urine?" (Rosenbach 1887, 438). The misunderstanding lay in the fact that, from the humanistic point of view, binding the patient was considered a flagrant abuse, 
which was absolutely unbecoming of a doctor. However, eliminating violence against the mentally ill might mean, in one instance, refusing to accept a patient to the institution, while in another, contributing to a patient's death by starvation if he refused to eat. Rosenbach's remarks were met with harsh criticism, which he fended off with the following argument (1887, 439): "Straitjackets should not be considered monsters, and the doctors who use it should not be regarded as executioners."

The future director of the Medical Department of the Interior Ministry, L. F. Ragozin, objected to Rosenbach's conclusion (Ragozin 1887, 439): “I, on the contrary, argue that the doctor should consider the straitjacket a monster, and he should consider himself an executioner if he uses it." Ragozin (1887, 436), the second director of the Kazan district hospital, raised another essential question on the role of medical personnel: "By whom and how will we replace those restrictive measures, which are intended to warn the well-known devastating actions of the patients?" If the doctor could always be with the mentally ill, if he lived among them, then the value of this regime would be undeniable. But if not, with the maids trained so badly, it would transform into evil - the psychiatrist noticed. In the first place, according to Ragozin, it was necessary to create stable, well-trained personnel and avoid staff turnover, which interrupted the routine of hospitals' everyday life. During the Assembly debate on the issue, he proposed the creation of a nationwide central fund of pensions for maids, as this measure could be the best tool for retaining the permanent staff of officers and nurses. It should be noted that the pension insurance program for different categories of servants who worked in the Kazan District Hospital (today's Kazan Republican Psychiatric Hospital) for more than twenty-five years, was established in 1889 , which is much earlier than in the other psychiatric asylums of the empire. The first director, Aleksandr Freze, initially introduced the non-restraint regime and the open-door system into the daily life of the Kazan District Hospital in 1869, the year of its foundation.

\section{The Kazan District Hospital as a Symbol of the Non-Restraint Regime in the Russian Empire}

Since the beginning of the Kazan District Hospital, all patients were allowed to wear casual, everyday clothes as the first rule of the non-restraint regime. According to Frese, the patient must have access to ordinary things, even for 
the reason that he was placed in the hospital "against his will" (Frese 1880, 81). Usual hospital uniforms such as striped gowns, caps, large caps, etc. were abolished. First-class patients were allowed to use their own clothes and underwear, or in a case of lack of sufficient funds, they were supported by the hospital. Garments that belonged to the institution did not differ from the clothes worn by people outside of the institution. The clothes for the second-class patients were of a national nature and were diverse to a certain extent (Frese 1880, 23). "For example, for the second-class patients (especially women) the dresses were not the same on holidays and weekdays-a circumstance not devoid of a psychological meaning and impact on the patients," the first director of the $\mathrm{KDH}$ wrote in his report (Frese 1880, 23). In each monthly medical report on the activities of the hospital a full graphic summary covering not only the history of the patients' diseases, their diagnoses, and general mental condition, but also statistics concerning the estate, religious, and national affiliation of each patient. For many years, they treated Russians (Orthodox), Tatars (Muslim), Germans (Lutherans, Catholics), Chuvashs, Poles (Catholics), Armenians (Arabic-Gregorian confession), Greeks, Latvians, and dozens of Inorodtzi. The majority of residents were represented by Russians and Tatars respectively. Depending on the religion, the hospital celebrated various feasts like Easter and Maslenitsa for Orthodox inmates or Korban-Bairam for Muslims with cultural and local elements on behalf of the mentally ill from each precise national group. The hospital also had a rustic Orthodox church, a Muslim mosque, and a shared prayer place for other confessions on its property.

In addition to making use of their free time to engage in various amusement classes (card games, checkers, chess, reading books, and playing musical instruments), psychiatrists also sought to develop their creative talents for drawing, handicrafts, theater acting, etc., in order to improve their mood, distract them from evil thoughts, and broaden their interests.

Entertainment for the patients was arranged almost every Sunday and on public holidays: dance evenings (winter and autumn), picnics and walks (spring and summer) in the lower garden; also military bands were invited for their amusement. There were performances in which leading roles were played by actors and actresses of the local theaters, as well as amateurs. Also, there were performances in which artists, directors, promoters, etc., were only the patients themselves, under the direct guidance and supervision of one of the keepers. (Medical-Economic Report 1898, 28) 
It is also known that during L. F. Ragozin and V. I. Levchatkin's administration of the hospital, the mentally ill-mostly stable and recovering firstclass patients-published their own magazines, Star and Comet. There the patients described their handicraft workshops and the handmade things they made, and even wrote humorous poems about the hospital. In one description of daily life in the Kazan District Hospital, an observer noted: "In the comic section of the Star not only the life of the hospital is described, but also the politics, with a touch of a moderately liberal attitude to it. They write about the 'Duma,' the parties, and prominent politicians. Most of the publications of a particular 'Mr. O-n' are written in verses. Most poems are utterly rational" (Kratoe opisanie 1913, 92). The intention of the magazines was to demonstrate to the patients the existence of a cheerful, reasonable, real world, with its daily problems, etc. The main therapeutic purpose was to distract inmates from the irrational world of spiritual thoughts and delusions and usher them back into the world of efficient, rational, daily routine practices.

Thus, thanks to the development of patients' creative abilities (theater performances, concerts, religious and national celebrations), individual handicraft skills (embroidery, painting, bookbinding, workshop work, gardening, etc.), and deep involvement in these activities by patients of different strata and social groups, Kazan, in a certain sense, appears as an "empire of lunatics" - a small reflection of the larger Russian Empire, where heterogeneous communities had to closely coexist with each other regardless of religious, national, or any other local affiliation.

\section{Russian Psychiatrists on the Problem of the Implementation of "Bed Rest" in the Russian Empire}

At the beginning of the twentieth century, experimental modes of non-restraint and the open-door system gave way to keeping patients in beds. The method of using the bed as a therapeutic tool for controlling patient behavior had become increasingly popular among European and Russian psychiatrists. Of course, bed therapy had been used before, but at this moment psychiatrists "rediscovered" the disciplinary and medical features of the bed against "epileptic," "untidy," "riotous," and "melancholic" patients. The Wachabteilung (supervisory departments of bed rest) was first organized as a pilot project by German psychiatrists Albrecht Paetz in Alt-Shebrits near Leipzig in 1880, by Scholz in 1876, by Gudden, and others. In Russia, A. V. 
Timofeev and V. I. Levchatkin first applied it in the Alexander III Hospital in St. Petersburg, and in the province it was first applied by A. A. Govseev in Zemsky Psychiatric Hospital in Ekaterinoslav (Osipov 1900, 599-600). Subsequently, the third Director of the Kazan District Hospital, Vladimir Levchatkin, semi-implemented this regime after a lively exchange at the Seventh Congress of the Society of Russian Physicians held in memory of N. I. Pirogov in Kazan in 1899.

At that time, "bed rest" in psychiatric practice was understood as the long-term retention of an excited patient in bed combined with medication (narcotic sleeping pills like chloroform, opiates, and apomorphine), wrapping them in wet warm sheets, compresses, baths, and washing in so-called Charcot's showers. Many doctors considered such a practice as ushering in a "new era" of development without isolating psychiatry, and as "almost a panacea for the treatment of all forms of mental illness" (Glushkov 1911, 834). The first German and Russian theorists recommended widespread implementation of the bed regime for the following reasons: 1) it allowed the restless and untidy patients in the general wards to "dissolve" with the calmer ones; 2) it reduced the level of physical violence among personnel towards patients, because the latter spent most time of the day in bed; 3) the patients learned to see themselves as sick or mad, and got used to the role of "victim" and, therefore, became aware of their diseases supposedly faster, while the doctor and the staff were seen in the role of health care workers-those representing the power that could curb illness and subdue the patients to treatment (so-called "hospitalism syndrome"); 4) most importantly, the psychiatric asylum, thanks to the symbolic status of the bed regime, would be equated with any regular somatic hospital where there were the sick and the "white robes," an everyday schedule, daily medication, etc.

Many major Russian psychiatrists, like V. M. Bekhterev, N. A. Glushkov, V. P. Osipov, and V. I. Levchatkin were quite skeptical about the healing capacity of the bed regime and its popularity among their European and Russian colleagues. After their own experience and traineeship in Germany, L. V. Trapeznikov and the senior intern of the Kazan District Hospital, N. A. Glushkov, reported that when the bed regime was applied without any exceptions to all newly arrived patients, the use of staff or other means to force them to remain in bed was nothing but "a huge step backwards in the treatment of the mentally ill" (Glushkov 1911, 834). The theory of allegedly successful "dissolution" of violent patients into the environment of calm patients showed completely different results in practice. Restless patients "infected" the calm ones with 
their restlessness, which led the hospital regime to uncontrolled consequences. The bed system could not be applied to paranoids, who suffered from it even more. During bed rest, patients lost weight, and no significant improvements in their mental state were observed. The regime provoked an increased level of masturbation. The daily amount of sleep increased, so the patients slept less at night. The best way of using the bed regime for all categories of the mentally ill, including the violent and the restless, would be in separate departments and would not involve shackling or any type of violence. The indications of the bed regime were to be strictly individualized according to the mental disorder of each patient (Glushkov 1911, 835).

Viktor Osipov, professor in the Department of Psychiatry at the Medical Faculty of Kazan University, made a thorough analysis of foreign literature and personally studied the use of bed rest in the women's section at the clinic of mental diseases at the Imperial Military Medical Academy in St. Petersburg. He came to the same key conclusions: bed treatment had entirely different effects on different types of patients. For some it was beneficial, for others neutral, and for others extremely harmful. If the mentally ill did not lose a lot of weight and his/her sleep schedule was unaffected, then it could be applied; otherwise, it was contraindicated. The bed regime did not improve sleep and did not exclude the use of narcotic drugs. Osipov was perhaps the first at that time to draw serious attention to the syndrome of hospitalism: "Some patients are looking for an excuse to lie down during the day or ask to be laid down again." That was a dangerous trend, so they should not be kept in bed for a long time and should be returned to a normal schedule at the first opportunity. Thus, Glushkov concluded that although at the beginning of its popularity, the bed regime was considered almost the last and best word in the treatment of mental illness, critical analysis of it in the later works of Russian psychiatrists proved the contrary (Glushkov 1911, 836). In 1896 at a meeting of the St. Petersburg hospital, V. M. Bekhterev, former chief physician of the Kazan District Hospital, "revolted" primarily against using the bed regime as a pattern for all categories of the insane. In his opinion, it should be employed by the principle of strict individualization of the patient and without any coercive measures and drugs (Glushkov 1911, 833).

Thus, a brief analysis of the most influential discussions about the choice of a particular type of medical treatment shows that it was not just an unconscious transfer of Western models or a veiling of the violent 
nature of the patient's disobedience in Foucault's sense, but an ambiguous, thoughtful, careful process of adoption of therapeutical standards. Imperial psychiatrists tried to spread the ideas of their foreign colleagues widely, but at the same time they critically analyzed these methods when adopting particular practices. They doubted the bed regime, considering it a step backward, and they seriously investigated the need for comprehensive treatment along different paths. With the development of psychiatry within the Zemstvo (local self-government) starting in the late 1860s, among Russian Zemsky psychiatrists (N. N. Bazhenov, M. J. Drozness) there was a call for the decentralization of mental health care for the population. According to the claims of many Zemsky doctors, the central district or provincial hospitals were not able to cope with the task of treating all patients throughout the empire. There was a need for more flexible and dispersed practices that would correspond with the geographical, religious, and social conditions of the imperial variety. The idea of decentralization was represented by different types of psychiatric institutions: patronage (the patient stayed in a peasant commune under the supervision of a doctor); and family and colonial (agricultural) madhouses (the same principle as a patronage, but with an enormous amount of mentally ill patients and some agricultural work) (Gakkebush 1908, 15-18).

In 1911, Valentin M. Gakkebush, the young Zemsky psychiatrist from Kharkov province, went abroad in order to study the "strong" asylums for the criminally insane. German psychiatric hospitals Dalldorf and Buch made a bleak impression upon the Russian doctor. He came to the sad conclusion that these institutions did not differ from ordinary prisons in terms of solitary confinement regarding management and nursing care: "The entire history of Russian public medicine, the psychiatric traditions of the zemstvo and its ideals reinforce the belief that Russian social psychiatry will not follow the same path. For us, this way is alien; it does not correspond with the spirit of humanity which is used by Russian psychiatrists as a basis for the free regime of psychiatric hospitals" (Gakkebush 1911, 259). All these reinforcements reveal serious self-reflective work emerging in the personality of the pre-revolutionary psychiatrist in Russia. Either questioning himself both as a doctor and a humanist or clarifying the boundaries of violence against the patient, the physician stays in the state of critical self-analysis and considers different sides of displays of psychiatric power. 


\section{Conclusions}

The purpose of this article was not to argue that psychiatric power in the Russian Empire appeared more humane than or not as violent as in, for instance, nineteenth-century France as represented by Foucault. Of course, violence, isolation, and the confinement of patients took place there, as did racial explanations concerning the degenerative nature of madness, as in P. I. Kovalevsky's "Caucasian cretinism" (Kovalevsky 1903, 195), or in a broad clinical picture of other nations, such as Russians, Bashkirs, Ukrainians, Jews (Mogilner 2016). A series of scandals occurred around the Hospital of St. Nicholas in St. Petersburg, the notorious Saburov's dacha in Kharkiv, and in the Vilna District Hospital for several years, which thanks to the efforts of many doctors, were publicly denounced (Vejnshtok 1907). Among them was a new director of the Vilna District Hospital, N. V. Krainskii, who was famous in psychiatric circles. In 1900, close to the main housing of the Kazan District Hospital, a new outhouse for political prisoners was built, a fact that had shaken the doctor's convictions on the emancipative treatment of masses, and dramatically changed the fortunes of the non-restraint regime ("O pereustrojstve" 1908).

Even taking into account Chekhov's well-known Ward No. 6, one could nevertheless argue that in the "backdrop" of this psychiatric power, in the sense of Dreyfus and Rabinow (1983), we can see a prominent set of characteristics of the imperial psychiatrist that is conspicuously different from the Soviet and contemporary ones. Through discussions of the non-restraint regime, bed rest, and the decentralization of the psychiatric system, the physician problematized questions of violence, confinement, and the physical restraint of the mentally ill, while at the same time redefining the boundaries of his professional ethos. When the political repressions provoked by the murder of Alexander II began, St. Petersburg doctors tried to denounce the revolutionist Arcadii Tyrkov as insane and sent him to the prisoner department of the Kazan District Hospital to examine his mental capacity. Kazan psychiatrists did not detect any signs of "psychopathic insanity" during the six months of thorough examination of the patient. Moreover, they protested against their metropolitan colleagues, whose report against Tyrkov had been a pure fabrication with a political aim of classifying a healthy person as mentally ill (Iangulova 2005, 20). Such a situation was entirely inconceivable in Soviet psychiatry, and, especially in the Brezhnev-Andropov period, the same is true for contemporary Russia as well (van Voren 2013). 
Researchers still have to answer the question thoughtfully: not why, but how did a period of robust self-reflection and self-analysis of pre-revolutionary psychiatrists give way to dutiful obedience to the state? At the end of the 1930s, scientific communication and the exchange of knowledge, practices, and physicians were interrupted, and the open-minded dialogue between Russian and European psychiatrists became impossible. At the same time, when the RSFSR government moved toward a policy of total control over all spheres of life, healthcare was seen as a powerful instrument for controlling the masses and especially dissidents during the 1960s and 1970s. Whereas the Institute of Psychiatry in Soviet Russia regularly functioned as a cyclical suppressive system bounded by its national ties and geography, the only real force capable of breaking the vicious circle of psychiatric abuse through the language of self-analysis was the dissident movement (Reich 2014). In numerous poems and texts, samizdat and tamizdat, and especially in Bukowski and Gluzman's well-known "Manual on Psychiatry for Differently Thinking People" primarily dedicated to practicing psychiatrists, dissidents were trying to redefine the punitive legitimacy of psychiatric power as has been persuasively shown by Rebecca Reich in her article "Inside the Psychiatric Word: Diagnosis and Self-Definition in the Late Soviet Period" (Reich 2014). While, in pre-revolutionary times, psychiatrists furiously debated the diagnoses of Kraepelin, Krafft-Ebing, or Morel, Soviet psychiatrists obeyed the "silent" and only official classification of constitutional psychopathies formulated by P. Ganushkin. This classification was officially used in the Russian Federation until 1997, after which the profession adopted the international classification of diagnoses, the ICD-10. Consequently, the generation of psychiatrists formed in the Soviet period of total dependence on the state was not able to radically question their therapeutic standards (van Voren 2010).

It is no mere coincidence that I refer to the pitiful sight of mental health services in contemporary Russia in both the introduction and the conclusion. Even if this study could be accused of recycling Foucault's "history of the present," the goal here was not to reveal the already-familiar face of modern Russian psychiatry, but rather to show its reflectively thoughtful former state. 


\section{REFERENCES}

Archangelsky, Pavel Arsenevich. 1887. "Otchet po osmotru russkih psihiatricheskih zavedenij, proizvedennomu po porucheniju Moskovskogo gubernskogo zemskogo soveta" [Report on the inspection of Russian psychiatric institutions, commissioned by the Moscow Provincial Council]. Moscow: Izd. Moskovskogo gubernskogo Zemstva.

Beer, Daniel. 2008. Renovating Russia: The Human Sciences and the Fate of Liberal Modernity, 1880-1930. Ithaca, NY: Cornell University Press.

Brown, Julie Vail. 1981. "The Professionalization of Russian Psychiatry: 1857-1922." Ph.D. dissertation, University of Pennsylvania.

Castel, Robert. 1994. “Problematization' as a Mode of Reading History." In Foucault and the Writing of History, edited by Jan Goldstein, 237-52. Oxford: Blackwell.

_ 2001. "Mishel Fuko i sociologija: k 'istorii nastojashhego"' [Michel Foucault and sociology: The "history of the present"]. In Michel Foucault $i$ Rossia [Michel Foucault and Russia], edited by Oleg Kharkhordin, 33-45. Saint Petersburg, Moscow: European University of St. Petersburg, Letnii sad.

Dreyfus, Hubert Lederer, and Paul Rabinow. 1983. Michel Foucault: Beyond Structuralism and Hermeneutics. Chicago: University of Chicago Press.

Dyakov, Aleksandr Vladimirovich, and Olga Aleksandrovna Vlasova. 2008. "Mishel Fuko v prostranstve kliniki" [Michel Foucault in a clinical space]. Chora. Journal of Modern Foreign Philosophy and Comparative Philosophy 1: 50-62.

Engelstein, Laura. 1992. The Keys to Happiness: Sex and the Search for Modernity in Fin-de-Siècle Russia. Ithaca and London: Cornell University Press.

Foucault, Michel. 1965. Madness and Civilization: A History of Insanity in the Age of Reason. New York: Pantheon Books.

_ 1984. "L'intellectuel et les pouvoirs (entretien avec C. Panier et P. Watté, 14 mai 1981)." La Revue Nouvelle 40, no. 10: 338-43.

— 2006. Psychiatric Power: Lectures at the College de France, 1973-1974. Basingstoke, Hampshire, New York: Palgrave Macmillan.

Freze, Aleksandr Ustinovich. 1880. Pervoe desjatiletie Kazanskoj okruzhnoj lechebnicy vo imja Bozhiej Materi vseh skorbjashhih (1869-1879) [The first decade of the Kazan District Hospital in the name of The Mother of God of all grieving]. Kazan: University Press.

Gakkebush, Valentin. 1908. "Decentralizacija psihiatricheskoj pomoshhi naseleniju Harkovskoj gubernii" [Decentralization of mental health care for the population of Kharkov Province]. Modern Psychiatry 1: 15-18.

_ 1911. "Krepkie' otdelenija v russkih obshhestvennyh psihiatricheskih bolnicah" ['Strong' wards in Russian public psychiatric hospitals]. Modern Psychiatry 5: 254-260.

Gerasimov, Ilia, Sergei Glebov, Aleksandr Kaplunovski, Marina Mogilner, and Aleksandr Semyonov. 2005. "Languages of Self-Description of Empire and Nation as a Research Problem and Political Dilemma." Ab Imperio 1: 11-22.

Glushkov, N.A. 1911. "Uhod za bespokojnymi, neoprjatnymi i zaraznymi dushevnobolnymi po dannym russkih psihiatricheskih zavedenij” [Care for restless, unkempt, and infectious mentally ill according to Russian psychiatric institutions]. Nevrologicheskii Vestnik 18: 820-52. 
Iangulova, Liia Vilevna. 2005. "Psihiatrija i vlast: formirovanie psihiatricheskoj jekspertizy na primere Kazanskogo Okruzhnogo Doma Umalishennyh (KODU 1)" [Psychiatry and power: The formation of psychiatric expertise on the example of the Kazan District Madhouse (KDM 1)]. In Fenomenologiia vlasti v Rossii: gosudarstvo, obshchestvo i individualnaia sudba [The phenomenology of power in Russia: State, society, and the individual fate]. Final Report of the Saratov Interregional Institute of Social Sciences. Grant No. KI 137-3-03.

_ 2007. "The Osvidetelstvovanie and Ispytanie: Psychiatry in Tsarist Russia." In Madness and the Mad in Russian Culture, edited by Angela Brintlinger and Ilya Vinitsky, 46-58. Toronto, Bufallo, London: University of Toronto Press.

Jones, Colin, and Roy Porter. 1998. "Introduction." In Reassessing Foucault: Power, Medicine, and the Body. London and New York: Routledge.

Karatelnaja psihiatrija $v$ Rossii. Doklad o narrushenijah prav cheloveka $v$ Rossijskoj Federacii pri okazanii psihiatricheskoj pomoshhi. 2004. [Punitive psychiatry in Russia: Report on the violations of human rights in the Russian Federation in the provision of psychiatric care]. Moscow: International Helsinki Federation for Human Rights.

Kazanskaia okruzhnaia lechebnitsa dushevnobolnykh. Kratkoe opisanie zhiznedeiatelnosti Kazanskoi okruzhnoi lechebnitsy dlia dushevnobolnykh: 1913 g [Kazan District Mental Hospital: A brief description of the Kazan District Mental Hospital's activities: 1913]. Kazan: Kazan District Mental Hospital.

Kharkhordin, Oleg. 2001. "Fuko i issledovanie fonovyh praktik" [Foucault and the research of background practices]. In Michel Foucault $i$ Rossia [Michel Foucault and Russia], edited by Oleg Kharkhordin, 46-81. Saint Petersburg, Moscow: European University of St. Petersburg, Letnii sad.

Kola, Dominic. 2001. "Fuko i Sovetskij Sojuz" [Foucault and the Soviet Union]. In Michel Foucault i Rossia [Michel Foucault and Russia], edited by Oleg Kharkhordin, 213-238. Saint Petersburg, Moscow: European University of St. Petersburg, Letnii sad.

Korsakov, Sergei Sergeievich. 1887. "K voprosu o ne-stesnenii" [On the issue of nonrestraint]. Proceedings of the First Congress of Russian Psychiatrists, 397-446. Saint Petersburg: Publishing House of M.M. Stasjulevich.

Koshar, Rudy. 1993. "Foucault and Social History: Comments on 'Combined Underdevelopment.' The American Historical Review 98, no. 2: 354-363.

Kovalevsky, Pavel Ivanovich. 1903. "Protokol ocherednogo zasedanija O-va 26 oktjabrja 1903" [Report of the regularly scheduled meeting of the Society, October 26, 1903]. Nevrologicheskii Vestnik 11: 4.

Levchatkin, Vladimir Ivanovich. 1903. "Po voprosu o lechenii vlazhnymi obertyvaniiami v Kazanskoi okruzhnoi lechebnitse" [On the issue of treatment with wet wraps in the Kazan District Hospital]. Russian State Historical Archive, Fond 1288, Inventory 13, Source 5.

"Medicinsko-hozjajstvennij otchet" [Medical and economic report]. 1898. National Archive of the Republic of Tatarstan, Fond 326, Inventory 1, Source 286.

Mogilner, Marina. 2010. Review of "Beer. D. Renovating Russia: The Human Sciences and the Fate of Liberal Modernity, 1880-1930". Kritika: Explorations in Russian and Eurasian History 11, no. 3: 661-72. 
2013. Homo Imperii: A History of Physical Anthropology in Russia. Lincoln: University of Nebraska Press.

- 2016. "Racial Psychiatry and the Russian Imperial Dilemma of the 'Savage Within.” East Central Europe 43, no. 1-2: 99-133.

“O pereustrojstve i prisposoblenii zdanija 'Fermy' dlja dushevnobolnyh i ispytuemyh arestantov. Tom 1-j. Nachalos 18 oktjabrja 1908 goda. 1908.” [On the reorganization and adaptations of the building "Farm" for the mentally ill and the tested prisoners. Volume 1. Started in $18^{\text {th }}$ October, 1908]. National Archive of the Republic of Tatarstan, Fond 326, Inventory 1, Source 847.

Osipov, Viktor Petrovich. 1900. "Postelnoe soderzhanie dushevnobolnyh, ego primenenie i terapevticheskoe znachenie. Obozrenie psihiatrii, nevrologii i jeksperimentalnoj psihologii" [Bed treatment: Its use and therapeutic value]. Obozrenie psihiatrii, nevrologii i jexperimentalnoj psihologii 8: 597-602.

Reich, Rebecca. 2014. "Inside the Psychiatric Word: Diagnosis and Self-Definition in the Late Soviet Period." Slavic Review 73, no. 3: 563-584.

Renner, Andreas. 2011. "Issledovanija po istorii mediciny XVIII i XIX vekov na zapade. Novye perspektivy i problemy" [Studies on the history of medicine in the eighteenth and nineteenth centuries in the West: New perspectives and problems]. In Medicina Rossii v gody vojny i mira: Novye dokumenty $i$ issledovanija [Medicine of Russia in the years of war and peace: New documents and research], edited by Ljudmila Bulgakova, 213-25. St. Petersburg: Nestor-Istorija.

"S predlozhenijami i predostavlenijami G. Kazanskogo gubernatora i medicinskohozjajstvennyh otchetov za 1873 god" [With the proposals and provisions of the Kazan Governor and medical-economic reports for the year 1873]. National Archive of the Republic of Tatarstan, Fond 326, Inventory 1, Source 58.

Savelli, Mat, and Sarah Marks, eds. 2015. Psychiatry in Communist Europe. Houndmills, Basingstoke, Hampshire: Palgrave Macmillan.

Skovoroda, Egor. 2013. "Nepreodolimoe lechenie" [The irresistible treatment]. Russian Planet, March 21, 2013. http://rusplt.ru/society/kazan.html, accessed August 2017. Solomon, Susan Gross, ed. 2006. Doing Medicine Together: Germany and Russia between the Wars. Toronto: University of Toronto Press.

- 1983. Review of Russian Physicians in an Era of Reform and Revolution, 18561905 by Nancy Mandelker Frieden. 4S Review 1, no. 1: 7-10.

Van Voren, Robert. 2010. "Political Abuse of Psychiatry: An Historical Overview." Schizophrenia Bulletin 36, no. 1: 33-35.

- 2013. Psychiatry as a Tool for Coercion in Post-Soviet Countries. Brussels: Policy Department, Directorate-General for External Policies, European Parliament.

Vejnshtok, V.A. 1907. "V bolnice Nikolaja Chudotvorca (iz perezhitogo)" [In the Saint Nicholas Hospital (from a personal experience)]. Vestnik znanij no. 8-9: 10-11. 


\title{
Patients and Observers: Specific Data Collection Methods in an Interwar Transylvanian Hospital
}

\author{
Zsuzsa Bokor
}

\section{Facts and Contexts}

After World War I, Transylvania suffered heavy losses and faced different kinds of social and economic challenges. In this transitional period, some health issues, such as venereal disease, tuberculosis, and alcoholism had been considered not just public health issues but social problems that needed to be solved. Prostitution was considered responsible for syphilis and other sexually transmitted diseases. In the context of post-armistice crisis, it affected the physical integrity of the nation. Many institutions to address prostitution were founded in this period. The problem as such was not unique to Central and Eastern European countries. In this post-war period in many European countries, prostitution became a matter of public interest, but in Transylvanian regional history, it is remarkable that the issue of venereal diseases became embedded strictly within a nationalist activist framework and took on a special meaning in the process of the Romanian medical community's self-legitimization (see Bokor 2013).

It was in Transylvania that a number of doctors developed a series of draft bills on the prostitution problem, on the basis of which a whole range of institutions were created. One of the most important hospitals established was the Women's Hospital of Cluj, which is the current focal point of my research.

This article is a revised version of a chapter of my book (Bokor 2013). 
In the following chapter, I discuss a small part of the history of this larger transitional moment. The history of the Women's Hospital and the broader story of medical institutionalization will be interpreted through the activities of an individual case study. ${ }^{1}$ The specific data collection method, medical attitudes, and the doctor-patient relationship are outlined in this story as the protagonist's task was to record and to have regular contact with the prostitutes under medical supervision. I will explain the researcher's methods through the body politics and theoretical or ideological trends of the time. Although the study is primarily intended to be an institutional history, it concentrates on the data collector's personage; that is why it only partially deals with interviewees' personal life stories.

In February 1919, the Governing Council of Transylvania established a clinical outpatient network (Ambulator policlinic) in Transylvania to deal with diseases that threatened the health of the population (venereal diseases, tuberculosis, and so on) and with social problems (such as infant mortality and alcoholism). Shortly thereafter, in April 1919, they established the Women's Hospital of Cluj, an institution that specialized in the treatment of venereal disease. While the Hospital's Outpatient Unit offered temporary and transitional treatments, serious cases were treated during longer stays at the hospital. The Control Bureau (Biroul de control) was founded in 1921 and was set up in close proximity to the hospital and the Outpatient Unit. Its main charge was to trace independent (unregistered) prostitutes; to produce publicity about venereal disease; and to assist in the control of servants and infected persons. A similar special institution in Bucharest called Dispensarul de triaj was established in 1933. In Romanian medical language, "triaj" (sorting) denotes hospital departments which pre-selected patients who would be hospitalized. The clinic was subordinated to the morality police, and its duty was to reveal secret prostitution; provide hygiene publicity to prostitutes; and to control domestic servants. During one year, 2,000 medical controls were performed and 445 women were hospitalized. ${ }^{2}$

${ }^{1}$ Documents I use in the analysis are from the Bálint Zoltán Fond of the Archives of the National Széchényi Library in Budapest, Hungary: OSZK, Magyarságkutató Intézet / Teleki László Alapítvány Könyvtára (OSZK-TLI) F. 625/ K.2880/2000, 1-12.

2 Dosar pentru corespondență, Arhivele Naționale ale României, Bucureşti, Fond Ministerul Muncii şi Sănătăţii [Correspondence folder, Central Historical State Archives of Bucharest, Ministry of Labour and Health], 16/1934. 
According to 1921 regulation that led to its founding, the Office was designed to facilitate emergency and hospital services through the control and registration of patients infected with syphilis; and its main objective was to control and record both public and secret prostitutes; help them become productive women again; but also help them escape prostitution. "This office had to create a direct and operational connection between the hospital, the ambulance, the health office, and the police. (The office leader was Mr. Z. Balint)," wrote Dominic Stanca $(1925,62)$, the head of the Women's Hospital. ${ }^{3}$ Elsewhere he detailed the role that this subsidiary institution was supposed to have: "The core of the institution was the Control Office; every patient had to go there, everybody was registered and kept under permanent supervision, as long as the supervision was considered necessary" (Stanca 1929b, 539).

It is also Stanca who explained that the leader of the Control Office had relationships with other organs of power (police, church, army), through which it had indirect control over individuals. For instance, it could use personal confessions as a source of information and could persuade women to undergo a medical exam (Stanca 1929a, 355).

Zoltán Bálint, who called himself Doctor Bálint,${ }^{4}$ had an important assignment in 1920: he was appointed head of the Control Office, the subordinate and colleague of chief physician and manager Dominic Stanca. We might also say, referring to James Scott's $(1998,314)$ concept of mêtis, that he was an agent, an expert with local knowledge, who because of this knowledge was able to get close to the mêtis.

His method was unique and seemed much more efficient than a simple hospital survey: he conducted complex interviews with the inpatient population, often including biographical profiles. Letters from prostitutes leaving

3 Dominic Stanca (1892-1979) was a physician and professor at the Faculty of Medicine in the Department of Gynaecology in Cluj and head of the Women's Hospital from 1919 to the Second Vienna Award.

4 Zoltán Bálint (1898-1978) called himself a doctor but it seems that he never received a degree in medicine. After he completed his education at the Piarist high school, he enrolled in medical school in 1916, and studied there for five and a half years. (Karády and Nastasă 2004, 159). He also studied psychology and art history at the University of Cluj. He participated in the Galileo Circle of Cluj. Later he worked as a clerk, and then a scientific researcher. He was on the editorial committees of several journals and newspapers, such as Színház és Társaság, Hétföi Hírlap, and the medical journal Clinica et Laboratorium. He participated in the founding of Cluj's Psychological Research Society. In 1935, he joined the rural studies team of Professor Gusti. 
brothels and the diaries and life stories confidently passed on to the doctor were the exclusive product of his intimate relationships with female patients.

Bálint's work can be understood at the intersection of two main interests. The more decisive of the two was a scientific interest, mainly psychological and psychiatric, which was apparent especially in his methodical survey and guide for writing patients' life histories. However, perhaps more important than his psychological interest was eugenics, a leading medico-scientific movement of the period defined by its intention to regenerate the body of the nation. The result of this interest was the physician's desire to gain insight into the most hidden details of a patient's life. The second interest was Bálint's personal motivation, about which we know little. But it significantly defined the doctorpatient relationship in general, and specifically the intimate relationships he maintained with some of his patients. This intersection of interests summarizes several roles of the "researcher," from that of the precise data collector, to the interpretive psychologist; from the medical student eager to know every detail, to the confident partner and lover, all the way down to the sympathetic healer. The observer who simultaneously undertakes the roles of interviewer, participant, spectator, and data collector, also takes on various attitudes.

\section{Screening and Data Collecting: The Bálint Model}

During his work, Zoltán Bálint interviewed several hundred inpatients every year using his own questionnaire, which he called the Bálint Model, consisting of fifty questions and a long series of other surveys. It contained three major sections: the first referred to general questions on life history, family situation, childhood, and present circumstances of the interviewed; the second part described the bodily traits; and the third was a psychological test.

The questions are interrogative, probative, analytical, and categorical. The questionnaire attempts to give a clinical or medical diagnosis; it penetrates the human body and breaks it apart; it rummages through past memories, trying to create the diagnosis of an "unhealthy" psyche. Thus, one questionnaire could potentially provide full access to an individual's (medical) life story: the past (the legacy of personal behaviors and inherited features), the present (the patient's current physical characteristics and ailments), and the future (the potential for recovery and reintegration into society).

The first chapter of the questionnaire called "General part. Curriculum vitae" deals with the patient's life history. In addition to the obligatory reg- 
istration data: the patient's name, pseudonym, occupation, workplace, address, nationality, religion, and the place and date of birth (questions 1-4), it also elicits information about decisive life events. It asks questions about her parents' and the family's living conditions (questions 5-12): parents' age and conditions of their marriage (e.g., are they cousins?), the number of her older siblings (has her mother had any abortions before the patient's birth?), the parents' material situation, and the circumstances of the patient's birth (Has her mother suffered any serious psychological, physiological, or other trauma? How difficult was her birth? How did her mother feed her in early childhood?). Bálint was curious about the living conditions of the family (Whether men or strangers were sleeping in the same room with women; details about the size of the room, etc.).

Several questions are concerned with the health status of close and distant relatives, like the causes of death of deceased relatives and histories of disability in questions 13-20. This includes questions like: "do they suffer of alcoholism, syphilis, nervous or mental diseases, or tuberculosis? Are they extravagant? Deaf-mute? If they are dead, at what age did they die? What disease caused their death?" After the inventory of family relations, it surveys the "patient's" stages of childhood development. (At what age did she start talking? Walking? When did she get her first teeth? Did she have nervous problems like epilepsy, sleeping agitation? Did she scream while sleeping? Fall out of bed? Did she have enuresis? Did she continue her studies? How well did she do at school? Did she learn easily? Was she a diligent student? What were her favorite subjects? Was she often absent from school?) (questions 21-24). Then he asks about the patient's clinical history: which severe illnesses did she have? Was she involved in any accidents, etc.

Most questions refer to the patient's sexual life and the initial stage of the patient's experience as a prostitute: when, how, for how long, and with whom? (questions 26-40). Bálint included questions about her menstrual cycle; he was interested about anything related to her earlier sexual life: did she masturbate or have sexual impulses before becoming a prostitute? Who was her first lover? In what conditions did her first experience with sexual intercourse happen and why? Why did she leave the parental home and where did she go after that? Was she married? What is her husband's age, occupation, family situation? The next group of questions refers to her status as a prostitute. For example, Bálint asks when and where she began prostituting herself? Whether she had any abortions, live births? Whether she was infected with venereal diseases or had been previously hospitalized as a result of infection. 
The last few questions (41-50) inquire about the reactions of the woman to her situation, about her possible addictive behavior, and inevitable questions about criminality, suicidal behavior, drug abuse, smoking, and alcoholism. They also inquire about her savings (the amount of money put aside), and about how she might escape from her present way of life.

A formal analysis of these questions reveals that this medical survey covers even the smallest details that may have influenced the patient's employment as a prostitute. Such inquiries were no novelty in the profession at the time. Eugenics experts including Francis Galton himself employed similar methods in his work on genealogy and biography. Galton's data were the "autobiographical replies to a very long series of printed questions" (Galton $1874,10)$. Also as a result of Galton's eugenics, the questionnaire pays special attention to genetic and hereditary factors and the possible disorders of blood relations.

The attempt at an objective description of behavior and the findings that environmental stimuli and responses to them are interdependent show partial similitude with behaviorist psychology. This perspective suggests a rigorous, psychological view, which considers human behavior to be largely the result of external influences. These external influences are just as strong in the Bálint model as are the genetic factors, as proved by questions on the parental home, the parents' financial situation, the circumstances of leaving the family, and reasons for becoming a prostitute, on suicidal intentions, criminality, etc.

As I have already mentioned, the second part of the questionnaire is a physiological inventory and the third part is a psychological test. The results of the physiological and psychological tests are not concerned with the causes of the patient's past behavior, but with their effect on the present, which requires medical intervention. These methods shed even more light on the medical position, which asserts the physical and psychological degradation of deviant persons, considering them "dysgenic" like followers of eugenics.

The second part of the questionnaire is a description of the body. Its title, "Data about the Bodily Condition" shows attempts to record any anomalies in bodily proportion and size, with the implicit intention to record potential physiological signs suggesting deviance. It presents a very accurate description of the female body. After measuring the height and weight of women, all the body parts are taken into account by their description and their possible deviations or changes: the color, shape, and density of hair and body hair; the shape of the head, face, eyes, nose, mouth, teeth, ears, shoulders, and chest. Bálint makes a complete list of the internal organs as well: the respiratory, diges- 
tive, urogenital, and circulatory system, along with the endocrine glands and spleen. Major attention-so it seems-was given to the body parts that carry most signs of femininity: the head, the face, the breasts, and sexual organs. The nervous system and the related physiological characteristics such as sight, hearing, smell, taste, touch, and reflexes are treated with the same interest. This is how biological and social gender connects: in a group of women living in prostitution, they had to find the common characteristic(s) that made them different both physically and psychologically from other women. The psychological analysis lists first the doctor's conclusions based on his observation: the patient's behavior, mood, orientation and calculation skills, moral self-evaluation, sense of shame, and relationship to peers. Then it runs experiments with exact measures on a series of psychological tests that promise genuine knowledge, like in Charcot's "pathology museum" (Didi-Hubermann 2003).

The third chapter of the questionnaire, entitled "Psychological PortraitBased on the Works of Dr. G. I. Rossolimo, Moscow," contains complex psychological tests based on the methods of nineteenth-century psychologists and neurologists. On the basis of the work of Moscow-based neuro-pathologist Grigorii Ivanovich Rossolimo, Bálint also outlines the patient's psychological portrait, which allows for the measurement of various mental processes in laboratory conditions, and then performs the Binet-Simon intelligence test on them.

The survey focuses on nine cognitive and behavioral processes: attention/ concentration, willpower/endurance, memory fixation/punctuality, memory (visual, auditory memory, and number memory), perception of pictures, combination ability, invention, fantasy, and observation ability.

The tests were created for the purpose of a more thorough examination, as they promised more than simply the investigation of life conditions, as the creators of the questionnaire stated: "We think that it is only after a thorough psychological examination that we can explain the many deviances and the ease with which they perversely give themselves to anyone who desires the use of their body" (Bálint and Stanca 1924, 15).

The psychological test, in combination with the physiological test, suggests a different kind of reality than the life history interviews: that of the observer. The observed body is part of a medical and psychological knowledge that is completely different from the person's knowledge of their own body. Bálint also used the word-assembly exercise of the internationally acclaimed neurologist Pál Ranschburg (whom he considered a model), known as the inventor of the psychological tests used on people with various disabilities. 
The data collected via the questionnaires, as we have seen, served mainly to make general conclusions and generate statistics, as well as to establish a general psychological diagnosis for prostitution.

\section{Collecting Life Histories and Love Letters}

The questionnaire is completed by another, later questionnaire, which encourages the detailed description of one's biography in the form of confession. It gives the following instructions:

Take your time to think over all of your previous life, and write down everything you consider important about it. Write down your life history in such a way that you do not leave out any event, experience, or influence that had a decisive role in shaping your fate. In your writing, strive to be as honest, open, and accurate as possible. Below you will find a long series of questions. Read these through, because they are a great help in thinking over your life...

Even while collecting life histories and diaries, Bálint appears as a collector, an indirect observer; yet, almost unnoticed, he guides the confession. He speaks out of the text; he repeats questions that the "patient" has already heard during the "official" hospital observation and interview, for instance, "Why have you become a prostitute? Do you desire men, frequent sexual pleasure, or was it your life conditions, the hope of an easy income, or some other interest that made you become one?"

In this context, writing is an obligation; it is a form of confession like the church confession: it is depressing, obliging, and absolving, and without it, one will face complete exclusion and punishment. The patient is therefore obedient and at times quite helpful: "And as for the completion of the questions that are part of the analysis, I'd like to answer them orally, still, it cannot be written so well. I know you'd want to know already, but wait patiently," Médi writes in her letter. ${ }^{5}$

Writing, however, is not only an obligation, but the hope of an improvement of the situation. The patient who complies with this request thinks that,

${ }^{5}$ Letters from prostitutes. Bálint Zoltán archive. OSZK-TLI F. 625/ K.2880/2000, 12. 
by revealing her secrets, she will be absolved by the force of the confession, and her cooperation with the doctor results in "healing." "A romantic adventure happened to me as I'll explain. Those who do not believe that sinful women are able to love now can see it," Lola wrote in her biography. ${ }^{6}$

The intimate relationship between Bálint and his patients is quite problematic and blurred, mostly because of the lack of information. We have a series of love letters from female patients, but we do not know his replies. Ever since the advent of psychoanalysis, the intimate relationship of doctor and patient (the treating physician and the ill person) has been known, and even psychiatrists considered it to be an important part of healing. DidiHuberman offers a new understanding of Freudian transference when assessing the doctor-patient relationship (referring to the relationship of doctor Charcot, physician of Salpêtrière, with his patient Augustine): the hysterical woman has one single benefit from her illness, that of seduction, which is the gift of the medical gaze fixed on her because of her symptoms. The examiner in this situation of transference expects the ill woman to lend herself to the doctor's desire of knowledge (Didi-Hubermann 2003, 172).

Although in his works Bálint did not agree that only prostitutes could be held liable for venereal diseases and judged men who used the institution of prostitution, he also used his official position for personal purposes, and his personal relationships for professional aims. He proclaimed several times that men are responsible for sexually transmitted venereal diseases just like women, and they play important roles in maintaining the institutions of prostitution. "Prostitution is immoral and dangerous, and its official regulation is the legal perpetuation of this immorality and perdition. In addition, the regulation is a shameful restriction of personal freedom, and it's even unfair and one-sided because it only lies with the woman. It's dangerous because of the spread of venereal diseases, which are in close contact with it. Medical monitoring of registered prostitutes is by no means satisfactory. Besides, prostitutes with such diseases are not as dangerous as men who have sex outside marriage" (Bálint n.d, 1). He sympathized with abolitionist movements and said that "The abolitionist principles are further important because they warn of the consequences of men's inherent selfish and hypocritical morality and of the women's degradation" (1).

${ }^{6}$ Biographies. Bálint Zoltán archive. OSZK-TLI F. 625/ K.2880/2000, 10. 
It is remarkable that he speaks with such disapproval about exploited sex workers, because his research models and working methods show similar features to those he criticizes. I think that the institution, the hospital management's expectations, system, and approach, as well as well-known methods and techniques of psychology and psychiatry are certainly determinative in taking on such an omnipotent researcher role.

While women perceived this relationship as personal, Bálint played the role of the data collector: he rewrote their letters, penning most of them so as to include these arbitrarily selected texts in case studies. These transcripts usually lack the kindness of past events and thoughts referring to the women's amorous relationship. For Bálint, the non-clinical personal details are not useful for analysis and these texts change their role. Looking at Bálint's methodical work, which was performed with so much awareness, I think that this personal relationship was of great use in the acquisition of new data, and through their close relationship, these women-like Charcot's Augustinemore easily accepted their roles as models of truths.

As Bálint's hospital work shows, his personal-professional relationship is almost symmetrical to that Regina Morantz-Sanchez (2000) speaks about. These illness narratives also make a bargain between doctor and patient regarding the boundaries of health and illness; but this resolution takes place outside of the encounter between the patient and her doctor. Morantz-Sanchez does not consider this a relationship of subordination, but most often a negotiation in which both parties have approximately the same effect on the other and are mutually interdependent. In my case, however, the circumstances of those admitted to the hospital are different-nobody presents herself for examination to the Women's Hospital of her own accord, but does so based on compulsion, and the failure to do it results in punishment. The different social status of illness and deviance further reinforces this subordinate relationship.

\section{REFERENCES}

Bálint, Zoltán, n.d. A férfi része a prostitúcióban [Man’s role in prostitution]. Unpublished manuscript, Bálint Zoltán archive. OSZK-TLI F. 625/ K.2880/2000, 1.

Bálint, Zoltán, and Dominic Stanca. 1924. Studiu statistic asupra 200 prostituate [Statistical study of 200 prostitutes]. Direcțiunea Regională XI. Sanitară, Cluj, Spitalul de Femei, Cluj. 
Bokor, Zsuzsa. 2013. Testtörténetek: A nemzet és a nemi betegségek medikalizálása a két világháború közötti Kolozsváron [Histories of the body: Medicalization of national and sexual diseases in interwar Cluj]. Cluj-Napoca: The Romanian Institute for Research on National Minorities.

Didi-Huberman, Georges. 2003. Invention of Hysteria: Charcot and the Photographic Iconography of the Salpêtrière. Cambridge, MA and London: MIT Press.

Galton, Francis. 1874. English Men of Science: Their Nature and Nurture. London: Macmillan.

Karády, Viktor, and Lucian Nastasă. 2004. The University of Kolozsvár/Cluj and the Students of the Medical Faculty (1872-1918). Budapest-Cluj-Napoca: Central European University-Ethnocultural Diversity Resource Center.

Morantz-Sanchez, Regina. 2000. "Negotiating Power at the Bedside: Historical Perspectives on Nineteenth-Century Patients and Their Gynecologists." Feminist Studies 26, no. 2: 287-309.

Scott, James C. 1998. Seeing Like a State: How Certain Schemes to Improve the Human Condition Have Failed. New Haven Yale University Press.

Stanca, Dominic. 1929a. "Organizarea ambulatorului policlinic" [The organization of the outpatient polyclinic]. Clujul Medical 7: 346-55.

. 1929b. "Zece ani de la înființarea spitalului de femei şi ambulatorului policlinic Cluj (1919-1929)" [Ten years since the establishment of the women's hospital and the outpatient polyclinic in Cluj]. Clujul Medical 11: 535-46.

_. 1925. "Spitalul de femei și ambulatorul policlinic din Cluj în cei cinci ani de funcțiune (1919-1923)" [Five years of activity of the women's hospital and the outpatient polyclinic in Cluj]. Clujul Medical 3-4: 60-65. 



\title{
Contemporary Criticism and Defenses of Psychiatry's Moral-Medical Types in Light of Foucault's Lectures on the Abnormal
}

\author{
Balázs Berkovits
}

In critical social science, the analysis of psychiatry, psychology, special education, and other "psy-sciences" is incredibly important, because these disciplines and the practices relating to them are considered to play an important role in the subjugation, regulation, and transformation of subjects. What is and what should be the strategy of critical approaches when it comes to the analysis of psychiatric, psychological, criminological, etc., categories and categorized subjects? On what grounds could psychiatry and psychiatric treatment be criticized?

One of the strategies, informed by an objectivist perspective, consists of pointing out the relationship between psychiatric treatment and moral judgment or normativity. From there, one can conclude that some usages of psychiatry are not genuinely scientific; therefore, the treatment of real mental illness should be kept separate from the regulation of "deviant" or otherwise "problematic" populations; in the case of the latter, "psy-sciences" should not play a role. To put it simply, social problems must not be medicalized or psychiatrized, and psychiatry should only deal with medical issues on the basis of its own, medically defined territory.

Shall we say then that the treatment of mental illness should be morally neutral, without any basis in other people's, let alone governments', institutions', etc., exterior moral appreciation; that it should be non-judgmental in a moral sense? Certainly, criticisms of psychiatry have often highlighted the moral antecedents and/or components of diagnoses and treatment. By the 
same token, these approaches also tried to cast doubt about the scientificity of psychiatry, asserting that it rather deals with moral and not medical types. If this claim is true, then psychiatry is enmeshed with normalizing intentions and institutions, the primary roles of which are social control, maintaining "public hygiene" and discipline, the encouragement of conformist and rulefollowing behavior by the stigmatization of "perversions" and "deviance," and so on. These critical approaches include antipsychiatry, various interpretations in the realm of the history of science, but also analyses stemming from critical sociology and social constructionism.

However, it is far from certain that these types of analyses successfully support their criticism, for they often reference incoherent presuppositions and dubious epistemological criticism, which contrasts "good, scientific medical practice" to "bad, biased practices entangled with power relations." In these criticisms, what really is at stake is the scientific status of psychiatry; and when psychiatry does not prove to be scientific enough, then it is considered a discipline serving only the power interests of dominant groups and institutions. Nevertheless, in these approaches it is not outright excluded (and more often it is even asserted) that there is potential for a kind of psychiatry that deals with genuine mental illness, independently of any exterior social or moral influence. In turn, defenses of psychiatry usually tried to refute the meaningful connectedness between psychiatry and morality by simply reaffirming the medical model.

However, it should be noted that it is not possible to distinguish between bodily and mental illnesses by only taking into consideration their respective relationships to normativity and normality-contrary to the intention for example, of Thomas Szasz's antipsychiatry. It is well known at least since Georges Canguilhem's The Normal and the Pathological that even physical illness cannot be defined in a neutral, statistical, and objective manner that relies only on exterior norms, because it is always necessarily linked to the individual's own values and norms (just as in the case of mental illness): “. . a statistically obtained average does not allow us to decide whether the individual before us is normal or not. We cannot start from it in order to discharge our medical duty toward the individual. When it comes to a supraindividual norm, it is impossible to determine the 'sick being' (Kranksein) as to content. But this is perfectly possible for an individual norm" (Canguilhem 1978, 105).

This view, without referring to Canguilhem, is also echoed by philosopher of psychiatry Eric Matthews (1995, 20), who asserts that “illness' is 
a value-laden concept, since 'being ill' is by definition being in an undesirable state. In that sense, there is no difference between undesirable bodily and mental conditions: they can both be considered as 'illness.' . . . If we are to make a distinction between literal (bodily) and metaphorical (mental) illness, however, the crucial question is for whom the state is undesirable, or by whose standards." Also, continues Matthews $(1995,20)$, in spite of the fact that objectivist views on medicine are quite misleading, they are still firmly anchored in present-day reflections: "modern conceptions of health and illness imply that health is a non-moral good, and so that illness is a 'disorder' in a nonmoral sense" - a view against which Matthews forcefully argues.

From all this follows that if one, by adopting an objectivist perspective, takes psychiatry to be a strict medical science or, by taking a normative stance, a would-be medical science, then she surely repudiates any link with moral and social norms as spurious. Either she rejects any accusation of psychiatry as moral and intertwined with power relations in any way; or if she recognizes the existence of such links, she would still make suggestions to purify it, with the intention of making visible its supposedly true scientific nature. Since within this kind of framework critics and defenders of psychiatry adopt a common epistemological stance, their respective positions are not very far from each other.

However, recently other types of defenses have appeared, along with other types of criticisms. These defenses, in flagrant opposition with previous ones, try to argue for the non-contradiction between morality and rationality (Charland 2006, 2008, 2010; Zachar and Potter 2010; and in a very different vein Castel 2009, etc.). They also do not view this connectedness as problematic with regard to psychiatry's scientific status. Some of these approaches (of which I will only deal with that of Louis Charland here) state that a rational norm for mental illness can be created, which, at the same time, is not and cannot be separated from the moral component; others may even advocate for the relevance of the moral treatment of personality disorders; and the topic of moral responsibility and forensic psychiatry re-emerges as well.

It should be noted that the claim of the inseparability of moral and rational aspects also characterizes some types of criticisms as well, but these are different from antipsychiatry or social constructionism. These are approaches that neither intend to sort out the elements of morality in psychiatric diagnoses and practice, nor do they strive to prove psychiatry's irrational or unscientific character. Here, we should mention, in the first place, the genealogies of Michel Foucault and other authors inspired by him, like Nikolas Rose 
or David McCallum. Therefore, the question should be posed: how can this non-separation be some times affirmative and at other times critical? To give a tentative answer to this question, it is worth re-examining the genealogy of forensic psychiatry provided by Foucault in his Collège de France lectures on the birth of "abnormality," entitled Abnormal (Foucault 2003).

But let us consider first the traditional criticisms of psychiatry, which operate by highlighting the moral components of the diagnoses. The type of criticism exerted by the antipsychiatry of Thomas Szasz is the following: socalled mental illness is diagnosed on the basis of external behavior, including expressions of attitudes and beliefs. Szasz's argument is the following: since the behavior is the patient's own behavior, it cannot be considered as alien or undesirable to her. On the contrary, more probably it follows her norms, which might contradict the norms of society that the patient refuses to follow. Therefore, according to Szasz, psychiatry resembles much more the activity of policing and rectifying individuals considered abnormal, than a medical specialty: "the psychiatrist's task is not to improve the patient's condition in terms of the patient's own standards of well-being, but to make the patient's behavior and attitudes conform to social standards to which he or she is at best indifferent" (Matthews 1995, 21). In contrast, "a truly therapeutic attitude should be non-judgmental: that is, it should be able to set aside as irrelevant any value judgment about the patient's condition other than those of the patient him- or herself" (Matthews 1995, 22).

Furthermore, according to Szasz, psychiatry operates with a naturalistic bias, as if it was a medical specialty, by mistaking the mind for the brain. However, psychiatry could never become a medical science, says Szasz, for it has to deal with meanings, signs, modes of conduct, interpretations, rulefollowing behavior, and has to take into account the essential liberty of human action-all that is underdetermined by possible bodily processes. However, sometimes even Szasz asserts that a non-medical scientific psychiatry could exist, if a science of personal conduct existed, on which it could be based. But at other times, this scientific nature as such becomes doubtful, as if psychiatry were not and could never be a science-for it is not a natural science and does not deal with illness, that is, with something objectively given.

Szasz's main example for medicalized mental illness is hysteria and "hysterical conversion." For this kind of symptom, bodily signs symbolize personal problems. Szasz claims that contrary to the psychiatric interpretation, hysteria is an idiom in which patients communicate their genuine psychological prob- 
lems in a covert manner. Also, the actions performed under the description of hysteria may be explained by the existence of social norms: in some situations it is not possible to express one's desires or to ask for help in an open way (Szasz 1974, 145-46). But will the symbolization of hysteria become "personal and idiosyncratic" only because it is not "anatomical and physiologic"? We will see that this is far from evident.

For Szasz, bodily illnesses are events producing indexical signs as symptoms, whereas hysteria and other phenomena called mental illness are actions producing iconic and conventional signs (Szasz 1974, 120-34). Now the critique of Szasz consists in highlighting the way psychiatry transforms iconic and conventional signs into indexical signs, thereby establishing a firm causal relationship between disease and symptom. But this is a deeply flawed practice, for in most cases of mental illness, symptoms are not pre-determined and partly depend on the choice of the individual, on her more or less free intention to express the psychological and social state in which she finds herself. Therefore, these symptoms are misperceived by psychiatry.

Szasz strictly contrasts pathological to moral, body to mind. For him, there are clear, definable limits to what we could legitimately call illness. According to critical psychiatrists Patrick Bracken and Philip Thomas, for Szasz, "problems with our bodily functions are properly understood to be pathological, but difficulties with our thoughts, feelings, relationships, and behaviors are of a different order. They are not pathological, not diseases or illnesses; they are best characterized as 'moral' issues or simply 'problems in living"' (Bracken and Thomas 2010, 220). Szasz thinks that the only essential things that come forth in psychiatric treatment are the moral issues, which are pathologized and therefore misunderstood. The task for Szasz is to keep them separate from the power of psychiatry and disentangle them from external standards and judgment. This can only be assured by therapies exerted on a free and contractual basis, while psychiatry is the agent of the state inculcating biomedically naturalized moral standards.

The connectedness and desirable separation of moral and medical categories, although in a different manner, appears as well in the program of critical sociology and constructionist approaches, which intend to unmask how psychiatric treatment is intertwined with social influences, including moral subjugation and social control mechanisms. How is this constructionist criticism achieved? How do social constructionist approaches proceed when they analyze psychiatric, psychological, criminological categories, and categorized 
subjects? They do not intend to examine the nature or the supposedly inherent characteristics of psychiatric patients that would emerge due to supposedly preexisting disadvantages, impairments, or illnesses. Rather, they are curious about how these definitions or categorizations are constructed. They bracket everything that is considered to be "objective" by psychiatric categorizations, and investigate how these very categorizations come about.

The main targets of constructionist approaches have been the objectivist and functionalist analyses of social and mental pathologies considered objective. In contrast, labeling theorists or constructionists are inclined to deal with institutions of social control. In their view, deviance and the perception of deviant groups, including the mentally ill, is created by reactions to certain conduct; therefore, they refrain from formulating anything with regard to their objective reality. However, the question arises, how can the deviant/mentally ill label be criticized? What could be the basis of the critique? There are several, although implicit or unconscious strategies employed to solve this problem.

Steve Woolgar and Dorothy Pawluch, in their article entitled "Ontological Gerrymandering” written in the eighties, revealed an inherent ambiguity in social constructionist explanations. According to the authors, social constructionist researchers "elaborate the imperative to study definitions of social problems rather than the imputed conditions themselves. To do so, they employ the assumption that in many cases definitions of social problems vary while conditions (defined) do not" (Woolgar and Pawluch 1985, 216). For sure, constructionists consider these definitions of problems as morally loaded, which, thereby, distorts the perception of the conditions. Therefore, by presupposing some "stable conditions," they seem to tacitly reintroduce the reality of deviant behavior or mental illness, but before its definition as such, as a kind of preexisting reality, which could be distinguished from its morally anchored and arbitrary definition. Woolgar and Pawluch name this procedure "ontological gerrymandering." This practice could be epitomized by the formula they borrow from a constructionist researcher: "The same 'objective" condition may be defined as a problem in one time period, not in another" (Gusfield 1981, 8, cited in Woolgar and Pawluch 1985, 216). This is a kind of ontological manipulation, which renders uncertain the status of definitions by referring to a so-called more real reality. For researchers generally implied that the label or definition, as a putative characteristic, does not have a basis in reality; "putative," suggesting that it is not true or not grounded in reality. But the problem, which was never reflected upon, is the following: what is the nature of the reality to which they are supposed to be referring? For this so- 
called reality has already been bracketed by the initial methodological considerations, and therefore has never been examined by sociologists.

Applying this kind of constructionist approach to psychiatry is attractive because it makes it easier to take a normative stance, namely by the tacit adoption of a realist criterion of truth through the presumption of an everexisting reality (though structured in a specific way) that only has to be unveiled by science. However, according to constructionists, the discovery of this reality is only possible if scientific practices are not diverted by social influences. This line of thought is characteristic of Thomas Scheff, for example, who worked within the labeling paradigm. Scheff cites five case studies, where he finds "strong relationships ... between such social characteristics as class, and commitment rates, with psychiatric conditions controlled for. These five studies support labeling theory since they indicate that social characteristics of the patients help determine the severity of the societal reaction, independent of psychiatric condition" (Scheff 1974, 449, italics are mine). Therefore, Scheff not only admits that there might be a genuine psychiatric condition, but relies on it as something objective in order to formulate his critique. In fact, in the strategies mentioned, criticism can be inserted by virtue of the separation of the conditions from their definitions, for these definitions seem to be merely the consequence of the historical and social changes in the context of the defining subjects, and not due in any way to the defined objects.

Other social constructionists adopt a different strategy, denying the existence of underlying objective phenomena as such under the constructed definition. They "rely on the theoretical principle that all societal reactions might be unwarranted" (Woolgar and Pawluch 1985, 223). However, in this way, they only fail to account for the very real effects of scientific categorizations, while still tacitly (and unconsciously) referring to the already bracketed objective reality. It is philosopher of science Ian Hacking who advanced a most perspicacious critique of social constructionist talk (Hacking 1999). The inherent ambiguity of social constructionism is that it implies that construction equals non-existence or not-genuine-existence, whereas researchers only point out that the emergence of the objects in question was not inevitable: they have been created in a historical and social process. The first problem Hacking identified is the way criticism is generated. What constructionists actually demonstrate is that it would have been possible that the objects in question did not come into existence. But then they misleadingly conclude that the objects do not actually exist, or that they only exist in the minds of those persons who construct the categories. It follows that the critique of 
psychiatry could be formulated by pointing out the fictitious entities of its own creation. But of course, it is not the case that it would be contradictory to assert at the same time that the object is fabricated-it has come into existence at a certain moment, has a history-and that at this very moment it exists as something real. The process of construction does not imply at all that the object is non-existent (we could actually argue for the contrary; see, for example, Latour 2013).

Second, most of the time, social constructionists also misunderstand the things they regard as constructed. For while they usually talk about the construction of objects, in their analyses they only examine the construction of the categories and the definitions (Hacking 1999, 47). In discussions about the constructed nature of the categories, they fallaciously imply that the objects are constructed as well, along with the tacit assumption that they know how the real objects-contrasted with the "constructed" ones-look. If this is the case, then we are back to the previously analyzed problematic of "ontological gerrymandering."

Third, and most importantly, it is not all about concepts. It is also about the emergence of those objects designated by the concepts. This means that construction should be taken seriously: the psychological sciences, in spite of, or maybe due to their moral character, have an ontological role. They influence and produce parts of reality by creating not only theoretical entities, but also real ones. If this is the case, the moment of construction cannot become the locus of the critique.

Woolgar and Pawluch, by the end of their article mentioned above, ask whether it is possible to describe phenomena independently of their ontological status. And, if there is no objective element, would criticism still be possible? Therefore, the question is if criticism can be exerted without having recourse to an explicit and exterior norm, without having to take a dubious epistemological stance. In this respect, I will examine Foucault's genealogy of forensic psychiatry.

But before I do so, let me turn to some of the counter-tendencies in theoretical reflections on psychiatry, to those defenses that try to accommodate moral terms and morally defined categories with scientific formulations, thereby saving psychiatry from this type of criticism. If morals and the practice of psychiatry do not contradict each other, then psychiatry is rescued on the epistemological level-where this battle has actually been waged. In this respect, I will only cite the thoughts of the philosopher Louis Charland. According to 
him in the DSM IV, Cluster B personality disorders (but not the others) are identified through explicit moral terms and notions such as "lying," "lack of empathy," or "conning others" (Charland 2006, 119). A condition defined in this way is evidently moral, but for him, this is unproblematic. He calls his first argument for the non-separability of moral and medical kinds the "argument of identification." His second argument comes from treatment, which can be formulated like this: "there is an important difference between, say, ceasing to be depressed on the one hand and ceasing to be a liar on the other. The difference is that the first case can be seen as a cure while the second case is tantamount to a moral conversion" (Charland 2006, 122; see also Charland 2010). According to him, the "psychopathology of affectivity" is the branch of psychopathology devoted to the study of mental disorders implicating mental states associated with moods and emotions, which used to be called passions. He traces back this usage of affectivity to eighteenth-century conceptions of morality, evoking thoughts of Rousseau and Hume. Defending psychiatry's scientific quality, he also turns to nineteenth-century moral treatment and Pinel, who, according to him, "believed that the new psychopathology of the passions had to include elements of value and especially morals along with psychological terms and notions generally." Therefore:

For Pinel, "moral" often means what is mental and what, additionally, has to do with morals. But not always, since there are many instances where psychopathology is only concerned with states that are psychological and morals are not involved. Pinel saw no contradiction between acknowledging the psychological aspects of moral treatment (le moral) while at the same time insisting it had important ethical presuppositions (la morale). (Charland, 2008, 9, italics are mine)

Charland claims that medicine can contribute to ethics by showing how social and personal lapses in morality can often lead to mental illness. Charland disregards anything that could be considered as problematic in moral treatment and completely neglects the history of personality disorders. Furthermore, he asserts that according to Pinel's documentation, his "treatments based on 'moral' principles and notions in the widest psychological sense were often extremely successful" (Charland 2008, 26).

Even though we could qualify Charland's analysis as utterly naïve because it lacks historical reflection on the functions psychiatry could fulfill in different apparatuses of power, while positing some unchanged human moral 
character that can become the object of a stable science of personality, it does point to some important insights regarding the potential critique of psychiatry. Namely, it highlights the blind spots of epistemological criticisms that rely on the attitude of "purification," and intend to sort out legitimate (pertaining to "real" illness) and illegitimate (imbued with effects of power and morals) features of psychiatry.

Common refutations of, for example, the symptomatology of "antisocial personality disorder" would point out that starting from Prichard's "moral insanity," "theorists have always confused undesirable behaviors with mental aberration. The reason for the confusion between antisocial personality disorder and criminality is that there has never been a clear definition of insanity or mental disorder" (as the Sydney-based psychiatrist John Ellard put it, cited in McCallum 2004, 28). According to this claim, had there been a clear definition, this confusion would not have been possible, and the purity of "real" psychiatric diagnostics could have been preserved. David McCallum, analyzing these critical interpretations, points out that the problem formulated by them is the lack of distinction between insanity and wickedness. Also, this is precisely the point where criticism can be inserted; namely, the critique of this non-distinction. In fact, the strategy of these critical theoreticians is to assert that the fundamental distinction had been lost in the successive confusion of medicine with morals, the figures of which can be rendered as the following: Isaac Ray's (1871) "moral mania," Spitzka's (1887) "moral imbecility," Koch's (1891) "psychopathic personality," Cleckley’s (1941) "psychopath,” Bowlby’s (1949) "moral defective," and finally the first Diagnostic and Statistic Manual's "sociopathic personality disturbance" (1952). So "these (critical) ... accounts assign a prior existence to different categories of mental illness and disorder independent of their historically specific means of calculation" (McCallum 2004, 29). Therefore, these criticisms accept the existence of unhistorical psychiatric entities, which would only need to be purified from contamination by power, social norms, and morals. Once again, we are back at the unfounded epistemological criticism called ontological gerrymandering.

We saw that for Szasz, what is at stake is the recovery of some original meaning, which was supposedly lost in psychiatric treatment. He does not intend to salvage the science of psychiatry, but rather the idiosyncratic selfexpression of the individual. According to him, communication by hysteria proceeds by a somewhat autonomous series of signs that is not predetermined by some underlying illness. Yet psychiatrists wrongly interpret it, thereby distorting it. So, what is the relationship between this therapeutic activity and the 
original intention of hysterical behavior? It seems that this is a relationship of permanent misunderstanding, where psychiatry fails to attribute the symptoms to the will of expression of the individual, and constructs an underlying substance instead, that is, an illness. There is no real interplay or communication between the psychiatrist's interpretation and hysteria, and thereby no mutual influence: the psychiatrist is deaf to the real issue.

However, as we can learn it from Foucault, the problem is far from being resolved by the restoration of a kind of "hermeneutical relationship" that has allegedly been masked by the construction of (pseudo-)natural kinds, or essences. Szasz's hermeneutical approach pretends that the subject-objects of the human sciences already bear a pre-existent meaning, which is to be sussed out. However, even if Szasz does not present this meaning as substantial, he does not take into account either the entanglement of power relations or the production of knowledge. The individual, the subject of psychiatry, constructs his own subjectivity with the help of pre-established interpretative schemes, even if he is not incorporated into a coercive institutional environment. Therefore, as Foucault implies, nothing could be the adequate interpreter of subjectivity, for subjectivity does not exist before interpretation, but interpretation can only take place among power relationships.

In Foucault, we find no a priori image of a "good science." Science is examined as it is being made, and there is no explicit normative stance adopted capable of judging it. In his genealogy of the "abnormal" (Foucault 2003) - a thoroughly moral concept and object-psychiatry plays a huge part. According to Foucault, psychiatry took on a significant role in the realm of justice in relationship with some particular events, and especially with the appearance (in its psychiatric definition) of "homicidal monomania" (Foucault 2003, 119). This symptom characterizes a type of "moral monster" and the crime committed by him. In this case, the perpetrator of the crime, according to expert psychiatric assessments, is not insane; however, his act seems to be unmotivated. Outright madness is excluded, but the subject and his act still do not look rational because it is not possible to understand his reasons. Therefore, the criminal court has to look for motives in order to be able to make the act intelligible, which is now-from the beginning of the nineteenth century on-a precondition for punishment. These motives will be detected in the character of the perpetrator of the act, without which the criminal court would be helpless. According to Foucault, law has "a radically uncomfortable position" while dealing with a "motiveless act committed by a subject en- 
dowed with reason." If this is the case, the situation becomes difficult: "the exercise of punitive power can no longer justify itself, since we find no intrinsic intelligibility of the act through which the exercise of punitive power connects up with the crime. . . Consequently, it can no longer judge; it is obliged to come to a halt and put questions to psychiatry" (Foucault 2003, 116-17).

Therefore, the legal norms will be applied by the mediation of extra-legal norms, which are, in this case, the psychiatric norms, and which, in turn, create the figure of the abnormal. In the juridical sentence as well as in medical assessments, the "abnormal" character will replace the perpetrator of the crime. Extra-legal norms obey a different type of rationality, but they can be integrated into the legal machinery, thereby creating the relationship between criminality and mental illness, whereas, before, these two were radically different: the mentally ill person, by definition, was not responsible for his acts. From now on, the sentence will be based on the morally qualified personality of the criminal, beyond his acts. It is applied to the criminal, who is not perceived as someone breaching the law or as a perpetrator of a crime, but as an "abnormal," that is a morally-psychologically defined individual (the pathological nature of whom is attested by his "inclination" or even "instinct" to violate the norms). The objective of the sentence will not be limited to punishment, but will equally comprise correction-and undoubtedly, penal institutions will have an important role in the use of morally-informed therapeutic procedures. Psychiatry was invented and has always been practiced as a moral discipline; furthermore, as it emerged that its conditions of possibility were thoroughly moral, the intention of liberating or purifying it from morality simply does not make any sense.

However, the fact that psychiatry proceeds by constructions does not prove its anti-scientific character, because these constructions appear not only in the order of knowledge, but just as well in reality. Psychiatry creates the conditions under which its objects can appear as natural, as if those pre-existed its functioning. But of course, this means neither that these objects existed as such before the work of interpretation, nor that by dismissing the interpretation (the construction work) provided by psychiatry, individuals can regain their "real nature" and interpret themselves freely, without any constraints.

For these reasons, the critique's point of attack should be the fact that psychiatry produces its subjects in a certain way, rather than its epistemological status. Psychiatry cannot be blamed for epistemological fallacies, because the connection between power and knowledge cannot be disentangled. Foucault accepts that psychiatric sciences can be scientific because, for him, 
"scientific" is not a value-laden concept, while what counts as scientific is historically changing. He does not intend to criticize them by unveiling their socalled unscientificity: he does not have a normative epistemology. ". . . I believe that the problem does not consist in drawing the line between that in a discourse which falls under the category of scientificity or truth, and that which comes under some other category, but in seeing historically how effects of truth are produced within discourses which in themselves are neither true nor false" (Foucault 1980, 118). Therefore, it is not possible to investigate the nature of psychiatry as a science independently from the entities with which scientific classification deals. The functioning of the science cannot be separated from its objects on which it works-this is the sense of the interior relationship between power and knowledge. The epistemological type of critique had to turn a blind eye to this problem, for it was only able to examine constructions in the order of knowledge. In turn, it rigidly separated these constructions from the purportedly erroneously categorized "real" objects. Furthermore, it omitted the empirical examination of the latter, thereby creating an insurmountable contradiction.

In contrast, the question for Foucault is how mentally ill, handicapped, criminal, etc., populations come about as real entities, and how they are constantly transformed due to scientific classification and other scientific practices. Techniques of transformation exerted on patients can work (without necessarily being successful) because of the institutional treatment (the sentence and the modes of punishment based on the category of an abnormal sub-type), and also because individuals apply these norms to themselves, by which they form their own subjectivities. By the fact of her subjugation to norms, the subject creates new, unprecedented forms of behavior, including forms of resistance, and in turn, institutions will have to elaborate new forms and procedures in order to counter them. (In Hacking's vocabulary, psychiatric patients can be described as "interactive kinds," which makes them "moving targets" when it comes to the interpretation of their character and behavior (Hacking 1999 and 2007).

For Foucault, psychiatry, its categories and subjects, are either constructed or cannot exist, which does not mean that he endorses its particular methods, results, and, especially, consequences; on the contrary, they all should be criticized. The subjects (that is, the patients) dealt with in psychiatric practice have a particular kind of objectivity. This reality is thoroughly constructed, but this fact, in the absence of a clear norm of "objectivity," does not reduce the scientific quality of psychiatry as a science. This is the reason 
criticism cannot redirect the mode of truth construction in the terms of an objectivist science, but can only criticize the way in which these scientific objects, which are, in fact, subjects, emerge.

\section{REFERENCES}

Bracken, Pat, and Philip Thomas. 2010. "From Szasz to Foucault: On the Role of Critical Psychiatry." Philosophy, Psychiatry, \& Psychology 17, no. 3: 219-28.

Canguilhem, Georges. 1978. The Normal and the Pathological. Dordrecht: D. Reidel Publishing Company.

Castel, Pierre-Henri. 2009. L'esprit malade: cerveaux, folies, individus. Paris: Ithaque.

Charland, Louis C. 2006. "Moral Nature of the DSM-IV Cluster B Personality Disorders." Journal of Personality Disorders 20, no. 2: 116-25.

- 2008. "A Moral Line in the Sand: Alexander Crichton and Philippe Pinel on the Psychopathology of the Passions." In Fact and Value in Emotion, edited by Louis C. Charland and Peter Zachar, 15-33. Amsterdam: John Benjamins Publishing Company.

_ 2010. "Medical or Moral Kinds? Moving Beyond a False Dichotomy." Philosophy, Psychiatry, \& Psychology 17, no. 2: 101-17.

Foucault, Michel, 1980. "Truth and Power." In Power/Knowledge: Selected Interviews and Other Writings, edited by Colin Gordon, 109-33. New York: Pantheon Books. . 2003. Abnormal: Lectures at the Collège de France, 1974-75. London: Verso.

Gusfield, Joseph R. 1981. The Culture of Public Problems. Chicago: University of Chicago Press.

Hacking, Ian. 1999. The Social Construction of What? Cambridge: Cambridge University Press.

_ 2007. "Kinds of People: Moving Targets." Proceedings of the British Academy, no. $151: 285-318$.

Latour, Bruno. 2013. An Inquiry into Modes of Existence: An Anthropology of the Moderns. Cambridge, MA: Harvard University Press.

Matthews, Eric. 1995. "Moralist or Therapist? Foucault and the Critique of Psychiatry." Philosophy, Psychiatry, and Psychology 2, no. 1: 19-30.

McCallum, David. 2004. Personality and Dangerousness: Genealogies of Antisocial Personality Disorder. Cambridge: Cambridge University Press.

Scheff, Thomas J. 1974. "The Labelling Theory of Mental Illness." American Sociological Review 39, no. 3: 444-52.

Szasz, Thomas. 1974. The Myth of Mental Illness. New York: Harper and Row.

Woolgar, Steve, and Dorothy Pawluch. 1985. "Ontological Gerrymandering: The Anatomy of Social Problems Explanations." Social Problems 32, no. 3: 214-27.

Zachar, Peter, and Nancy Nyquist Potter. 2010. "Personality Disorders: Moral or Medical Kinds-or Both?” Philosophy, Psychiatry, \& Psychology 17, no. 2: 101-17. 
PART FIVE

Critical Psychology and the Epistemology of Psy-Knowledge 



\title{
Neoliberal Governmentality, Austerity, and Psychopolitics
}

\author{
Philip Thomas
}

\section{Introduction}

Recent protests over austerity-related benefit cuts indicate that British society is divided. Government attempts to reduce the number of people on benefits are creating a chasm between rich and poor. The most vulnerable in society, disabled people and those with mental health problems, are paying a high price for the political ideology of neoliberalism, some with their lives. Suicides and deaths are the tip of an iceberg of misery experienced by those who are physically or mentally unfit for work, as the government exercises an increasingly punitive and authoritarian regime against benefit claimants. Vulnerable people are left destitute by sanctions that suspend or end their benefits if they fail to comply with orders to attend "assessments," "training courses," or submit the required number of job applications each week.

It is therefore unsurprising that there has been a resurgence of interest in the work and ideas of the British psychologist Peter Sedgwick (Cresswell and Spandler 2009; Tietze 2015; Cresswell and Spandler 2015). ${ }^{1}$ He is best remembered for his 1982 book Psycho Politics in which he set out a Marxist critique of antipsychiatry. At the heart of his book (Sedgwick 1982) is an argument of contemporary relevance in the face of austerity: that the label "mental illness" has political value because it can be used to make demands on the state for

${ }^{1}$ On June 10, 2015, the conference "Psycho Politics in the Twenty-First Century: Peter Sedgwick and Radical Movements in Mental Health" was held at Liverpool Hope University. 
support for those who experience distress. This should not, however, be taken to mean that Sedgwick supported the biomedical model of mental illness.

In this chapter, I will outline Sedgwick's arguments before setting out briefly the relevant aspects of neoliberalism. Sedgwick was critical of Foucault's (1967) position in Madness and Civilization, but because of Sedgwick's untimely death in 1983, he was unaware of Foucault's later work, especially The Birth of Biopolitics. For this reason I will examine recent developments in government policy towards persons on benefits, and then consider the relevance of both Sedgwick's and Foucault's work for those resisting neoliberal austerity. In particular, my focus at the end will be on the work of the radical survivor group called Recovery in the Bin.

\section{Psychopolitics}

Sedgwick argued that antipsychiatry was problematic for a number of reasons. Szasz (1974) relied on a fallacious distinction between what he saw as a purely biological, value-free world of physical illness, and a value-laden world of mental illness. Another problem concerns Laing's (1959) critique of positivism in psychiatry, which questions the status of psychiatry as a medical (and thus scientific) discipline. Sedgwick argued that there is an inconsistency in Laingian arguments that deny the applicability of the methods of natural science in psychiatry, while claiming that there is still a role for medicine in psychiatry. Finally, the anti-psychiatrists' position was cynical. They opposed positivistic psychiatry, but did so from such widely different perspectives that it was impossible to see a constructive way forward in terms of developing alternatives for people who experience distress. This leads to a position of nihilism: "And the cynic cannot really be a critic; the radical who is only a radical nihilist, or a radical tragedian, is for most practical purposes the most adamant of conservatives" (Sedgwick 1982, 42).

Instead, Sedgwick proposed a unitary perspective on physical and mental illness to make the values of both explicit. A unitary theory of illness stands above the moral and conceptual crisis that antipsychiatry forces upon psychiatry-that psychiatric disorders are brain disorders (in which case psychiatrists have a legitimate role as doctors), or denying they are illnesses (in which case the role of psychiatrists is a moral one, akin to the priest or policeman).

Sedgwick was critical of what he regarded as Foucault's (1967) arbitrary and occasionally inaccurate historical analysis in Madness and Civilization. 
He also criticized him for being over-concerned with doctors', not patients' perspectives (Sedgwick 1982, 137). But the most serious accusation he leveled against Foucault was that he failed to set his analysis against what he called, ". .. the rise and fall of class relationships in different modes of production, or contrasting political systems" (138). He believed that Foucault viewed psychiatry apart from the social conditions in which it operated. This analysis of psychiatry, argued Sedgwick, was couched in terms of medical and scientific insights in isolation from the social and political realities that shaped them, particularly those of class and production. Consequently it is not possible to consider psychiatry as a practice whose purpose is to "improve the implements of production."

\section{Neoliberalism and the Shrinking State}

Since the publication of Psycho Politics, the political and economic landscape has been transformed by neoliberalism. There is much debate about the origins and history of neoliberalism, but this is beyond my scope. Here I will set out some of the key consequences of the ideology as far as those on benefits are concerned. Harvey defines neoliberalism as: "the theory of political economic practices that proposes that human well-being can best be advanced by liberating individual entrepreneurial freedoms and skills within an institutional framework characterised by strong private property rights, free markets, and free trade" (Harvey 2005, 1-2). An important consequence of this is a reduction in the power of the state, which is limited to the creation of institutional frameworks necessary to support free markets, and the provision of the legal structures necessary to secure private property rights.

In the UK, the policies of Margaret Thatcher epitomized the value attached to individual freedom in neoliberalism. She slashed welfare spending, weakened the unions, and privatized public utilities and social housing. These changes were driven by her view that "There is no such thing as Society. There are individual men and women, and there are families." ${ }^{2}$ Harvey writes thus of neoliberalism: "All forms of social solidarity [collectivism] were to be dissolved in favour of individualism, private property, personal responsibility, and family values" (Harvey 2005, 23).

2 Margaret Thatcher, Women's Own, October 31, 1987. 
A consequence of this is the view that human beings stand or fall by their personal responsibility for their decisions, actions, and choices. If the origins of personal success or failure are to be understood solely as a consequence of individual liberty, then the great deceit of neoliberalism is that what are assumed to be the consequences of individual choice have nothing to do with the wider social, economic, and political contexts in which that individual is embedded. Thus personal failure is the property of the individual. Poverty arises because the individual has the "wrong" attitude, a "faulty" set of beliefs, or a lack of "positive affect." It has nothing to do with an increasingly unjust society. Neither is it related to personal stories grounded in oppression, racism, and abuse. This idea, that personal failings are the primary determinants of poverty, is at the heart of neoliberalism. The notion of individual freedom lies at the heart of neoliberal ideology (hence "liberal"). It conflicts with Sedgwick's view that we share a collective responsibility for each other. At the same time, the notion of individual freedom is open to a Foucauldian analysis of power and governmentality.

\section{Power and Governmentality}

Foucault's insights into the nature of power are arguably one of his most important contributions to contemporary thought. He argued that political theories such as Marxism or Liberalism see power largely in negative terms (Bracken and Thomas 2010); power suppresses, limits, and silences. However, in his later work he argued that power could be positive and productive as well as negative and oppressive.

Foucault had a complex relationship with Marxism. He was, for a time, a member of the French Communist Party, but he left in 1953 never to rejoin. Olssen (2004) points out that although he was often critical of Marxism, there are similarities between Marx and Foucault's analysis of power in social relationships, but there are important differences. Foucault rejected historical materialism because it originated in what, in his view, was the problematic tradition of the Enlightenment. Where classical Marxism saw power relationships between subjects in terms of class struggle between the proletariat and capital, Foucault's key insight was that any analysis of power had to engage with the way that power relationships constituted the subjects involved in them.

Foucault (1982) did not completely disavow Marxist analyses of power, but he denied the claim that they are foundational. He argued that the mecha- 
nisms of subjection, while not independent of Marxist analyses, are not determined by them. He was also deeply critical of the form of individualism found in contemporary neoliberal societies. In The Birth of Biopolitics (Foucault 2008, 186), he points out that the function of governmentality in neoliberalism is to "conduct the conduct of men." He is concerned here with how the conduct of economic subjects, or homo aeconomicus, is governed in civil society: "civil society is the concrete ensemble within which these ideal points, economic men, must be placed so that they can be appropriately managed. So, homo aeconomicus and civil society belong to the same ensemble of the technology of liberal governmentality" $(2008,296)$. Rose $(1990,5)$ argues that governmentality is central to modern forms of political rationality, because it defines the tasks of government in terms of the supervision and maximization of the forces of society, through the "... regulation of the processes proper to the population, the laws that modulate its wealth, health, longevity, and its capacity to wage wars and engage in labour...."

Psychology plays a central role in neoliberal governmentality. In Governing the Soul, Rose deals with the forms of governmentality necessary to regulate and control the employed to maximize profit. However, the banking crisis of 2008 resulted in new priorities in the governmental function of psychology and psychotherapy, with the focus shifting from the employed to the unemployed.

Friedli and Stearn (2015) have shown how clinical psychology and therapy have become incorporated into government action directed against benefit claimants. A range of psychological "assessments" and "interventions" now control the lives of hundreds of thousands of citizens with disabilities and mental health problems, through the use of what they call psychocompulsion, the imposition of psychological explanations for an individual's unemployment. The justification for this is the neoliberal view that unemployment originates in "faulty" beliefs about the reasons the person is unemployed. These give rise to "faulty" attitudes and behaviors, such as "benefit dependency." Consequently, unemployed people end up on benefits long-term and resist seeking paid employment. The government has introduced assessments to identify these "faulty" beliefs, and programs to "rectify" them through "therapy." These psychological interventions are forced on benefit claimants. If they refuse to comply, their benefits are suspended or stopped.

Psychocompulsion draws heavily on the "strengths-based" literature of positive psychology, especially notions of confidence, resilience, optimism, and self-efficacy. Positive psychology is suspicious of "depth" psychologies that encourage the person to reflect inwardly on feelings, beliefs, and past 
experiences that originate in trauma and adversity (Binkley 2011). Instead, it encourages the person to take responsibility for his or her own feelings, dwelling particularly on the importance of finding "happiness." It rejects attempts to understand the person's problems in terms of past or current adversity, and instead focuses on future action. It renounces the main object of therapeutic work-the painful exploration of difficult emotional states by talking about them.

Friedli and Stearn point out that this is an attempt by the state to govern and manage disabled subjectivities, so that ". . . liberal subjects' capabilities, inclinations, and desires are in accord with values and expectations that are identified as already given by a civil society centred on the labour market" (Friedli and Stearn 2015, 42). This focus on the individual works against the possibility of group solidarity and collective action on the part of those on benefits.

\section{Resistance and Alliances}

What is the way forward? Sedgwick argues that this must be through a transformation of the social, political, and economic structures of late capitalism. There are too many aspects to consider here, but a key element is a radical political program involving service users, mental health professionals, unions, and community activists. Foucault's analysis of power supports this, especially the role of service users in resisting austerity. He argued that political struggles around identity are primarily directed at the analysis of power, and furthermore, they are "immediate" in the sense that those involved in the struggle are those who are most directly affected by the source of their oppression:

In such struggles people criticize instances of power which are the closest to them, those which exercise their action on individuals. They do not look for the "chief enemy," but for the immediate enemy. Nor do they expect to find a solution to their problem at a future date (that is, liberations, revolutions, end of class struggle). In comparison with a theoretical scale of explanations or a revolutionary order which polarizes the historian, they are anarchistic struggles. (Foucault 1982, 211, emphasis added) 
The work of the radical survivor group Recovery in the Bin exemplifies this. ${ }^{3}$ The group bitterly opposes the colonization of "recovery" by mental health services, commissioners, and policy makers. The group's eighteen key principles argue that this colonization is evidence that neoliberalism and capitalism are in crisis (RITB 2015, 1). Recovery is beyond the ability of many who live in intolerable social and economic circumstances, in appalling conditions of poor housing, poverty, and daily experiences of stigma, racism, and sexism.

Yet despite this, they face coercion and unreasonable demands from Department for Work and Pensions staff to "recover." Recovery in the Bin uses the term "UnRecovered" as a form of self-definition to contrast it politically with "Recovered." The techniques of psychocompulsion described by Friedli and Stearn (2015) based in positive psychology are "being used to pacify patients and stifle collective dissent" (RITB 2015, 1, emphasis in the original). The group argues that autonomy and self-determination can only be achieved through collective action rather than through individualistic striving. They demand instead a social model of madness and distress in the context of the wider class struggle, arguing both from personal experience and evidence that capitalism and social inequality are bad for mental health. The challenge facing this group and their allies in forging alliances of resistance are formidable, but on September 12, 2015, the direction of the political wind in the UK shifted to a more favorable quarter with the election of a Labour Party leader opposed to austerity. These are powerful reasons to continue the struggle.

\section{REFERENCES}

Binkley, Sam. 2011. "Psychological Life as Enterprise: Social Practice and the Government of Neo-Liberal Interiority." History of the Human Sciences 24, no 3: 83-102.

Bracken, Pat, and Philip Thomas. 2010. "From Szasz to Foucault: On the Role of Critical Psychiatry." Philosophy, Psychiatry, and Psychology 17, no. 3: 219-28.

Cresswell, Mark, and Helen Spandler. 2009. "Psychopolitics: Peter Sedgwick's Legacy for the Politics of Mental Health." Social Theory and Health 7, no. 2: 129-47.

3 Starting out as a facebook group, RITB was formed in January 2015, and by September, its facebook membership had grown to just under 500 . The social media group is not active anymore, but the group's website is https://recoveryinthebin.org (last accessed May 8, 2019). 
2015. "Psychopolitics Today: A Response to Tad Tietze." Critical and Radical Social Work 3, no. 1: 119-24.

Foucault, Michel. 1967. Madness and Civilization: A History of Insanity in the Age of Reason. London: Tavistock.

_ 1982. "Afterword." In Michel Foucault: Beyond Structuralism and Hermeneutics, edited by Hubert Dreyfus and Paul Rabinow, 208-16. New York: Harvester Wheatsheaf.

- 2008. The Birth of Biopolitics: Lectures at the College de France, 1978-1979. Edited by Michel Senellart. Translated by Graham Burchell. Basingstoke: Palgrave Macmillan.

Friedli, Lynne, and Robert Stearn. 2015. "Positive Affect as Coercive Strategy: Conditionality, Activation, and the Role of Psychology in UK Government Workfare Programmes." Medical Humanities 41, no. 1: 40-47.

Harvey, David. 2005. A Brief History of Neoliberalism. Oxford: Oxford University Press.

Kushner, Barry, and Saville Kushner. 2013. Who Needs the Cuts? Myths of the Economic Crisis. London: Hesperus Press.

Laing, Ronald D. 1959. The Divided Self. London: Tavistock.

Moth, Rich, Joe Greener, and Trish Stoll. 2015. "Crisis and Resistance in Mental Health Services in England." Critical and Radical Social Work 3, no. 1: 89-102.

Olssen, Mark. 2004. "Foucault and Marxism: Rewriting the Theory of Historical Materialism.” Policy Futures in Education 2, no. 3-4: 454-82.

Recovery in the Bin. 2015. "Manifesto." Available online at https://recoveryinthebin. org/ritbkeyprinciples/ (last accessed May 8, 2019).

Rose, Nikolas. 1990. Governing the Soul: The Shaping of the Private Self. London \& New York: Routledge.

Sedgwick, Peter. 1982. Psycho Politics. London: Pluto Press.

Szasz, Thomas. (1961) 1974. The Myth of Mental Illness: Foundations of a Theory of Personal Conduct. New York: Harper Collins.

Tietze, Tad. 2015. "Peter Sedgwick: Mental Health as Radical Politics." Critical and Radical Social Work 3: 103-17. 


\title{
Psycho-Politics and Illness Constructions in the Background of the Trauma-Concept of the DSM-5
}

\author{
Márta Csabai and Orsolya Papp-Zipernovszky
}

\section{Introduction}

Jonathan Gornall, a British journalist, starts his article with the somewhat sensational title "DSM-5: A Fatal Diagnosis?" (published in the British Medical Journal on 22 May, 2013, the day DSM-5 was published) by noting that it is not every day that a medical handbook achieves the same level of success with the general public as a blockbuster novel would (Gornall 2013). This is exactly what happened with DSM-5: it had received international attention comparable to the most recent Dan Brown book even before it was published. What are the reasons for the enormous interest in and the extremely heated debates surrounding the new psychiatric nomenclature?

The development of the medical sciences and technologies has brought about the discovery of new illnesses, the establishment of new diagnostic categories, and their re-classification or even elimination. These changes cannot be sufficiently explained on the basis of new biological phenomena or epidemiological patterns. Social factors, economic and political considerations, professional interests, and intellectual trends are also very important in articulating new ideas and concepts. We also have to take into consideration that professionals as well as patients constantly need legitimate, well-defined, and effectively manageable categories of illnesses; insecurity resulting from the acceptance of the limits of medicine may cause frustration for both sides. Usually, there are questions concerning the legitimacy of those categories of illnesses that either lack a clear or specific diagnosis or whose definition is strongly influenced by social and psychological factors. 
This is why mental and psychosomatic illnesses are most likely to fall into this group.

In the period between 1999 and 2012-that is, during the period when the new DSM-5 was in progress-many professionals advanced broad and serious concerns about the "medicalization of normality" (Pickersgill 2013). The critics' main worry was that the DSM-5 would "expand the territory of mental disorder and reduce the ranks of the normal" (Frances 2010, 492). Others raised the issue of the role of the pharmaceutical industry in constructing new disease categories, calling it the "engine of diagnosis" (Jutel 2009) and expanding medicalization to "pharmaceuticalization." As Pickersgill (2013) suggested, criticisms of the DSM should be positioned within larger critiques of psychiatry and biomedicine and treated as debates responsible for re-energizing the longstanding discussions and conflicts around the utility and validity of constructed disease categories.

\section{The Role of "Deficit-Discourses" in Constructing Diagnoses}

The problem of medical diagnostics extends far beyond issues of normality and pathology and relates to another question of ontological significance. Mostly due to the successes of psychoanalysis in the first half of the twentieth century and its influence on culture and the humanities (and the retreat of religious practice), psychological discourse has become one of the main linguistic vehicles of self-interpretation in our times. According to Kenneth Gergen (1994), this can be regarded as a "deficit-discourse" characterized by thematizing the main events of our life in the context of emotional problems. We shape the meanings of mental health along with the definitions provided by health professionals. Philip Cushman (1995) makes the point even more sharply: he thinks that nowadays people like to validate their self through the authority of science, and science reveals the self as in constant need of diagnosis and treatment. Nikolas Rose (1985) calls this the "psy-complex" of our age. Critics note that the DSM-5 also wants to fulfill the expectations described above by attempting to medicalize more and more general human life circumstances or problems, for instance grief (Strong 2012). A number of professional and non-profit organizations have expressed their disagreement over this, and critical voices appeared in highly acclaimed journals such as Nature (Ledford 2011) and Scientific American (Jabr 2012). Thomas R. Insel, director of the US National Institute of Mental Health, shared the following 
critique in his regular "Director's Blog" series a few days before the publication of the DSM-5 in 2013:

The strength of each of the editions of DSM has been "reliability." ... The weakness is its lack of validity. Unlike our definitions of ischemic heart disease, lymphoma, or AIDS, the DSM diagnoses are based on consensus about clusters of clinical symptoms, not any objective laboratory measure. In the rest of medicine, this would be equivalent to creating diagnostic systems based on the nature of chest pain or the quality of fever. (Insel 2013)

This quote reflects the disputes about psychiatric diagnosis and definitions of "normality" in general and resurrects the atmosphere of the debates in the 1960s and 1970s, when anti-psychiatry representatives clashed with psychiatric orthodoxy. The anti-psychiatrist school also claimed that the concept of mental illness was in fact a myth, an attempt to conceal the troubles and tensions in society (Szasz 1974). Similar thoughts were expressed by Michel Foucault, according to whom psychiatric diagnoses were simply evaluative categories that secured the legitimacy of the power of medicine based on the mechanisms of "biopolitics" (Foucault [1963] 1973). According to another critical approach, psychological disturbances are simply those patterns of behavior or phenomena, which are treated by professionals ad absurdum, and constructed by them through the use of diagnostic systems (Hoffman 2001). Patients then get a chance to have their story re-written through the interpretive framework of the very same professional. A possible conclusion is that professional images of "normality" or healthy functioning are submerged in "deficit discourses" along with cultural ideals relating to individuals, and these are often linked to political ideologies.

Certainly, these directions are not typical in mainstream psychiatry. According to the definition of the DSM-5, the current official position of the psychiatric profession, we consider mental disorder to be culturally deviant (unexpected) reactions to a significant stress or loss:

A mental disorder is a syndrome characterized by clinically significant disturbance in an individual's cognition, emotion regulation, or behavior that reflects a dysfunction in the psychological, biological, or developmental processes underlying mental functioning. Mental disorders are usually associated with significant distress in social, oc- 
cupational, or other important activities. An expectable or culturally approved response to a common stressor or loss, such as the death of a loved one, is not a mental disorder. Socially deviant behavior (e.g., political, religious, or sexual) and conflicts that are primarily between the individual and society are not mental disorders unless the deviance or conflict results from a dysfunction in the individual, as described above. (A.P.A 2013)

The definition can be questioned from a number of perspectives. It is hard to define what we regard as "significant" stress and "unexpected" reactions. Furthermore, as raised by some critics, why is it necessary to have a new definition in the DSM, when the phenomenon itself, mental disorder, has not changed? (Maisel 2013). Or if it has changed because the related concept was altered, then this leaves room for significant criticism, especially if we also consider the fact that the classification systems introduced prior to 1980 included no definition of any kind and that categories of pathological mental functioning were purely based on their names.

The constantly increasing diagnostic repertoire, the renaming or new nomenclature, can also have an effect on the emergence of symptoms and disturbances. Some authors think that this always corresponds to society's ethnopsychological (unconscious) assumptions regarding illnesses and deviation (Gaines 1992). The mainstream, including the authors of DSM, evaluates the increase of diagnoses along a linear interpretation of the history of medicine, representing the development of society and science. This is reinforced by the opinion of the designers of newer and newer diagnostic systems who think that their interpretation is imbued with "higher scientific value" than the ones before. The mainstream exhibits a kind of re-medicalization tendency, where biological and statistical approaches are dominant, and the psychodynamic approach and psychotherapeutic activity are significantly pushed into the background. The American Psychiatric Association's (APA) explicit intention is to use several evidence-based criteria such as clinical utility, reliability, descriptive validity, and psychometric performance to ensure that a condition is appropriately included as a disorder in the DSM (Fisher and Shell 2013). Nevertheless, due to the strong medicalization, the critical approaches that underline the role of discursivity in the establishment of diagnoses and the role of narrative elements in therapeutic work have also become stronger as a kind of a counter-effect (Frank 1995; Charon 2008). 


\section{The Struggle with Uncertainty: The Great Turn of the DSM into "Diagnostic Psychiatry"}

Allan Horwitz (2002) remarks that the gradual shift to the biological perspective from the 1970s on-and the change reflected by the transformations of the nomenclature mostly in the DSM-III-was made necessary by the fact that psychodynamic approaches have failed to match contemporary expectations raised by scientific research and the process of verification. Therefore, people responsible for classification did not feel comfortable with the validity and reliability of these diagnoses. From this point on, medicine has turned away from the case studies that played such a significant role in Freud's work, causing a devastating blow to the dominant position of psychoanalysis, as this new approach used only "objective facts." Scientific psychiatry was no longer able to make use of psychodynamic notions based on analytic theories. The era of the category of neurotic disorders traditionally based on psychodynamic interpretation is a significant factor, too. While psychoanalysts were pushed into the background, in psychiatric institutions and on the editorial committee of the DSM, hysteria gradually disappeared from the official catalogue.

Psychiatrists researching the revision of the DSM-II held a session at Washington University, Saint Louis in 1974. Their main aim was to replace the "hard to adopt" process model of mental disturbances with an approach based on categories. They thought that this would enable them to diagnose each mental disorder reliably and to study them empirically in various populations. Allan Horwitz (2002) termed the era after the publication of the DSM-III "diagnostic psychiatry." According to him, this was useful in the case of psychotic illnesses and bipolar disorders-for instance, depression and mania-but it made the understanding and treatment of all other mental and behavioral problems more difficult. The new approach of the DSM-III was to replace the phenomenological approach with decidedly neutral, biological discourse. This caused severe problems in the interpretation of the leading illnesses in psychoanalysis: neurotic illnesses and hysteria, because, in the case of the former, emphasis was on the various forms of the expression of suffering. The changes in the general relation of medicine to the body and illness can be followed by tracking down the changes in the diagnosis and symptoms of hysteria as well (Gilman 1993). Fuelling attempts to diminish previous psychoanalytic diagnoses from the DSM-III, we also assume the desire for certainty, which subconsciously guides the authors of the various editions of 
DSM: only "evidence-based" illness can be "real" illness. They all hope that by proving the "objective" existence or non-existence of a disorder, they can eliminate the uncertainty and finally gain control over mental illnesses that have caused frustration in science and therapy for thousands of years.

\section{Femininity and Illness: Diagnostic Stigmatization as a Way of Suppression}

Describing the hysterical (after DSM-III: "histrionic," "somatizing," "dissociative," etc.) character traits, most authors mention the high correlation frequency with "feminine" traits. Equating hysteria (just as somatization) and femininity has been debated many times in the history of the illness. Indeed, most authors traditionally described hysterical persons as "feminine," or in the case of men, as "passive homosexuals." Paul Chodoff and Henry Lyons have stated (1958) that "hysterical" symptoms and personality traits can exist independently of each other, and have established seven personality traits. According to this list, a hysterical personality is characterized by uncertainty, egocentric but unstable affectivity, a search for dramatic attention, sex-orientation which is provocative but frigid, dependency in interpersonal situations, and demanding behavior.

However, we have to mention that Chodoff and Lyons noted already in 1958, that is, before the emergence of second-wave feminist movements, that hysteria could not be interpreted as a "caricature of femininity" on a biological basis, but rather as the distorting effect of society, which is dominated by men. We could add that professionals could have played a significant role in shaping the "caricature," a supposition supported excellently by the now classic and still very topical research by Broverman et al. (1970). They asked psychologists, psychiatrists, and social workers to characterize a healthy man, a healthy woman, and a healthy person whose gender was not revealed. The participants' answers indicated that the characters of healthy "person" and "man" resembled each other to a higher degree. According to this assessment, the healthy person (man) is less submissive, independent, less impressionable, more competitive, more aggressive, less emotional, and looks after his appearance to a lesser degree. Of course, social roles of men and women have changed a lot since that research took place forty years ago. From this list, a couple of personality traits would no longer ring true. Nevertheless, gender stereotypes have survived (Ussher 1991; Foss and Sundby 2003). As the statistical data relating to somatization proves, more than 90 percent of patients are women; this is partly 
due to the fact that complaining, showing weakness, and openly admitting to having an illness is regarded as "feminine," and in some cases is a "hysterical" personality trait in both ordinary and professional representations even today (Creed and Barsky 2004). It should also be noted that the diagnosis itself could serve as the trigger of a trauma. As Widiger (2000, 6-7) has put it: "Even if there is no bias in the definitions or in diagnostic criteria, there may be a bias in the way they are commonly applied," and "clinicians must be cautious and self-critical, especially when diagnosing histrionic and dependent personality in women or narcissistic and obsessive-compulsive personality in men."

As a positive change, we welcome the omission of the categories of somatization disorder, hypochondriasis, pain disorder, and undifferentiated somatoform disorder from DSM-5, which was the offspring of the earlier hysteria diagnosis, which often reflected the gender stereotypes above. Instead of these, the category "Somatic Symptom Disorder" was introduced. That has led to a major debate in the professional literature. Some writers have supported the idea that this would lead to a larger danger than the one we pointed out above relating to the issue of femininity. The most influential of these was the writing of Allen Frances, the Chair of APA DSM-IV Task Force (Frances 2013). According to his view published in the British Medical Journal and other periodicals, the new diagnosis "risks mislabeling many people as mentally ill." He argues that the DSM-5 defines somatic symptom disorder too vaguely. One bodily symptom that is distressing or disruptive from the viewpoint of the everyday functions of life present for at least six months is enough for a diagnosis, as is one which produces one of the following symptoms: disproportionate thoughts about the seriousness of the symptom(s); a persistently high level of anxiety about the symptom(s); or excessive time and energy spent on health concerns. Frances thinks that, based on these vague criteria, millions of people can be labeled as mentally ill and thus be stigmatized. Women can be particularly subject to this since they are more inclined to show somatizing tendencies like the emotionally colored presentation of their symptoms and catastrophization. In his article, Frances quotes Thomas Szasz (1997): "In the days of the Malleus, if a physician could find no evidence of natural illness, he was expected to find evidence of witchcraft: today, if he cannot diagnose organic illness, he is expected to diagnose mental illness." Have we returned to an inquiry of the "reality" of symptoms? This dilemma in the history of psychoanalysis and DSM is best illustrated by the diagnosis, which we may regard the heir of the earlier hysteria concepts, classified in 1980 as post-traumatic stress disorder (PTSD). 


\section{"Real" and "Imagined" Traumas}

The diagnosis of post-traumatic stress disorder (PTSD) was established following demands of Vietnam War veterans to the APA (Showalter 1997). That was a significant event in the history of the DSM, as civil society, e.g., users of psychiatric-psychotherapeutic services, directly interfered in shaping the nomenclature. Vietnam veterans wanted to receive official support and draw attention to their condition, which was not at all easy. It was met with sharp resistance by APA, despite the fact that the enduring effects of war traumas were long known in medicine and psychology. "War neurosis" became well known around the end of World War I. Already at this stage, Freud and his followers associated it with the consequences of other traumas and the diagnosis of hysteria. In his work, A General Introduction to Psychoanalysis Freud describes it:

The closest analogies to these conditions of our neurotics are furnished by the types of sickness which the war has just now made so frequentthe so-called traumatic neuroses. Even before the war there were such cases after railroad collisions and other frightful occurrences which endangered life. The traumatic neuroses are, fundamentally, not the same as the spontaneous neuroses which we have been analyzing and treating; moreover, we have not yet succeeded in bringing them within our hypotheses... The traumatic neuroses show clear indications that they are grounded in a fixation upon the moment of the traumatic disaster. In their dreams, these patients regularly live over the traumatic situation; where there are attacks of an hysterical type, which permit of an analysis, we learn that the attack approximates a complete transposition into this situation. It is as if these patients had not yet gotten through with the traumatic situation, as if it were actually before them as a task which was not yet mastered. We take this view of the matter in all seriousness; it shows the way to an economic view of psychic occurrences. (Freud 1920, 237)

1 Prior to Freud's description, a few rather metaphoric terms had already been used to name the set of PTSD symptoms: "soldier's heart" during the American Civil War era; "railway spine" in the late ninteenth century ran parallel with the war neurosis "shell shock" and "combat fatigue" during World War II (Fisher and Schell 2013). 
Indeed, it is striking that the definition of PTSD in DSM-III resembles the Freudian description:

A. The person has experienced an event that is outside the range of usual human experience and one that would be markedly distressing to almost anyone.

B. The traumatic event is persistently re-experienced in at least one of the following ways:

1. recurrent and intrusive, distressing recollections of the event (in young children, repetitive play in which themes or aspects of the trauma are expressed);

2. recurrent distressing dreams of the event;

3. sudden acting or feeling as if the traumatic event were recurring (including "flashback" or dissociative episodes, whether or not intoxicated);

4. intense psychological distress at exposure to events that symbolize or resemble an aspect of the traumatic event, including anniversaries.

We do not have precise records regarding the reason as to why the APA initially opposed the demands of the Vietnam War veterans (that they receive some kind of a medical treatment and explanation for their post-war symptoms), but it would not be surprising to find that there was a conscious or unconscious rejection of an attempt to regenerate the conceptual framework of Freud. Nevertheless, these veterans eventually received public support and also relied on another very effective argument: they cited the example of Holocaust survivors. By this time, the long-standing, inter-generational consequences of war trauma had been discovered in those circles. The diagnosis of PTSD, post-traumatic stress disorder, appeared in the DSM-III published in 1980 (paradoxically exactly in the edition that was "purified" from psychoanalytic interpretations). It has since become the most frequently applied diagnosis in the world, applied to a wide range of social and private traumatization (Schiraldi 2009). Sadly, Vietnam veterans hardly benefited from the diagnosis and the therapy they fought for, as most of them rarely ever took advantage of the therapeutic services offered (Showalter 1997). The underlying reasons for this were that they would be stigmatized, labeled mentally weak, and would lose their sense of masculinity. They did not trust psychotherapy because they did not know how it worked and what effect it had. In fact, they were not fighting for a diagnosis, but for help, for (psychic) support, to be able 
to get rid of the symptoms. Therefore, a number of analysts asked whether it was necessary to diagnose the victims of terror in order to help them.

The case of the Vietnam veterans shows that if people want professional help, first they must show that they are (very) ill. It is also remarkable that Gulf War veterans also rejected the PTSD diagnosis (Showalter 1997). In their case, there were a number of physical symptoms in addition to their mental ones, and the latter did not fit under the category of PTSD. The veterans desperately fought with the U.S. administration when they tried to prove that their symptoms were caused by pyrodostigmin, which was deployed in the war. Hundreds of newspaper articles in the British, American, and world press-many of them only gossip or rumor-described this situation in the nineties. Veterans' symptoms were interpreted by many as having been caused by media hype. This is how the phrase "Gulf War Syndrome" was coined. The background of the symptoms is yet to be elucidated while the veterans continue to spend their money on new medical tests and lawsuits instead of admitting that their symptoms were, at least partially, caused by the lasting trauma of war.

The underlying stigmatizing effects of a PTSD diagnosis are well illustrated by Fisher and Schell (2013). The APA responded to the request submitted by senior U.S. Army leadership in 2011 by suggesting a change of the term "disorder" in PTSD to "injury." The main reasoning behind the request was that "disorder" is stigmatizing and allows U.S. military service members exhibiting these symptoms to look for professional help. Psychiatric diagnoses in DSM serve the needs of the community of "helpers," "researchers," and "educators" in forming a shared basis of knowledge for communication rather than the needs of the patients in reducing their suffering and maintaining their everyday activities. Of course, these two sets of needs overlap in some ways, for example, the recognition of PTSD "as a condition to be treated, rather than as cowardice or malingering" (Fisher and Schell 2013, 4). The shared intention of clinicians and patients could be to identify a set of symptoms as unhealthy in a way that can benefit from professional evaluation and financed treatment. The authors see real disadvantages of PTSD diagnosis outside the psychiatric community, using it as an accusatory and stigmatizing social category in court, e.g., when determining eligibility for security clearances, in law, or in the workplace, judging deployment and one's career trajectory. In general, mental illness is an undesirable label that devalues or dehumanizes those who have it, depicting them as more dangerous or incapable of handling their own affairs. In 2008, RAND surveyed military service mem- 
bers about their inhibitions concerning psychological treatment. The harmful effect on one's career was regarded as the most important factor among respondents (44 percent). This is well illustrated by the phenomena that the U.S. Army has already informally deleted "disorder" from PTSD on certain documents and websites, and uses the term "post-traumatic stress" or "combat and operational stress reaction."

But how did PTSD become the most utilized diagnosis if veterans still reject it? This is especially interesting considering the fact that, according to research, only a minority of survivors of mass accidents, wars, and other catastrophes develop these symptoms (Carll 2007). There must be social and political reasons in the background for such a diagnosis. From the 1970s onwards, issues of abuse against women and children have entered the public discourse due to the activisms of feminist and human rights movements. Following the establishment of the PTSD diagnosis, the number of patients grew gradually, mostly through the inclusion of abused women. As a consequence, the notion of trauma expanded significantly, including not only exceptional stress situations and catastrophes, but also the consequences of emotional wounds inflicted by everyday life. Caruth (1995) points out that trauma is caused by psychic content that cannot be symbolized and described with words and thus returns in direct forms. The unsymbolizable verbal nature can be a reason why modern media intervened to find visual and verbal expressions for each kind of trauma. Trauma is basically transmitted and channeled by the media, which makes global and local traumatic events directly perceivable, "normal," and overall present in the backgrounds of our lives. This turn inevitably adds a socio-political dimension to the understanding of trauma, as the definition of Kirmayer, Lemelson, and Barad $(2007,1)$ illustrates: "Trauma can be seen at once as a socio-political event, a psycho-physiological process, a physical and emotional experience, and a narrative theme in explanations of individual and social suffering." Our view of psychic trauma as both cause and consequence has become an inherent part of present-day culture.

\section{The Re-Construction of Trauma in the DSM-5}

The debate about the concept of trauma intensified again in the 1980s. Since then, an enormous number of psychological and psychiatric publications on the subject have seen the light of day. In addition, aspects of human rights and criminal law were also addressed in these debates. These were mostly centered 
around "memory therapies" in the United States, during which a number of psychotherapists tried to rehabilitate Freudian seduction theory, unveiling abusive childhood memories of the patients, which then serve as evidence in subsequent lawsuits (Pendergrast 1995; Masson 1998). The dilemma, seemingly irresolvable, was caused by the fact that it is extremely difficult to measure the weight of a trauma suffered by an individual or a group. Therefore, it is practically impossible to evaluate whether the reaction to a given stressor (or trauma) should be considered pathological or not without finding scapegoats. We should address the question whether we need to differentiate between traumatization that happened in reality and traumatization taking place in the imagination of the individual, as the damaging consequences are often similarly grave, and maybe even greater in the case of the latter.

The criteria of PTSD in DSM-5 significantly differ from earlier ones. The most important change from our viewpoint is that it more explicitly defines what is regarded as a traumatizing event and omits the earlier criteria of "subjective reaction." This way, the space to manoeuver in subjective evaluations of individuals became more limited. The age for the diagnosis was extended, and a separate criterion was worked out for children under six years of age. According to critics, this points towards the potential of medicalizing socialization at a very early age, which undoubtedly could have harmful consequences for the development of the individual (Rosen et al. 2008; D'Andrea et al. 2012).

Since a number of debates accompanied the issue of the "reality of the trauma" from Freud to the present day, the DSM-5 also provides a more precise definition of what is regarded a traumatic stressor (suffering the trauma directly or as a witness are considered the same in this respect). Nevertheless, it views physical trauma as the primary stressor. Emotional or verbal abuse, harassment, non-physical sexual harassment, and other potentially traumatizing factors, mostly affecting women, are not really emphasized. Again, we hear the echo of the debates around Freud's seduction theory in the voices claiming that sexism, the objectification of women's bodies, as well as the further legal and other inequalities between women and men could also be traumatic stressors and should find a place on the list of triggers of PTSD in the DSM (Lazaroff 2006). This problem was presented in a special light since new approaches in psychology, psychoanalysis, and the humanities have appeared in discussions about the relationship of historic truth and narrative truth as an especially significant question (Spence 1982; Caruth 1996). This indeed puts strong stress on questions about post-traumatic stress disorder as well as a number of other types of emotional suffering: how, by what methods, and from what perspective 
can the various forms of expression of psychic functioning be classified? Where do the facts end and where do opinions about them begin?

When we discuss illness as a social construct, usually we refer to non-biological factors-beliefs, economic relations, or social institutions-that determine the folk and scientific concepts of illnesses. To demonstrate the validity of social constructs, analysts usually choose an illness that evokes strong reactions. That could refer to the stigmatization of the population affected by that illness (e.g., TB, syphilis, AIDS); the debatable nature of the somatization base and issues of individual responsibility that arise (e.g., psychiatric illnesses, alcoholism, psychosomatic diagnoses); and the frustration raised by the illness or the threat it poses (e.g., different forms of cancer). There are well known analyses (e.g., Sontag 1988) that show the role of social constructs and their influence on professional and popular discourse and also that illnesses possess an especially strong metaphoric power (pest, syphilis, TB, epilepsy, cancer, AIDS).

The related social constructivist, critical psychological, and anthropological literature argues that eradicating and dissecting certain diagnoses while further pathologizing everyday forms of behavior only serves to legitimize the authority of (medical) science (Kutchins and Kirk 2003). However, this reductionist standpoint has to be modified. Changes of diagnoses and symptoms certainly function as a mirror of other important social tendencies, like changes in the knowledge related to the body, discourse about particular illnesses, and the transformation of gender roles (Wenegrat 2001). As Callard (2014) proposed, those who try to use the indeterminate, uncertain nature of the diagnostic classification to support their own views also try to gain power over the discursive space around contemporary issues on the uncertain status of the body in the context of health and illness. However, attention cannot be drawn only to one-dimensional accounts of diagnosis; the rich tradition of philosophical and (psycho)political debates might also support discussion about the changes of diagnoses embedded in very complex clinical, social, cultural, legal, ethical, and psychological configurations.

\section{REFERENCES}

American Psychiatric Association. 2013. Diagnostic and Statistical Manual of Mental Disorders. Fifth Edition (DSM- $\left.5^{\circledR}\right)$. Washington, DC: APA.

Broverman, Inge K., Donald M. Broverman, Frank E. Clarkson, Paul S. Rosenkrantz, and Susan R. Vogel. 1970. "Sex-Role Stereotypes and Clinical Judgments of Mental Health.” Journal of Consulting and Clinical Psychology 34, no. 1: 1-7. 
Carll, Elizabeth K., ed. 2007. Trauma Psychology: Issues in Violence, Disaster, Health, and Illness. Westport: Praeger Publishers.

Caruth, Cathy. 1996. Unclaimed Experience: Trauma, Narrative, and History. Baltimore: Johns Hopkins University Press.

Caruth, Cathy, ed. 1995. Trauma: Explorations in Memory. Baltimore and London: The Johns Hopkins University Press.

Charon, Rita. 2008. Narrative Medicine: Honoring the Stories of Illness. New York: Oxford University Press.

Creed, Francis, and Arthur Barsky. 2004. "A Systematic Review of Somatization Disorder and Hypochondriasis." Journal of Psychosomatic Research 56, no. 4: 391-408.

Cushman, Philip. 1995. Constructing the Self, Constructing America: A Cultural History of Psychotherapy. New York: Perseus.

D'Andrea, Wendy, Julian Ford, Bradley Stolbach, Joseph Spinazzola, and Bessel A. van der Kolk. 2012. "Understanding Interpersonal Trauma in Children: Why We Need a Developmentally Appropriate Trauma Diagnosis.” American Journal of Orthopsychiatry 82, no. 2: 187-200.

Fisher, Michael P., and Terry L. Schell. 2013. “The Role and Importance of the 'D' in PTSD." RAND Corporation, Occasional Paper series. Avalable online at https:// www.rand.org/pubs/occasional_papers/OP389.html.

Foss, Christina, and Johanne Sundby. 2003. "The Construction of the Gendered Patient: Hospital Staff's Attitudes to Female and Male Patients." Patient Education and Counselling 49, no. 1: 45-52.

Foucault, Michel. 1973. The Birth of the Clinic: An Archaeology of Medical Perception. London: Routledge.

Frances, Allen. 2013. "The New Somatic Symptom Disorder in DSM-5 Risks Mislabelling Many People as Mentally Ill.” BMJ 346: 1580. doi: https://doi.org/10.1136/bmj. f1580.

Frank, Arthur W. 1995. The Wounded Storyteller: Body, Illness, and Ethics. Chicago: The University of Chicago Press.

Gaines, Atwood D. 1992. "From DSM-I to III-R: Voices of Self, Mastery, and the Other: A Cultural Constructivist Reading of the US Psychiatric Classification." Social Science and Medicine 35, no. 1:3-24.

Gergen, Kenneth J. 1994. Realities and Relationships: Soundings in Social Construction. Cambridge: Harvard University Press.

Gilman, Sander L., Helen King, Roy Porter, G. S. Rousseau, and Elaine Showalter. 1993. Hysteria beyond Freud. Berkeley: University of California Press.

Gornall, Jonathan. 2013. “DSM-5: A Fatal Diagnosis?” BMJ 346: 3256.

Hoffman, Bjorn. 2001. “The Technological Invention of Disease." Medical Humanities 27, no. 1: 10-19.

Horwitz, Allan V. 2002. Creating Mental Illness. Chicago: University of Chicago Press. Jabr, Ferris. 2012. "Psychiatry's 'Bible' Gets an Overhaul." Scientific American: Mind 23, no. 2: 28-35.

Kirmayer, Laurence J., Robert Lemelson, and Mark Barad. 2007. "Introduction: Trauma in Culture, Brain, and Body." In Understanding Trauma: Integrating Biological, Clininical and Cultural Perspectives, 1-20. Cambridge and New York: Cambridge University Press. 
Kutchins, Herb, and Stuart Kirk. 2003. Making Us Crazy: DSM; The Psychiatric Bible and the Creation of Mental Disorders. New York: The Free Press.

Lazaroff, Ann M. 2006. “The Role of the Diagnostic and Statistical Manual of Mental Disorders in the Maintenance of the Subjugation of Women: Implications for the Training of Future Mental Health Professionals." Forum on Public Policy (online), no. 1. Available online at http://forumonpublicpolicy.com/archive06/lazaroff.pdf.

Ledford, Heidi. 2011. "Mental-Health Guide Accused of Overreach.” Nature 479, no. 731. doi:10.1038/479014a.

Maisel, Eric. 2013. “The New Definition of a Mental Disorder: Is It an Improvement or Another Brazen Attempt to Name a Non-Existing Thing?” Psychology Today, July 23. http://www.psychologytoday.com/blog/rethinking-psychology/201307/thenew-definition-mental-disorder

Masson, Jeffrey. 1998. The Assault on Truth: Freud's Suppression of the Seduction Theory. New York: Pocket Books.

Mitchell, Juliet. 2000. Mad Men and Medusas: Reclaiming Hysteria. New York: Basic Books.

Pendergrast, Mark. 1995. Victims of Memory: Incest Accusations and Shattered Lives. Hinesburg: Upper Access.

Pickersgill, Martyn D. 2013. "Debating DSM-5: Diagnosis and the sociology of critique." Journal of Medical Ethics 40, no. 8: 521-25.

Rosen, Gerald M., Robert L. Spitzer, and Paul R. McHugh. 2008. "Problems with the Post-Traumatic Stress Disorder Diagnosis and Its Future in DSM-V." The British Journal of Psychiatry 192, no. 1:3-4.

Schiraldi, Glenn. 2009. The Post-Traumatic Stress Disorder Sourcebook: A Guide to Healing, Recovery, and Growth. New York: McGraw-Hill.

Showalter, Elaine. 1997. Hystories: Hysterical Epidemics and Modern Culture. London: Picador.

Sontag, Susan. 1988. Illness as Metaphor. New York: Farrar, Straus, and Giroux.

Spence, Donald P. 1982. Narrative Truth and Historical Truth: Meaning and Interpretation in Psychoanalysis. New York: Norton and Co.

Strong, Tom. 2012. "Talking about the DSM-V." Paper presented at the Therapeutic Conversations X Conference, Vancouver, Canada, May 12.

Szasz, Thomas S. 1997. The Manufacture of Madness: A Comparative Study of the Inquisition and the Mental Health Movement. Syracuse University Press.

. 1974. The Myth of Mental Illness: Foundations of a Theory of Personal Conduct. New York: Harper \& Row.

Taylor, F. Kraupl. 1971. "A Logical Analysis of the Medico-Psychological Concept of Disease." Psychological Medicine 1: 356-64.

Ussher, Jane. 1991. Women's Madness: Misogyny or Mental Illness? London: Prentice Hall. Wenegrat, Brant. 2001. Theater of Disorder: Patients, Doctors, and the Construction of Illness. Oxford: Oxford University Press.

Widiger, Thomas A. 2000. "Gender Bias in the Diagnosis of Personality Disorders." The Harvard Mental Health Letter 16, no. 10: 5-7. 



\title{
Is Integration Possible for Psychoanalysis?
}

\author{
Aleksandar Dimitrijević
}

As we encounter psychoanalysis in our education, from the very start, we learn that it is a discipline divided and in constant internal conflict. On one level, by 1950 psychoanalysis was split into several schools of thought that displayed deep animosity toward each other and were unable to collaborate in any substantial way. Probably every major textbook on personality psychology first provides an overview of Freud's theory and then Jung's and Adler's schools that separated from the initial psychoanalytic movement and developed in their own directions (Ellenberger 1970; Ryschlak 1975; see also Makari 2008). The separation of Adler, Stekel, Jung, and other early disciples of Freud resulted in them forming new psychotherapeutical procedures, educational institutes, and even movements that made the refutation of Freud's theory one of their central goals. At the same time, Freud and the second wave of his disciples tried to prove that, for instance, Jung was a mystic (Bair 2003) or that Ferenczi was psychotic (Bonomi 1999), which resembles political campaigning more than scientific refutation. As time went on, these different schools did not move any closer, and one can even claim that differences are now so big that most members of the various schools of psychotherapy that grew out of The Interpretation of Dreams do not follow the others' work. Worse still, their languages have become so different that they understand each other less and less.

These differences are becoming increasingly larger among various versions of psychoanalysis as well. Most often they do not come from their mem- 
bers' devotion to different research topics, clinical methodology, or technological devices they have at their disposal. The most frequent reason for this situation is to be found in the social structure of the psychoanalytic world. (One can only wonder why we still do not have a study of psychoanalytic institutes methodologically similar to Erving Goffman's [1961] studies of asylums.) I believe that we can get a glimpse of these different structures if we analyze the language used in constructing this social world: we talk of "the early schisms" and "heresies" (Bergmann 2004, 5), as if psychoanalysis were a sort of church or religious cult; there are "deviations from Freud's teachings," as if his papers were a holy book and not a source of testable hypotheses; or, as recently as 2006, Hanna Segal $(2006,289)$ claimed that the Freud/Klein/Bion model is a search for truth, while the Independents (specifically Ferenczi, Bálint, Winnicott, and Kohut) "invite the patient to live in a lie."

On another level, psychoanalysis may easily be the only scientific discipline plagued by the problem of dissidence-otherwise a political phenomenon that appears in totalitarian societies. It all began with the view of psychoanalysis more as Freud's creation and less as a method for the scientific research of mental phenomena. The "Secret Ring" of Freud's closest collaborators was formed with the aim of protecting "real psychoanalysis," and for almost fifteen years, the seven of them (including Freud himself) sent out circular letters to each other and dealt with the politics of "the Master's teaching" as best they could, deciding, en route, who should be ostracized-until, of course, their personal antagonisms grew too strong and two of them were treated as dissidents (Grosskurth 1991). Unfortunately, more recent models are not very different. Many of the most important psychoanalytic societies and institutes have dissolved, and many charismatic individuals have created their own schools, centers, periodicals, etc. At one moment, there were thirtyseven different psychoanalytic institutes in Manhattan alone (Mitchell 2000).

Most unfortunate is that the list of dissidents in the history of psychoanalysis includes some of its most creative authors: Lacan, Sullivan, and Kohut are just some of the examples of those who founded their own schools, while Ferenczi, Fairbairn, Winnicott, and Bowlby, are among those who did not. Therefore, Otto Kernberg recommended that psychoanalytic institutes should be evaluated according to the following criterion: "Are multiple psychoanalytic theories and clinical approaches respectfully taught?"; the sad conclusion was that, in most cases, the answer is "no" (Bergmann 2004, 96-97).

Various reasons were offered to explain the problem away (Bergmann 2004): resistance toward Freud's personality; a basic attitude of ingratitude 
and criticism; unsuccessful training analyses; structural flaws in the organization of training institutes-this last one is most persistently advanced by a former president of the IPA (Kernberg 1986, 1996, 2000); the requirement of conviction in the postulates of psychoanalysis-and convictions can be found and lost; an unclear idea of what constitutes progress in psychoanalysis and how it can be verified (Stepansky 2009).

Admittedly, there were efforts to mend the divides, although it seems that none succeeded. I will give a short overview of the most influential solutions for the lack of integration.

The first is derived from the supposed common scientific core. Freud exposed psychoanalysis as a natural science with a specific hermeneutic method for the exploration of complex mental states. The ideal changed from biology to paleontology to physics, and Freud wrote in terms of drives, primal hordes, excitation, etc. It was not only that he wanted to show how psychoanalysis can be relevant to physical and biological sciences, but also that he hoped his method would unify the field and clearly show who is a psychoanalyst and who is not. The first demarcation was drawn on the line of the sexual etiology of neuroses: everyone who refused to accept this basic tenet was not to be considered a psychoanalyst. Then, as Freud wrote to Georg Groddeck (1977), everyone who was devoted to the analysis of transference and resistances could be considered a psychoanalyst. And as time went on, these definitions multiplied: Hartmann studied processes of adaptation, Klein unconscious phantasies, Sullivan interpersonal experiences, Lacan had a passion for linguistics, Spitz observed hospitalized children, Bowlby worked with juvenile thieves, Kohut claimed that the essential method of psychoanalysis was empathy, and so on. Agreement was hard to reach even when it came to defining the core of psychoanalysis. In many instances, a previous generation would say that what the youngsters were doing was not psychoanalysis. Of course, this was based only on personal authority and could not be substantiated with any clinical or scientific evidence.

At this very moment, many hope that contemporary scientific trends will help us overcome the fragmentation of our field. More and more institutes provide training in research methodology, there are specialized journals in neuropsychoanalysis, evidence-based approaches to the effectiveness of psychoanalysis as therapy have emerged and to psychoanalytic training as a specific form of education are beginning to take root (Dimitrijevic 2018). Most analysts, however, see these trends as irrelevant for their clinical work and even as non-psychoanalytic. Their ranks include Freud himself and his 
daughter Anna, Melanie Klein, Winnicott, Kohut, Andre Green, and many, many others.

A good number of our colleagues think that psychoanalysis should be regarded as an original clinical discipline. It may sound strange that this idea was first articulated as late as 1924. In their joint book Development of Psychoanalysis, Sándor Ferenczi and Otto Rank proposed that instead of metapsychology, we should use analytic situation as a defining feature of psychoanalysis. All this was in part a reaction to Freud's introduction of the death drive, since the authors believed that he had paid far more attention to abstract concepts than to issues of clinical technique. In the words of one of the foremost historians of psychoanalysis: "Psychoanalytic method had fossilized, [Ferenczi] believed, and become an overly intellectualized process of educating patients about the contents of their unconscious" (Makari 2008, 352). This was the moment when the reorientation of psychoanalysis was initiated, and transference repetitions were suggested as its core. "Everything relevant to the cure of neurosis happen[s] in the analytic situation and the transference. Interpretations should focus on reactions to the analyst, for in those reactions lay infantile repetitions" (353) - we take these words for granted, but they were revolutionary in the mid-1920s and led to Freud's dismissal of two men he had considered worthy of being his heirs and, less importantly, one whom he had wanted to become his son-in-law.

If there is anything that can unite us now, almost ninety years later, it is our motivation to investigate complex mental phenomena as they unfold in the transference situation guarded by the safe-enough setting. From our experiences of personal analyses and supervisions, to the impact of psychoanalysis on philosophy and culture of our times, to newspaper cartoons and Hollywood movies, transference equals psychoanalysis for many people. However, we have managed to split over issues concerning what transference is and how best to deal with it: some interpret right away, others wait until the transference is fully developed, some hardly interpret at all; some focus on the here and now others home in on relationships with significant others; many emphasize repetitions from early development; some insist that no enactments on the side of the analyst are allowed if they cannot be neutralized by interpretation; others find enactments impossible to avoid and good leaders if reflected upon; some allow the use of medication, while others use only psychoanalytic counseling. Again, different approaches and conceptions lead to bitter fights and the confusion of tongues among the rival schools. 
Finally, throughout the century it was thought that psychoanalysis can reach its integration through one international organization. It was a vision of, again, Sándor Ferenczi, and it should have had the purpose of unifying Freud's disciples and controlling the quality of work self-proclaimed as psychoanalytic-somewhat curiously, because when formed, in 1910, it had less than fifty members. It was only after the World War I that Freud agreed to obligatory training analyses (Makari 2008), and in the following decade that Karl Abraham (2008) introduced the tripartite model of psychoanalytic training that strengthens our professional identities and gives us the inner sense of our identity as psychoanalysts. Still, in the last sixty years, psychoanalytic organizations bloomed everywhere, often without interest for existing ones, which were sometimes hostile to them: Lacanian organizations in France and Latin America, interpersonal and relational organizations in the United States, the many non-IPA institutes in Central Europe, etc. I have met many young colleagues with strong devotion to psychoanalysis who are enrolled in training programs not recognized by the IPA, and, especially in the United States, many senior analysts and important authors wrote that they had no interest in either the American or international associations (Mitchell 2000).

Why is this issue important? My intention is to open a discussion that will not be resolved quickly. Basically, I wish to argue that this situation will present the most perilous problem for those who will practice psychoanalysis in the decades to come, and that the future of our discipline may well depend on our capacity to create a cohesive field.

In one of the most important books published in the field of psychoanalysis in recent years, Paul Stepansky tries to turn our attention to the fact that psychoanalysis has become a marginal phenomenon in contemporary Western culture. After several decades of enormous - and, to my mind, somewhat inexplicable-success and influence, psychoanalysis has lost psychiatric clinics to biological approaches and cognitive-behavioral therapy, and it has lost universities to paradigms devoted to more easily controllable and testable phenomena. Judging by any objective criterion one can think of, psychoanalysis is not the leader in the field. On the one hand, other approaches solicit more practitioners and gather more clients; on the other, psychoanalysis can boast only a handful of doctoral programs and research institutes, highest-quality journals, high positions on citation indexes. Something has to be done!

I think that the main reason for a vigorous response to its current status is that the world needs psychoanalysis and has not come up with anything 
that can replace it. On the general level, I refer to the idea first articulated by Thomas Mann (1956) on the occasion of Freud's eightieth birthday: the project of the Enlightenment has to be informed by psychoanalysis or it remains a naïve utopia - that is, societal reforms need to include our insights into human unconscious. And on the individual level, in the world of unprecedented acceleration, "in times when time is a scarce commodity" (Gergen 2000), the psychoanalytic setting may easily be the only safe resort that allows us the privilege to admit and experience the pains of growing up in a world that seems to do nothing but invent new ways to deny that same pain. Finally, there is growing evidence showing that psychoanalysis is superior to all other forms of psychotherapy, and this is especially the case in terms of its effects on post-treatment development (Schedler 2010).

Yet, how does this immensely important discipline react to its current marginalization? Stepansky shows very convincingly that as psychoanalysis is less recognized by other fields, it grows more internally fragmented, becoming "a loose federation of psychoanalytic subcommunities" (2009, xi). The more they ignore us, the more we create divides among ourselves and take an exclusionary stance towards our closest collaborators. Strangely, common external adversity does not make us more but rather less cohesive. When they tell us "You are irrelevant," our response is "This is not a toilet-breast, this is a mirroring self-object."

To sum up, it seems that disintegration has been inevitable throughout the entire history of psychoanalysis. That is why we need to think about solutions that have already been suggested and use them to overcome the problem. It will not disappear on its own, and even the newest solutions do not seem to be effective enough: many believe that psychoanalysis needs a stronger alliance with the natural sciences; Otto Kernberg (2004) believes that cross-fertilization between different psychoanalytic schools has already begun and that we need only wait for its effects to bear fruit; in a powerful finale to Psychoanalysis at the Margins, Stepansky $(2009,312)$ wrote: "I am increasingly convinced that the survival of the profession in the foreseeable future lies beyond the couch and outside the consulting room."

I strongly believe that Stepansky's use of the word "survival" is justified. Four- or five-times-a-week "non-training" couch analyses that last for many years and delve into the dark regions of the unconscious are becoming rare; in fact, they take up a tiny percentage of the clinical practice of those of us who are not training analysts. It may well be the ultimate task of our generation, those of us who are soon to become psychoanalysts, to foster the survival of our 
field and our professional identities against the opposition that has swept us out of the mainstream; but even more so, to protect us against our own tendencies toward inner disintegration. To protect this core and unite the field, we have to find out where the curse of inner hostility comes from and how to overcome it. In order to better help our clients and remain relevant for them, we need to start healing psychoanalysis from the dark forces that seem inherent to it.

\section{REFERENCES}

Bair, Dierdre. 2003. Jung: A Biography. Boston, MA: Little, Brown.

Bergmann, Martin S., ed. 2004. Understanding Dissidence and Controversy in the History of Psychoanalysis. New York: Other Press.

Bonomi, Carlo. 1999. "Flight into Sanity: Jones's Allegation of Ferenczi's Mental Deterioration Reconsidered." International Journal of Psychoanalysis 80, no. 3: 507-42.

Dimitrijevic, Aleksandar. 2011. "Paul E. Stepansky: Psychoanalysis at the Margins." Clinical Social Work Journal 39, no. 3: 321-22.

- 2018. "A Mixed-Model for Psychoanalytic Education." International Forum of Psychoanalysis 27, no. 2: 121-25.

Ellenberger, Henri. 1970. The Discovery of the Unconscious: The History and Evolution of Dynamic Psychiatry. New York: Basic Books.

Ferenczi, Sándor, and Otto Rank. (1924) 1986. The Development of Psychoanalysis. Madison, CT: International University Press.

Gergen, Kenneth. 2000. "The Self: Transfiguration by Technology." In Pathology and the Postmodern: Mental Illness as Discourse and Experience, edited by Dwight Fee, 100-15. Sage Publications.

Goffman, Erwin. 1961. Asylums: Essays on the Social Situation of Mental Patients and Other Inmates. New York: Free Press.

Groddeck, Georg. 1977. The Meaning of Illness: Selected Psychoanalytic Writings. Edited by Lore Schacht. Translated by Gertrud Mander. London: Maresfield Library.

Grosskurth, Phillis. 1991. The Secret Ring: Freud's Inner Circle and the Politics of Psychoanalysis. Reading: Addison-Wesley Publishing Company.

Kernberg, Otto. 1986. "Institutional Problems of Psychoanalytic Education." Journal of the American Psychoanalytic Association 34, no. 4: 799-834.

— 1996. "Thirty Methods to Destroy the Creativity of Psychoanalytic Candidates." International Journal of Psycho-Analysis 77, no. 5: 1031-40.

— 2000. "A Concerned Critique of Psychoanalytic Education." International Journal of Psycho-Analysis 81, no. 1: 97-120.

- 2004. "'Dissidence' in Psychoanalysis: A Psychoanalytic Reflection." In Understanding Dissidence and Controversy in the History of Psychoanalysis, edited by Martin S. Bergmann, 129-46. New York: Other Press.

Makari, George. 2008. Revolution in Mind. New York: HarperCollins.

Mann, Thomas. (1936) 1956. "Freud and the Future." International Journal of Psychoanalysis 37: 106-15. 
Mitchell, Stephen. A. 2000. "Between Philosophy and Politics." In Psychoanalytic Conversations: Interviews with Clinicians, Commentators, and Critics, edited by Peter L. Rudnytsky, 101-36. Hillside, NJ \& London: The Analytic Press.

Segal, Hanna. 2006. "Reflections on Truth, Tradition, and the Psychoanalytic Tradition of Truth." American Imago 63, no. 3: 283-92.

Shedler, Jonathan. 2010. "The Efficacy of Psychodynamic Psychotherapy." American Psychologist 65, no. 2: 98-109.

Stepansky, Paul E. 2009. Psychoanalysis at the Margins. New York: Other Press. 


\title{
Parallels, Intersections, and Clashes: Journeys through the Fringes
}

\author{
Dennis Fox
}

My work in critical psychology over the past three decades reflects shifting theoretical concerns, political projects, and personal experiences, motivated chiefly by an interest in radical social change and a sense that psychology as a discipline helps shape and sustain an unjust and unsatisfying status quo (Fox 2012; Fox et al. 2009). This seemed to me obvious ever since my immersion in 1970s anarchist politics, when I came to understand anarchism as a psychopolitical movement seeking to foster both autonomy and mutuality without sacrificing one for the other (Fox 1985, 2014). This balancing act is complicated by psychology's reduction of systemic strains to a collection of individual problems and, certainly in its mainstream United States version, its enshrinement of individualism as the primary value. My orientation within critical psychology, thus, as within the Radical Psychology Network that I co-founded in 1993 (http://radpsynet.org), has been to challenge mainstream assumptions about the interplay between human nature and the larger society and to address psychology's role as a pacifying agent.

Several impressions have stuck with me since the 1970s. First, anarchist political thinking has always stressed working towards both systemic change and personal change at the same time. Second, despite this theoretical awareness, anarchists as individuals, wary of psy-science's societal role and the dangers of psychologizing political issues, often avoid deep self-exploration. And third, many anarchists, like activists more generally—and like many academics-fumble through tensions they might navigate more easily if they had greater personal and interpersonal knowledge and skills. 
Elsewhere I have explored these issues in relation to psychology's various guises: academic discipline, therapeutic profession, psychoanalytic understanding, and force of popular culture (Fox 2011). Critical psychologists, like anarchists, know that focusing on the personal, on therapy and "understanding ourselves" better, on "personal growth," can be just one more trap that distracts us from political action. Ironically, this suspicion of psychology coincides with awareness that much of the anarchist project is inherently social-psychological. Emma Goldman wrote more than a century ago that "the problem that confronts us today, and which the nearest future is to solve, is how to be one's self and yet in oneness with others, to deeply feel with all human beings and still retain one's characteristic qualities" (cited in Shukaitis 2008 , 12). Early anarchists insisted that "changes in personal aspects of life, such as families, children, sex should be viewed as political activity" (Leeder $1996,143)$. A century later, "Salmon" $(2010,13)$ notes "It is easy to talk about challenging the system and forget about challenging ourselves at the same time. It is not about putting one above the other, but realizing that both have to go hand in hand to be truly revolutionary."

Over the past six years I have explored groups that focus on the kinds of self-knowledge and skills that radical activists and critical psychologists often dismiss. From the beginning, I hoped to gain more insight and learn new skills without disappearing into self-absorption and passivity. I wanted to begin answering for myself, in a personal and practical way, questions that Abraham Maslow asked in his 1967 course on Utopian Social Psychology: "How good a society does human nature permit? How good a human nature does society permit? What is possible and feasible? What is not?" $(1971,212)$. These questions are addressed more or less explicitly in a wide range of nonacademic settings-intentional communities, alternative schools, political mobilizations. What I chose to do was explore them along the fringes of the human potential movement. What drew me in was this dilemma: if we understood our needs and wants better and knew how to interact more effectively, we might be better off both individually and collectively. But, aware of the dangers of self-absorption, we resist putting energy into rethinking ourselves. So what's an activist to do? 


\section{Communication, Connection, Community}

Reassuringly, some forms of humanistic and even New Age thought aim for, and claim compatibility with, significant social change (McLaughlin and Davidson 2010; Rosenberg 2004; Satin 1979). At the same time, it is worth acknowledging up front that many participants in this alternative culture insist that the only way to change the world is to work (only) on changing ourselves. Therapy and self-help books and workshops continue to emphasize individual solutions to problems caused by social distortions (Justman 2005), whether within psychotherapy's core or in humanistic approaches growing out of Western psychology, Eastern philosophy, and New Age mysticism. This is the case even though many of the alternative world's answers to Maslow's questions can be traced to politically conscious radical psychology and psychoanalysis. Wilhelm Reich's (1942) exploration of the connection between sexual repression and fascism remains central even if unacknowledged, as do later variants of Marxist, feminist, and other traditions. Reich himself built on the work of the anarchist psychoanalyst Otto Gross, who broke away from Freud to raise "questions about the freedom of the individual in relationship to social norms and traditions." "Gross believed that "[w]hoever wants to change the structures of power ... in a repressive society, has to start by changing these structures in himself" (Sombart 1991, cited in Heuer n.d.). Similarly, the anarchist psychiatrist Roberto Freire's 1970s somatherapy, a body-focused group performance therapy building on Reich, tries "to understand the sociopolitical behavior of individuals starting from what happens in their daily lives."2 Paul Goodman, another anarchist psychologist, emphasized societal context in his contribution to gestalt therapy (Perls et al. 1951).

Despite these antecedents, the groups and approaches I have explored deemphasize or ignore political analysis and action in favor of personal growth and interpersonal dynamics primarily related to communication and connection. Not defining themselves as political, they attract people from a range of political and apolitical identities, and yet their purposes and methods are arguably consistent with many critical and radical values. Aiming to shake us out of complacency toward new habits, goals, motivations, and emotions, they

1 “Who Was Otto Gross?" Retrieved December 24, 2010. http://www.ottogross.org.

2 "Somatherapy." Wikipedia. Retrieved December 24, 2010. http://en.wikipedia.org/ wiki/Somatherapy. 
parallel to varying degrees political calls to rethink things we have taken for granted about human nature and hierarchy, capitalism and materialism, monogamy and sexuality; they emphasize working with others to alter lifelong habits, emotions, fears, and hopes. The goal, for many, is not just to focus inward but to create ongoing networks and communities. Some hope to spark even broader societal change.

These explorations have challenged my own assumptions and habits and tested my ability to be patient with new language, styles, and ways of looking at myself and the world. Three groups in particular have drawn me in despite my hesitations: Nonviolent Communication, the Human Awareness Institute, and Network for a New Culture. Each teaches skills useful for challenging assumptions and practices related to mainstream values, practices, and goals. Despite differences in emphasis and scope, all three have in common an understanding of human behavior rooted in humanistic or radical psychology and an awareness that changing the way people think, feel, and live means learning how to enhance communication, connection, and community. Elements of humanistic psychology, cognitive and gestalt therapy, and Reichian analysis are evident in the general emphasis on belief and emotion, body and mind, and self and culture.

\section{Nonviolent Communication (NVC)}

Marshall Rosenberg (2003) trained as a clinical psychologist under Carl Rogers but soon decided that diagnosis is irrelevant to helping people meet their needs. Growing out of his work with civil rights activists in the 1960s, he developed a method of communication designed to avoid heated instant responses. Nonviolent Communication (sometimes called Compassionate Communication), the most mainstream of the three approaches described here as well as the most targeted in scope, is taught today in workshops around the world. According to the website of the Center for Nonviolent Communication: "NVC begins by assuming that we are all compassionate by nature and that violent strategieswhether verbal or physical-are learned behaviors taught and supported by the prevailing culture. NVC also assumes that we all share the same, basic human needs, and that each of our actions are a strategy to meet one or more of these needs." Given NVC's assumption that all feelings stem from universal indi-

\footnotetext{
${ }^{3}$ See the website of the Center for Nonviolent Communication at http://cnvc.org.
} 
vidual needs, the challenge in communication, especially difficult communication, is to learn how to seek mutually beneficial strategies to meet both side's needs. This is possible only with some learned awareness that feelings such as anger, frustration, or annoyance might be linked to unmet needs, for example for respect, belonging, intimacy, or equality. Similarly, feeling loving, warm, thankful, or trusting comes from meeting these or other needs. Inherent in this framework is that communication flows more productively when it focuses on potential strategies to meet needs rather than on emotion-based demands. It means that "getting in touch with your feelings" requires not just recognizing and expressing them but also understanding what needs they stem from and then considering various ways to meet them. For Rosenberg, the skills to act on this awareness are crucial to moving not just towards personal growth but towards social change (Rosenberg 2004).

Over the past few years I have taken two daylong and several shorter NVC training workshops, and have been in close contact with many NVC trainers and adherents. I have seen NVC's specific methodology and terminology used with dramatic effect, and I have found it helpful in some of my own difficult interactions. I have also seen it used clumsily and mechanically, sometimes by people new to the practice who rarely stray from the training routine and rote jargon. My sense is that NVC is useful especially in interpersonal relationships where both parties want to maintain the relationship-but in contrast to mediation, which in practice often simply splits the difference between two conflicting perspectives, NVC seeks win-win outcomes that meet the needs of both sides. And often it succeeds.

Rosenberg and others report using the technique in a wide range of larger conflicts, from urban gangs to Northern Ireland to Israel-Palestine. Rosenberg's accounts are anecdotal and impressionistic but often impressive. Although NVC seems to me less adaptable to settings where the parties are unwilling to engage in mutual humanization, an increasing number of NVC practitioners do attempt to bring the practice into political conflict zones and to teach NVC with a specific focus on power relationships, race and ethnicity, and histories of long-term hostility (e.g., Miki Kashtan's workshops on Leveraging Your Influence). A group of NVC trainers organizes workshops called The Nonviolent Leadership for Social Justice Retreat, which focus on using NVC for issues related to race, ethnicity, and social class. In my own experience as a faculty union member, an approach similar to NVC used in campus contract negotiations led to a much better outcome than had been the case during earlier traditional negotiations. 
NVC may be especially relevant to internal conflict within organizations and political movements. An example: in the winter of 2012, Occupy Boston splintered and began to fade away. One significant factor was that many activists were unable or unwilling to work with people with whom they had personal conflicts or personalized political differences. Despite efforts to bring people together and even to try NVC, activists on both sides resisted this kind of difficult conversation. Rather than explore strategies to meet needs, most either retreated to smaller projects where they could avoid people they did not like or dropped out of the movement completely.

My Occupy Boston experience was not unusual. The same factionalization occurred across the Occupy terrain. More important, it mirrored difficulties faced by activist groups time after time, year after year. Unproductive meetings, power imbalances, oppressive actions, competitiveness, jealousiespolitical work frequently collapses in the face of interpersonal and group tensions. This is not to say that Occupy or any other group should last forever. What seems clear to me, though, is that political work would often proceed more effectively if activists had better insight into their own emotional reactions and those of others, and if they had the skills to explore those reactions with less defensiveness, hostility, and certainty.

As with most tools, NVC can be used for both positive and negative ends. Recognizing the link between feelings and underlying needs can help someone manipulate others, and NVC's way of redirecting heated communication to calmer discussion strikes some as artificial and deflating, or even oppressive; the Nonviolent Leadership for Social Justice Retreat explicitly addresses this perception, suggesting ways to make NVC more welcoming to people of color. But although these and other cautions are important, they do not detract from the benefits of learning how to get beneath the surface and move ahead together.

\section{Human Awareness Institute (HAI)}

The Human Awareness Institute, founded in 1968, has a broader agenda than NVC. Communication remains crucial, but especially as a tool in rethinking perspectives and learning skills explicitly related to "love, intimacy, and sexuality." Like NVC, HAI too began with a psychologically oriented creator, Stan Dale, with a background in Transactional Analysis and a doctorate in Human 
Sexuality. ${ }^{4}$ Offering weekend workshops mostly in the United States but also in Canada, Germany, the UK, Australia, and occasionally elsewhere, HAI explains its mission in broad terms:

The Human Awareness Institute (HAI) empowers individuals to be potent, loving, contributing human beings. HAI promotes personal growth and social evolution by replacing ignorance and fear with awareness and love.

HAI aims to create a world where people live together in dignity, respect, understanding, trust, kindness, compassion, reverence, honesty and love. The Human Awareness Institute is committed to creating a world where everyone wins. ${ }^{5}$

Despite these comfortable generalities, and unlike NVC's easy compatibility with mainstream lives, HAI aims to shatter common assumptions and habits, particularly those related to self-image, relationships, and sexuality. Workshops encourage participants to explore aspects of themselves they take for granted, to consider alternative perspectives, and to challenge their own boundaries-often in the zone between friend and lover-in safe, supportive settings. Although HAI as an organization has no explicit political agenda, Dale's work developed with his late-1960s political immersion. Going back to Reich, Dale believed that understanding and breaking through sexual repression was crucial for creating a world of love and peace, though HAI adherents today differ widely among themselves about whether political activism is, or should be, a personal priority, and even about whether it is possible to change anything outside of oneself. The central focus is resolutely individualistic.

HAI offers a series of nine weekend workshops designed:

to encourage participants to explore self-esteem, body image, boundaries, moving out of your head and into your heart, speaking your truth, and, more importantly, knowing what your truth is. . . The workshops are also about communication and learning valuable, practical communication skills. We specialize in workshops that encompass

\footnotetext{
4 See more on the founder at the website of the institute: "Stan Dale. In Memoriam 1929-2007." http://w11.hai.org/stan/.

${ }^{5}$ HAI (Human Awareness Institute) website, http://hai.org. Retrieved August 1, 2015.
} 
all relationships with an emphasis on empowering people to make the best choices for themselves every minute of every day. ${ }^{6}$

The website's FAQ notes that Level 1 includes an invitation to remove clothing as well as reassurance that all HAI exercises are optional, with participants always "at choice," a term often used, explained, and, based on my participation at Level 1 and 2 workshops, accepted in practice. Exercises begin with activities such as eye gazing, face touching, one-to-one inquiry and disclosure, along with discussion of body image, relationship and sexual histories, and so on. In regions where large numbers of participants live, there are periodic get-togethers, parties, support groups, and active email interaction; members often talk about being part of the HAI Community.

Not everyone who participates in HAI comes away with positive impressions. The invitation to reveal deep parts of oneself, on top of the nudity and one-to-one disclosure, can lead to leaps in personal self-awareness but also to unexpected and unwelcome shifts in self-awareness, behavior, and relationship complexity. Some have accused the group of being a cult or tolerating abusive behavior, though there is little evidence of this and it has not been my experience.

More of a challenge for me has been adjusting to some exercises and language conventions that elicit eye rolling. Yet I am learning patience, appreciating new insights about aspects of myself I had not previously explored in a systematic way. I have come to appreciate HAI members who have learned to communicate about their wants and needs in what seem to me satisfying and useful ways. Although HAI's lack of an explicit tie to societal change troubles me, I have chosen to remain at least on the outskirts of the community.

\section{Network for a New Culture (NFNC) ${ }^{7}$}

In contrast to NVC, which teaches a specific approach to communication, and unlike HAI, which offers a highly structured workshop environment to guide participants through increasingly challenging experiences, Network for a New Culture is more eclectic. At ten-day camps on the US West Coast, East Coast,

\footnotetext{
${ }^{6}$ HAI (Human Awareness Institute) website, http://hai.org. Retrieved August 1, 2015.

7 See the website of the Network for a New Culture at: http://nfnc.org.
} 
and in Hawaii, and at frequent weekend gatherings in various parts of the United States, NFNC creates settings that invite adult participants to explore their emotional, behavioral, and sexual assumptions. NVC often makes an appearance, along with other approaches to communication, and there may be a day-long introduction to HAI but also workshops on other forms of connection and personal growth such as Tantra, polyamory, body movement, dance, and games, as well as - at times-workshops on the link between personal lives and economic and political change. Like HAI, New Culture events are generally clothing optional, with an emphasis on accepting relationship variations and creating a sex-positive culture.

To a greater extent than NVC and HAI, NFNC talks about creating a "new culture" as part of a transition to broader social change. The website language often resembles NVC and HAI - "NFNC seeks to build a sustainable, violence-free culture through exploring intimacy, personal growth, transparency, radical honesty, equality, compassion, sexual freedom, and the power of community." But NFNC gatherings and online discussions place somewhat more emphasis on creating actual community and on cultural change than do the other groups. At the five NFNC summer camps I have attended, and at many shorter gatherings, presenters have addressed systemic political and economic issues. Although NFNC is still not a political group, and most participants do not explore the political level as frequently or fervently as they do personal growth, intimacy, and sexuality, there is some effort to place personal growth and interpersonal connection in a broader societal context.

Initially, NFNC was inspired in part by two European intentional communities with a more explicit political emphasis: ZEGG, in Germany, ${ }^{8}$ founded in 1991, and Tamera, ${ }^{9}$ in Portugal, founded in 1995. Both ZEGG (a German acronym for "Center for Experimental Cultural Design") and Tamera were based on the work of Dieter Duhm, a sociologist with a background in psychology, an early interest in Wilhelm Reich, and a belief that free love-or "love free of fear"-is necessary for creating a world at peace. ${ }^{10}$ For ZEGG and Tamera both, sexual freedom is not just an end in itself but a path to radical change. In keeping with its political aims, Tamera, where Duhm lives, has established Peace Villages in other countries: Columbia, Brazil, Kenya, and a short-term effort in Palestine.

\footnotetext{
${ }^{8}$ See the website for ZEGG: http://www.zegg.de.

9 See the website for Tamera: http://www.tamera.org.

10 See the website of Dieter Duhm for more information: http://www.dieter-duhm.com.
} 
For NFNC in the United States, on the other hand, where most members know nothing of Duhm's work or the role of political thought and practice in ZEGG and Tamera, ridding ourselves of sexual repression and traditional views of relationships is, for most participants, an apolitical end in itself, personal growth for its own sake. What NFNC did take from ZEGG and Tamera is their system to help work through group tensions, especially tensions related to sexual jealousy, competitiveness, and possessiveness. Both communities use a regularly scheduled group forum where participants can choose to display their inner and interpersonal struggles to the larger group. For Network for a New Culture, this forum, which NFNC refers to as ZEGG Forum, is a central community practice, eliciting often-intense emotions that can lead to increased empathy, understanding, and connection.

I remain part of NFNC despite having lowered my initial expectations and despite disappointment at the group's difficulty addressing some internal decision-making and power dynamics. As a workshop setting and as a network of likeminded people, NFNC has been, for me, a place to face significant personal challenges. But it is neither a political movement nor an intentional community, even though some members do live together in small groups and engage in political action outside the group. There seems to me little prospect of creating a larger ongoing community or a larger political project in the United States; ZEGG and Tamera, in contrast, both of which I visited briefly within the past year, have more potential for linking the personal and the political.

\section{And Now?}

It should be apparent that my explorations have brought mixed results. On the one hand, the positive: I have learned a lot about my own habits and assumptions, about patterns in my life, and about healthier, or at least potentially more satisfying, directions to turn, and I have also learned some useful skills to help me along. I have developed deep connections with many people, including some with interests and perspectives I would unlikely have appreciated in the past and some who use their new insights and skills to work for change in their own communities as well as in the larger society. And I have had a lot of fun.

But it is not all positive. I have been frustrated doing this work with people who, more often than not, are not drawn to political thinking and action, in settings mostly focused on the individual and the interpersonal 
even while understanding that personal difficulties often have social and cultural origins. And-as might be expected-I have spent less time on direct political work than I might have without the lure of fixing myself. So my challenge remains: how to work on myself while also working beyond myself.

I continue to think it possible to learn skills and create communities to help us live closer to what we imagine is possible. While I agree with the anarchist Uri Gordon, who cautions that "these practices and lifestyles are in danger of congealing into a self-referential subculture that detracts from other areas of activity (e.g., direct action, propaganda, solidarity work)," I appreciate his adding "there is no reason why they should have to come at the expense of these."11 Also useful is Marshall Rosenberg's acknowledgment $(2004,5-6)$ that "spirituality can be reactionary if we get people to just be so calm and accepting and loving that they tolerate the dangerous structures. The spirituality that we need to develop for social change is one that mobilizes us for social change. It doesn't just enable us to sit there and enjoy the world no matter what."

Perhaps my own struggle with competing pulls has to do with the level of political change I imagine. Perhaps I am too impatient. In any case, the relevant question is whether psychology, in any of its therapeutic, research, or alternative guises, can contribute to a culture in which people live more fulfilling lives while also working toward a world that makes better lives possible for everyone. For me that is still an open question, but one worth exploring further.

\section{REFERENCES}

Fox, Dennis R. 1985. "Psychology, Ideology, Utopia, and the Commons." American Psychologist 40: 48-58.

_ . 2011. "Anarchism and Psychology." Theory in Action 4: 31-48.

- 2012. "Critical and Radical Psychology." In Encyclopedia of Peace Psychology, edited by Daniel J. Christie, 283-87. Hoboken, NJ: Wiley-Blackwell.

— . 2014. "Anarchism." In Encyclopedia of Critical Psychology, edited by Thomas Teo, 89-94. New York: Springer.

Fox, Dennis, Isaac Prilleltensky, and Stephanie Austin, eds. 2009. Critical Psychology: An Introduction. London: Sage Publications.

11 Gordon, Uri, “Lifestyles.” Anarchist Academics listserv. Accessed May 27, 2010. http://lists.mutualaid.org/mailman/listinfo/anarchist.academics. 
Gordon, Uri. 2005. Liberation Now: Present-Tense Dimensions of Contemporary Anarchism. Paper presented at Graduate Student Conference "Thinking the Present: The Beginnings and Ends of Political Theory," University of California, Berkeley, May 27.

Heuer, Gottfried. n.d. “Otto Gross, 1877-1920: Biographical Survey.” Retrieved December 24, 2010. http://www.ottogross.org/english/documents/BiographicalSurvey. html.

Justman, Stewart. 2005. Fool's Paradise: The Unreal World of Pop Psychology. Chicago: Ivan R. Dee.

Leeder, Elaine. 1996. "Let our Mothers Show the Way." In Reinventing Anarchy, Again, edited by Howard J. Ehrlich, 142-48. San Francisco: AK Press.

Maslow, Abraham H. 1971. The Farther Reaches of Human Nature. New York: Penguin.

McLaughlin, Corinne, and Gordon Davidson. 2010. The Practical Visionary: A New World Guide to Spiritual Growth and Social Change. Unity Village: Unity House.

Perls, Fritz, Ralph Hefferline, and Paul Goodman. 1951. Gestalt Therapy: Excitement and Growth in the Human Personality. New York: Julian.

Reich, Wilhelm. (1942) 1970. The Mass Psychology of Fascism. New York: Farrar, Straus \& Giroux.

Rosenberg, Marshall B. 2003. Nonviolent Communication: A Language of Life. Encinitas: PuddleDancer Press.

— 2004. The Heart of Social Change: How to Make a Difference in Your World. Encinitas: PuddleDancer Press.

"Salmon." 2010. "Green Anarchism and Polyamory." Dysphoria 1: 6-19. Accessed August 1, 2015. http://dysophia.files.wordpress.com/2010/05/polyamory1-6_web.pdf.

Satin, Mark. 1979. New Age Politics: Healing Self and Society. New York: Dell.

Shukaitis, Stevphen. 2008. "Questions for Aeffective Resistance." First Anarchist Studies Network Conference, Loughborough, UK, September 5. 


\section{About the Authors}

Zsuzsanna Agora, Research Fellow, Dean's Office, Faculty of Humanities, University of Pécs, Hungary.

Shaul BAR-HAim, Lecturer, Department of Sociology, University of Essex, UK.

BALÁzs Berkovits, Postdoctoral Research Fellow, Bucerius Institute, University of Haifa, Israel.

Zsuzsa BокоR, Research Fellow, The Romanian Institute for Research on National Minorities, Cluj-Napoca, Romania.

Anna Borgos, Research Fellow, Institute of Cognitive Neuroscience and Psychology, Hungarian Academy of Sciences, Budapest, Hungary.

Julia Borossa, Associate Professor and Director of the Centre for Psychoanalysis, Middlesex University, UK.

Márta Csabai, Professor, Department of Personality, Clinical, and Health Psychology, University of Szeged, Hungary.

Aleksandar Dimitrijević, Psychoanalyst, Research Associate, International Psychoanalytic University; Psychoanalytisches Institut Berlin, Germany.

Ferenc Erős, Professor Emeritus, PhD-program in Theoretical Psychoanalysis, University of Pécs, Hungary.

Dennis Fox, Emeritus Associate Professor of Legal Studies and Psychology, University of Illinois-Springfield, US.

Melinda Friedrich, Junior Research Fellow, Institute of Cognitive Neuroscience and Psychology, Hungarian Academy of Sciences, Budapest, Hungary.

Stephen Frosh, Professor, Department of Psychosocial Studies, School of Social Sciences, History and Philosophy, Birkbeck College, London, UK. 
Júlia Gyimesi, Associate Professor, Department of Personality and Clinical Psychology, Pázmány Péter University, Budapest, Hungary.

György PÉTER HÁRs, Independent Literary Historian, Historian of Psychoanalysis, Budapest, Hungary.

Gordana Jovanović, Professor, Department of Psychology, University of Belgrade, Serbia.

Melinda Kovai, Associate Professor, Department of Social Psychology, Faculty of Social Sciences, Eötvös Loránd University, Budapest, Hungary.

Emese Lafferton, Assistant Professor, Department of History, Central European University, Budapest, Hungary.

DórA MÁRIÁsI, PhD-student, Institute of Psychology, Eötvös Loránd University, Budapest, Hungary.

Ruslan Mitrofanov, Chair of, Russian and Asian Studies, Ludwig-Maximilian University, Munich, Germany.

Michael Molnar, former director of the Freud Museum, London, UK.

Orsolya PApp-Zipernovszky, Assistant Professor, Department of Personality, Clinical and Health Psychology, University of Szeged, Hungary.

VirÁg RAB, Assistant Professor, Department of Modern History, University of Pécs, Hungary.

Raluca Soreanu, Wellcome Trust Fellow in Medical Humanities, Department of Psychosocial Studies, Birkbeck College, London, UK.

Philip Thomas, Writer, and formerly Professor of Philosophy, Diversity, \& Mental Health, University of Central Lancashire, UK. 


\section{Name Index}

\section{A}

Abraham, Karl, 261

Aczél, György, 197, 213-14, 228, 230-31

Adler, Alfred, 41n2, 345

Aichhorn, August, 42

Alexander II (Aleksandr Nikolayevich), 288

Anderson, Warwick, 111n4

Andrássy, Júlia, 29

Arany, János, 119

B

Bak, Róbert, 139

Bakhtin, Mikhail, 154

Balibar, Étienne, 109, 115

Bálint, Alice, 3, 53-75

Bálint, Enid, 57n4

Balint, Michael (Bálint, Mihály), 3, 42, 57-60, 62-64, 66, 71, 74-75, 207

Bálint, Zoltán, 6, 295-302

Barad, Mark, 339

Baudelaire, Charles, 12

Baum, Vicki, 44
Bazhenov, Nikolay Nikolayevich, 287

Beer, Daniel, 274

Bekhterev, Vladimir Mikhailovich, 285-86

Benedek, László, 245

Benedek, Therese, 56

Berény, Róbert, 68

Bergsmann, Emmi, 57, 61

Besserman Vianna, Helena, 145, 159-64

Billig, Michael, 179

Bion, Wilfrid, 161, 346

Bleuler, Eugen, 18, 251

Boehm, Felix, 142-43, 169

Boenhoeffer, Karl, 260

Bonaparte, Marie, 43

Bowlby, John, 314, 346, 347

Bracken, Patrick, 309

Brisley, Stuart, 17, 19

Bródy, Sándor, 41n4

Bruner, Jerome, 167, 178-79

Brücke, Ernst, 247n8

C

Cabernite, Leão, 145-47, 160-62

Canguilhem, Georges, 306 
Castel, Robert, 247, 277

Catherine II (Catherine the Great), 278

Charcot, Jean-Martin, 88, 247n8, 285, 299, 301-2

Charland, Louis C., 307, 312-13

Charles IV (ex-King of Hungary), 257

Chavafambira, John, 155-59

Chekhov, Anton Pavlovich, 288

Chodorow, Nancy, 56

Chorin, Ferenc Sr., 258

Connolly, John, 279

Cook, Cecil, 111n4

Cushman, Philip, 330

\section{D}

Dale, Stan, 358-59

Damousi, Joy, 110

Danziger, Kurt, 170, 172

Davies, Erica, 17

Décsi, Imre, 42

Décsi, Károly, 28-29

Dénes, Zsófia, 41

Derrida, Jacques, 154, 161

Descartes, René, 171-73, 178

Deutsch, Helene, 54, 56

Deutsch, Morton, 179

Didi-Huberman, Georges, 301

Donáth, Gyula, 247-48

Dormándi, Judit, see Dupont, Judith

Dormándi, László, 61n13, 62n14, $63 n 15$

Dostoyevsky, Fyodor Mikhailovich, 82

Dr. Couch (Dr. Arthur S. Couch), $11-14,17,20$

Dreyfus, Hubert Lederer, 274, 288

Drozness, M. J., 287

Du Prel, Carl, 30

Dubovitz, Margit, 53n1

Dubow, Saul, 156

Duhm, Dieter, 361-62

Dupont, Judith (Judit Dormándi), 61, 68,90
Durkheim, Émile, 91, 262

E

Eitingon, Max, 19n5, 47, 142-43, 169

Ellard, John, 314

Ellis, Havelock, 18-21

Engelstein, Laura, 273-74

Etchegoyan, Horacio, 160, 162

Etkind, Alexander, 210

F

Fabian, Johannes, 108, 112

Fairbairn, Ronald, 346

Fanon, Frantz, 107, 156

Feldmann, Sándor, 42, 43, 46, 119n2

Fenichel, Otto, 60n9, 142-44

Ferenczi, Gizella, 68

Ferenczi, Sándor, vi, 3-4, 18n4, 25, 27, 29-31, 33, 40-44, 46n9, 48, 54, 59, $63,68,79,81-92,95-105,108$, $126,137-38,256,261,345-46$, 348-49

Fisher, Michael P., 338

Fliess, Wilhelm, 16n2, 19-20

Flournoy, Theodore, 24, 27

Foucault, Michel, vii, 6, 271-89, 307-8, 315-17

Frances, Allen, 335

Frazer, James, 107, 111

Frederick the Great, 264

Freire, Roberto, 355

Freud, Anna, 11, 13, 54, 56, 59n8, 63, 143,348

Freud, Sigmund, 3, 11-21, 23-25, 33, $39,41,45-46,48,62-63,82-83,85$, $87-90,98,100,107-8,110,138,140$, 143-44, 149-50, 154, 156, 160-61, 163-64, 168-69, 266, 336, 340, 345-50, 355

Freze, Aleksandr Ustinovich, 282

Friedli, Lynne, 325-27

Fromm, Erich, 82

Frosh, Stephen, 154 


\section{G}

Gakkebush, Valentin M., 287

Galton, Francis, 298

Ganushkin, P., 289

Garai, László, 218, 228

Gárdos, János, 27, 29

Gattel, Felix, 16, 18

Gaupp, Robert, 258-60

Gegesi Kiss, Pál, 212-14, 227-28

Gerasimov, Ilia, 276

Gergen, Kenneth J., 171, 330

Glebov, Sergei, 276

Glushkov, N.A., 285-86

Gobineau, Arthur (comte de), 109n2

Goffman, Erwin, 346

Goldman, Emma, 354

Gonda, Viktor, 87

Goodman, Paul, 355

Gordon, Uri, 363

Gornall, Jonathan, 329

Govseev, A. A., 285

Green, Andre, 348

Groddeck, Georg, 42, 103, 347

Gross, Otto, 355

Grünhut, Adolf, 27, 30

Gusti, Dimitrie, 295n4

Gyömrői, Edit, 53n1, 54, 56

György, Júlia, 190n4, 197-98

\section{$\mathrm{H}$}

H. D. (Hilda Doolittle), 19

Hacking, Ian, 311, 317

Hajdu, Lilly, 53n1, 54, 56

Hann-Kende, Fanny, 53n1, 139

Harkai Schiller, Pál, 208n5

Hartmann, Heinz, 347

Harvey, David, 323

Hatvany, Lajos, 40

Hauptmann, Gerhart, 44

Haynal, André, 57n4

Hegedüs, Loránt, 5, 255-58, 261-64, 267

Hegedüs, Margit, 257

Hellenbach, Lazar, 27

Heller, Ágnes, 220n16
Hermann, Alice, 54

Hermann, Imre, 58n5

Hildebrand, Peter, 159

Hitler, Adolf, 142, 267

Hofer, Hans-Georg, 259

Hollós, István, 44, 243-47

Horányi, Annabella, 198

Horváth, László Gábor, 230

Hume, David, 109n2, 313

Hyrtl, Josef, 247n8

\section{I}

Ignotus (Veigelsberg), Hugó, 41n4

Irigaray, Luce, 65n 18

\section{J}

Jaensch, Erich Rudolf, 265-66

Jászai, Mari, 258

Jókai, Mór, 256

Jókay, Jolán, 256

Jones, Edgar, 176

Jones, Ernest, 41n2, 61, 108, 110, 126, $142-44,160,168-69$

Jung, Carl Gustav, 24, 27, 33, 169, 345

\section{K}

Kahn, Eugen, 267

Kalischer, Siegfried, 257, 263

Kant, Immanuel, 264

Kaplunovski, Aleksandr, 276

Kardec, Allen, 27n4, 28

Kardos, Erzsébet, 54

Kardos, Lajos, 213-14, 219-20, 226, 231

Karinthy, Frigyes, $41 \mathrm{n} 4$

Kármán, Tódor, 73

Károlyi, Mihály, 88

Karplus, Paul, 16

Kashtan, Miki, 357

Kassák, Lajos, 190n4

Kelly, John F. (General), 177

Kemper, Werner, 147, 160, 163

Kende, Mór, 242

Kentner, Louis, 68 
Kernberg, Otto, 146, 346

Kharkhordin, Oleg, 274

Kirmayer, Laurence J., 339

Klein, Melanie, 54, 138, 346-48

Knox, Robert, 109

Kohut, Heinz, 346-48

Kolnai, Aurel, 89-90

Kornis, Ignác, 44-47

Korsakov, Sergei Sergeievich, 278, 280-81

Kosztolányi, Dezső, 41 n4

Kovács, Frigyes, 68, 70

Kovács, Vilma, 53n4,54, 56-57, 62-63, $70 \mathrm{n} 20$

Kovalevsky, Pavel Ivanovich, 288

Kraepelin, Emil, 87, 260, 267, 289

Krafft-Ebing, Richard von, 15-16, 19-20, 289

Krainskii, N. V., 288

Krúdy, Gyula, 41

Krueger, Felix, 265-66

Kun, Béla, 88

Kun, Miklós, 220, 231-32

Kürten, Peter, 42n6

\section{L}

Lacan, Jacques, 82, 149, 346-47, 349

Laing, Ronald D., 322

Langer, Marie, 145, 161

Laplanche, Jean, 113, 140

László, László, 32

Laubscher, B.J.F., 156

Lázár-Gerő, Klára, 53n1, 139

Lebovici, Serge, 145, 161

Lechner, Károly, 241-43, 248-49, 251

Lemelson, Robert, 339

Lénárd, Ferenc, 227

Lenin, Vladimir, 220n16

Levchatkin, Vladimir Ivanovich, 278n1, 284-85

Lévy, Kata, 53n1

Lévy-Bruhl, Lucien, 111

Lewis, Sinclair, 44

Liebermann, Lucy, 53n1, 213n10

Limentani, Adam, 146
Lobo, Amilcar, 145-46, 159-63

Locke, John, 171-72

Lothane, Zvi, 169

Löwenfeld, Leopold, 30

Lukács, Georg (György Lukács), 82

Lunbeck, Elisabeth, 239

\section{M}

Mahler, Margaret (Schönberger, Margit), 55-57

Major, René, 161

Malabou, Catherine, 91

Malinowski, Bronisław, 108, 110

Mandelstam, Nadezhda, 153

Mann, Thomas, 43-44, 350

Manzoni, Piero, 17, 20

Marcuse, Herbert, 3, 140

Marót, Károly, 131

Marton, Magda, 229-30

Marx, Karl, 67, 324

Mascarenhas, Helio, 146

Maslow, Abraham H., 354-55

Masson, Jeffrey M., 13, 16n2, 19n6,

Mátrai, László, 227-28

Matthews, Eric, 307-8

McCallum, David, 308, 314

Mérei, Ferenc, 190, 192-93, 196, 206n1, 20810, 212, 214, 220n15, 221, 223, 230-32

Mester, Sándor, $41 \mathrm{n} 3$

Mészáros, Judit, 138-39

Mikos, János, 30

Mogilner, Marina, 276

Moi, Toril, 56n3

Molnár, Imre, 209

Montaigne, Michel de, 171

Montesquieu, 109n2

Morantz-Sanchez, Regina, 302

Moravcsik, Ernő, 248

Moreau de Tours, Jacques-Joseph, 240n1

Morel, Bénédict Augustin, 240n1, 289

Moscovici, Serge, 48

Möbius, Paul, 240n1

Musil, Robert, 83

Müller-Braunschweig, Carl, 142-44 


\section{$\mathrm{N}$}

Nagy, Lajos, 119-20

Newlands, David, 13

Nonne, Max, 260

Nordau, Max, 240n1

\section{O}

Oláh, Gusztáv, 141n2, 245, 248-50

Olssen, Mark, 324

Oppenheim, Hermann, 68, 260

Oppolzer, Johann von, $247 \mathrm{n} 8$

Osipov, Viktor Petrovich, 285-86

\section{P}

Patai, Raphael (Rafael), 132

Pataki, Ferenc, 208, 211, 218, 221, 224$25,227-28$

Pavlov, Ivan, 32

Pawluch, Dorothy, 310, 312

Pelican, E.V., 279

Pellegrino, Eduardo, 146

Peter III (Pyotr Fyodorovich), 278

Petőfi, Sándor, 119-23, 133

Pick, Daniel, 114, 240n1

Pickersgill, Martyn, 330

Pinel, Philippe, 279-80, 313

Pirogov, Nikolay Ivanovich, 285

Pléh, Csaba, 210-12, 214

Polányi, Michael, 61

Pontalis, Jean-Bertrand, 113, 140

Popper, Péter, 226

Prince, Morton, 18

\section{R}

Rabelais, François, 15

Rabinow, Paul, 274, 288

Radó, Sándor, 73, 138, 169

Rákosi, Mátyás, 219, 220n16

Rancière, Jacques, 273

Rank, Otto, 98, 348

Ranschburg, Jenő, 226
Ranschburg, Pál, 28-29, 33, 188n3, 191n5, 226, 299

Reich, Wilhelm, 3, 82, 142-44, 148, 168, $170,355-56359,361$

Reik, Theodor, 156

Renner, Andreas, 275

Révész-Radó, Erzsébet, 53n1

Rickman, John, 61

Róheim, Géza, vi, 3, 4, 79, 93, 107-15, 119-33, 137, 139

Róheimné Leszik, Ilona (Ilonka), 126, 132

Róheimné Schultz, Leontine, 120, 126

Rohonyi, Charles, 124, 126, 131-32

Rose, Jacqueline, 156, 158

Rose, Nikolas, 170, 307, 325, 330

Rosenberg, Marshall B., 356-57, 363

Rosenfeld, Eva, 169

Roßbach, Julius, 267

Rossolimo, Grigorii Ivanovich, 299

Rotter, Lillián, 53n1

Rousseau, Jean-Jacques, 67, 111, 313

Rubinstein, Sergei, 222

\section{S}

Sachs, Hanns, 58

Sachs, Wulf, 155-59

Salgó, Jakab, 241n2, 243, 245-46

Sampson, Edward, 167, 178-79

Scheff, Thomas J., 311

Schell, Terry L. , 338

Schnell, János, 188n3, 190n4

Schwartzer, Ferenc, 243

Scott, James C., 295

Searle, John, 169

Sedgwick, Peter, 6, 321-24, 326

Segal, Hanna, 153, 346

Semyonov, Aleksandr, 276

Severn, Elisabeth ("R. N."), 31, 44n7

Severn, Margaret, 44

Shweder, Richard, 180

Simmel, Ernst, 67-68, 261

Skoda, Josef, $247 \mathrm{n} 8$

Spencer, Herbert, 256

Spielrein, Sabina, 101

Spitz, René, 347 
Spranger, Eduard, 265-66

Stalin, Joseph, 186n1, 205, 208n6, 220n16, 228n 22

Stanca, Dominic, 295

Stanton, Marton, 96

Stearn, Robert, 325-27

Stein, Fülöp, 247

Stekel, Wilhelm, 33, 42, 44, 46, 48, 345

Stepansky, Paul E., 349-50

Sullivan, Harry Stack, 346-47

Szapáry, Ferenc, 27

Szasz, Thomas S., 306, 308-9, 314-15, 328,335

Szász, Zoltán, 44, 125

Székács-Schönberger, István, 125-26

Székely, Zsigmond, 69

Székely-Kovács, Alice, see Bálint, Alice

Székely-Kovács, Olga, 61n11, 64, 70

Szinetár, Ernő, 44, 48

Szondi, Lipót (Leopold), 188n3, 190n4, 207

\section{$\mathrm{T}$}

Taylor, Charles, 172

Thatcher, Margaret, 323

Timashev, A.E, 279

Tisza, István, 125

Toulmin, Stephen, 171, 173-74, 178

Tours, J. Moreau de, 240n1

Trapeznikov, L. V., 285

Tylor, Edward, 107, 110

Tyrkov, Arcadii, 288

$\mathrm{U}$

Urbantschitsch, Rudolf von, 42

\section{V}

Varró, Grete, 68

Vay, Adelma, 27

Vay, Ödön, 27

Vészi, József, 41n2

Vianna, Helena, 145-46, 159, 161-63

Vikár, György, 197-200

Villela, Lucia, 160-62

Virchow, Rudolf, 247n8

Voloshinov, Valentin Nikolaevich, 154

Völgyesi, Ferenc, 31-33

\section{W}

Wagner, Lilla, 53n1

Wagner-Jauregg, Julius, 266

Wajdits, Lajos, 30

Wallerstein, Robert, 146, 160

Wallon, Henri, 190n4

Ward, Ivan, 14

Weiner, Leo, 68

Wells, Richard, 13, 16-17

Wertheimer, Max, 265

Westphal, Carl, 247n8

Widiger, Thomas A., 335

Winnicott, Donald, 346, 348

Withers, Rachel, 11-14, 16-17

Woolgar, Steve, 310-12

Wundt, Wilhelm, 180, 265

\section{$\mathrm{Z}$}

Zilahy, Lajos, 258

Zweig, Stefan, 44

Zsindely (Lazáry), Zsuzsanna, 256

Zsindely, Sándor, 256 
sy-sciences (psychology, psychiatry, psychoanalysis, pedagogy, criminology, special education, etc.) have been connected to politics in different ways since the early twentieth century. Here, in twenty-two essays, scholars address a variety of these intersections from a historical perspective.

The chapters include such diverse topics as the cultural history of psychoanalysis, the complicated relationship between psychoanalysis and the occult, and the struggles for dominance between the various schools of psychology. They show the ambivalent positions of the "psy" sciences in authoritarian regimes, revealing the role of psychology in legitimating and normalizing them on the one hand, and being exposed to the repression of dictatorships on the other.

The authors also discuss the ideological and political aspects of mental health and illness in Hungary, Germany, post-World War I Transylvania, and Russia. Other chapters describe the attempt by critical psychology to understand the production of academic, therapeutic, and everyday psychological knowledge in the context of the power relations of modern capitalist societies.

Psychology and Politics brings together an intriguing set of essays on the ever-ambivalent relationships of various psy-sciences to geopolitics and personal political commitments alike. Special attention is paid to conditions under repressive regimes (from the Russian Empire to Nazi Germany, and from Eastern European state socialism to military-dictatorship Brazil and apartheid South Africa), along with contexts of war or of anti-Semitic upheavals. A major strength of the collection lies also in the wealth of evocative primary material assembled here. The essays are moving, vivid, informative, and revelatory.

Dagmar Herzog, author of Cold War Freud: Psychoanalysis in an Age of Catastrophes

This rich collection of essays traces the complex interplay between the psychological sciences and politics in twentieth-century history. It provides a thought-provoking and sometimes unsettling account, from the direct implementation of policies to more indirect, hidden, and mediated forms of social, ideological, and cultural influence. Two things in particular make the book stand out: a geographical emphasis on the less discussed Eastern and Central European regions, and critically engaging with the topics of trauma, social injustice, and political-ethical responsibility in the history of psychoanalysis.

Tuomas Laine-Frigren, author of Searching for the Human Factor: Psychology, Power and Ideology in Hungary during the Early Kádár Period

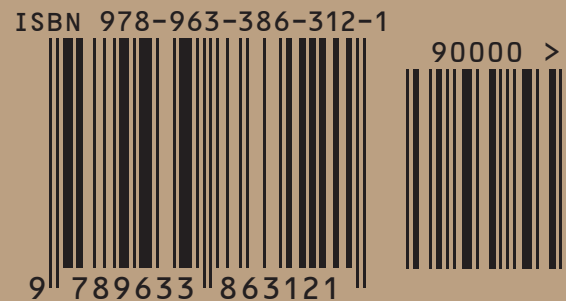

Central European University Press Budapest - New York

Sales and information: ceupress@press.ceu.edu Website: $h t t p: / / w w w . c e u p r e s s . c o m$ 